

\section{Faith-Based Organizations in Development Discourses and Practice}

Exploring faith-based organizations (FBOs) in current developmental discourses and practice, this book presents a selection of empirical in-depth case-studies of Christian FBOs and assesses the vital role credited to FBOs in current discourses on development.

Examining the engagement of FBOs with contemporary politics of development, the contributions stress the agency of FBOs in diverse contexts of development policy, both local and global. It is emphasised that FBOs constitute boundary agents and developmental entrepreneurs: they move between different discursive fields such as national and international development discourses, theological discourses, and their specific religious constituencies. By combining influxes from these different contexts, FBOs generate unique perspectives on development: they express alternative views on development and stress particular approaches anchored in their theological social ethics.

This book should be of interest to those researching FBOs and their interaction with international organizations, and to scholars working in the broader areas of religion and politics and politics and development.

Andreas Heuser is Professor for Extra-European Christianity at the University of Basel.

Jens Koehrsen is Professor of Religion and Economy at the University of Basel. 


\section{Routledge Studies in Religion and Politics \\ Edited by Jeffrey Haynes \\ London Metropolitan University, UK}

This series aims to publish high quality works on the topic of the resurgence of political forms of religion in both national and international contexts. This trend has been especially noticeable in the post-cold war era (that is, since the late 1980s). It has affected all the 'world religions' (including, Buddhism, Christianity, Hinduism, Islam, and Judaism) in various parts of the world (such as, the Americas, Europe, the Middle East and North Africa, South and Southeast Asia, and sub-Saharan Africa).

The series welcomes books that use a variety of approaches to the subject, drawing on scholarship from political science, international relations, security studies, and contemporary history.

Books in the series explore these religions, regions and topics both within and beyond the conventional domain of 'church-state' relations to include the impact of religion on politics, conflict and development, including the late Samuel Huntington's controversial - yet influential - thesis about 'clashing civilisations'.

In sum, the overall purpose of the book series is to provide a comprehensive survey of what is currently happening in relation to the interaction of religion and politics, both domestically and internationally, in relation to a variety of issues.

For more information about this series, please visit: www.routledge.com/ Routledge-Studies-in-Religion-and-Politics/book-series/RSRP

\section{Racialization, Islamophobia and Mistaken Identity}

The Sikh Experience

Jagbir Jhutti-Johal and Hardeep Singh

\section{Religion in the Era of Postsecularism}

Edited by Uchenna Okeja

\section{War and Religion in the Secular Age}

Faith and Interstate Armed Conflict Onset

Davis Brown

Faith-Based Organizations in Development Discourses and Practice Edited by Andreas Heuser and Jens Koehrsen

For more information about this series, please visit: https://www.routledge.com 


\title{
Faith-Based Organizations in Development Discourses and Practice
}

\author{
Edited by
}

Andreas Heuser and Jens Koehrsen 
First published 2020

by Routledge

2 Park Square, Milton Park, Abingdon, Oxon OX14 4RN

and by Routledge

52 Vanderbilt Avenue, New York, NY 10017

Routledge is an imprint of the Taylor \& Francis Group, an informa business

(C) 2020 selection and editorial matter, Andreas Heuser and Jens Koehrsen; individual chapters, the contributors

The right of Andreas Heuser and Jens Koehrsen to be identified as the authors of the editorial material, and of the authors for their individual chapters, has been asserted in accordance with sections 77 and 78 of the Copyright, Designs and Patents Act 1988.

The Open Access version of this book, available at www.taylorfrancis.com, has been made available under a Creative Commons Attribution-Non Commercial-No Derivatives 4.0 license.

Trademark notice: Product or corporate names may be trademarks or registered trademarks, and are used only for identification and explanation without intent to infringe.

British Library Cataloguing-in-Publication Data

A catalogue record for this book is available from the British Library

Library of Congress Cataloging-in-Publication Data

Names: Heuser, Andreas, 1961- editor. | Koehrsen, Jens, editor.

Title: Faith-based organizations in development discourses and practice / edited by Andreas Heuser and Jens Koehrsen.

Description: Abingdon, Oxon ; New York NY : Routledge, 2020.

Series: Routledge studies in religion and politics | Includes bibliographical references and index.

Identifiers: LCCN 2019036273 (print) | LCCN 2019036274 (ebook) | ISBN 9780367367565 (hardback) | ISBN 9780429351211 (ebook)

Subjects: LCSH: Religious institutions-Developing countries. Economic development-Religious aspects-Christianity. | Economic assistance-Developing countries. | Church and state-Developing countries.

Classification: LCC BR115.U6 F35 2020 (print) | LCC BR115.U6 (ebook) | DDC 361.7/5091724-de23

LC record available at https://lccn.loc.gov/2019036273

LC ebook record available at https://lccn.loc.gov/2019036274

ISBN: 978-0-367-36756-5 (hbk)

ISBN: 978-0-429-35121-1 (ebk)

Typeset in Times New Roman

by Apex CoVantage, LLC 


\section{Contents}

List of tables vi

List of contributors vii

Foreword ix

1 Beyond established boundaries: FBOs as developmental entrepreneurs

JENS KOEHRSEN AND ANDREAS HEUSER

2 From missionaries to ecumenical co-workers: a case study from Mission 21 in Kalimantan, Indonesia

CLAUDIA HOFFMANN

3 Mobilising evangelicals for development advocacy: politics and theology in the Micah Challenge campaign for the Millennium Development Goals

DENA FREEMAN

4 World Vision and 'Christian values' at the United Nations JEFFREY HAYNES

5 Giving and development: ethno-religious identities and 'holistic development' in Guyana

SINAH THERES KLOß

6 Contextualized development in post-genocide Rwanda: exploring the roles of Christian churches in development and reconciliation

CHRISTINE SCHLIESSER 


\section{Tables}

4.1 World Vision operating revenue, 2013-2015 89

4.2 Sustainable Development Goals: improved outcomes for children 97

4.3 World Vision's advocacy at the UN and at the country level in pursuit of child- and women-focused goals 98

5.1 Religious affiliations in Guyana, National Census $2012 \quad 124$ 


\section{Contributors}

\section{The editors}

Andreas Heuser is Professor for Extra-European Christianity at the University of Basel. His research covers mission history in Africa, African Instituted Churches (AIC) and the Pentecostal movement as well as migrant Christianity in Germany and Switzerland.

Jens Koehrsen is Professor of Religion and Economy at the University of Basel. His research interests include religion and sustainable development, social differentiation, low carbon transitions, sociological theory and qualitative research methods.

\section{The contributors}

Dena Freeman is Senior Visiting Fellow in the Department of Anthropology at the London School of Economics and Political Science. Her research interests include religion and development, globalisation, social justice, democracy and inequality.

Jeffrey Haynes is Emeritus Professor of Politics at London Metropolitan University. His research interests include religion and international relations, religious and development and religion and democratisation.

Claudia Hoffmann is a post-doc researcher for Extra-European Christianity at the Faculty of Theology in Basel, Switzerland,. Her research interests include hermeneutics of the stranger, religion and migration, history of religion and mission in Southeast Asia with a focus on Indonesia.

Sinah Theres Kloß is Research Associate at the Morphomata Center for Advanced Studies at the University of Cologne. Her research interests include the anthropology of religion, material culture studies, tattoo and dress, migration, and Caribbean Studies. 
Christine Schliesser is a lecturer in Systematic Theology/Ethics at Zurich University, a Research Fellow at the Chair for Historical Trauma and Transformation at Stellenbosch University and the scientific coordinator of the interfaculty research cooperation "Religious Conflicts and Coping Strategies" at Bern University. Her research interests include peace and reconciliation studies, religion and sustainable development, public theology and the theology and ethics of Dietrich Bonhoeffer. 


\section{Foreword}

This book is the outcome of the fellow programme of the Centre for Religion, Economy, and Politics which was hosted at the University of Basel. Over the course of a two-year research collaboration between scholars from different disciplines, we elaborated on "Religion and Development in the Global South". The focus of this endeavour was faith-based organizations and their entanglements with various, sometimes conflicting, discursive fields in diverse geographical and political arenas. Given its interdisciplinary character and the intensive exchanges at our meetings, this collaboration has offered new perspectives and insights to those participating: Dena Freeman, Jeffrey Haynes, Andreas Heuser, Sinah Kloss, Jens Koehrsen, Christine Schliesser, and Claudia Hoffmann. Undertaking the fellow programme and publishing this volume has only been possible due to the support from various institutions and colleagues. A special thanks goes to Claudia Hoffmann for the excellent organization of our activities: besides contributing to this project as a fellow, she facilitated the administrative coordination of the fellow programme. Moreover, Jana Füglistaler, Sven Holzer, and Vera Schaffer supported the organization of the fellow meetings, while Helen Gilroy, Anabel Da Pra, and Rahel Weber assisted the preparation of this volume. Moreover, we would like to thank our colleagues from the Centre for Religion, Economy, and Politics and the Faculty of Theology at the University of Basel for their cooperation in undertaking this fellow programme. Finally, several institutions have sponsored the activities of this fellow programme: University of Basel's Faculty of Theology, the Swiss University Conference, the Foundation for Basic Research in Human Sciences, and the Voluntary Academic Society Basel (Freiwillige Akademische Gesellschaft Basel). The Swiss National Science Foundation financed the final workshop of the fellow programme and the open-access publication of this volume. We are grateful for the support that enabled us to undertake this innovative research collaboration and believe that the outcome of this project substantially contributes to our academic understanding of faith-based organizations.

Jens Koehrsen and Andreas Heuser Basel, February 2019 


\section{Beyond established boundaries}

\section{FBOs as developmental entrepreneurs}

\section{Jens Koehrsen and Andreas Heuser}

Current discourses in development studies signal an almost provoking "religious turn" in development policy. The high impact of religious agency in the context of global development work shines through in a programmatic statement, launched at the "Evidence Summit", held in mid-2015 in Washington, DC. The timing of this multiparty conference, as well as the list of convenors and the range of participating organisations is revealing. High-profile representatives of the World Bank and important national development institutions, such as the U.S. Agency for International Development, the German Federal Ministry for Economic Cooperation and Development, and the UK Department for International Development, convened with representatives of religious institutions and faith-based development organisations (FBOs) during the passage period that prepared for a new agenda of sustainable development coined by the United Nations (UN) as Agenda 2030. They jointly published a policy paper that combines the key-terms in recent UN development strategies, namely, poverty eradication and sustainability. This common policy statement on "Religion and Sustainable Development: Building Partnerships to End Extreme Poverty", heralded the systematic inclusion of FBOs at large in development cooperation. The initial sentence in their "key findings and recommendations for action" states: "The question is no longer whether religion matters for development. . . The question now is: how to systematically include the potentials of religious organizations for development, and according to what principles and criteria?" (Joint Learning Initiative on Faith \& Local Communities 2015, p. 3).

The statement climaxes the new role of religion and FBOs in developmental geopolitics. In broad terms it testifies a re-narration of ideas that remained mostly undisputed in development theory and practice thus far. Over and above, development discourse was shaped by modernisation theory with its implicit assumptions about the negative impact of religion for development. By contrast, the statement cited above emphasises religious agency in international governance of development. The former approaches, which marginalised religion and faithbased institutions as hindrance to development, seem to be replaced by positions supporting the transformative potentials of religion (cf. Heist and Cnaan 2016; Heuser and Koehrsen 2020; Mtata 2013). While FBOs were formerly linked to "tabooed" themes in development studies, they are now identified as decisive 
agents of development initiatives in what some observers have recently termed the "religious turn" in development cooperation (Garling 2013; cf. Jahnel 2015).

This volume engages with the vital role credited to FBOs in current discourses on development. FBOs are social organisations with a development focus, based on values intrinsic to a specific religion. They usually relate to generic religious traditions of charity and dignity that inspire their particular theological social ethics. Yet, far from identifying FBOs as salvific porters of social visionary and praxis, this volume sketches both potentials and limits of FBOs in actual fields of development. Although few FBOs can claim an entangled history with development politics on global levels, they emerged as potent actors in the field of multilateral development policy on a broader scale from the 1990s. Against the backdrop of FBOs' increasing integration into international development circles, there is a need for empirically based, interdisciplinary research on these organisations (see also Carrette 2017; Carrette and Miall 2017). This volume provides an interdisciplinary analysis of FBOs in current development discourses.

The collection of case studies in this volume highlights the particularities of FBOs, their development concepts and activities in diverse geographical and political contexts. At the United Nations, depending on the survey, between well over half and up to three quarters of all FBOs have a Christian faith-background (cf. Beinlich and Braungart 2019; Berger 2003; Haynes 2013; Lehmann 2016, p. 35). This volume places a specific emphasis on Protestant FBOs. Forming a central strand of Christianity, Protestant FBOs represent the lion's share of Christian FBOs and constitute some of the most powerful among them. The focus on Protestant FBOs reflects not just the enduring but also the intensified developmental significance of these organisations. The surge of Protestant FBOs is a trend line in the present arena of development politics. With protestant newcomers appearing in FBO sectors at an almost constant rate, this trend line mirrors both the ongoing diversification of Protestant churches on a global scale and their growing share in global Christianity. It also reflects the economic potential of many Protestant churches that have developed into more affluent social actors than ever before (Barnett and Gross Stein 2012). The volume thus echoes the heavy weight of Protestant FBOs on the global scale of development cooperation.

Nevertheless, Protestant FBOs are not a homogenous block of development organisations. Although sharing a "family resemblance" due to common origins in the Reformation and post-Reformation era (Graf 2006), they are highly diverse: Protestantism constitutes a heterogeneous universe of manifold Protestant traditions which are often classified into evangelical-conservative, mainline, and nonorthodox strands. These strands have evolved their own development discourses and FBOs, potentially leading to substantial differences in faith-based development. This volume undertakes in-depth case studies on a variety of Protestant FBOs. We explore FBOs anchored in mainline Protestantism, such as Mission 21 from Switzerland and development wings of the Anglican Church and the Presbyterian Church in Rwanda. These are balanced by case studies on FBOs representing strands of evangelical Protestantism, commonly perceived as conservative in socio-political terms, such as World Vision and Micah Challenge. Moreover, this 
volume also features a case study on non-orthodox Protestantism by exploring the Adventist Development and Relief Agency (ADRA) in Guyana. As such, the sample illustrates the plurality of Protestant FBOs, thereby answering to the call "to work more consistently through the complexity of individual cases" (Jones and Petersen 2011, p. 1301). The case study approach provides surprising insights on differences and overlaps of their development approaches, as will be discussed in the following sections.

Studying the heterogeneous universe of Protestant FBOs, this volume reveals their ability to act as boundary agents: FBOs move between different discursive fields such as national and international development discourses, their specific religious constituencies, and theological discourses. By combining influxes from these different contexts, FBOs generate unique perspectives on development: anchored historically in a range of protestant traditions, they express alternative views on development. Thereby, FBOs have the capacity to become developmental entrepreneurs, shaping development discourses with their genuine concepts. The case study approach illustrates a comparative sighting of what may be termed (Protestant) theologies of development. In order to analyse heterogeneous types of FBOs, their development concepts and activities, this volume draws upon interdisciplinary research. It is the outcome of a research project in which scholars from anthropology, economics, political sciences/international relations, sociology, and theology have worked together for two years. The contributions have been produced in the context of the fellow programme "Religion and Development in the Global South" of the Centre for Religion, Economy and Politics between 2015 and 2017. The Centre is run by several Swiss universities, while this particular fellow research programme was located at the University of Basel's Faculty of Theology. The Swiss University Conference, Swiss National Science Foundation, Foundation for Basic Research in Human Sciences, and the Voluntary Academic Society Basel (Freiwillige Akademische Gesellschaft Basel) have financially supported this undertaking.

The studies apply different methodologies such as narrative and ethnographic interviews, participant observations, archival and web research, and content analysis. In the context of the fellow programme, the contributors have taken the challenge to actively engage with other academic disciplines. The close exchange between the researchers from various disciplines in numerous meetings and feedback processes has contributed to the exploration of the institutional plurality and outreach of FBOs as well as to venturing into different discursive fields of development at local, national, and international levels. Such close interdisciplinary collaboration points to a productive way of studying FBOs and creating awareness for their manifold dimensions (e.g. theological, political, social, legal). The research collaboration focused on the internal (re)organisation of development discourses of FBOs and their search for appropriate alignments with developmental geopolitics. As a result, this volume characterises the selected Protestant FBOs as boundary organisations, navigating diverse discourses and settings.

This introductory chapter is structured as follows: the next section briefly outlines the emergence of FBOs on the international development scene, placing an 
emphasis on historical conjunctures that pushed FBOs into the universe of developmental geopolitics. Based on the results from this volume's empirical case studies, the following section draws conclusions regarding the embeddedness of FBOs in different discursive fields and their potential to bridge these fields. The last two sections summarise the case studies and present avenues for future research.

\section{FBOs and developmental geopolitics: historical developments}

The breakthrough of FBOs in global arenas of development happened from the 1980s and particularly in the 1990s. Until then, FBOs were profiled in developmental arenas as part of the large sector of autonomous, non-governmental organisations (NGOs). This was the legacy of post - Second World War political taxation. Since its foundation FBOs were relating to the United Nations (Boehle 2010a, p. 278). However, their religious background - more precisely their Roman Catholic background (Lehmann 2016) - was not recognised as an identity marker. Rather, these FBOs were coined as "non-governmental organisations". The term first appeared in the 1950s in resolutions of the Economic and Social Council (ECOSOC), one of the major UN policy sections (Lehmann 2016). A quite unspecific referent in its original usage, "NGOs" referred to all kinds of intermediary organisations operating within the range of UN structures, including business enterprises (Stockmann 2016, p. 545). This did not change much until the 1990s. Like any other NGO, FBOs were located in civil society to represent a participatory model of social organisation mostly on the grassroots level. In the international architecture of development politics, NGOs gained importance gradually - and along with them, so did FBOs, albeit implicitly. Yet, they were catapulted into global governance systems particularly from the 1980s onwards. One causative factor of their emergence was the obvious incapability of state-organised development. This had led to the formation and relevance of civil society as the "third sector" between state governance and economic systems. A novel architecture supported a more strategic cooperation in global partnerships between states, multilateral organisations, and civil society (Korten 1990). This also created a "new opportunity structure" for religious actors, opening new avenues for their participation in international politics and development (BaumgartOchse 2019, p. 5). The recent discovery of NGOs was soon after categorised as the "NGOisation" of developmental geopolitics (Messner 1996). In this terrain of reconstruction, FBOs also became discernible as specific agents in development theory and praxis.

The growing awareness of FBOs in the tapestry of international development policy found momentum in two phases: the first phase that roughly stretches over the 1990s climaxed with the adoption of UN Millennium Development Goals (MDGs) in 2000; the second phase relates to the transition period that led to the implementation of Sustainable Development Goals (SDGs) in 2015.

The first phase saw a multisited effort to revisit the impact of "religion" in dynamics of social change and development. A paradigmatic shift in strategising 
development was taking shape. Previous policies were inclined to linear, material growth-based visions of development, and implicitly "religion" was either categorised as negligible or as a hindrance factor to development (Senghaas 1985; Menzel and Senghaas 1986). By consequence, in development circles, "little [was] known about the role of spirituality in the development process, and little or no guidance [was] given to development practitioners as to how to address spiritual issues, resulting in less effective and even damaging development efforts" (Beek 2000 , p. 38; brackets by authors). The ignorance about the social transformative potentials of religion diminished through coincidental proceedings in developmental geopolitics.

The most remarkable process was a joint initiative by the World Bank - headed by its former president James D. Wolfensohn - and religious organisations spearheaded by the then Anglican Archbishop of Canterbury George Carey. It resulted in the World Faiths Development Dialogue (WFDD) from 1998. Between 1998 and 2005 a vivid consultation process paid new attention to religion in development scenarios. Numerous FBOs were pushing the thematic cluster of religion and development (Haynes 2013; Rees 2011), accompanied by the World Bank department on Development Dialogue on Value and Ethics - founded in 2000 - the Bretton-Woods institutions of World Bank and International Monetary Fund (IMF) together with major national and international development agencies, and alongside various global religious players such as the World Council of Churches (WCC). These fresh impulses coincided with the implementation of UN Millennium Development Goals. Drawn up over the course of the 1990s as a joint endeavour in global development governance, the MDG formulae potentially envisaged the incorporation of religiously motivated actors in development activities. By such a radical turn in the agenda of development policy, the MDGs sought, amongst others, to cut poverty levels in half by 2015, and to consolidate development programmes especially around rural and grassroots as well as human rights - based projects. This vision was already profoundly established as the preferential option in the development work of FBOs for some time (Bornstein 2002). FBOs did not only support the adoption of this "longest standing paradigm that has ever emerged in developmental thinking" thus far, but lauded the MDGs (ACT Executive Committee 2013, p. 2; Boehle 2010a). Meanwhile, numerous publications from multidisciplinary angles indicated a widely shared interest in the connection between religion and development: FBOs became slowly more identifiable as social actors in their own right (Haynes 2007; Clarke 2008; Ter Haar and Wolfensohn 2011; Mtata 2013; Marshall 2001; Clarke 2013).

This prepared the ground for the second phase in the discovery of FBOs as genuine partners in international development politics around 2015. The symbolic date stands for the implementation of a 2030 Agenda for Sustainable Development. Agreed by 193 countries, the Sustainable Development Goals (SDGs) were envisaged by the international community as a decisive step into a "Great Global Transformation" (Nuscheler 2012, p. 390). In a move towards sustainable modes of production, consumption, and resource use, the SDGs form a set of 17 development goals, diversified into 169 targets. The agenda's preamble refers back to the 
ambitious MDG commitment to ending poverty: "Eradicating poverty in all its forms and dimensions, including extreme poverty, is the greatest global challenge and an indispensable requirement for sustainable development" (United Nations 2015, p. 1). Yet, the SDGs span an expanded range of issues. The "great transformation" anchors sustainability in conjunction with social and ecological justice, taking into account issues ranging from human rights and gender inequality to climate change.

The 2030 Agenda is characterised by a multistakeholder, participatory, and value-oriented approach to sustainable development. In this process a "newfound enthusiasm" on FBOs was stirred (Occhipinti 2015, p. 333). Attention is given to the organisational strengths of FBOs, their access to global and local networks coupled with management experiences of small-scale and large-scale projects. Additionally, their normative and spiritual expertise that becomes manifest in the fields of education, public welfare, and in conflict mediation is considered a constitutive element in a value-oriented agenda of sustainability (Boehle 2010b). The FBO orientation on basic needs and advocacy in the field of poverty eradication and ecology underscore the central goals of sustainable development. FBOs assume prestige as facilitators of public discourses on development and are seen as vehicles for trust-building relationships at the grassroots level. In the case of Christian FBOs, the social and moral capital can rely on long-standing, historic relationships between local partners in both northern and southern hemispheres. In the case of Muslim FBOs, research highlights their capacity for reaching otherwise unreachable populations at the grassroots level (Petersen 2012a, p. 137). Put together, FBOs currently attract the attention of national and international development cooperation. Roughly over the past two decades FBOs have helped in condensing novel concepts of development and in reviewing development agendas. Although still in the initial stages of realising the Agenda 2030, FBOs render coherence to ideas of sustainable development, intensifying grassroots levels of efficiency. Rainer Tetzlaff estimates that within this new global architecture of sustainability and poverty, FBOs can even "offer alternative paths of survival" (Tetzlaff 2015, p. 39).

Yet, a more sceptical note on the impact of FBOs on development structures cannot be overlooked. This may still be true in view of the "data-poor" humanitarian sector as such (Barnett and Gross Stein 2012, p. 9). Due to the limited empirical data, the FBO impact on development processes is almost impossible to establish at this stage. However, FBOs are widely considered to bring about "a more people-centred, transformative and sustainable development" (Jones and Petersen 2011, p. 1299). Furthermore, intending to improve the effectiveness of their developmental work, numerous FBOs are currently revising organisational structures along the principles of commercial firms. FBOs are becoming increasingly aware of the competitiveness in the development market (Hopgood and Vinjamuri 2012): if they fail to raise revenues, minimise costs, protect their reputation, and hire specialised staff, they cannot meet their development objectives. Alongside the supposedly strong personal dedication of FBO staff, and a motivated constituency, all such aspects point at FBOs as capable development 
actors. But, so far, empirical evidence thereof remains a desideratum in development studies (Stockmann 2016, pp. 471-481; Ware et al. 2016, p. 331). Additionally, FBOs are frequently confronted with the allegation of conducting proselytism and, in the case of Muslim FBOs, are sometimes even alleged of being linked to terror organisations (Petersen 2012a, pp. 135-136; Petersen 2012b, pp. 771-774). Moreover, in development circles the "newfound enthusiasm" for FBOs is coupled with a Janus-faced challenge: On the one side, political development agency is confronted with improving their "religious literacy"; the legacy of an implicit negligence of religion in modernisation approaches to development is still enduring. On the other side, numerous FBOs are challenged to improve their "development literacy" (Deutsche Gesellschaft für Internationale Zusammenarbeit/German Association for International Cooperation (GIZ) 2015 , p. 22f.). The case studies collected in this volume can help filling this lacuna. By and large they are stretching these two main phases around the formulation of MDGs and SDGs in which FBOs appeared on grand scale in development geopolitics.

\section{Crossing boundaries: findings from the case studies}

This volume explores how FBOs relate to the discursive fields in which they move: religious discourses of their specific Protestant constituencies, development discourses of international bodies, state agencies, and secular NGOs, as well as transnational theological discourses. Each of the FBOs investigated in this volume moves in a particular constellation of discourses that to some extent influences its development notions and activities. For instance, national political cultures in countries such as Guyana or Rwanda create specific contexts for the development activities of local FBOs, shaping their approaches to development, as will be discussed in the case studies by Kloß and Schliesser. Similarly, major sea-changes in transnational theological discourses on development are likely to affect the development approaches of those FBOs that are connected to these discourses, as will be shown in the case studies by Hoffmann and Freeman. However, FBOs are no passive recipients of their social environment: they may also try to shape prevalent development notions through activities directed towards its religious constituencies (see Freeman's study of the Micah Challenge Campaign in this volume) or international communities (see Haynes' study of World Vision in this volume).

Defining FBOs is challenging. We suggest that FBOs can best be described by their boundary-crossing character: they move beyond established lines. The following elaborations on the findings from the case studies in this volume are structured in terms of the boundary-crossing character of FBOs: They cross the boundaries between secular and religious organisations (subsection 1), denominational lines (subsection 2), and different development contexts and discourses (subsections 3-4). Therefore, they become boundary agents that mediate between different discourses (subsection 5). By combining influxes from different contexts, they generate unique perspectives on development and have the capacity to 
become developmental entrepreneurs (subsection 6). The following sections will discuss these characteristics of FBOs based on the case studies in this volume.

\section{Unique organisations}

FBOs are neither traditional religious organisations nor simply NGOs with a religious labelling. They constitute a unique type of organisation that combines characteristics of NGOs and religious organisations. The contributions to this volume show that FBOs share some elements with NGOs, while simultaneously cultivating characteristics that mark their faith-background and distinguish them from other NGOs in development work. There are opposing views on the particularities of FBOs in comparison to NGOs (Clarke and Ware 2015): On the one extreme are assessments that perceive FBOs as genuinely distinctive from NGOs, given that their worldviews and guiding values strongly differ from that of NGOs (cf. James 2009). On the other extreme, scholars speak of a false and arbitrary division between FBOs and NGOs, pointing towards their similarities in development practices and their shared origins in civil society (cf. Green et al. 2012; Carrette 2017; Ware et al. 2016, pp. 322-324). Hence, Ware et al. claim that "the dichotomy between FBOs and secular NGOs is rather artificial" (Ware et al. 2016, p. 322). The contributions in this volume find evidence for both positions, indicating that FBOs differ in some respects from NGOs while showing similarities in others.

FBOs share similar development goals and practices with NGOs, often strongly engaging in the provision of health services and education (Berger 2003; Green et al. 2012; Heist and Cnaan 2016; Lunn 2009; Marshall 2001; Ware et al. 2016). Against the backdrop of rising environmental concern, their activities also increasingly tackle climate change and environmental degradation (Glaab 2017; Glaab et al. 2019; Koehrsen 2018, 2020). Paralleling secular NGOs, the FBOs in this volume conduct projects on poverty alleviation, health, gender equality, education, peace etc. Their development activities match with the goals fixed in the international development agendas of the MDGs and SDGs. Moreover, in order to plan, organise, and conduct their projects, they frequently collaborate with secular NGOs and FBOs from various faith-backgrounds (see also Boehle 2010b). In particular, large FBOs often partner with organisations not committed to Christian faith and values. For instance, World Vision works with Islamic Relief and many UN agencies (see Haynes 2019 in this volume).

However, in many other aspects FBOs do differ from secular NGOs: their foundational philosophies, moral and cosmological orientations, and motivations often draw upon their specific faith-basis (see also Berger 2003; Clarke 2006; Jennings and Clarke 2008, p. 272). Moreover, FBOs are embedded in religious networks and receive their funding from religiously motivated donors (Berger 2003; Kirmani 2012; Ware et al. 2016). For instance, the FBO Mission 21 in this volume outlines in its mission statement that the "Gospel of Jesus Christ" and the "vision of the Kingdom of God" guide the organisation in its activities. Mission 21 works closely with local churches in the global south and forms part of 
a worldwide community of churches and missions organisations; in addition it is linked to the ecumenical movement of the World Council of Churches (WCC) and the Reformed Church in Switzerland (see Hoffmann 2019 in this volume). Other organisations form an integral part of single churches: the Adventist Development and Relief Agency, investigated in this volume, is strongly linked to the Seventh Day Adventist Church (see Kloß 2019 in this volume). Being related to religious networks and discourses, the FBOs in this volume subscribe to specific notions of development, distinct from secular concepts of development. Examples for these notions are "spiritual development", "holistic development", "transformational development", and "integral mission". FBOs evolve their own "theologies" of development. Thus, there is no systematic "theology of development" in sight. However, the development concepts of Christian FBOs outlined in this volume share a holistic vision of human wellbeing which prominently feature spiritual wellbeing and individual self-transformation (see, for instance, Kloß 2019 in this volume).

Another potential difference between FBOs and "secular" NGOs concerns the presumed tendency to proselytism. Proselytism consists in active efforts to convert others to a particular religion, confession, or ideology (Lynch and Schwarz 2016). FBOs are frequently subject to the allegation of proselytism. The prime motivation of FBOs, the argument goes, is to exert a religious hegemony by instrumentalizing development discourses and practises of charity. Historic episodes known primarily from Imperial mission politics in colonial India have nurtured the accusation of proselytism. The motif of distributing food against the promise to convert has layered down in accounts about the so-called "rice Christians" (Bauman 2008, pp. 71-100). Such practices remained exceptional and have been substantially delegitimised by contemporary mission societies (Becker 2015, pp. 338-342). As an expression of a rather marginal and controversial evangelistic praxis, the proselytism formula however still overshadows contemporary FBO praxis in actual development studies.

The allegation of proselytism has facilitated the "othering" of Christian FBOs in opposition to non-religious (or other religious) NGOs. In particular, Muslim FBOs (Petersen 2012a) and evangelical FBOs (Berger 2003, p. 17; Clarke 2006; Heist and Cnaan 2016; Lunn 2009, pp. 944-946) are frequently suspected of using development work as an instrument for gaining new followers. For instance, Pelkmans (2009) observes that evangelical groups in Kyrgyzstan use their development activity for proselytising aims: they adopt a development language to gain access to new missionary fields and disguise their conversion efforts by dressing them in the welcomed rhetoric of humanitarian development. Moreover, the evangelical FBO sector seems to be sensitised in special ways to donor policies. Evangelical donors supporting FBOs may tend to have an interest in proselytism and, accordingly, evaluate the organisation's legitimacy based on its effectiveness in spreading the given faith (Lister 2003). However, religious donors are not the only stakeholder group of evangelical FBOs. Other important stakeholders, such as governmental agencies, international institutions, secular donors and collaboration partners, have different interests and are likely to repudiate religious 
proselytism. Moving between these different settings, evangelical FBOs form their own critical agendas and do not necessarily follow their religious constituencies. Many evangelical NGOs, including the two evangelical organisations in this volume (World Vision and Micah Challenge), disavow proselytism. They agree to national ethical statements renouncing proselytism (Harriss 2014) and/or affirm the Code of Conduct of the International Red Cross (Thaut 2009).

This is to say that the generalizing criticism of FBO proselytism has to be critically reviewed. Just in view of Christian FBOs, the general assumption of proselytism neglects and denies its internal diversity (Lynch and Schwarz 2016; Thaut 2009). Although Christian FBOs will not expressly outrule the option of individuals to convert by their free choice, religious proselytism concerns only a share of the more evangelical FBO spectrum. The majority of Christian FBOs reject strategic proselytism and tend to identify with standards of secular humanitarianism (Thaut 2009). Although linked to a religious tradition, the primary mission of most FBOs is neither to enlarge the sphere of influence of a certain religion nor to disseminate specific religious doctrines. Thus, proselytism does not constitute a characteristic that could clearly distinguish FBOs from non-religious NGOs. Moreover, any effort to draw a sharp line between religious and secular FBOs on grounds of proselytism overlooks the normative bias in secular humanitarianism (Barnett and Gross Stein 2012) and does not reflect on the "role of religion in ostensibly non-religious organisations" (Jones and Petersen 2011, p. 1298). Turning the other way round, attributing the problem of proselytism solely to FBOs masks the prevalent "donor proselytism" (Lynch and Schwarz 2016) of secular (and religious) organisations spreading, for instance, concepts of liberal capitalism, efficiency, and sustainability (Fountain 2015). If proselytism is regarded as illegitimate, then this also concerns secular development agents.

In a similar vein, allegations of gender conservatism are sometimes voiced against FBOs. Among Christian FBOs, features of gender conservativism can be found in some evangelical FBOs while, arguably, FBOs with a historic background in mainline Christianity are engaging for gender equality (Agadjanian 2005). Therefore, gender conservatism cannot be upheld as a general characteristic of FBOs.

In total, FBOs cannot easily be attributed to one of the two categories "religious organisations" and "secular NGOs" (Clarke and Ware 2015, pp. 40f., 45f.): they form a category of their own that moves beyond the boundaries of religious/secular organisations - institutional in-betweens, located "between religious organisations and secular organisations" (Torry 2005, p. 117). FBOs involve elements from both worlds and constitute "a unique hybrid of religious beliefs and sociopolitical activism" (Berger 2003, p. 16). The hybridity metaphor leaves space for interpretation. Although it does not direct towards definitional clarity, it works with an assumption of FBO-distinctiveness in terrains of development. On the one side, it dispenses from drawing precise lines between religious and secular spheres; on the other side, it relates to the special symbolic resources available to FBOs for development work. The particular religious traditions of FBOs and their theological justification of "social engagement at large" gain attention. 
Moreover, there is a certain terminological range of how to define these organisations. FBOs are also labelled as "spiritual NGOs", arguably to avoid interpretive reductions to monotheistic interpretations of "faith". In this vein, the acronym RNGOs, or "religious NGOs", is the preferred terminology in contexts of the United Nations. In addition, FBOs are sometimes qualified as specific "faithbased development organisations", specifying the development wings of larger religious bodies such as churches. All these notions stress the religious dimension of these organisations, comprising particular worldviews and ethics. The contributions published here prioritise the term "faith-based organisations". It is from this vantage point of genuine religious worldviews and ethics that FBOs are motivated to create favourable conditions for a "good life". Following Julia Berger's definition of what she prefers to call "religious NGOs" represented at the UN, we consider FBOs as "formal organisations whose identity and mission are selfconsciously derived from the teachings of one or more religious or spiritual traditions and which operate on a non-profit, independent, voluntary basis to promote and realize collectively articulated ideas about the public good at the national or international level" (Berger 2003, p. 16).

\section{Internal diversity: beyond classical lines of separation}

Categorising FBOs as a unique type of organisation says little about their extensive internal diversity and the different types of FBOs (James 2009; Kirmani 2012). The enormous variety is due to their structures as well as their respective religious backgrounds. FBOs differ in their organisational and management cultures, in their access to budgets, and in their radius and focus of activity, amongst others. Some FBOs are resource-rich international organisations operating within transnational networks; others are small locally active FBOs, dedicated to onepurpose projects. The diffuse scenery is still more complex given the existence of global north and global south FBOs adapting to contextual policy requirements (Nuscheler 2012, p. 387).

It is challenging to provide insightful internal classifications of FBOs. Categorising FBOs based on their denominational background (e.g. evangelical vs. mainline Protestant) or their organisational type (e.g. churches vs. religious NGOs) barely allows for drawing conclusions on the intensity that their faith-background plays in their development agendas and practices.

This volume studies three organisational types of FBOs: development sections of churches, missionary organisations, and autonomous faith-based development organisations. Although missionary organisations and churches are traditionally related closer to the religious field and act according to its logics (e.g. seeking to spread their religious message), they are sometimes also strongly committed to development programmes (see also Öhlmann et al. 2016). The case study by Schliesser in this volume shows how Christian churches in Rwanda engage in improvements in health, poverty alleviation, education, and, in particular, conflict resolution. Hoffman's contribution underlines the historic involvement of missionary organisations related to mainline Protestantism in education and other 
welfare activities. Missionary organisations and churches have historically played a crucial role in providing welfare services (e.g. education, health services) in many countries of the global south as well as the global north such as the USA (Deneulin and Rakodi 2011; Heist and Cnaan 2016). Their approaches to development do not necessarily differ from religious NGOs. As such, classifying FBOs into churches, missionary organisations, and religious NGOs does not lead to clear categories, which would enable researchers to distinguish their development approaches.

Another way of categorising FBOs draws upon their denominational backgrounds. The selection in this volume comprises case studies of FBOs mainly from a Christian tradition. Within Christianity there is a diversity of FBOs, including, among others, Catholic (e.g. Catholic Relief Services, Caritas International, Misereor), Orthodox (e.g. International Orthodox Christian Charities), and Protestant FBOs. Our focus is on Protestant Christianity, including FBOs related to evangelical, mainline, and "non-orthodox" (Seventh Day Adventists Church) forms of Protestantism. Often lines are drawn between mainline and evangelical Protestantism, while attention has traditionally been focussed on mainline Protestantism (Clarke 2006). Both expressions of Protestantism are based on different theological traditions that have informed their endeavours in development work, resulting in dissimilar histories of involvement. While mainline Protestantism has a long history of engagement in development work and its FBOs are often related to the ecumenical movement, evangelicals with their traditional emphasis on personal development and salvation have engaged in this topic to a lesser extent. Therefore, one may assume that an FBO being either mainline Protestant or evangelical will determine its development agendas and activities: FBOs from a mainline Protestant background will have a higher propensity to engage with secular topics and focus on structural inequalities, whereas FBOs with an evangelical background stress individual development and avoid structural inequalities. However, this volume sheds a critical light on this assumption and provides an alternative perspective: while mainline Protestants engage in theological programmes, evangelical FBOs focus on structural topics. The cases of Mission 21 (see Hoffmann 2019 in this volume) and Micah Challenge (see Freeman 2019 in this volume) illustrate these tendencies. Although Mission 21 as a mainstream Protestant FBO has a long tradition of collaborating with secular development partners, it has recently extended its theological programmes and religious focus. By contrast, Micah Challenge is an evangelical FBO that places an emphasis on advocacy work. Its activities reflect a broader transformation of the development approaches within the evangelical Lausanne Movement, more precisely the evangelical "left", increasingly emphasising the socio-political responsibility of evangelical Christians at large.

These insights indicate that boundaries between evangelical and mainline FBOs are blurring and that both types of FBOs are coming closer to each other in terms of their development agendas. Consequently, the development approaches of evangelical and mainline FBOs cannot easily be distinguished based upon their denominational background: FBOs with an evangelical background may focus on 
topics that appeared originally to be dominated by mainline FBOs, while mainline FBOs expand their spiritual development work.

In total, categorising FBOs according to their organisational forms (e.g. churches vs. religious NGOs) and denominational backgrounds barely allows for raising conclusions about the way in which their faith-background influences their development agendas and activities. More insights are gained from classifications that specifically focus on FBOs and group them by their "religiousness" (cf. Clarke 2008; Sider and Unruh 2004). For instance, Sider and Unruh (2004) suggest a classification ranging from faith-permeated FBOs to quasisecular organisations. This categorization provides information about the degree of attachment to their religious circles. It, therefore, defines the extent to which the discourses of their religious constituencies may shape the development agendas of the given FBOs, as will be further discussed below.

\section{Flexibility and accommodation}

FBOs are sometimes stereotyped as stuck in their religious discourses, being solitary and divisive (cf. Kirmani 2012). While Heist and Cnaan (2016, p. 12f.) find that there is very limited data on the collaboration of FBOs, the contributions in this volume show that FBOs are highly collaborative organisations and have a strong ability to adapt to different (non-religious) contexts.

Each of the FBOs discussed here relates to a specific religious constituency and has its specific religious identity, involving particular theological concepts. However, this does not imply that these organisations remain stuck in their theological discourses and religious contexts: in order to fund, organise, and conduct development work, FBOs go beyond their religious networks and move in non-religious contexts that are sometimes even hostile towards religion (see also Clarke 2008, pp. 4-5; Glaab 2017; James 2009): here, they find it difficult to be heard if they stick to their religious arguments. As such, it is impossible for them to carry their Christian identity through in different contexts: "To survive they must adapt" (James 2009, p. 10).

We are surveying activities and trajectories of FBOs within complex discursive fields, characterised by diverse regional, national, and international development discourses. These fields are inhabited by numerous stakeholders with occasionally conflicting interests and demands: religious constituents, donors, international development organisations, nation-states, regional governments, and recipients of development activities. As FBOs strongly depend on their socio-cultural environment, they have to respond to these discourses and demands.

The FBOs that have been studied in this volume demonstrate a strong ability to adapt to different contexts and sometimes pragmatically deal with heterogeneous expectations. In particular, this becomes manifest in their use of language. FBOs use varying discourse styles with governments, secular NGOs, religious donors, and churches. In each context, they have to follow the given communication standards and must know what type of reasoning convinces the communication partner(s) (e.g. what appeals to secular donors and what appeals to 
churches?). This is, for instance, illustrated by World Vision which reserves a Protestant vocabulary for its religious constituency: using this vocabulary helps to maintain its relationships with its evangelical donor communities. However, in international development circles, World Vision abstains from employing religious language (see Haynes 2019 in this volume).

Another example of FBOs' strong ability to adapt to non-religious contexts is their development agendas. FBOs design their agendas in interaction with their sociocultural environment. International development agendas that have been fixed in the MDGs and SDGs form reference points for the FBOs in this volume: focussing on topics such as poverty alleviation, education, conflict resolution, and women's empowerment, the FBOs relate to the international development goals. As such, the FBOs studied in this volume refer to the SDGs. For instance, World Vision works on six SDGs (see Haynes 2019 in this volume): good health and wellbeing (SDG 3), quality education (SDG 4), gender equality (SDG 5), sustainable cities and communities (SDG 11), peace and justice, strong institutions (SDG 16), and partnerships for the goals (SDG 17). While it is of little surprise that large FBOs which engage at the level of the UN are committed to the SDGs, the contributions in this volume find that even smaller FBOs engage with the international development agenda. For instance, the Presbyterian Church of Rwanda (Église Presbytérienne au Rwanda) conducts projects related to various SDGs, as for instance, peace and justice (SG 16), quality education (SDG 4), and good health (SDG 3) (see Schliesser 2019 in this volume). Moreover, evangelical FBOs that have been stereotyped as focusing on charity and individual life improvement also move actively into the direction of the MDGs and SDGs and address structural development issues. For instance, the evangelical FBO Micah Challenge actively campaigns for political advocacy work among evangelicals to promote the MDGs (see Freeman 2019 in this volume).

FBOs relate to international development agendas, but still make their own choices in how they approach development and what development goals they prioritise. Setting these priorities also depends on the regional context in which they move. As such, in the context of post-genocide Rwanda, FBOs place an emphasis on reconciliation (see Schliesser 2019 in this volume), while FBOs operating in the Guyanese context of ethno-religious competition regard their development activities as a way of counteracting the influence of FBOs related to other ethnoreligious group (see Kloß 2019 in this volume).

In total, this volume highlights the flexibility of FBOs. In contrast to expectations that FBOs are stuck in their religious discourses, we find flexibility and a high ability to adapt their practices, processes and communications to different contexts (see also Koehrsen 2017b). Nevertheless, moving simultaneously in heterogeneous contexts, they evolve strategies that go beyond simple accommodation, as will be shown in the following section.

\section{Coping with heterogeneous discourses}

The involvement in heterogeneous contexts does not only require FBOs to be flexible, but also to evolve strategies for handling the occasionally conflicting 
demands. Apart from flexible adaptation these strategies also include active ventures to transform these contexts, reducing the tensions between their conflicting demands.

Being embedded in different discursive fields is not a particularity unique to FBOs. FBOs share this characteristic with other NGOs which also deal with diverse and sometimes conflicting discourses and demands. However, FBOs differ from other types of NGOs in that they also relate to theological discourses and have a religious constituency. Institutional memberships in umbrella organisations and associations, donor relationships, and denominational affiliations create stable institutional connections between FBOs and the particular religious discursive field. Being related to a wider faith community provides them with an extensive social network and access to financial and organisational resources, as is frequently highlighted (cf. Berger 2003; Ware et al. 2016). Berger, for instance, stresses that FBOs can mobilise vast networks of believers and religious organisations and, therefore, have an extensive local reach (Berger 2003). While academic contributions usually highlight the potentials of affiliations with religious networks, they disregard the challenges that these may create for these organisations. Connections to religious networks make the development work of FBOs all the more complex by adding extra demands and views, given that FBOs are accountable to their religious stakeholders. As their financial influx and legitimacy often depends on the engagement with these stakeholders and their discourses, FBOs have to underpin their faith dimension by linking their development notions and activities to these discourses (James 2009; James and Crooks 2009). For instance, religious donors may require FBOs to clarify their faith identity (cf. James 2009, pp. 10-11). This creates difficulties for FBOs in situations in which other types of stakeholders view parading the faith dimension as inappropriate. As such, the "religious" extra-demands may conflict with the expectations of international or national development discourses (e.g. secular donor institutions) or even constrain effective development activities (see also Bradley 2005; Clarke 2008, pp. 24-32). For instance, in the case of Micah Challenge, the evangelical constituency places a strong emphasis on personal development and salvation (see Freeman 2019 in this volume). This emphasis hinders effective advocacy work. However, Micah Challenge has to draw upon this constituency to pursue its goals.

Nevertheless, the strength of the connection to religious discursive fields differs between FBOs. Drawing upon Sider and Unruh's (2004) classification of FBOs, these organisations can be grouped by their "religiousness" and degree of involvement with religious discursive fields (see also Petersen 2012a). While faith-permeated organisations are strongly embedded in the religious discursive field of the given constituency, in the case of quasi-secular organisations there are little or no connections at all to a religious discursive field. In the first case, the given FBOs mostly move in their religious discursive fields, strongly shaping their development concepts, and barely participate in national or international development discourses. In contrast, in the latter case of FBOs as quasi-secular organisations, the impact of religious discourses on the development concepts of these organisations is low or absent. 
The FBOs that have been studied in this volume have maintained their connections to the religious discursive fields. At the same time, they are not embedded solely in these discourses, as they move simultaneously in other discourses. They constitute a type of FBO that balances its membership in different discursive fields. This concerns many, if not most, FBOs engaging in development work at a national or international scale.

The simultaneous participation in heterogeneous discursive fields can create tensions, as development concepts and expectations may differ between religious constituencies (e.g. spiritual development and poverty mitigation) and international development discourses (e.g. emphasis on sustainability). The case studies in this volume point towards different strategies of FBOs in handling their participation in heterogeneous discourses.

World Vision carefully balances potential tensions by flexibly adapting its use of language to each context, using more religious concepts for its religious donor constituency and abstaining from them in the field of international development (see Haynes 2019 in this volume). This is what Jeremy Carrette calls the "chameleon politics" of religion given that religion appears and disappears in the strategic processes of the UN (Carrette 2017). World Vision's strategy lends itself to FBOs that strongly participate in international development discourses and therefore must adjust to its logics while seeking to maintain their relationship to their religious constituency.

Micah Challenge, in contrast, chooses an entrepreneurial strategy (see Freeman 2019 in this volume): it endeavours to transform the religious discourse. Aspiring to establish advocacy work among its constituency, it seeks to bring the religious discourse of its constituency closer to the theological discourse on integral development and the international development discourse. If this undertaking is successful, it will decrease tensions between the discursive fields and place FBOs that move between them in a more comfortable situation. This strategy requires vast social networks and long-term efforts in persuading the given religious constituencies. At the same time, it is uncertain and potentially hazardous, as it runs the risk of failing due to inertia of the religious discourses or even breaking with the religious constituency.

In national contexts where "religion" is negatively connoted, FBOs may choose to deny affiliation with any religious discourse. For example, the Save Abee Foundation in Guyana neglects a religious affiliation and suggests that its Christian competitors have links to religion (see Kloß 2019 in this volume). Hence, neglecting and/or attributing connections to religious discourses may form a competitive strategy of FBOs in national development discourses marked by a negative perception of religion. Finally, other strategies include distancing from specific discourses. FBOs can appeal more strongly to their religious constituency and its discourses and distance themselves from national or international development discourses. Or they may, as described above, leave their religious background and the discourses related to it behind.

As the contributions in this volume show, FBOs develop strategies to handle their simultaneous participation in heterogeneous contexts. These strategies 
comprise balancing, adaptation, distancing, entrepreneurship, and denial. Depending on the heterogeneity of the discursive fields to which FBOs connect, there will be more or less pressure to develop such coping strategies. Often, FBOs may experience none or only marginal tensions. This is, for instance, shown by the case study on Rwanda where local religious organisations connect with their religious development concepts and resources to national development goals (see Schliesser 2019 in this volume).

Whenever FBOs move between heterogeneous discourses, they are not only likely to evolve abilities over time to manage the differences between them, but also to create a nexus that connects these discourses.

\section{Boundary agents}

Ware, Ware, and Clarke (Ware et al. 2016) point to the boundary-keeping role of FBOs. Nevertheless, their position in between the boundaries of different discursive fields also converts FBOs into boundary agents. They cross boundaries, balance different discourses, and intermediate with their activities and concepts between the heterogeneous discursive fields (cf. Boehle 2010a; Guston 1999). This becomes evident in their development notions which combine secular and religious elements. For instance, the holistic development concept of the Presbyterian Church of Rwanda brings religious and secular dimensions of development together, stressing the spiritual as well as the social, economic, intellectual, cultural, and ecological dimensions of life (see Schliesser 2019 in this volume). Members of FBOs in Guyana regard a pure focus on materiality as short-sighted (see Kloß 2019 in this volume). For this reason, they prefer "holistic development" which combines the material aspects of development with the idea of spiritual development ("spiritual wealth") as personal development. The latter contrasts material wealth, as it is conceptualised as a form of wealth that people can keep with them after death.

FBOs combine influxes from religious and secular discourses to their specific notions of development and feed these notions back in to the discourses. Thereby, their development notions become devices for connecting different discourses and stakeholder demands (cf. Koehrsen 2017a; Star and Griesemer 1989). Through their development concepts, they can create a nexus between religious constituencies and theology discourses, as well as international and national development discourses combining "religious literacy" and "development literacy". FBOs provide an intellectual and practical space for exchanges between religious and secular actors and concepts.

\section{Developmental entrepreneurship}

We consider FBOs as developmental entrepreneurs. FBOs should not be regarded as passive recipients of their socio-cultural environment. The need to cope with conflicting expectations does not exclude agency, but rather creates incentives and opportunities to actively shape discourses. Being embedded in different discursive 
fields, FBOs do not only strategically adapt themselves to these discourses, they also actively participate in them and seek to shape prevalent development concepts. They do so based on their development priorities and notions. Thereby, and in the sense of developmental entrepreneurship, they bring alternative approaches into ongoing development debates (see Tetzlaff 2015).

This becomes particularly evident in the cases of Micah Challenge and World Vision which endeavour to influence development discourses (see Freeman 2019 and Haynes 2019 in this volume). These organisations feed their concepts and priorities of development back into the discourses in which they move and shape these discourses. For instance, by pledging US $\$ 3$ billion to the programme on Global Strategy for Women's and Children's Health, World Vision contributes to the relative relevance of this development field and will have a stake in the projects related to this programme (see Haynes 2019 in this volume). Moreover, by organising side-events at the UN, World Vision promotes child-focussed goals in development work among government officials and UN entities. Micah Challenge, in contrast, seeks to shape the discourses of its evangelical constituency by promoting advocacy work together with a new evangelical theology (see Freeman).

FBOs also contribute to critical reflection in ongoing development debates. In particular, FBOs' connections to religious worldviews and discourses allow them to take a critical distance and act as watchdogs in international development debates. FBOs' religious values constitute normative standards on the basis of which they critically assess existing concepts of development and develop alternative ways of thinking about development (see also James 2009, p. 8; Deneulin and Rakodi 2011, p. 46). Thereby, they can provide "emancipation from current conventional development models" (Lunn 2009, p. 948). For instance, from the late 1960s, FBOs related to the WCC criticised the reduction of development to material wellbeing and effectively promoted more encompassing concepts (see Hoffmann 2019 in this volume; Marshall 2001): these take into account the human dimension of development ("human development"), considering social justice and the general quality of human life. Given their potential to bring in critical reflection and actively shape development discourses, FBOs can become developmental entrepreneurs that advance alternative perspectives on development. This becomes evident in the specific notions of development that the FBOs in this volume employ (e.g. "spiritual development", "holistic development") and which include spiritual dimensions of life usually disregarded by secular development actors.

\section{Outline of the volume}

The following paragraphs summarise the case studies ordered along their national or international focus: while the three case studies of the Christian FBOs, Mission 21 (Hoffmann), Micah Challenge (Freeman), and World Vision (Haynes), specifically address their involvement in international development discourses, two case studies on Rwanda (Schliesser) and Guyana (Kloß) highlight the impact of national discourses on FBOs' development notions and activities. 
Claudia Hoffmann's case study focusses on Basel's Mission 21. This organisation is strongly related to mainline Protestantism and has its roots in a mission agency (Basel Mission), founded in 1815 in Basel, Switzerland. From a development perspective, its beginnings as a missionary agency in the early 19th century bear some characteristics of a religious development organisation which facilitated its collaboration with secular organisations such as the state-run Swiss Agency for Development and Cooperation (SDC) from the mid-20th century. Hoffmann's contribution explores the ways in which Mission 21 has changed its approach to development and mission over time.

While the organisation's concept of mission widely remained stable over the course of time, its approach to development has been subject to significant transformations. Hoffmann situates these transformations within the context of the WCC changing debates around mission and development. Since the 1970s ecumenical development debates within the WCC have placed an emphasis on "human development" and the JPIC-trilogy "justice, peace, and the integrity of creation", rejecting the predominant, economically focussed development approaches of that time. As Mission 21 forms part of these changing discourses, these have implications for the organisation which increasingly stressed the importance of "justice" and "peace" in its communications. Moreover, while Mission 21 originally separated development and missionary activities and followed a technical development approach, it started to integrate both development and mission, and substituted the technical notion of development with a holistic concept of development. The changing focus in the development work also becomes evident in the rising theological focus: "For Mission 21 the classical development projects to reduce poverty and end hunger are "nice to have", but their centrepiece is the theological and cultural exchange" (Hoffmann 2019 in this volume). Instead of becoming more secular in the face of rising collaboration with state-run agencies, the FBO has even managed to extend the theological dimension of its development activities.

The case of Mission 21 shows how development notions within an FBO change over time and how these changes relate to the discursive contexts in which the FBO is moving (e.g. the WCC). Moreover, it illustrates how FBOs resist tendencies to turn into "secular" agencies of development by increasingly integrating the religious dimension within their development activities.

Similar to Hoffmann's study, Dena Freeman observes transformations within the discursive field of FBOs. However, in Freeman's contribution, the transformations refer to the evangelical field and are, partly, of a purposive nature. Freeman focusses on the evangelical campaign Micah Challenge and explores its endeavours to disseminate a new theology among its evangelical constituency that facilitates evangelical advocacy work.

Studying the evolution of evangelical development discourses, Freeman describes a gradual process of change towards a new theology of development: while evangelical Protestantism is originally marked by a strong focus on personal development and salvation, theologians such as René Padilla and Samuel Escobar sought to extend the traditional evangelical theology by bringing in the 
social dimension, integrating personal and social development. Inspired by Latin American theology of liberation, the new theology conceptualises structural inequalities as structural sin and redemption as a social affair. This approach came to be known as "transformational development" and "integral mission" within evangelical Christian circles. The Lausanne Conference in 1974 was "a key moment" in the discussion about integral mission: the Lausanne Covenant defines socio-political involvement as a duty of Christians. However, this aspect remained highly debated within evangelical Christianity. The discursive shift implied transformations in evangelical development work: similar to the aforementioned case of Mission 21, evangelical FBOs started to conceptualise their development work as a form of religious practice. Moreover, they increasingly focussed on small-scale projects with local churches. As the idea of transformational development became widespread in the following years among the evangelical constituency in the UK and Australia, some evangelical FBOs started to push for further changes and sought to establish political advocacy work as a feature of evangelical engagement. In 2001, Micah Network was founded as a network organisation of several evangelical FBOs with the aim of promoting the idea of integral mission in the evangelical world. Pursuing the promotion of evangelical advocacy work, from 2004 until 2015, Micah launched a transnational campaign that sought encouraging evangelicals to influence governments to fulfil the MDGs. This campaign was called Micah Challenge and aimed "to transform the church and to get it and its members to engage in popular advocacy and campaigning as part of the living out of their faith" (Freeman 2019). Yet, the analysis is also about the limits of such transformation endeavours. Although national campaigns were established in 41 countries, the overall campaign faced strong difficulties to mobilise national evangelical communities which related back to the premillennial dispensationalist theology of many evangelicals. Micah employed different strategies to overcome these difficulties by establishing new theological arguments, highlighting, for instance, the biblical nature of justice and the difference between politics and advocacy work. Nevertheless, the campaign concluded with mitigated results: its impact on the evangelical community was small and it led to little evangelical advocacy work as it did not manage to overcome barriers among religious constituencies regarding advocacy.

The study on Micah Challenge presents an intriguing case of purposive innovation within a religious tradition, exploring the potentials and limitations of steered transformations to render its own religious constituency more "developmentfriendly". However, the firmly established focus on personal salvation has, so far, impeded a comprehensive transformation. Therefore, the case illustrates the potential discrepancies between FBOs and their religious constituencies: within the evangelical field, the theological discourse of FBOs appears to differ significantly from the discourse of its constituencies. While both seek to influence each other, they remain based on partly separated theologies. The case also indicates that FBOs committed to work with their religious constituency remain, to some extent, relegated to the theological discourses of their constituencies. 
Interestingly, Freeman and Hoffmann observe similar transformations among evangelical and mainline Protestant FBOs, as the religious dimension becomes increasingly integrated into their development activities, switching from a material approach towards a holistic concept of development. In both cases, these changes relate to transformations in the theological discourses of their communities.

Paralleling the aforementioned cases, Jeffrey Haynes focusses on a Christian FBO involved in international development circles. In this case, however, the organisation is deeply involved in the world of international development, venturing to shape international and national development agendas. Haynes analyses the activities of World Vision, a large FBO with an evangelical background at the UN. World Vision developed from a small Christian-focussed FBO to a global player in the world of international development with an annual budget of approximately US \$1 billion. Today, the UN constitutes a key environment for this organisation to lobby its development concerns to international and national decision makers and the wider public. Its development concerns largely relate to the development outcomes for children and women - regardless of their faith - in the global south. Haynes studies the ways in which World Vision seeks to promote these concerns at the UN and sheds light on four of its strategies: (1) engagement with the SGDs (and MDGs) as a door-opener for cross-sectoral collaboration, (2) sponsoring of large UN programmes, (3) flexible adaptation of its vocabulary, and (4) co-organisation of side-events.

World Vision strongly engages with the SDGs. As described previously, the SDGs (and MDGs) facilitate the integration of FBOs into the world of international development, enabling cross-sectoral collaboration with NGOs, governmental, and international bodies such as the UN and its subunits. As the SDGs (and MDGs) provide a joint development agenda for various types of development actors (e.g. religious and non-religious NGOs, nation-states), engagement with them facilitates collaboration on the basis of shared goals in order to strategically build up partnerships and pool resources for higher development impacts. World Vision places an emphasis on 6 of the 17 SDGs, primarily relating to the domains of health, education, gender equality, sustainable communities, peace, and partnerships. To promote these goals, it uses vast funds to sponsor extensive UN programmes that fall into its development concerns: for instance, it has pledged US \$3 billion between 2016 and 2020 to the programme, Global Strategy for Women's and Children's Health. Investing vast sums into UN programmes, World Vision focusses a significant proportion of its financial resources on the UN to influence and accompany its development work. In the context of the UN, World Vision has built up strong partnerships with an extensive variety of governmental and non-governmental organisations that pursue similar development goals. Its multilingualism and ability to adapt to different social environments contribute to its capacity of building up networks with diverse types of development actors. Moving between the rather "secular" world of the UN and its Christian constituency, World Vision has learned to adapt to different contexts: it flexibly adjusts its language style to the given constituency, using a more Christianbased discourse style for its religious constituency and a secular discourse style 
when interacting with states and international bodies. Finally, an important strategy for World Vision to influence development discourses at the UN is the coorganisation of side-events which are activities organised outside the formal UN programme. Hosting side-events together with national representatives at the UN (e.g. Canada, Paraguay) and other NGOs, World Vision seeks to inform the development views and policies of government officials and UN entities. The events aim to underline the importance of child-focussed goals in development work, by, for instance, giving a voice to children from the global south. Haynes concludes that, by engaging in the United Nations, World Vision has the potential to positively influence international development outcomes.

By exploring the strategies of World Vision, this case illustrates the strong stance that FBOs - in this case, an FBO of evangelical origin - may take in international development discourses: FBOs may not only seek to influence the discourses of their specific religious constituencies or home countries, but also the very international development agendas which will shape the development activities of nation-states, NGOs, and regional authorities.

In contrast to the aforementioned studies that place emphasis on FBOs' embeddedness in international development discourses, the following two studies by Kloß and Schliesser focus on the activities of FBOs in specific national contexts.

Sinah Klo $\beta$ ' contribution analyses the development concepts of two FBOs from different faith backgrounds in Guyana: the Save Abee Foundation (SAF) and the Adventist Development and Relief Agency (ADRA). While ADRA is a transnational Christian FBO and forms part of the Seventh Day Adventists Church, SAF is a small NGO with a Hindu background that operates mostly in the rural areas of Guyana and was founded by a Guyanese Indian living today in the USA.

As activists of both organisations draw no clear lines between the "spiritual" and "secular" spheres of life, they perceive development in a holistic way. Although partly conceptualising it from a material angle - for instance, by regarding growth in the availability of material products as central indicator of "development" - and placing an emphasis in their activities on the improvement of physical infrastructures, health, and education, activists from both FBOs highlight the importance of spiritual development. Studying these organisations and their socio-cultural context through anthropological field work, Kloß places a specific focus on the way in which ethno-religious groups negotiate status through development activities. The organisations operate in a post-colonial context shaped by strong ethno-religious power struggles between "Indians" (often conceived of as Hindu or Muslim) and "Africans" (often conceived of as Christian) who compete over social status and the access to resources (e.g. funding for industries, political power). This competition shapes national development discourses and activities: while development work is often perceived as a strategy of influencing power-relations between the ethno-religious groups, faith-based organisations, in particular, are suspected of proselytism. For instance, the founder of SAF and other Hindu informants regard charitable work of Hindus as a necessary means to counteract the perceived Christian missionary activities, cloaked in the costume of charity. Furthermore, the "giving" and "taking" of development aid has strong connotations for local actors. 
As being labelled as "giver" or "receiver" of charitable work conveys unequal status to actors, the "giving" and "taking" of different ethno-religious groups informs the Guyanese fabric of ethno-religious hierarchies. For instance, fearing being labelled as "impoverished others" and "receivers" of development aid, communities in need may reject development aid of NGOs. In contrast, those operating in development NGOs (such as some of Kloß' informants from SAF), may proudly portray themselves as "givers". Therefore, in the specific context of Guyana, the development activities of FBOs are enmeshed in the complex status negotiations between ethno-religious groups: "Both organisations compete for status and negotiate power relations in the Guyanese community through practices of giving, taking, or rejecting" (Kloß 2019). Development becomes a means of contesting the power of the other ethno-religious groups, claiming status by "giving" and allowing members of their own group to "reject" charity from the "other". Thereby, Kloß' chapter highlights the ways in which national cultural discourses and power dynamics shape FBOs' approaches to development.

Christine Schliesser's contribution explores the involvement of Christian churches in conflict resolution in the context of Rwanda. Having experienced a devastating genocide perpetrated by parts of its own population, the country's government strives for reconciliation. Schliesser raises the question of how religious organisations contribute to reconciliation and thereby to the development of the country. To address this question, she explores the reconciliation activities of the Anglican Church, the Presbyterian Church, and a Pentecostal Church by means of semi-structured interviews.

The general development activities of the organisations in the study relate to international development goals such as the SDGs as their activities focus on health, poverty alleviation, and education. Furthermore, they draw upon the broader concept of holistic development, which seeks to address "all dimensions of life" and integrates material and spiritual development. However, operating within a country that is marked by strong reconciliation efforts, the churches perceive reconciliation as a crucial feature of development: "Development in Rwanda, as it is viewed by the churches, cannot be separated from reconciliation" (Schliesser 2019). Therefore, the Christian churches in this study launch their own reconciliation activities. These efforts comprise, among others, theological training camps for pastors to lead reconciliation programmes, the preaching of forgiveness, projects to build relationships between perpetrators and victims, and radio shows. For instance, by facilitating micro loans to perpetrators and victims, the Presbyterian Church encourages the creation of joint businesses. Interestingly, all of the three churches in the study run activities that bring perpetrators and victims on a regular basis together, thereby pursuing the creation of stable social ties between them.

Comparing the FBOs' activities with those of the government, Schliesser finds some differences: although there is a strong partnership between churches and government in reconciliation and developmental activities, FBOs have their own approach to reconciliation work. They follow a bottom-up approach, in contrast to the top-down approach of the government. Moreover, churches can contribute 
to reconciliation with specific resources that are not equally available to the government: they build strong social ties, provide emotional support, and bring in their specific religious dimensions through the Christian message of forgiveness, healing, and love. In sum, by stressing reconciliation, the religious organisations in the study relate their development activities to the specific national context of Rwanda, but they do so with their own abilities and concepts.

Paralleling Kloß' contribution, Schliesser addresses how FBOs deal with divisions between "ethnic" groups. Stressing the importance of reconciliation as a prerequisite for development, Schliesser's study illustrates how religious groups seek to build peace and overcome ethnic divisions. By contrast, in Kloß' study, the ongoing power struggles between ethno-religious groups thwart the development work of FBOs and drag their activities into the very fabric of these struggles: the FBOs themselves become part of the ongoing ethno-religious competition, participating in the reproduction of these divisions. Though the religious groups studied by Schliesser endeavour to create new bridges, similar dynamics to that of Kloß' study cannot be fully excluded: the expansion of heterogeneous Christian denominations might in the end involve the creation of new - faith-based - boundaries in Rwanda, substituting the old ethnic ones. Therefore, both studies refer to the twofold ability of FBOs to bridge as well as (re)produce divides. Whether and to what extent they bridge or (re)produce divides appears to depend, inter alia, on the national context: with active reconciliation policies in place, Rwanda enforces ethnic reconciliation, while perhaps opening space for the creation of new divides. The absence of similar policies in Guyana paired with active efforts of ethnic entrepreneurs to consolidate divides and the almost unquestioned everydayness of these divides creates a fertile ground for the reproduction of these boundaries by FBOs.

\section{Outlook}

FBOs have become a relevant player and in some regions even key players in international development (see also Heist and Cnaan 2016). They constitute a unique type of organisation that combines characteristics of NGOs and religious organisations and move between different discursive fields and contexts. Their ability to act effectively in heterogeneous contexts and flexibly adapt to these contexts allows FBOs to mediate between them. Therefore, FBOs are boundary agents: they can create discursive spaces for the exchange between different types of actors, particularly religious and non-religious actors, on development.

As FBOs are simultaneously enmeshed in heterogeneous contexts involving different discourses, they are sometimes confronted with conflicting demands and tensions. Handling these tensions is challenging. FBOs respond with different strategies to the multiple demands. These strategies may also involve active efforts to transform existing discourses and views on development. As such, their relationship with the heterogeneous contexts in which they move is reciprocal: on the one hand, FBOs are influenced by the contexts in which they move; on the other hand, they undertake ventures to proactively shape them and have an impact on development discourses. 
Moving within different contexts enables FBOs to generate alternative perspectives on development: the simultaneous involvement in religious and development discourses informs their development concepts. Based on these perspectives, they provide new impulses and critical reflections to ongoing development debates.

As FBOs are increasingly important players in international development, there is a need for more research on these organisations. Based on the insights of the case studies in this volume, research may address the complex relationship with the heterogeneous discursive fields in which they move. Aside from assessing how they handle the tensions resulting from their participation in these fields, studies could explore the specific capacities that result from their embeddedness in different fields for development work and where these capacities can provide advantages (e.g. advocacy work). Another instructive path of research could be to compare FBOs from different faith traditions. While this volume places an emphasis on Protestant FBOs, more research is needed on FBOs from other faith backgrounds. Comparing Protestant FBOs with other FBOs, it may turn out that the particularities that have been highlighted here - such as the involvement in heterogeneous contexts and flexibility - are especially pronounced among Protestant (or Christian) FBOs, whereas FBOs from other faith traditions show other particularities and capacities for development work. For instance, it is unclear whether Christian FBOs are more inclined to form boundary agents than other FBOs, as it is easier for them to connect to international development discourses due to their higher acceptance in these circles. Therefore, studies could explore how FBOs from non-Christian faith backgrounds connect to different discourses and what development notions they evolve in this interplay. Thereby, studies may determine whether these FBOs face other challenges when simultaneously engaging with the discourses of their religious constituencies and those of international development and whether they need to evolve alternative strategies to handle them, different to those of the Protestant FBOs examined in this volume.

\section{References}

ACT Executive Committee, 2013. The Changing Development Paradigm. An ACT Alliance Discussion Paper [online]. Available from: www.cws.org.nz/files/ChangingDevel opmentParadigmPaperACTAlliance.pdf [Accessed 3 April 2017].

Barnett, M., and Gross Stein, J., 2012. Introduction: The Secularization and Sanctification of Humanitarianism. In: M. Barnett and J. Stein, eds. Sacred Aid. Faith and Humanitarianism. Oxford: Oxford University Press.

Bauman, C.M., 2008. Christian Identity and Dalit Religion in Hindu India, 1868-1947. Grand Rapids, MI: Eerdmans.

Baumgart-Ochse, C., 2019. Religious NGOs at the United Nations: Polarizers or Mediators? In: C. Baumgart-Ochse and K.D. Wolf, eds. Religious NGOs at the United Nations. Polarizers or Mediators? Abingdon, Oxon, New York, NY: Routledge, 1-25.

Becker, J., 2015. Conversio im Wandel. Basler Missionare zwischen Europa und Südindien und die Ausbildung einer Kontaktreligiosität, 1834-1860. Göttingen, Bristol, CT: Vandenhoeck \& Ruprecht Gm. 
Beek, K.A. ver, 2000. Spirituality. A Development Taboo. Development in Practice, 10 (1), 31-43.

Beinlich, A.-K., and Braungart, C., 2019. Religions NGOs at the UN. A Quantitative Overview. In: C. Baumgart-Ochse and K.D. Wolf, eds. Religious NGOs at the United Nations. Polarizers or Mediators? Abingdon, Oxon, New York, NY: Routledge, 26-46.

Berger, J., 2003. Religious Non-Governmental Organisations: An Exploratory Analysis. Voluntas: International Journal of Voluntary and Nonprofit Organisations, 14 (1), 15-39.

Boehle, J., 2010a. Religious NGOs at the UN and the Millennium Development Goals: An Introduction. Global Change, Peace \& Security, 22 (3), 275-296.

Boehle, J., 2010b. The UN System and Religious Actors in the Context of Global Change. CrossCurrents, 60 (3), 383-401.

Bornstein, E., 2002. Developing Faith: Theologies of Economic Development in Zimbabwe. Journal of Religion in Africa, 32 (1), 4-31.

Bradley, T., 2005. Does Compassion Bring Results? A Critical Perspective on Faith and Development. Culture and Religion, 6 (3), 337-351.

Carrette, J., 2017. Introduction: Religion, the United Nations and Institutional Process. In: J. Carrette and H. Miall, eds. Religion, NGOs and the United Nations: Visible and Invisible Actors in Power. Los Angeles, CA: Bloomsbury Publishing, 1-17.

Carrette, J., and Miall, H., eds., 2017. Religion, NGOs and the United Nations: Visible and Invisible Actors in Power. Los Angeles, CA: Bloomsbury Publishing.

Clarke, G., 2006. Faith Matters: Faith-Based Organisations, Civil Society and International Development. Journal of International Development, 18 (6), 835-848.

Clarke, G., 2008. Faith-Based Organisations and International Development. An Overview. In: G. Clarke and M. Jennings, eds. Development, Civil Society and Faith-Based Organisations. Bridging the Sacred and the Secular. Basingstoke, Hampshire: Palgrave Macmillan, 17-45.

Clarke, G., 2013. The Perils of Entanglement: Bilateral Donors, Faith-Based Organisations and International Development. In: G. Carbonnier, M. Kartas, and K.T. Silva, eds. International Development Policy: Religion and Development. London: Palgrave Macmillan UK, 65-78.

Clarke, M., and Ware, V.-A., 2015. Understanding Faith-Based Organisations: How FBOs are Contrasted with NGOs in International Development Literature. Progress in Development Studies, 15 (1), 37-48.

Deneulin, S., and Rakodi, C., 2011. Revisiting Religion: Development Studies Thirty Years On. World Development, 39 (1), 45-54. Available from: www.sciencedirect.com/ science/article/pii/S0305750X10001269.

Deutsche Gesellschaft für Internationale Zusammenarbeit/German Association for International Cooperation (GIZ), 2015. Staus-Quo Bericht: Religion und Entwicklung [online]. Available from: www.giz.de/fachexpertise/downloads/giz2015-de-status-quo-bericht. pdf.pdf [Accessed 3 April 2017].

Fountain, P., 2015. Proselytizing Development. In: E. Tomalin, ed. The Routledge Handbook of Religions and Global Development. London, New York, NY: Routledge, 80-97.

Freeman, D., 2019. Mobilising Evangelicals for Development Advocacy. Politics and Theology in the Micah Challenge Campaign for the Millennium Development Goals. In: J. Koehrsen and A. Heuser, eds. Faith Based Organisations in Development Discourses and Practice. London: Routledge.

Garling, S., 2013. Vom Störfaktor zum Operator. Religion im Diskurs der Entwicklungszusammenarbeit. Wiesbaden: Springer VS. 
Glaab, K., 2017. A Climate for Justice? Faith-Based Advocacy on Climate Change at the United Nations. Globalizations, 13 (4), 1-15.

Glaab, K., Fuchs, D., and Friedrich, J., 2019. Religious NGOs at the UNFCCC: A Specific Contribution to Global Climate Politics. In: C. Baumgart-Ochse and K.D. Wolf, eds. Religious NGOs at the United Nations. Polarizers or Mediators? Abingdon, Oxon, New York, NY: Routledge, 47-63.

Graf, F.W., 2006. Der Protestantismus. Geschichte und Gegenwart. München: Beck.

Green, M., Mercer, C., and Mesaki, S., 2012. Faith in Forms. Civil Society Evangelism and Development in Tanzania. Development in Practice, 22 (5-6), 721-734.

Guston, D.H., 1999. Stabilizing the Boundary between US Politics and Science. The Role of the Office of Technology Transfer as a Boundary Organisation. London.

Harriss, J., 2014. Proselytism and Canadian NGOs. Editor's Note. Canadian Journal of Development Studies/Revue Canadienne d'études du Dévelopment, 35 (3), 480-482.

Haynes, J., 2007. Religion and Development. Conflict or Cooperation? Basingstoke et al.: Palgrave Macmillan.

Haynes, J., 2013. Faith-Based Organisations at the United Nations. 2013/70. Florence: European University Institute.

Haynes, J., 2019. World Vision and 'Christian values' at the United Nations. In: J. Koehrsen and A. Heuser, eds. Faith Based Organisations in Development Discourses and Practice. London: Routledge.

Heist, D., and Cnaan, R., 2016. Faith-Based International Development Work. A Review. Religions, 7 (3), 19.

Heuser, A., and Koehrsen, J., eds., 2020. Does Religion Make a Difference? Religious NGOs in International Development Work. Baden-Baden/Zürich: Nomos.

Hoffmann, C., 2019. From Missionaries to Ecumenical Co-Workers. A Case Study from Mission 21 in Kalimantan, Indonesia. In: J. Koehrsen and A. Heuser, eds. Faith Based Organisations in Development Discourses and Practice. London: Routledge.

Hopgood, S., and Vinjamuri, L., 2012. Faith in Markets. In: M. Barnett and J. Stein, eds. Sacred Aid. Faith and Humanitarianism. Oxford: Oxford University Press.

Jahnel, C., 2015. 'Entwicklung': ein säkulares Heilsversprechen? Religion und Entwicklung post-säkular denken und interpretieren. Berliner Theologische Zeitschrift, 32 (2), 319-342.

James, R., 2009. What is Distinctive about FBOs? [online]. International NGO Training and Research Centre (INTRAC). Available from: http://dspace.africaportal.org/jspui/ bitstream/123456789/24075/1/What\%20is\%20distinctive\%20about\%20FBOs.pdf?1 [Accessed 10 June 2017].

James, R., and Crooks, B., 2009. Faith-Based Organisational Development (OD) with Churches in Malawi [online]. International NGOTraining and Research Centre(INTRAC). Available from: http://dspace.africaportal.org/jspui/bitstream/123456789/26272/1/ Praxis\%20Note\%2047\%20-\%20Faith\%20and\%20organisational\%20development. pdf?1 [Accessed 10 June 2017].

Jennings, M., and Clarke, G., 2008. Conclusion. Faith and Development - of EthnoSeparatism, Multiculturalism and Religious Partitioning? In: G. Clarke and M. Jennings, eds. Development, Civil Society and Faith-Based Organisations. Bridging the Sacred and the Secular. Basingstoke, Hampshire: Palgrave Macmillan, 260-274.

Joint Learning Initiative on Faith \& Local Communities, 2015. Religion \& Sustainable Development: Building Partnerships to End Extreme Poverty [online]. Available from: https://jliflc.com/resources/key-findings-recommendations/ [Accessed 20 June 2018]. 
Jones, B., and Petersen, M.J., 2011. Instrumental, Narrow, Normative? Reviewing Recent Work on Religion and Development. Third World Quarterly, 32 (7), 1291-1306.

Kirmani, N., 2012. The Role of Religious Values and Beliefs in Charitable and Development Organisations in Karachi and Sindh, Pakistan. Development in Practice, 22 (5-6), 735-748.

Kloß, S.T., 2019. Giving and Development. Ethno-Religious Identities and 'Holistic Development' in Guyana. In: J. Koehrsen and A. Heuser, eds. Faith Based Organisations in Development Discourses and Practice. London: Routledge.

Koehrsen, J., 2017a. Boundary Bridging Arrangements: A Boundary Work Approach to Local Energy Transitions. Sustainability, 9 (424).

Koehrsen, J., 2017b. When Sects Become Middle Class. Impression Management among Middle-Class Pentecostals in Argentina. Sociology of Religion, 78 (3), 318-339.

Koehrsen, J., 2018. Religious Agency in Sustainability Transitions: Between Experimentation, Upscaling, and Regime Support. Environmental Innovation and Societal Transitions, 27, 4-15.

Koehrsen, J., 2020. Muslim NGOs and the Quest for Environmental Sustainability. In: A. Heuser and J. Koehrsen, eds. Does Religion make a Difference? Religious NGOs in International Development Work. Baden-Baden/Zürich: Nomos, forthcoming.

Korten, D.C., 1990. Getting to the 21st Century. Voluntary Action and the Global Agenda. West Hartford, CT: Kumarian Press.

Lehmann, K., 2016. Religious NGOs in International Relations. The Construction of 'the Religious' and 'the Secular'. London, New York, NY: Routledge.

Lister, S., 2003. NGO Legitimacy: Technical Issue or Social Construct? Critique of Anthropology, 23 (2), 175-192.

Lunn, J., 2009. The Role of Religion, Spirituality and Faith in Development: A Critical Theory Approach. Third World Quarterly, 30 (5), 937-951.

Lynch, C., and Schwarz, T.B., 2016. Humanitarianism's Proselytism Problem. International Studies Quarterly, 60 (4), 636-646.

Marshall, K., 2001. Development and Religion. A Different Lens on Development Debates. Peabody Journal of Education, 76 (3-4), 339-375.

Menzel, U., and Senghaas, D., 1986. Europas Entwicklung und die Dritte Welt. Eine Bestandsaufnahme. 1st ed. Frankfurt am Main: Suhrkamp.

Messner, D., 1996. Politik im Wandel. NGOs in der Irrelevanzfalle oder NGOisierung der (Welt-)Politik? Die NGOisierung der (Welt-)Politik? In: Friedrich-Ebert-Stiftung, ed. Globale Trends und internationale Zivilgesellschaft oder: die NGOisierung der (Welt-) Politik? Bonn: Dietz, 11-38.

Mtata, K., 2013. Religion. Help or Hindrance to Development? Leipzig: Evangelische Verlagsanstalt.

Nuscheler, F., 2012. Lern- und Arbeitsbuch Entwicklungspolitik: Eine grundlegende Einführung in die zentralen entwicklungspolitischen Themenfelder Globalisierung, Staatsversagen, Armut und Hunger, Bevölkerung und Migration, Wirtschaft und Umwelt. 7th ed. Bonn: Dietz.

Occhipinti, L.A., 2015. Faith-Based Organisations and Development. In: E. Tomalin, ed. The Routledge Handbook of Religions and Global Development. London, New York, NY: Routledge, 331-345.

Öhlmann, P., Frost, M.-L., and Gräb, W., 2016. African Initiated Churches' Potential as Development Actors. HTS Teologiese Studies/Theological Studies, 72 (4).

Pelkmans, M., 2009. The "Transparency" of Christian Proselytizing in Kyrgyzstan. Anthropological Quarterly, 82 (2), 423-445. 
Petersen, M.J., 2012a. Islamizing Aid. Transnational Muslim NGOs after 9.11. Voluntas: International Journal of Voluntary and Nonprofit Organizations, 23 (1), 126-155.

Petersen, M.J., 2012b. Trajectories of Transnational Muslim NGOs. Development in Practice, 22 (5-6), 763-778.

Rees, J.A., 2011. Religion in International Politics and Development. The World Bank and Faith Institutions. Cheltenham: Edward Elgar Publishing Ltd.

Schliesser, C., 2019. Contextualized Development in Post-Genocide Rwanda. Exploring the Roles of Christian Churches in Development and Reconciliation. In: J. Koehrsen and A. Heuser, eds. Faith Based Organisations in Development Discourses and Practice. London: Routledge.

Senghaas, D., 1985. The European Experience. A Historical Critique of Development Theory. Leamington Spa: Berg.

Sider, R.J., and Unruh, H.R., 2004. Typology of Religious Characteristics of Social Service and Educational Organisations and Programs. Nonprofit and Voluntary Sector Quarterly, 33 (1), 109-134.

Star, S.L., and Griesemer, J.R., 1989. Institutional Ecology, 'Translations' and Boundary Objects. Amateurs and Professionals in Berkeley's Museum of Vertebrate Zoology, 1907-39. Social Studies of Science, 19 (3), 387-420.

Stockmann, R., 2016. Entwicklungsstrategien und Entwicklungszusammenarbeit. In: R. Stockmann, U. Menzel, and F. Nuscheler, eds. Entwicklungspolitik: Theorien Probleme - Strategien. Berlin, Boston, MA: De Gruyter, 424-615.

Ter Haar, G., and Wolfensohn, J.D., 2011. Religion and Development. Ways of Transforming the World. London: Hurst \& Co.

Tetzlaff, R., 2015. Political Architecture of Poverty: On Changing Patterns of 'African Identity'. In: A. Heuser, ed. Pastures of Plenty. Tracing Religio-Scapes of Prosperity Gospel in Africa and Beyond. Frankfurt am Main: Peter Lang Edition, 33-48.

Thaut, L.C., 2009. The Role of Faith in Christian Faith-Based Humanitarian Agencies. Constructing the Taxonomy. Voluntas: International Journal of Voluntary and Nonprofit Organizations, 20 (4), 319-350.

Torry, M., 2005. Managing God's Business. Religious and Faith-Based Organisations and their Management. 1st ed. Aldershot, Hants, Burlington, VT: Ashgate.

United Nations, 2015. Resolution Adopted by the General Assembly on 25 September 2015 [online]. Available from: www.un.org/ga/search/view_doc.asp?symbol=A/ RES/70/1\&Lang=E [Accessed 20 June 2018].

Ware, V.-A., Ware, A., and Clarke, M., 2016. Domains of Faith Impact: How "Faith" is Perceived to Shape Faith-Based International Development Organisations. Development in Practice, 26 (3), 321-333. 


\title{
2 From missionaries to ecumenical co-workers
}

\author{
A case study from Mission \\ 21 in Kalimantan, Indonesia
}

Claudia Hoffmann

\section{Introduction}

Mission 21, based in Basel, Switzerland, emerged through the union of several missionary organisations - Basel Mission is the best known amongst them - and was officially founded on 1 January 2001. Mission 21 sees its key tasks today in reduction of poverty, health care, agriculture, fair trade, education, the advancement of peace, the empowerment of women and gender equality. Coincidentally, the eight Millennium Development Goals (MDGs) were formulated around the same time, in September 2000, at the United Nations headquarters in New York by world leaders, "committing their nations to a new global partnership to reduce extreme poverty and setting out a series of time-bound targets" (United Nations 2016). The aims and goals of Mission 21 are therefore very similar to the agenda of secular development agencies trying to achieve the MDGs. Despite this similarity to secular development organisations, Mission 21 is very keen to show the continuity between their work nowadays and their initial history in the early 19th century. Although there have been several considerable frictions, particularly during the second half of the 20th century, their profile did not substantially change.

This mission organisation had to come across with changes, not only recently in the early 2000s, but also during the 1950s and in the 1960s Basel Mission had to deal with several frictions that affected their work and self-concept. This interesting time of transition to post-colonialism constitutes an underestimated period in the history of Christianity in the 20th century. During these years a paradigmatic shift occurs in Mission history: it is the time where the international missionary movement transformed, the ecumenical movement was differentiated, and independent - later called contextual - theologies from the South joined forces (Heuser 2016). The decolonisation in the 1960s forced missionary agencies to define themselves in a new way. In almost every country in the world, local autonomous churches emerged. The relationship between these churches and the mission organisations in Europe and USA had to be redefined. During the World Mission conference in Bangkok at the turn of 1972/1973, a proposal was made for a temporary moratorium on sending missionaries and money from the North to Africa, Asia and Latin America (World Council of Churches 2016b). The moratorium was never really accepted yet had an important impact on the self-concept of 
mission organisations and also on the purpose and meaning of mission. Craig Ott and Stephen Strauss, both professors of intercultural studies and mission, stress in their mission book that "In the 1960s the ecumenical movement proclaimed, that the age of 'missions' was thus passed. The age of 'mission' had come ..." (Ott et al. 2010, pp. 218-219). Thus, the sending of missionaries to distant and so called "unreached" peoples should stop and every church should become a mission church in its own locale. The age of real ecumenism began. Instead of missionaries, fraternal co-workers ${ }^{1}$ were needed in the newly established churches in the South.

In Basel Mission, the whole process of change in the understanding of missionaries began only in the 1970 s yet much earlier than in other places: the selfidentification of missionaries changed dramatically due to the eviction of all missionaries from China during the years after Mao Zedong's seizure of power from 1949-1952 (Jenkins 1998, pp. 21-22). This experience was a shock for Basel Mission; they no longer felt welcome in the missionary territories. After the missionary seminary in Basel was closed in 1954, Basel Mission decided to send out missionaries only on demand of their partner churches. ${ }^{2}$ Basel Mission had to redefine itself. The notion of "development" and how evangelisation and diaconia are linked together played a significant role in this redefinition process.

The aim of this chapter is to investigate the notion, implications and activities of development within Basel Mission/Mission 21, coming from a purely missionary agency and heading to a faith-based development organisation. ${ }^{3}$ How did they change over time? Mission 21 sees its key tasks today as working in the areas of poverty reduction, health care, agriculture, fair trade, education, the advancement of peace, the empowerment of women and gender equality. Despite all the frictions described above, the emphasis on continuity between the work in the early days of Basel Mission and the work of Mission 21 today will be explained. I will answer these questions through a comparative analysis of two projects or programmes of Mission 21 in Kalimantan, Indonesia. The first project is the Farming Centre in Tumbang Lahang which was opened in 1955, right after the China disaster, and closed in 2011. The second project is called "Empowerment of Basic Groups" and was implemented in 2015, when the new Sustainable Development Goals (SDG) were formulated. Furthermore, this contribution deals with the fact that mission organisations fit within the definition of "invisible NGOs" in the field of development (Clarke 2006, p. 843). Exploring the project work of Mission 21 helps to show the "added value" of mission organisations in development work that is assumed by several researchers (James 2011; Clarke 2012b). The case illustrates that faithbased organisations (FBOs) can become "development entrepreneurs" (Koehrsen and Heuser 2019 in this volume) by assuming critical positions towards prevalent development concepts and suggesting alternative notions of development.

\section{Mission organisations as "invisible NGOs"}

Generally speaking, the role of mission organisations in development co-operation has been ignored. In development discourses they have long been regarded as 
suspicious organisations by the development sector: mission organisations save souls and proselytise and are therefore not allowed into the development sector (Fountain 2015, pp. 89-90). However, in mainstream Christian teaching, mission is understood as "a continuation of Jesus' mission of service rooted in 'love', which itself was entrusted to his disciples whom He had sent out to share His Good News". The roots of mission seem to be quite clear however the practice of mission always has been very diverse, ranging from religious conversion through preaching and evangelisation "to serving the poor and the marginalised without being vocal in faith" (Clarke 2012a, p. 2). Furthermore, missionary organisations should be considered important forces in development co-operation due to their strong links to local communities. Community-focused models of development have become increasingly important during the last decade. Missionary organisations could be attractive stakeholders: development service of missionary organisations is hold to be very efficient, because they are locally rooted and have national, international and ecumenical networks. Furthermore, mission organisations profit greatly from voluntary work. Volunteering is often understood as a part of the calling of practising Christians. Moreover, the work of missionary organisations often concentrates on areas which are difficult to access for the state. Finally, but no less importantly, mission organisations as religious organisations have better possibilities to work together with religious leaders. Religious leaders are often the most trusted people in developing countries (James 2011, p. 111). Through analysing the project work of Basel Mission/Mission 21 these statements will be accentuated later.

Criticism related to religious character is an issue dealt with not only by mission organisations, but by any FBO. The critiques are not limited to the issue of proselytization. FBOs are also accused of acting alone and in isolation, not willing to collaborate with other FBOs or secular organisations, and of contributing to tensions and conflicts (Heist and Cnaan 2016, pp. 11-13). Furthermore, it is not only mission organisations nor FBOs that have been a disputed topic in the development discourse: religion and spirituality on the whole have been longtime neglected subjects. In the year 2000, spirituality was still considered taboo in development theory and practice. The sociologist Kurt Allen Ver Beek sees four possible reasons for this: a "fear of imposing foreign perspectives, a dichotomising Northern perspective, a fear of conflict, or the lack of precedent or models" (Beek 2000, p. 40). While Ver Beek emphasises the important role of spirituality in development issues, other authors stress the distinction between FBOs and NGOs and the importance and contribution of faith-based organisations to development work (Ware et al. 2016). During the last 15 years, spirituality, religion and FBOs have played an increasingly important role in development discourse contemporary development studies also deal with the impact of religion and spirituality (Déneulin and Bano 2009). Many topics have been researched in this field, for instance, the impact of distinct religious beliefs on development (for the impact of Pentecostalism see Freeman 2012; for the impact of different religious beliefs Mtata 2013 or Faschingeder and Six 2007), and how FBOs seek to influence the debates at UN level (Haynes 2014). Historical and contemporary case studies 
on the connection between mission and development also have emerged (Clarke 2012b; Lounela 2007; Biehl 2013). Secular development discourse is slowly opening towards the longstanding and contemporary involvement of Christians in development initiatives.

The discourse on development has changed: Today it is a discourse against a concept of materialistic development, only concerned with economic growth. Today, the discourse on development fosters a holistic understanding of development, including human beings in all their aspects. This approach becomes visible in the SDGs meaning that mission organisations can strongly contribute to such a discourse. For a long time, mission organisations have been dealing with the understanding of mission. The connection between evangelisation and diaconia meaning caring for your neighbour or social welfare - in the missionary work was very much disputed and scrutinised. The concept of "Missio Dei" that emerged in the 1950s widened the scope and understanding of mission. Mission is not an activity of the church, but a movement from God to the whole world and is understood as a "holistic mission", targeting the whole creation in all its aspects (Bosch 1991, pp. 389-393).

\section{From Basel Mission to Mission 21: historical background and self-concept}

Mission 21 was founded in 2001 but it has a long history. We will have a closer look at two important dates: 1815 and 1963.

In 1815, Basel Mission - the strongest supporter of today's Mission 21 - was founded. Since the founding days, Basel Mission has always been a heterogeneous, interdenominationally organised institution with a very hierarchical structure. Basel Mission was founded at the beginning of the "great missionary century" (Warneck 1880), when many other mission organisations were born. There are several reasons for this emergence. On the one hand, at the beginning of the 19th century the political circumstances in many colonies changed, and mission organisations were increasingly tolerated. On the other hand, the reasons for this departure can be found in a new awakening movement, through which new networks occurred, linked together transnationally and interdenominationally (Mack 2013, pp. 44-45). Basel Mission is an interdenominational mission organisation as belonging to a specific church is not a condition for the admission of a missionary, so the organisation is therefore unable to build upon a specific church community to back them up (Schlatter 1916, p. 277). Basel Mission is, like many other mission organisations, a "parachurch" (Pierard 1999, p. 11) and is strongly based on the principle of volunteering. Theologically, Basel Mission is rooted in the tradition of pietism, a religious renewal movement within the Protestant churches, starting in the 17 th century and having its prime times in the 18 th century. Pietism, broadly spoken, pushes for individualising and internalising of the religious life. New forms of personal piety and communal life emerged. Furthermore, caring for the poor, diaconia, became increasingly important (Wallmann 2005, p. 21). Within the work of Basel Mission, individual conversions were very 
important; the "targets" of a missionary were individuals, not clans, tribes or peoples. It was important to educate the individuals in Christian faith before they could be baptised. Eschatological and biblical motives were central in their work due to these pietistic foundations. From their beginnings Basel Mission always linked evangelisation and diaconia. Poverty reduction, better schooling and social welfare were as important as preaching and spreading the gospel within the work of Basel Mission.

In 1963, KEM (Cooperation of Evangelical Missions in Switzerland) ${ }^{4}$ was founded. This cooperation was in some way similar to Mission 21 today. It amalgamated several Protestant mission societies in Switzerland, but there was one important difference: one main ambition of KEM was to work more closely together with the reformed churches in Switzerland, not only for financial motives but also for theological reasons. Mission was seen as a part of the church. The aims of this new co-operation entailed the co-ordination of the work in Switzerland, joint finances and building a future where mission is part of every church and every Christian. This close link between the reformed churches and the mission societies released a mood of new beginnings all over Switzerland. Mission was now understood as something which is also important at home, not only overseas (Huppenbauer 2014, p. 11). In 1983, this new understanding of mission led to guidelines for developmental thinking and action. These guidelines had the aim of showing possibilities and limitations of political joint responsibility in mission. Many new relief and development projects emerged at that time. They led to the critique that KEM was too heavily involved with the churches in Switzerland and with developmental questions and was forgetting the real task of mission (Huppenbauer 2014, p. 64). In 1999 Basel Mission resigned from KEM, predominantly due to financial reasons, but theological reasons, also led to this breakup: In the eyes of Basel Mission, KEM was heading too much towards being a relief organisation and their work was not focussing enough on a holistic understanding of mission (Huppenbauer 2014, pp. 130-134). KEM was dissolved in December 2000. Mission 21 was founded in January 2001 and, unlike Basel Mission, the Protestant churches of Switzerland were not part of its founding organisations.

Today, Mission 21 is a worldwide community of churches, missions and development organisations. The work of Mission 21 extends to different countries. The partner organisations associated in continental assemblies are members of Mission 21; the Basel Mission, the Evangelical Mission in the Kwango and the Moravian Church are supporting associations of Mission 21. The 200-year-old Basel Mission is the strongest supporter and supplies the background of Mission 21. The board or the management of Mission 21 in Basel is not the highest decision-making body of Mission 21: the Mission Synod has this position, where all the sponsoring organisations are represented by a total number of 45 delegates. It decides upon the programmatic and theological orientation of Mission 21, upon intermediate and long-term aims and upon the financial planning. The Mission Synod meets once every three years. Mission 21 sees itself as an international learning community (Mission 21 2016b), thus all aims and projects have to be developed together with the partner organisations. Differences in understanding 
of the aims and goals of Mission 21 or of the whole project work can lead to severe conflicts between the management board in Basel and the partner organisations. The aims and principles of Mission 21 are very much rooted in the Gospel of Jesus Christ and in their history. A short film, which was produced for the 200year anniversary of Basel Mission, tries to link the history of Basel Mission with the work of Mission 21 today (Mission 21 2016c). This film depicts where Mission 21 comes from and is very much interested in presenting the similarities and the differences between the early missionary days and the situation today: Mission 21 did not just turn from being a missionary to a development organisation. The core themes and goals in the past and the present day are very much alike. Mission 21 wants to present itself to the public as a non-profit and charitable organisation with a religious background and motivation. The central words in this short film are "hope" and "justice", words which are crucial not only in a religious context. The film does not use language limited to a Christian audience. One finds no bible verses, no links to Jesus or mission; even broader theological terms like charity or diaconia are omitted. "Hope", "justice", "love" and "respect" are frequently used catchwords which can be used both in secular and religious contexts.

\section{The WCC and ecumenical approaches to development}

Basel Mission and Mission 21 belong to the ecumenical movement of Christianity. The World Council of Churches (WCC) is the broadest and most inclusive organisation within the organised expressions of this ecumenical movement. The 348 member churches reflect, speak, act, worship and work together on several topics, always with the goal of visible unity (World Council of Churches 2016a). Regarding the notion of development within the ecumenical movement several conferences and considerations within the WCC have been crucial. I will give a brief overview in the following section.

Peace, justice and sustainability are very important terms within development organisations today. The WCC has considered the connection between justice, peace and sustainability for about 40 years. The term and concept of a sustainable society was introduced in Bucharest in 1974 (World Council of Churches 1974, p. 2). The WCC General Assembly adopted this concept in Nairobi in 1975. Because social justice was at least as important as sustainability, they chose to speak of a "sustainable and just society" as the goal of the ecumenical movement (Albrecht 1991, p. 963). In his speech in Nairobi, Charles Birch, an Australian biologist and theologian, emphasised that the "struggle over the body of earth . . . involves a programme of de-development of the rich world" (Birch 1976, p. 69), meaning that fundamental change of heart and mind about humankind's relationship to nature is needed to obtain a just and sustainable society. In the following decades, the discourse on sustainable development obtained new elements, and thus ecological questions appeared. At the Vancouver Assembly in 1983 the trilogy of Justice, Peace, Integrity of Creation (JPIC) was promoted. In 1988 the WCC launched its Climate Change Programme. After the Assembly in Harare in 1998, environmental questions became strongly connected with the subject of 
indigenous people around the world. In 2006 the commission for Justice, Peace and the Integrity of Creation presented an alternative globalisation programme in Porto Alegre addressing people and earth. The programme is called "a call to love and action: Agape". The commission emphasised that a world without poverty the goal of the MDGs - is not only possible but is in keeping with the grace of God for the world (Commission for Justice, Peace and Creation 2005).

The discussion within the WCC was, from the beginning, questioning an understanding of development which was solely orientated on economic growth. The discussions within the WCC on development were influencing the changes in the overall concept of development over the last 50 years (Zaugg-Ott 2004, p. 22). The climax of the debates on development within the WCC lies in the time between 1968 and the end of the 1970s and in the early 1980s. The most important decisions were taken throughout this period, which have been shaping the developmental attitude within the WCC ever since. Since the end of the 1960s the WCC has been committed to a developmental model which is not focused on economic growth, but on a responsible society with justice for everybody. Development within the ecumenical world means that development is "human development, which allows the individual as well as the society to bring the possibilities of human life in social justice, self-reliance and economic growth to its full realisation" (Gruber 1970, p. 122; translation CH). Aside from this definition, development was increasingly becoming a taboo word, because it was associated with economic growth only, for example the WCC Commission on Churches' Participation in Development clearly states: "As early as 1957 the then existing South East Asia Conference of Churches declared: 'Development is not our word'" (CCPD 1990, p. 5). Within a solely materialistic notion of development, social concerns and environmental issues would not be sufficiently considered. The ecumenical meaning of development had to be recaptured where development means a people-centred and justice-oriented process. Such a process can fit within a Christian context, guided by the words of Jesus in Matthew 6:33: "Set your mind on God's Kingdom and his justice before everything else" (CCPD 1990, p. 6). Until the end of the 1970s the term "liberation" - coming from the liberation theology from Latin America - was the alternative to the term development; Justice, Peace and Integrity of Creation became leading concepts in the development policy of the WCC (Zaugg-Ott 2004, pp. 393-405).

We can conclude with Kurt Zaugg-Ott that the early claims for an orientation of the development programmes for the very poorest of the world resonated with the secular world. The term "human development", which was present in the WCC in the 1970s, became the title of a UNDP report in 1990: "Human Development Report". But it can be critically argued that the problems of the world focused in the WCC were only in a prophetic manner. The constructive dispute and the collaboration of churches regarding concrete solutions took a backseat behind accusations and confessions of resistance.

Aside from this theological understanding of development work, a holistic understanding of mission is important for the ecumenical movement. The term 
"Missio Dei" has become crucial for the ecumenical movement since the second half of the 20th century. Missio Dei means that the Trinitarian God is the subject of mission. Mission is therefore not church-centred but theologically centred. Such an understanding of mission can be interpreted socio-critical and church-critical. Mission in this sense of the word is not limited to a historical phenomenon of the 19th and 20th centuries, but understood as a transformative dynamic: God is constantly working towards the salvation of the whole world, "This mission spirituality has a dynamic of transformation which, through the spiritual commitment of people, is capable of transforming the world in God's grace" (World Council of Churches 2012, pp. 4-5).

To sum up, the ecumenical discussions on development and mission deliver an alternative approach to development, both in practice and in theory. The focus lies on human development and eco-justice, not only on economic wellbeing. Values of inclusion, compassion and justice play important roles in religions and can broaden the approach to development. Development is understood as an expression of the church's mission, but not in the sense of modernising using Western role models (Faschingeder 2007, p. 18). Development within an ecumenical understanding is a call for transformation not involved in an ideological construct linked to geopolitical interests. Such an understanding of development comes from the capacity to create visions of a "life in abundance" and from engaging patiently and in the long term with others.

\section{Principles of development work within Mission 21}

The ecumenical understanding of mission and development and the three key terms of ecumenical considerations and discussions, Justice, Peace and the Integrity of Creation, have been crucial in the project work of Mission 21 over the last few decades. The work and self-identity of Mission 21 is clearly rooted in the ecumenical movement. The two projects that I explore in this contribution are related in different ways to the ecumenical understanding of mission and development: the Farming Centre Project is very much engaged with the "integrity of creation" and "justice", while the newer programme "Empowerment of Basic Groups" has "peace" and "justice" as two main foci. Although Mission 21 is confronted with similar problems as other organisations and institutions of development work, the work of Mission 21 has its roots very much in its theologicalecumenical foundations, rather than in secular concerns about development. The principles on which Mission 21 is built make it a faith-based organisation. ${ }^{5}$ Its self-identification in its mission statement speaks clearly - Mission 21 is permeated by Christian faith:

Our hopes and plans for the future are guided by the Gospel of Jesus Christ. The Gospel gives us the vision of the Kingdom of God, where there is justice, freedom, reconciliation and healing. This vision motivates us to take responsibility for the world in which we live. 
The Christian faith is an important but not an exclusive foundation for the work of Mission 21. Believing in Jesus Christ is not a condition for working within Mission 21. Nevertheless, acknowledging that spiritual dimensions are very important for the organisation's transformation and development work is self-evident for Mission 21's employees. If the organisational form of Mission 21 is taken into account, its degree of formality and relationship with other structures, it is quickly apparent that Mission 21 is more than an exclusively Christian mission. It is a formally independent NGO, and it has strong ties to the Reformed Church in Switzerland, but also to other faith-based and secular structures. Almost 15\% of their financial resources are state funded (Mission 21 2014b, p. 32). Mission 21 received a government seal (ZEWO) for its development work in December 2014. The highly regarded seal guarantees an efficient and effective use of the resources, transparent information, open communication and fair fundraising (Zewo Foundation 2016). Donors have benefitted from tax deductibility since 2012 (Mission 21 2016a).

Mission 21 is active in different development fields in which secular development organisations are also engaged. Recently, Mission 21 has been very active in the fields of advocacy and gender equality, but the reduction of poverty, rural development, health care and peace work are still important activities. Policy making, networking and classical development work are core tasks of Mission 21. Programmes and Projects on Interreligious Dialogue and Theological Education illustrate that Mission 21 is a faith-based organisation. The specific characteristic of the development work of Mission 21, distinguishing it from the development work of secular NGOs, is their religion-based context and the setting of long-term partnerships. Most of the partner organisations of Mission 21 emerged through its missionary work and today are independent churches. These relationships have developed into a partnership of equals since the independence of the churches in the mission fields in the second half of the 20th century (Mission 21 2013b, pp. 7-8). The one-sided subject - object approach, which shaped early mission and development work, has changed into a dynamic and multipolar network of relationships.

The work of Mission 21 has two foci, which are closely linked together: theological work and development work. This is very much visible in the Tumbang Lahang Farming Centre project: in a boarding school that forms part of this project, young men not only learn new agricultural techniques to achieve better harvest, but the whole education system is built upon Christian doctrines. Mission 21 is based on a holistic understanding of mission: the proclamation of the gospel and diaconia, social and welfare work, all belong closely together. The Gospel has spiritual and social aspects and implications which Mission 21 considers in their development work. Development work within Mission 21 means "church related social work and lived multipolar relationships within the worldwide ecumenical movement" (Mission 21 2013b, p. 10; translation $\mathrm{CH}$ ). The aim of such development work is to "protect human rights of the marginalised and vulnerable communities of the poorest countries, irrespective of their religion, gender, ethnicity, social status or sexual orientation", to foster resources and capacities of 
such communities. Partner churches and organisations implement these aims and Mission 21 supports this work through financial aid and professional know-how (Mission 21 2013b, p. 10; translation CH). For Mission 21 the classical development projects to reduce poverty and end hunger are framed by theological and educational programmes. Theological and cultural exchange is Mission 21's centrepiece, its identity, and constitutes a great difference to non-religious development NGOs.

How does this focus go along with projects in development co-operation? Jochen Kirsch (Director of Mission 21 since September 2019, before Head of International Relations and member of the Executive Board) describes theological education as the motor of social transformation, therefore the motor of development. The starting point of Mission 21's work is to consider the burning issues of their project partners, for example land grabbing, ethnic minorities or interreligious conflicts. These issues are then included in their theological education programmes. The outcomes and insights, which are found through the process of theological education, are then brought back to the burning issues where development work is the output. The idea of such a theological education is to increase the Churches' awareness of the significant problems in their countries. Only through such awareness will they become motivated to implement development projects. ${ }^{6}$

Funding structures in Switzerland forced Mission 21 to differentiate between religious and development projects. State money is only granted for secular projects, as no religious programmes can be supported with the funding that comes from the Swiss Agency for Development and Cooperation (SDC). Despite the fact that Mission 21 only receives a comparatively small amount of state money, it was forced to separate two areas that - in its understanding - belong closely together. Why is the relatively small amount of state-funded money so important for Mission 21? It is not the money which is important per se, but the relationship to the state. Being supported by the SDC improves Mission 21's recognition in the Swiss public view: an organisation with links to the state is considered to be more trustworthy by donors.

\section{Project work of Mission 21}

After outlining Mission 21 as an organisation and its principles, this chapter now turns to the examination of two development projects of Mission 21 in Kalimantan, Indonesia. Before the analysis of these two projects is presented, investigating whether the notion of development has changed over the years, the following section will provide details of the context of the projects.

\section{Project context}

Kalimantan, formerly known as South Borneo, was the last missionary territory of the Basel Mission. Basel has been sending missionaries to South Borneo since 1920. The war years and the Japanese occupation 1941-1945 was a watershed for Kalimantan. Neither the attempt to re-establish the Dutch colonial rule nor 
the approach of a federal system was successful. A complete break with the past was needed. The younger generation in Kalimantan took the initiative to end foreign domination and to incorporate Kalimantan in the independent and Unitarian Republik Indonesia in 1950 (Gin 2013, p. 148).

Kalimantan is the biggest island of Indonesia, a country with a Muslim majority. About $88 \%$ of the population belong to the Islamic faith. Christian organisations such as Mission 21 can only survive due to the particular Indonesian politics of religion. Indonesia is not an Islamic state and it is not built on Islamic Rights. Indonesia is a democratic and secular state, yet religion plays a very important role in politics. The concept of Pancasila - meaning five pillars - on which the whole modern state of Indonesia is built upon, has as its first principle the faith in one god: Ketuhanan Yang Maha Esa. Belonging to a religion is compulsory for every Indonesian citizen, and the state tries to protect all accepted religions (agama), which covers Islam, Protestantism, Catholicism, Hinduism, Buddhism and Confucianism.

In 2014, the new president Joko Widodo - called Jokowi - was elected. This election was seen as a turning point in the era of reformasi (since the downfall of Suharto in 1998): Jokowi is the first president who neither belongs to the elite of the Suharto dictatorship, nor is he a member of one of the political dynasties. He is not connected to corruption and stands for religious tolerance. This is significant as during the last couple of years Indonesia has been confronted with problems due to a growing fundamentalist Muslim population. Fundamental Islamic teachers from abroad have been influencing the local population and the traditional and tolerant Islam. This has led to several difficulties; for example, conflicts around church constructions have emerged, and in some regions in Java and Sumatra churches had to be closed down. The evangelical wing of the Christians reacted with strong missionary work and crusades in areas which are mostly populated by Muslims (Woischnik and Müller 2014). In order to have better control over fundamentalist teachers and preachers, the state began to check all foreign workers. As such, receiving a working visa is becoming increasingly difficult. Kalimantan is not so much confronted with problems around a growing fundamentalist population, but with conflicts between different ethnic groups. After 1998 the tensions between the local Dayak groups and the immigrants from Madura increased and caused violent conflicts between the years 1999 and 2004. As well as these socio-political conflicts, deforestation is also causing ecological and economic problems. Mission 21 takes these circumstances very much into account when working in the area. The emphasis on educational programmes in Kalimantan today has its roots in the deforestation of the island. The local population is still capable of living from the crops of their land, but often the money for school fees, books and uniforms is missing.

\section{A classical development project: Farming Centre Tumbang Lahang}

The Farming Centre in Tumbang Lahang - which was launched in 1955 and closed down in 2011 - was a project of the Kalimantan Church in connection with 
Basel Mission. The project started not long after the inaugural speech of President Truman in 1949, which is considered the beginning of development policy (Rist 2014, pp. 70-71). The initiative for the Farming Centre came from one of the first local pastors, Isom Birim. During a synod in Kasongan, Birim named the nomadic life and the type of agriculture of the local farmers - that is, shifting cultivation as the cause for all their distress. The overall accepted assumption was that modern farming techniques would bring higher agricultural yields and better living conditions. Birim asked Basel Mission for help. The village Tumbang Lahang, situated in the upper basin of the river Katingan, donated 58 hectares of land for the Farming Centre. Basel Mission could not afford money for the project but allowed one of their missionaries, Gustav Flach, to support this Farming Centre. During his holiday at home in Switzerland, Flach was able to collect 20,000 Swiss Francs to buy tools and materials which were most needed for the project (Stuby 1967, pp. 28-34). In January 1955, more than one ton of agriculture equipment such as ploughs, harrows, chains and scythes was shipped on the river Katingan towards Tumbang Lahang (Flach 1956a, p. 3). The Farming Centre Project was in at least two ways "avant la lettre". It was based on a co-operation between the local autonomous church, the political community and foreign assistance. Furthermore, this local and church-related initiative started five years before the Federal Council of Switzerland established a service for technical assistance, a very early form of federal development co-operation (Swiss Agency for Development and Cooperation SDC 2016).

The aim of the project was to keep the young men in their villages in regions far away from the cities and to help them enhance their agricultural income. The Evangelical Church of Kalimantan did not want a "leap from the old to the very latest, the most modern, but a healthy way of improvement" (Flach 1956a, p. 4; translation $\mathrm{CH}$ ). Some new technologies, like the plough and the harrow, were brought to the upper river basin of the river Katingan. A classical development project in the field of poverty reduction was implemented. The project was designed to lead the local farmers "from agricultural exploitation (by burning of forests) to profitable modern farming techniques" (Basler Mission 1969, p. 1; translation $\mathrm{CH})$. The Farming Centre Tumbang Lahang was an official church agency, not a private or a governmental project. It was not affiliated with any larger association for development work, but worked together with one specific donor agency: Basel Mission. The Training Centre received not only capital funds from the donors, but also equipment, expert guidance and training of personnel in the country. The project was also part of the Indonesian government programme to multiply the food potential. Next to the Farming Centre there was also a health centre for several decades (Riwut 1964). These projects were strongly motivated by biblical concepts. Project initiators spoke of Jesus being the bread of life. Another project, the school in Tumbang Lahang, was conceptualised as a sign of "loving your neighbour as yourself" - the most important commandment in Christianity.

However, the school will offer more than pure development; it wants to be a sign of charity and a place of fraternal encounter and thus bear witness to Christ. 
The agriculture students will be guided to a new understanding not only of fellow humans but of all of nature, which no longer has to be feared as a sinister power and unpredictable fate, but can be experienced as the creation of God.

(Dumartheray 1967, p. 64; translation CH)

Material development aid was strongly connected to a certain kind of spiritual development. The whole understanding of development was based on Christian theology. In the 1960s, conversion to a new understanding of nature was one important aim of the project. The new understanding was clearly defined: it was a Christian understanding. The presence of a missionary, or later called fraternal or ecumenical co-worker, could lead to the impression that evangelisation or proselytization was an aim of the work of Basel Mission in Tumbang Lahang. The Europeans were only responsible for the development work, not for counselling or theological tasks. This duty was fully under the authority of the local pastors and evangelists. Proselytizing was therefore not an explicit goal of the work of the Basel Mission in Kalimantan (Flach 1961). Furthermore, proselytizing was not only a problem within Christian circles, but also secular development projects had "transformative goals" (Fountain 2015, pp. 89-90).

Gustav Flach (1908-2001) was the first project manager. Flach, a male nurse, was sent out to Kalimantan in 1938 as a classical missionary with the task of spreading the gospel and helping the local people to become "civilised". In these colonial times this meant having access to school, hygiene and health concepts, which were imported by Europeans. After six years at the river Kahayan and an internment during the Japanese occupation 1944-1945, Flach returned to Switzerland as a mission preacher for two years. In 1947, he was sent out to Kalimantan again, where he first replaced his colleague Hans Schärer after his sudden death in Banjarmasin, and then came to the Katingan River, where he spent five years in Kasongan. In 1954, he was then sent to Tumbang Lahang to lead the Farming Centre (Flach 1956a, p. 2). ${ }^{7}$ Flach and his wife left Kalimantan in 1965. Gustav Flach embodies the figure of a classical missionary. He stayed for a very long time - almost 30 years - in one mission field. During all these years, he gained a high level of knowledge of the local language and culture, which helped him to implement his development work in a more effective way. Due to the motivation of his work through his faith, he also made sacrifices such as being separated from his children for 10 years. How he managed the different tasks in the 1930s and the 1950s is difficult to say. Did he leave the evangelisation to the local pastors, and did he only focus on farming techniques in the 1950s and 1960s? Or was evangelisation even understood as agricultural training?

In July 1955, the first farming course for young men started. Six young men from the upper river basin participated. In the meantime, a course on how to run a household for girls was also initiated, in which 22 girls participated. In Tumbang Lahang, corn was planted in the spring months, then sweet potatoes, peanuts, soybeans and small green peas. In September, rice could also be planted. The first harvests were very rich (Flach 1956b). The reaction of the local population to the Farming Centre and these changes was ambivalent. On the one hand, they were 
already used to the presence of European missionaries. The village of Tumbang Lahang appreciated the presence and work of missionary Hans Schärer during the 1930s very much (Flach 1956b). Schärer was collecting myths and traditions of the local population and was thus able to compile an important heritage. On the other hand, the distrust of the local population was quite strong in the beginning of the Farming Centre. They saw the new farming methods as the cause of their problems. Despite these reservations, in 1958 there were a lot of young men from all regions of Kalimantan who wanted to join the Farming Centre, and a school village with 20 houses was built; however, the people of the village remained sceptical. In the late 1960s, the persons responsible for the Training Centre mentioned that the involvement and co-operation of the people of the village still lay below their expectations. The cause was seen in the traditional way of life and thinking, which was very difficult to change (FAO 1969, p. 10).

The pupils of the Farming Centre's boarding school had to be older than 15 years. They did not have to be Christians; they only had to want to work and know how to read and write before they could join the two-year course. The students received theoretical education in plant cultivation, commercial plants, husbandry, manure use, vegetable gardening, dendrology, tool and machine use, economy and agriculture. Right from the beginning the emphasis was placed on practical education. The teachers were a mix of Indonesian locals and foreigners. The Farming Centre proved very important for the rural and agricultural development of the region (Stuby 1967, pp. 52-59).

After a successful foundation phase, by the 1970s this project started to gain criticism within Basel Mission. Christoph Zimmermann (1932-2003), who was a teacher at the Theological Seminary in Banjarmasin from 1964 to 1970, was very critical towards centres like Tumbang Lahang, where new technologies were set up. In his eyes, these were means which remained unreachable for the local farmers. Moreover, he criticised that the conditions which were very different in every village were not seriously taken into account. According to Zimmermann, the local farmers already knew what was good for their land. After an agricultural education in Switzerland, Christoph Zimmermann and his family were invited by the East Kalimantan church GKPI to work with them. In the years from 1974 to 1980 Zimmermann, together with the church management and an agricultural team, developed another method. All his thinking was nourished by the concept of the gospel of "caring for the small people". He established a holistic service which linked the gospel to the daily problems of a farmer (Lutz 2004). Together with the local church in East Kalimantan, Zimmermann developed a training course for farmers in three steps. The first step was a pre-course for farmers in Tarakan, where the farmers had to show whether they really loved farming and were not afraid of getting dirty hands. The second step was a course in Bali, where they should learn the caring system from the Hindu people. After these two months, they came back and had a lot to discuss, which was the third step. This is where the Sekolah Penyambung Lidah, the tongue extension school, was born. In this way a network of farmers, teachers and church leaders was built who travel from village to village and talk about improving their farming systems (Zimmermann 2004). 
In the 1970s two types of training or educating farmers were practised within Basel Mission in co-operation with their partner churches. Although these two kinds of projects led to conflicts within the management board in Basel, it demonstrates that Basel Mission was not a homogenous organisation where only one opinion or strategy prevailed. Several strategies were practised to achieve the important goal of improving the living conditions of the people at the margins. Local creativities and experiments were taken into account to reach this goal.

In the 1980s the Farming Centre in Tumbang Lahang was confronted with different problems. A church journal was speaking of "development victims" (kurban pembangunan) in the outback of Kalimantan. Due to an improved road system, many young people did not stay in the villages anymore, but were trying their luck in the bigger cities. Farming was becoming increasingly unattractive. Deforestation also frequently caused severe problems for farming in the outback such as flooding (Horoni 1985). As a result, the number of students in the Farming Centre declined. The students realised that the technical and mechanised training they received in Tumbang Lahang was not practical when they were back in their villages. To educate students and send them back to their traditional surroundings did not bring the expected change to the traditional farming system (Siebert 1978). The main goal of the project, to overcome shifting cultivation through the introduction of settled crop rotation agriculture, was not achieved. In 1986, a new concept of the Farming Centre was arranged by Basel Mission and the Kalimantan Church. The Farming Centre should have three sectors: a consultation programme for farmers, nine family farms in Tumbang Lahang with internship places and a service and co-ordination office. The formal training should be put in the hands of the government, whereas the Farming Centre should offer only informal training. This new concept was never really implemented (Basel Mission 1990). In 1989 the Dutch government started to finance an Agricultural High School in Tumbang Lahang, but in 1992 the Indonesian government prohibited all financial help from the Dutch government. It was then when Basel Mission took responsibility for the Agricultural High School, and it survived for another 10 years. In 2003, formal education that combined theory and practice was still seen as the right way for education in the outback of Kalimantan. In 2001 the school was accredited by the state. The farming skills and working ethos, which were achieved by the practical work that supplemented theory in the Farming Centre of Tumbang Lahang, were highly commended. This dual system, with roots in Switzerland and Germany, gave the students the possibility to achieve a degree in their original location, while the practical work ensured a significant added value to other curricula which are only based on theoretical knowledge. However, the practical work was not sufficiently planned and organised in Tumbang Lahang (for further reading: Heinrich 2003). Besides this, both the educational and the income-generating parts of the project were not sufficiently separated. A strategy and financial plan were missing, the education of the local personnel was not professional enough and the relation to the state development programme remained unclear (Heinrich 2003). These circumstances caused increasingly severe problems. Furthermore, personnel constellations and differing interests - above all different ideas for leading the 
project between the responsible persons in Basel and Kalimantan - led towards huge conflicts. These conflicts were responsible for the phasing out of Basel Mission's support in 2011. With this phasing-out, the whole project of the Farming Centre in Kalimantan failed: the once very important Farming Centre in Tumbang Lahang was no longer of any importance to the GKE church. The long-term goal of the church is now to maintain land and property in Tumbang Lahang. The failing of this project brings to light to two distinct problems of development work. Firstly, co-operating closely with local partners can be very difficult because of differing expectations and backgrounds. Secondly, when the financial subsidy of a project withdraws, the whole project is in danger of failure.

To close this section, we discuss the notion of development that is highlighted in this project. A rather technical notion of development is evident within this project. The Farming Centre was understood as part of the construction and development of this country, still in its infancy. The project was very much in line with secular projects with the aim to eradicate hunger. The education in the Farming Centre should have led to another farming system - settled crop rotation agriculture instead of shifting cultivation - which in turn should have led to higher harvests; however, this goal was not achieved. The interesting part of this project is not its success or a specific notion of development, but the engagement of a development organisation from Europe with local partners. As many other mission organisations, Basel Mission/Mission 21 has a long history of active engagement with material wellbeing and a long-term partnership with local actors (James 2011). The Centre in Tumbang Lahang was a vivid sign of Basel Mission's engagement for the local Dayak people. A pastoral concern - that the shifting cultivation makes a strong community life impossible - led to the launching of an educational centre concerned with development. The pastoral engagement for the Dayak people is a golden thread in the work of Basel Mission in Kalimantan. Despite the paradigmatic shift in Mission History in the 1950s and 1960s, after which foreign missionaries were not as tolerated in many countries, the Farming Centre in Tumbang Lahang was a legendary project of co-operation between the local church GKE and Basel Mission. Decisions were made together - the Centre was led by a local; foreign co-workers only came by invitation of the GKE. For almost a hundred years Basel Mission/Mission 21 has worked together with the same partner. Their work is based on a strong relationship, which has already endured several difficulties. The ecumenical co-worker marks a difference to other development co-operation agencies. The ecumenical co-worker stands under the authority of the local partner institution and guarantees the exchange between the local organisation and the programme managers in Basel. He or she is an intermediary between two cultures, strives for the flow of information and can mediate in conflict situations. During the high times of the Farming Centre of Tumbang Lahang, the co-worker still had a very important role and kept his influence even after the 1950s. He was the linchpin in the mission field between the local Christians and the "motherhouse" in Basel. Nowadays, the relationships have totally changed. Neither the missionary nor the "motherhouse" in Basel play this central role anymore. Given that Mission 21 seeks an equal partnership with 
their partners abroad, the position of the ecumenical co-worker has drastically changed. Nevertheless, he or she still is very important for successful project work.

\section{A new programme: empowerment of basic groups}

Since 2011 many amendments to the programme and Mission 21's project work have been made, which caused major changes to the support of Mission 21 in Kalimantan. The range of financial support for projects overseas has been shrinking over the last few years due to fewer donations to Mission 21 and to the orientation of the organisation towards state-funded subsidies. As discussed above, state money is not allowed for religious projects.

Moreover, institutional core themes have been defined only over the last few years. All programmes of Mission 21 have to belong to one of the four core themes: Education, Advancement of Peace, Agriculture and Income, or Health. The goals of Mission 21 are very clear: through the measures in the four core themes, Mission 21 aims to contribute to a life in dignity and enable the local population to manage life self-determinedly and independently in order to support social processes and changes. Co-ordinated programmes have been established for every continent over the period of 2015-2018. Regarding the Asian context, Mission 21 now has a regional focus on Indonesia (Java and Kalimantan), Malaysia (Sabah) and Hong Kong. This geographical scope is wider than the whole of Europe. The thematic focus lies on three of the four main foci of Mission 21: Education, Advancement of Peace and Agriculture and Income. Projects in the area of Health are being phased out (Mission 21 2015a).

"Empowerment of Basic Groups" is the newest programme from Mission 21 in Indonesia. It is established within the core theme of Education (Mission 21 2016e). This programme is concerned with the holistic living and thinking of Mission 21 's partner organisations, which are mostly churches or church-related institutions. In this programme, theological education and classical development work refer to and question one another. In the beginning, Contextual Theology was the subtitle of this programme. Due to structural financing reasons described above, the subtitle was discarded. However, within the activities of this programme, contextual theology still plays a crucial role. The programme is based on the assumption that the fostering of contextual theology is important, because within such a theological thinking, the concrete needs and challenges in a region are taken into account. Theology transforms through the influence of proper information, and vice versa - theology can help to transform the perception of reality. Such a theological approach can furthermore assure that not only imported Western theology is taught in the Indonesian theological institutes. Mission 21 has made positive experiences from a theological distance-learning programme (TEE) in the Church of the Brethren (YEN) in Nigeria. Through this learning programme the environmental awareness of the church leaders could be changed (Kirsch 2014).

Identity-forming organisations, such as churches or Islamic organisations, are held in high regard in Indonesia. Religious communities and their leaders often 
enjoy more trust than governmental bodies. Church leaders are key persons, and therefore crucial for social transformations. ${ }^{8}$ Because of this, they could play an important role for initiatives of development co-operation. However, the churches in Indonesia do not see initiatives such as fighting poverty or social differences as their core tasks; they delegate these tasks to the state. This is where Mission 21 sees a deficit in the education of pastors. A contextual theology is missing (Mission $212013 a$ ).

The goal of the new programme is for the church and community to take on contextual theology as both perspective and method in their work within multicultural society of Indonesia. The term "contextual theology" is used in a very broad sense; it means developing a theology that reacts to the burning issues of the current context, in this case the Indonesian and Malaysian partner institutions of Mission 21. These core issues where found by a baseline study conducted by Indonesians and managed by the programme manager in Basel in 2013. Although academics where involved in the study, the discussion about what contextual theology is or means was missing. The strength of the study lies in the involvement of different people, academics, practitioners and men and women of different ages and educational backgrounds. Through the perspective and method of contextual theology, church leaders are motivated and sensitised to social engagement and development co-operation. With this approach, Mission 21 also sees a possibility to make the relevance of a church development co-operation visible. The church is, in their eyes - and also in the eyes of their Indonesian partner organisations an important stakeholder for social development (Yewangoe 2013).

Since 2015, a regional co-ordinator in Indonesia is guiding and monitoring this programme. Mission 21 works together with different institutions: Firstly, they have four theological institutes as their programme partners (Christian University Duta Wacana in Yogyakarta, two theological colleges of the Kalimantan church, theological seminary in Sabah); secondly, the communion of churches in Indonesia (PGI, Persekutuan Gereja-Gereja di Indonesia) and thirdly, three other national associations (such as the theological publishing house in Jakarta Gunung Mulia, women theologians PERUATI and theological institutes PERSETIA). Theologians, pastors, lecturers, activists, intellectuals and artists are communicating the core themes of the programme: Justice, Peace Building and Recognition of Diversities. Theological curricula and models of church services are also based on these core themes. The first and most important target group of this programme are the leaders of the theological institutes. With a theology linked to the social context, the pastors (the second target group) are motivated to participate in social engagement and can sensitise their communities to the burning issues Indonesia is confronted with today. The first output of this programme should be research concerning the questions of land grabbing, the relations between majorities and minorities and ethnic and religious discrimination. Publications and conferences, networks of contextual theologians in Indonesia should be established (Mission $212015 b)$.

Local experts are given priority within this programme. If there are not enough local experts, senior experts from Germany and Switzerland provide occasional 
support. Long-term deployment of foreign personnel decreased because of the financial situation of Mission 21. In the field of theology, however, foreign experts are still essential, not only because of the lack of knowledge in Indonesia, but also because these experts are seen as ideal bridge builders. They are playing an important role for Mission 21's identity as they guarantee the expected exchange. ${ }^{9}$ The existence of such co-workers constitutes a difference to other development co-operation agencies. The ecumenical co-worker is part of the local church structure. Ecumenical co-workers are under the authority of the local partner organisations. For Mission 21 the exchange is their centrepiece; the ecumenical co-workers therefore play crucial roles.

It is still too early to see results of this programme, only the pursued result can be named: social change can be achieved in Indonesia through religious key persons. If the theological education is more sensitive to social problems, the future leadership can be motivated to deal with social engagement and development work. For example, due to his research in rural areas of Kalimantan, pastor Marko Mahin ${ }^{10}$ learned that education is the only way to escape poverty. He set up a scholarship programme which yearly gives 200 young people from rural areas of Kalimantan the possibility to study at the Christian University in Palangkaraya. After their studies, they go back to their communities to bring the knowledge to the poorest members of the society (Mission $212015 \mathrm{~b}$, p. 24). To date, 600 students have been sponsored.

\section{Churches as stakeholders of social development}

To conclude this analysis, I will now highlight how the concept of development that became apparent through the description of these varied projects is related to the ecumenical understanding of development. First of all, it is important to record that the notion of development is regularly scrutinised and evaluated within Mission 21. It has always ranged from material to social or spiritual development. The Farming Centre of Tumbang Lahang had a dual approach: on the one hand, the farming project to produce higher income; on the other hand, the boarding school to seek transformation of old and traditional behaviour. Newer projects place a stronger emphasis on social transformation. This is clear in the programme "Empowerment of Basic Groups": churches are seen as stakeholders in social development. The task to further material development is left to other organisations or expected automatically from the social transformation. "Social development" became a keyword for the work of Mission 21. The notion of development shifted from a more technical approach to one that is more focused on empowerment and theology; this is strongly related to the discussions in the WCC. There, even since the 1960s, development is not focused on economic growth but on a responsible society with justice for everybody. Development within Mission 21 is also related to a holistic understanding of mission. Mission here means a transformative dynamic, where the world can be transformed in God's grace. Therefore one could say that development is understood here as a "holistic transformation", where spiritual and material dimensions are connected. 
Within Mission 21, development in the sense of improvement or transformation has been understood as a part of mission since the beginnings of the work of Basel Mission in Kalimantan in the 1920s and 1930s. In those days, two kinds of "missionaries" were sent out. On the one hand, Basel Mission had "ordinary missionaries" in the field to spread the gospel and lead the population to conversion. These missionaries committed their lives to Basel Mission and were often in one missionary territory for decades. On the other hand, "development co-workers" with special education have been sent out with a limited working contract to help to improve the living conditions in a mission field. Mission doctor, Dr. med. Mattheus Vischer-Mylius, with specialist knowledge in surgery and tropical medicine, built up a health centre in the outback of Kalimantan in the 1930s Early on, Basel Mission had a focus on improving the health situation in other parts of the world. The doctor treated everyone - in his hospital there was also a prayer area for Muslims. The mission doctor had a difficult position among the ordinary missionaries; he was not accepted as one of them. ${ }^{11}$ In these early days a clear distinction between the missionary and his work and other co-workers and their work was made. Nowadays this distinction is no longer relevant as development work is clearly a part of mission, not something that can be separated.

Regarding this early development work of a mission doctor one question emerges: can humanitarian aid and charitable work provided by a mission doctor be classed as development work? The distinction between charity and development is quite unclear. One could speak of social or human development when the work is for the long term and striving for a sustainable change. Charity would then mean short-term and donor-driven work, which provides help for disaster or humanitarian relief (Deacon and Tomalin 2015, p. 70). Within such an understanding of development, we can say that Mission 21 has engaged in development work right from the beginning in the 19th century. The work of Basel Mission was always for the long term and striving for sustainable change. Basel Mission realised very early on that religious convictions can either cause development or hinder such transformations. Long before the term and concept of development was created after the Second World War, Basel Mission was already dealing with the questions and problems that the concept of development involves.

\section{Conclusion}

The two central interests of this chapter were to investigate how the notion, implications and activities of development within Basel Mission/Mission 21 changed over time or to what extent a certain continuity becomes visible. Furthermore, this contribution wanted to shed light on the underestimated role of a mission organisation within the development discourse.

Mission 21 has been adapting their self-concept and their notion of development to the changing world. A certain shift was found from a more technical understanding of development work in the Farming Centre of Tumbang Lahang in the 1950 s to the current understanding of development which is roughly based on social transformation. We can therefore conclude that despite its fixed foundation 
on Christian faith, a mission organisation can be flexible in their thinking and perception of the world. Besides adaption, continuity is also an important feature within Mission 21's understanding of development. The justification of development work has always been the same. For Mission 21, theology and theological education is the centrepiece of their development work - all the rest follows. Without a Christian motivation, this work would not be done. Without theological thinking, the kind of development targeted by Mission 21 would not be achieved. The theological background of Mission 21 is strongly formed by a holistic understanding of mission. Mission is not only a means of attracting people to the Christian faith by evangelisation, it also stands for fighting for justice. Mission is not only words but also deeds. Diaconia and evangelisation are inextricably linked. Not only evangelisation but also diaconia have always been crucial within the Basel Mission. The letter of appointment to Christoph Gottlieb Blumhardt, the designated leader of the mission institute in planning, says that the aim of the mission institute should be to educate missionaries, "as disseminators of a charitable civilisation and preacher of the gospel of peace to different parts of the pagan world" (Basel Mission 1815-3.9.1818, p. 20; translation CH). This "charitable civilisation", which dates back to the year 1815, was also seen as reparation of injustice, which was caused primarily by Europe in Africa for many centuries (Rennstich 2015, pp. 104-105).

The goals of mission target human wellbeing, the flourishing of life, which includes the physical and the spiritual wellbeing of human beings (World Council of Churches 2012). Mission always has a vertical and a horizontal dimension. The vertical dimension concerns the relationship between God and His creation, the horizontal dimension the relationship amongst the whole creation:

A Christianity which has lost its vertical dimension has lost its salt and is not only insipid in itself, but useless to the world. But a Christianity which would use the vertical preoccupation as a means to escape from its responsibility for and in common life of man is a denial of the incarnation.

(Bosch 1991, p. 408, quoting the Uppsala Report of the World Council of Churches 1968)

Good technical knowledge can lead to development, but this is not sufficient. Development also needs a vertical dimension. This is a very clear statement, which has been adopted by Mission 21. By suggesting alternative perspectives on development, FBOs such as Mission 21 act as so-called development entrepreneurs. Nevertheless, the question of how this vertical dimension can be linked to the responsibility for common life, and how this vertical dimension is linked to development work, has not yet been answered. It remains surprising that even a mission organisation like Mission 21 is still trying to work out how religion is related to development.

With the description of the work of Basel Mission and Mission 21 in Kalimantan, a reshaping of the idea of what type of actor started development could be achieved. Development work was not just invented after the Second World War 
by the inaugural speech of President Truman. Long before, in several faith-based organisations, especially mission organisations, development work had been done. It is only recently that mission organisations have also been made visible for academic discussions on development. For a long time, religion and spirituality have been a taboo in discussions on development work. Mission organisations had a very difficult standing because of the assumption that they only wanted to convert people to Christianity and were not at all sensitive to local cultures and behaviours. We have seen that this assumption ought to be reconsidered. Conversion is a problem which is not confined to faith-based organisations, but also to secular organisations which sometimes also work converting people to their secularised worldview or civilisation theories (Heist and Cnaan 2016, p. 12).

The description and analysis of the two projects show that mission organisations have their limitations but can also add value to development work. The limitations concern their structures and their willingness to function in different discursive fields (Koehrsen and Heuser 2019 in this volume) - in the secular field of development and state funding, but also in religious contexts. This often means a balancing act and can lead to severe tensions within an organisation. Tensions can also occur between the management board in Basel and the partner institutions where the ideas how to lead a project can widely differ. In these cases, Mission 21 acts as a "boundary agent" (Koehrsen and Heuser 2019 in this volume) by balancing the diverging expectations from different fields.

The four ways in which missionary organisations can contribute to development work in a specific manner that were described at the beginning of this chapter will now be outlined for the case of Mission 21: Firstly, the project work of Basel Mission and Mission 21 in Kalimantan is efficient, because it was and is locally rooted within the local autonomous church and also within the political community. Furthermore, the projects can build upon ecumenical national and international networks, such as the communion of churches in Indonesia but also the WCC. Through the local church GKE, Mission 21 is connected with all other Protestant churches in Indonesia. In Switzerland, Mission 21 can also use church structures for funding. As such, Mission 21 creates a nexus between different types of actors from various fields. Secondly, about 30,000 hours of voluntary work per year is done within Mission 21 (Dietschy 2011, p. 3; Herrera 2011). Volunteering is strongly understood as part of the calling of many donors and coworkers within the network of Mission 21. Thirdly, the work of mission organisations reaches the poorest at the margins. Kalimantan is a region in Indonesia which is far from the centre and often not considered by the state. The development work of Mission 21 in co-operation with their partners is therefore crucial. Finally, Mission 21 is a religious organisation and has therefore the opportunity to work together with religious leaders in Kalimantan. Mission 21 cooperates with churches and theological training centres, but also with other religious organisations. In Kalimantan, Mission 21 works together with LK3, ${ }^{12}$ a Muslim organisation. LK3 was not only able to establish a strong interreligious network (Mission 21 2016d), but they also do a lot of research on Islam and society. These studies have an impact on the intellectual discourse in the society, and the studies can also 
be applied to solving social problems. Therefore, this collaboration has an impact on the local development work in Kalimantan.

\section{Notes}

1 In the 1980s, the term "fraternal co-worker" was changed to "ecumenical co-workers" by demand of the Women's Commission of the Basel Mission.

2 Oral information from Magdalena Zimmermann, Head of Department Education Exchange Research, deputy director of Mission 21, Basel 27 April 2016.

3 The term "faith-based organisation" is controversially discussed. I use a very broad definition of this term. Faith based then means value based. For a further discussion see, for example, Nordstokke (2013).

4 Kooperation Evangelischer Missionen. Evangelical is used in a broad sense and roughly means Protestant missions. In German we can differentiate between "evangelisch" and "evangelikal". Dena Freeman's contribution in this book deals with evangelical missions, a certain wing of Protestant missions, which are more conservative and often more right wing.

5 To research FBOs it is reasonable to use a defined typology in order to better know, what is meant by the term "faith-based", see Occhipinti (2015); Clarke (2006). Occhipinti suggests characterising FBOs according to three dimensions. First the ways in which they are "faith-based", second their activities and third the degree of formality and relationships with other faith and non-faith structures.

6 Interview with Jochen Kirsch, Head of the Department for International Relations, Mission 21, Basel, 16 April 2015. See also a presentation by Jochen Kirsch at the Annual Meeting of DEZA (Direktion für Entwicklung und Zusammenarbeit), in which he gave an example from Nigeria where a theological correspondence course had a strong influence on the participants concerning their environmental awareness and behaviour (15 May 2014).

7 In 1939 Flach married Elisabeth Wittwer (1907-1976) in Kalimantan and they had four children. The youngest died in a Japanese detention camp one day after his birth. The three remaining children of the Flach family stayed in Switzerland after a vacation in 1954. All information about Gustav Flach is taken from the personal records of Gustav Flach stored in the Basel Mission Archive (BV 2395).

8 Interview with Christian Wagner, Programme Officer Indonesia-Malaysia Mission 21, Basel, 19 May 2015.

9 One ecumenical co-worker is involved in this programme: Uwe Hummel, a lecturer at the Theological Seminary of the Evangelical Church of Kalimantan in Banjarmasin. $\mathrm{He}$ is not the leader or co-ordinator of the programme - it is led by the Indonesian theologian Kinurung Maleh Maden - but he participates in the activities.

10 Pastor Marko Mahin is not only the co-principal of the Christian University in Palangkaraya, Central Kalimantan, but also holds a doctoral degree in anthropology. He researched the traditional Dayak religion Kaharingan.

11 Interview with Marianne Dubach-Vischer, daughter of the mission doctor Mattheus Vischer-Mylius (05.09.2016).

12 Lembaga Kajian Keislaman dan Kemasyarakatan (Institut für das Studium von Islam und Gesellschaft).

\section{References}

Albrecht, P., 1991. Sustainability. In: N. Lossky, ed. Dictionary of the Ecumenical Movement. Geneva: WCC Publications, 963-964.

Basler Mission, 1815-1818. Protokoll der 5. Komiteesitzung, 13. November 1815. Basel. 
Basler Mission, 1969. Projektbeschreibung Tumbang Lahang (B-18-2,1).

Basler Mission, 1990. Referat für Sabah und Ostkalimantan, Stabstelle Landwirtschaft. GKE Landbauzentrum Tumbang Lahang, Kalimantan (Indonesien). BfB Nr. 820907. Projektverlauf 1983-93 (B-40.1,11).

Beek, K.A. ver, 2000. Spirituality: A Development Taboo. Development in Practice, 10 (1), 31-43.

Biehl, M., 2013. Religion, Development and Mission. In: K. Mtata, ed. Religion: Help or Hindrance to Development? Leipzig: Evangelische Verlagsanstalt, 97-119.

Birch, C., 1976. Creation, Technology and Human Survival. The Ecumenical Review, 28 (1), 66-79.

Bosch, D.J., 1991. Transforming Mission: Paradigm Shifts in Theology of Mission. New York, NY: Orbis Books.

CCPD, 1990. The Commission on Churches'Participation in Development ... Works with Churches in Solidarity with the Poor. Geneva: World Council of Churches.

Clarke, G., 2006. Faith Matters: Faith-Based Organisations, Civil Society and International Development. Journal of International Development, 18 (6), 835-848.

Clarke, M., 2012a. Introduction. In: M. Clarke, ed. Mission and Development: God's Work or Good Works? London: Continuum, 1-15.

Clarke, M., ed., 2012b. Mission and Development: God's Work or Good Works? London: Continuum.

Commission for Justice, Peace and Creation, 2005. Alternative Globalization Addressing People and Earth-AGAPE. A Call to Love and Action [online]. Available from: www. oikoumene.org/en/folder/documents-pdf/pb-06-agape.pdf [Accessed 22 October 2016].

Deacon, G., and Tomalin, E., 2015. A History of Faith-Based Aid and Development. In: E. Tomalin, ed. The Routledge Handbook of Religions and Global Development. London: Routledge, 68-79.

Déneulin, S., and Bano, M., eds., 2009. Religion in Development: Rewriting the Secular Script. London: Zed Books.

Dietschy, B., 2011. Freiwillige vervielfachen unsere Arbeit. Contigo. Mitteilungen der evangelischen Werke für die Kirchgemeinden, 1, 3.

Dumartheray, R., 1967. Nachwort. In: M. Stuby, ed. Tumbang Lahang. Basel: Basileia Verlag, 61-64.

FAO, 1969. Food and Agriculture Organisation, Freedom from Hunger Campaign. Questionnaire Assessment of Field Activities in the Spirit of the FAO F.F.H.C. (B-18-2,1). Basel.

Faschingeder, G., 2007. Entwicklungsproduktive Religiositäten und Entwicklung als religiöse Idee - Zu den zahlreichen Möglichkeiten, das Verhältnis von Religion und Entwicklung zu denken. In: G. Faschingeder and C. Six, eds. Religion und Entwicklung: Wechselwirkungen in Staat und Gesellschaft. Wien: Mandelbaum-Verlag, 16-59.

Faschingeder, G., and Six, C., eds., 2007. Religion und Entwicklung: Wechselwirkungen in Staat und Gesellschaft. 1st ed. Wien: Mandelbaum-Verlag.

Flach, G., 1956a. Aus der Arbeitsgemeinschaft für junge Landwirte in Tumbang Lahang (B-11.15). Basel.

Flach, G., 1956b. Aus der Arbeitsgemeinschaft für junge Landwirte in Tumbang Lahang (Kalimantan). Der Auftrag. Organ der Evang. Missionsgesellschaft in Basel (früher “Der Heidenbote”), 1 (8), 178-184.

Flach, G., 1961. Es geht mit der Landbauschule Tumbang Lahang voran. Der Auftrag. Organ der Evang. Missionsgesellschaft in Basel, 6 (5/6), 57-59.

Fountain, P., 2015. Proselytizing Development. In: E. Tomalin, ed. The Routledge Handbook of Religions and Global Development. London: Routledge, 80-97. 


\section{4}

Claudia Hoffmann

Freeman, D., ed., 2012. Pentecostalism and Development. Churches, NGOs and Social Change in Africa. Basingstoke: Palgrave Macmillan.

Gin, O.K., 2013. Post-War Borneo, 1945-1950: Nationalism, Empire and State-Building. London: Routledge.

Gruber, P., ed., 1970. Ungerechte Fesseln öffnen: Offizieller Bericht der Konferenz über ökumenische Unterstützung für Entwicklungsprojekte. Montreux, Schweiz, 26.-31. Januar 1970. Genf: Ökumenischer Rat der Kirchen.

Haynes, J., 2014. Faith-Based Organizations at the United Nations. New York, NY: Palgrave Macmillan.

Heinrich, H., 2003. Bericht zur Evaluation des Landwirtschaftsprojekts und des landwirtschaftlichen Gymnasiums der Evangelischen Kirche in Kalimantan GKE vom 28.9.-12.10.2003 (225.1014 GKE. Landbau \& Entwicklung. Evaluation + Umsetzung. 2003-2009).

Heist, D., and Cnaan, R.A., 2016. Faith-Based International Development Work: A Review. Religion, 7 (19), 1-17.

Herrera, M., 2011. Freiwilligenarbeit für mission 21. Diplomarbeit Basel [unpublished document of Mission 21]. Basel.

Heuser, A., 2016. Die 'verkannte Schwellenzeit' der Missionsgeschichte. Erkundungen zur postkolonialen Formierungsphase des Diskurses um Weltchristentum. In: M. Delgado, M. Sievernich, and K. Vellguth, eds. Transformationen der Missionswissenschaft. Festschrift zum 100. Jahrgang der ZMR. St. Ottilien: EOS Verlag, 268-278.

Horoni, A., 1985. Laporan Perjalanan. Ada,Kurban Pembangunan' di Pedalaman Kalteng. Oikumene, 109, 24-28.

Huppenbauer, H.W., 2014. Aufbrechen und verharren. Kirche und Mission am Beispiel der KEM. Kooperation Evangelischer Kirchen und Missionen. Affoltern am Albis: H.W. Huppenbauer.

James, R., 2011. Handle with Care: Engaging with Faith-Based Organisations in Development. Development in Practice, 21 (1), 109-117.

Jenkins, P., 1998. Kurze Geschichte der Basler Mission. 2nd ed. Basel: Basler Mission.

Kirsch, J., 2014. Der Beitrag von mission 21 zum Thema "Religion \& Entwicklung”: Fallstudie Nigeria. DEZA-Jahrestagung. [unpublished document of Mission 21]. Bern.

Koehrsen, J., and Heuser, A., 2019. Beyond Established Boundaries: FBOs as Developmental Entrepreneurs. In: J. Koehrsen and A. Heuser, eds. Faith Based Organisations in Development Discourses and Practice. London: Routledge.

Lounela, J., 2007. Mission and Development: Finnish Pentecostal, Lutheran and Orthodox Mission Agencies in Development Work in Kenya 1948-1989. Åbo: Åbo Akademis Förlag.

Lutz, H., 2004. Gute Botschaft für Bauern. In: Mission 21, ed. Zum Andenken an Christoph Zimmermann. Basel [unpublished document of Mission 21], 13-16.

Mack, J.U., 2013. Menschenbilder: Anthropologische Konzepte und stereotype Vorstellungen vom Menschen in der Publizistik der Basler Mission 1816-1914. Zürich: Theologischer Verlag Zürich.

Mission 21, 2013a. Programm ,Stärkung von Basisgruppen-Kontextuelle Theologie, Mai 2015; Executive Summary. Zusammenfassung des Abschlussberichtes über die BaselineStudie für das M21-Schwerpunktprogramm "Kontextuelle Theologie”. Basel [unpublished document of Mission 21].

Mission 21, 2013b. Vorstandsbeschluss vom 11.10.2013. Basel [unpublished document of Mission 21]. 
Mission 21, 2014a. M21 Leitbild 2014 mehrsprachig [online]. Available from: www.mis sion-21.org/de/ueber-uns/portraet-der-organisation/ [Accessed 23 October 2016].

Mission 21, 2014b. Tätigkeitsbericht 2013. Basel: Mission 21.

Mission 21, 2015a. Antrag_CP_IndoMalay\&HK_2015-18.pdf. Basel [unpublished document of Mission 21].

Mission 21, 2015b. Grunddokumentation Schwerpunktprogramm 200.1010. Kontextuelle Theologie-Stärkung von Basisgemeinschaften. Basel [unpublished document of Mission 21].

Mission 21, 2016a. Häufig gestellte Fragen [online]. Available from: www.mission-21.org/ de/spenden/wissenswertes-fuer-spendende/haeufig-gestellte-fragen/steuerlich-absetz bare-spenden/ [Accessed 24 October 2016].

Mission 21, 2016b. Mission Synod [online]. Available from: www.mission-21.org/en/mis sion-21/mission-synod/ [Accessed 22 October 2016].

Mission 21, 2016c. Our Mission [online]. Available from: www.mission-21.org/en/mis sion-21/our-mission/ [Accessed 22 October 2016].

Mission 21, 2016d. Partnerorganisationen in Indonesien [online]. Available from: www. mission-21.org/projekte-und-partner/partner/indonesien/ [Accessed 27 October 2016].

Mission 21, 2016e. Stärkung von Basisgemeinschaften [online]. Available from: www. mission-21.org/projekte-und-partner/projekte/asien/indonesien/project/462/?tx_hfprojektdb_pi1[backpid] $=1007$ [Accessed 24 October 2016].

Mtata, K., ed., 2013. Religion: Help or Hindrance to Development? Leipzig: Evangelische Verlagsanstalt.

Nordstokke, K., 2013. Faith-Based Organisations and their Distinct Assets. In: K. Mtata, ed. Religion: Help or Hindrance to Development? Leipzig: Evangelische Verlagsanstalt, 225-242.

Occhipinti, L., 2015. Faith-Based Organizations and Development. In: E. Tomalin, ed. The Routledge Handbook of Religions and Global Development. London: Routledge, 331-345.

Ott, C., Strauss, S.J., and Tennent, T.C., 2010. Encountering Theology of Mission. Grand Rapids, MI: Baker Academic.

Pierard, R., 1999. Significant Currents in German Protestant Missiology. Currents in World Christianity Position Paper Number 102. Cambridge: University of Cambridge, Currents in World Christianity Project.

Rennstich, K.W., 2015. Die Anfänge der Basler Mission. In: A. Kittel, ed. Unterwegs zu den anderen: 200 Jahre Basler Mission und Württemberg. Das Buch zur Ausstellung. Riederich: Logo Print, 102-105.

Rist, G., 2014. The History of Development: From Western Origins to Global Faith. 4th ed. London: Zed Books Ltd.

Riwut, T., 1964. Gubernur Kepala Daerah Kalimantan Tengah, Ketua DPRD. Kundjungan singkat, 7.9.1964, Tumbang Lahang (B-18-2,1).

Schlatter, W., 1916. Die Heimatgeschichte der Basler Mission. 1815-1915. Basel: Verlag der Basler Missionsbuchhandlung.

Siebert, R., 1978. Asmans lange Reise in eine neue Zeit. Landwirtschaftliche Entwicklungsprojekte der Basler Mission im indonesischen Urwald (I). $n z$ am Wochenende. 13.09.1978 (B-40.1,13).

Stuby, M., ed., 1967. Tumbang Lahang. Basel: Basileia Verlag.

Swiss Agency for Development and Cooperation SDC, 2016. History of the SDC [online]. Available from: www.eda.admin.ch/deza/en/home/sdc/portrait/history.html [Accessed 27 December 2016]. 


\section{6}

Claudia Hoffmann

United Nations, 2016. We Can End Poverty [online]. Available from: www.un.org/millen niumgoals/ [Accessed 27 October 2016].

Wallmann, J., 2005. Der Pietismus. Göttingen: Vandenhoeck \& Ruprecht.

Ware, V.-A., Ware, A., and Clarke, M., 2016. Domains of Faith Impact: How "Faith" Is Perceived to Shape Faith-Based International Development Organisations. Development in Practice, 26 (3), 321-333.

Warneck, G., 1880. Warum ist das 19. Jahrhundert ein Missionsjahrhundert? Halle: Julius Fricke.

Woischnik, J., and Müller, P., 2014. Indonesien [online]. Available from: www.kas.de/wf/ doc/kas_38335-1522-1-30.pdf?140711103745 [Accessed 22 October 2016].

World Council of Churches, 1974. Study Encounter 69, Vol X, 4. Geneva: World Council of Churches.

World Council of Churches, 2012. Together Towards Life [online]. Available from: www.oikoumene.org/en/resources/documents/commissions/mission-and-evangelism/ together-towards-life-mission-and-evangelism-in-changing-landscapes [Accessed 23 October 2016].

World Council of Churches, 2016a. About Us [online]. Available from: www.oikoumene. org/en/about-us [Accessed 22 October 2016].

World Council of Churches, 2016b. History [online]. Available from: www.oikoumene. org/en/what-we-do/cwme/history [Accessed 22 October 2016].

Yewangoe, A., 2013. Churches as Stakeholders for Social Development. Jakarta [unpublished document of Mission 21].

Zaugg-Ott, K., 2004. Entwicklung oder Befreiung?: Die Entwicklungsdiskussion im Ökumenischen Rat der Kirchen von 1968 bis 1991. Frankfurt am Main: Otto Lembeck.

Zewo Foundation, 2016. Enhancing Donors Trust - Charity Monitoring and Donor Information [online]. Available from: www.zewo.ch/ [Accessed 22 October 2016].

Zimmermann, C., 2004. Wie man zu den Bauern kommt. In: Mission 21, ed. Zum Andenken an Christoph Zimmermann. Basel [unpublished document of Mission 21], 21-25. 


\title{
3 Mobilising evangelicals for development advocacy \\ Politics and theology in the Micah \\ Challenge campaign for the Millennium Development Goals
}

\author{
Dena Freeman
}

\section{Introduction}

Evangelical Christians are known for their inner worldly religion and their focus on personal morality and spiritual experience. Yet since the second half of the 20th century a gradual process of opening up to consider also this-worldly matters has begun to take place in certain quarters of the Evangelical world. One of the drivers behind this 'new evangelical social engagement' (Steensland and Goff 2014) has been the involvement of Evangelical relief and development NGOs in humanitarian work in the global South. The number of Evangelical development NGOs has increased exponentially during this time and the amount of money donated by Evangelicals and their churches has also soared (Reynolds and Offut 2014, p. 248). Evangelicals have developed their own theology of development, known as 'integral mission' or 'transformational development,' and which now guides the development work of most Evangelical NGOs (Freeman 2018). This theology has sought to open up traditional notions of sin and redemption and to shift them from being seen as personal matters and to argue that they are deeply social. And a focus on the coming of the just and harmonious Kingdom of God has shifted the locus of redemption from the individual to 'all of creation' and from the far future to the 'already/not yet'.

The latest stage in this process of Evangelical opening to worldly matters has been the recent move towards Evangelicals getting engaged in advocacy on development issues. At present this is quite a tentative step, still met with much reticence and resistance. For most Evangelicals to start to engage with politics on behalf of the global poor is still a step too far. Nonetheless, in 2004 the first Evangelical transnational advocacy campaign for justice for the poor was set up. This campaign, called the Micah Challenge, sought to mobilise the global Evangelical church to advocate to their national governments to do what they could to end global poverty, and in particular to support the Millennium Development Goals. This chapter looks at the genesis of the Micah Challenge and explores the way in which it sought to develop a theology of justice and advocacy in order to try to mobilise Evangelicals to campaign on behalf of the poor. It shows how the tension between the personal and the social, the inner-worldly and the outer-worldly, 
shaped the way that Micah Challenge communicated about development advocacy and ultimately led to a paradox which it could not overcome. To make justice and advocacy palatable to global Evangelicals it had to develop a theology which placed a great emphasis on personal morality and spirituality, and yet in doing so it lost focus on the global political and economic issues that it wished to raise.

This study also seeks to make a theoretical contribution to the literature on religion and development. While much of this literature has focused on the role of religion in development cooperation, particularly looking at how faith-based organisations (FBOs) may, or may not, be effective at implementing development projects (e.g. Clarke 2008; Ter Haar and Ellis 2006; Tomalin 2015), there have been calls to widen out the research focus to consider also other aspects of the religion and development nexus (e.g. Jones and Petersen 2011). This chapter seeks to consider the role of FBOs in mobilising the public, or a specific religious constituency, to campaign for development outcomes. It thus speaks to other recent work that has sought to look at forms of religious action in the UN (Haynes in this volume; Haynes 2014) and forms of religious action in the global economy more generally (Dreher and Smith 2016). And by exploring the way that the Micah Challenge sought to change the development discourse of a particular religious constituency, the study presents an interesting case of development entrepreneurship (Koehrsen and Heuser 2019 this volume).

The chapter starts by giving a brief overview of the history of Evangelical social action and then goes on to explore the new Evangelical theology of development which came to the fore in the latter half of the 20th century and upon which all subsequent developments build. It then looks at Evangelical involvement in the Jubilee 2000 anti-debt campaign and shows how this laid the groundwork for the Micah Challenge to emerge a few years later. After exploring the genesis and rationale for the Micah Challenge, the chapter goes on to consider in detail the theology of justice and advocacy which it developed in order to mobilise Evangelicals for development advocacy. It concludes by arguing that even though the Micah Challenge sought to connect the personal and the structural in their theology, they ultimately did not manage to overcome the theological blocks which this constituency has regarding engaging in development advocacy. ${ }^{1}$

\section{A brief history of Evangelical social engagement}

It is important to start by looking at the history of Evangelical social engagement as this will show the changing context in the Evangelical world out of which the Micah Challenge emerged. Evangelicalism started in the 1730s as a Christian revival movement in the UK and Europe and quickly spread to America, where it grew rapidly to become one of the country's largest religious movements. It was later spread round the world by Evangelical missionaries, and there are now Evangelical churches in most countries. Evangelicalism offers an intensely personal Christianity by fostering a deep sense of spiritual conviction and personal redemption, and by encouraging introspection and a commitment to a new standard of personal morality (Bebbington 1993; Ditchfield 1998; Hutchinson and Wolffe 2012). 
During the 18th and 19th centuries Evangelicals engaged with society as part and parcel of the practice of faith. Prominent British Evangelicals, such as John Wesley and William Wilberforce, worked tirelessly for social reform and the end of slavery, and 19th-century Evangelical politician Lord Shaftesbury passed acts in parliament to alleviate some of the injustices caused by the Industrial Revolution, such as prohibiting the employment of women and children in coal mines and establishing a ten-hour day for factory workers (Heasman 1962; Finlayson 1981).William Carey preached and planted churches in India, whilst also speaking out against the caste system (Tizon 2011, p. 62). In Australia Evangelicals were amongst those leading the call for the rights and humane treatment of the indigenous population (Sloane 2011, p. 3). American Evangelicals established charities and philanthropic organisations to help the poor and were amongst the most active social reformers during this time, campaigning to improve the conditions of prisoners, running orphanages and founding homes for juvenile delinquents (Steensland and Goff 2014, p. 5; Young 2006). Charles Finney, a leading American Evangelical revivalist, could write in the mid-19th century:

The great business of the church is to reform the world. The Church of Christ was originally organised to be a body of reformers. The very profession of Christianity implies the profession and virtually an oath to do all that can be done for the universal reformation of the world.

(cited in Tinker 1999, p. 2)

However, in the early decades of the 20th century two processes led to Evangelicals retreating from their engagement with the world and developing an increasingly privatised, inner-worldly religion. The first was a reaction to the so-called 'social gospel', a theology that was growing in popularity in the liberal wings of the Protestant church, and that argued that the role of Christians was not to save souls so that they would get a place in heaven, but rather to reconstruct society on a Christian basis so that life on earth would become as harmonious as that in heaven. The second was a shift within Evangelical circles to a dispensationalist premillennial theology which considered that there was no way that people could improve their worldly lot, and that things would only get worse and worse until Jesus returned and brought about heaven on earth. Within such a theology social reform was seen as futile and hopeless, while saving souls became a matter of utmost urgency. The combined effect of these two factors, within the broader context of the post-Enlightenment privatisation of religion, led to Evangelicals retreating almost entirely from any kind of social engagement in the first half of 20th century (Moberg 1972). This approach to spirituality and the material world was then spread around the globe by Evangelical missionaries, with the result that most of the newly forming indigenous Evangelical churches in the global South largely also adopted this focus on the inner spiritual life, with little interest in social engagement (Tizon 2011, p. 62). The social gospel movement became firmly entrenched in the mainstream Protestant ecumenical movement as embodied by the World Council of Churches, and Evangelicals distanced themselves 
from this movement and instead built their own global ecumenical movement in the form of the World Evangelical Alliance.

Whilst the first half of the 20th century was characterised by an almost total lack of social engagement by Evangelicals, the second half of the century was increasingly taken up by discussions questioning this position. This was started in 1947 by the publication of The Uneasy Conscience of Fundamentalism by Carl Henry, a leading American Evangelical theologian, which reflected on earlier Evangelical social action and called for a return to this kind of activity. Since then increasing numbers of Evangelicals have started to engage in social issues. Many are focussing on the poor in their own communities and in nearby neighbourhoods. This is now increasingly common, for example, in the Vineyard Movement (Bialecki 2008, 2009) and in the Emerging Church movement (Bielo 2011, 2014) and even amongst conservative Evangelicals (Elisha 2008, 2011). There have also been calls from progressive evangelicals to engage with poverty more widely and to consider the poor across the globe (Gasaway 2014; Pally 2011; Sider 1977; Swartz 2012a, 2012b). In the global South, Evangelicals are also increasingly getting involved in politics (Freston 2001; Ranger 2008). These communities all represent very different wings of Evangelicalism, and they approach these issues in quite different ways. Nonetheless, this 'new evangelical social engagement' represents a major sea change in many quarters of global Evangelicalism and has only recently begun to receive serious scholarly analysis (Steensland and Goff 2014). In this chapter I will focus on just one movement within this broader sea change, and that is the group of Evangelicals engaging in relief and development work overseas and promoting an approach called integral mission or transformational development.

This particular movement was largely started by Evangelicals living in the South, particularly in Latin America. Living close to poverty and inequality, and influenced by the social action of Catholic Liberation Theology, theologians from the Latin American Evangelical Fellowship, notably Rene Padilla and Samuel Escobar, sought to develop a new theology which would integrate both evangelism and socio-political involvement on behalf of the poor into a holistic unity. They wanted to respond to the same realities addressed by liberationists while still upholding their evangelical commitments to the authority of scripture, the divinity of Christ and the necessity of evangelism. Their solution, which they called 'misíon integral', or integral mission, emphasized an incarnational and kingdom-centred theology which claimed that because Jesus was Lord over all of creation and all spheres of life, there was no real distinction between serving spiritual needs and serving physical needs. From this perspective the mission of the church could not simply be reduced to winning converts but must also include action on behalf of the poor and for social justice (Carpenter 2014, p. 274; Clawson 2012, p. 792). In the 1960s they began to increasingly participate in international Evangelical conferences, and they started to push for their vision of a more holistic understanding of the gospel that included social engagement. This was not an easy discussion and many conservative Evangelicals pushed back and argued that their one and only focus should be evangelism. In the meantime 
Evangelical missionaries working oversees and carrying out humanitarian work became troubled at the lack of theology to justify their actions (Padilla 2002, p. 2; Tizon 2011, p. 66).

These tensions came to a head at the Lausanne Conference in 1974, attended by some 2,500 Evangelicals from 150 countries. Rene Padilla and Samuel Escobar both gave provocative plenary addresses presenting their theology of 'misíon integral', and calling on Evangelicals to get involved in social action. These addresses generated a lot of discussion and in the resulting Lausanne Covenant there was an entire section on Christian social responsibility, which stated that 'we affirm that evangelism and socio-political involvement are both part of our Christian duty . . . the salvation we claim should be transforming us in the totality of our personal and social responsibilities' (cited in Clawson 2012, p. 796).

Whilst Lausanne was a key turning point regarding Evangelical engagement with social issues, it was not the end of the story. In the following years fierce battles raged in the Evangelical world about whether Evangelicals should engage in social action or remain focused solely on evangelism, and whether mission should include humanitarian action or should focus only on converting the unreached peoples. The fundamentalists were not easily swayed, particularly those from North America, and they continued to argue for the focus on saving souls.

During this same time, and in parallel, several Evangelical relief and development NGOs were formed. In America the National Association of Evangelicals established World Relief in 1944, World Vision was founded in 1950, Compassion in 1952, Samaritan's Purse in 1970 and Food for the Hungry in 1971 (Reynolds and Offut 2014, p. 244). In the UK the Evangelical Alliance established Tearfund in 1968, and in the following years similar Tear or Tearfund organisations were set up in Australia (1971), New Zealand (1973), the Netherlands (1973), Belgium (1979) and Switzerland (1984). Some smaller Evangelical development organisations were also set up in other European countries. These NGOs got involved in humanitarian relief work, and later in development work, even though there was no specific Evangelical theology of social engagement or of international development. For the most part they carried out development projects in much the same way as secular development NGOs worked at the time (Freeman 2018).

\section{Development as transformation: the theology of integral mission}

Starting in 1980, however, Evangelicals began to work on developing a new theology of international development to guide their actions. The first important steps were taken during the World Evangelical Fellowship consultation which culminated in the Wheaton Statement of 1983, and which set out the outlines of a specifically Christian approach to development. Crucially, the participants chose to move away from the term 'development', with its connotations of modernity, materiality and sole focus on economic growth, and instead adopted the term 'transformation'.2 
The Wheaton statement describes transformation in the following way:

Transformation is the change from a condition of human existence contrary to God's purpose to one in which people are able to enjoy fullness of life in harmony with God. This transformation can only take place through the obedience of individuals and communities to the Gospel of Jesus Christ, whose power changes the lives of men and women by releasing them from the guilt, power, and consequences of sin, enabling them to respond with love toward God and toward others. ... The goal of transformation is best described by the biblical vision of the Kingdom of God.

(World Evangelical Fellowship 1983)

The statement goes on to talk about different aspects of transformation, and claims that to move towards living under God's reign requires not just the spiritual transformation of individuals, but also the transformation of economies, cultures and socio-political systems. It presents a vision of holistic change leading in the direction of the Kingdom of God.

The worldview underlying integral mission theology is based on the doctrines of creation, fall and redemption. In this view God created the world and created people to live together in harmony, to be stewards of the earth and to share its resources equitably. However the fall was brought about by the work of the devil and people's innate tendency to self-interest. It led to human existence becoming corrupted and bent away from God's intentions. From an integral mission viewpoint this includes social sin and corruption as well as individual sin and corruption. Economic systems, political systems, cultures, society, all became infused with evil and twisted from what God had intended. This, then, is viewed as the fundamental cause of poverty and injustice. God's intention, however, is redemption. In the theology of integral mission redemption is not solely a personal, private affair, but it also social and worldly. Redemption is for all of creation. A central facet of redemption, in this understanding, is bringing about the Kingdom of God, in which there will be harmony, peace and justice.

Followers of integral mission draw on the Kingdom theology developed in the 1950s by George Eldon Ladd, Professor of Biblical Theology at Fuller Theological Seminary. In his view, the Kingdom is not a special realm, but it is the reign of God. This reign has already been inaugurated, by Jesus Christ, but will only be completed on his return. Thus the Kingdom is 'already/not yet' (Ladd 1959). Whilst acknowledging that full redemption, and hence the ultimate resolution of earthly problems such as poverty and injustice, will only come about when Jesus returns, integral mission theology argues that it is still important to work towards them and thus draw in the Kingdom into the present. ${ }^{3}$

The focus on Kingdom opens out redemption from the individual to the social and calls Evangelicals to look at the world around them and to be involved in its betterment. It is a radically different view to the mainstream premillennial dispensationalist theology that is predominant in many conservative Evangelical circles. 
And it has radically different implications regarding the value of social action in the world. From the viewpoint of premillennial dispensationalism it is understood that the fallen world will only get more and more depraved until Jesus comes back to bring a spiritual redemption for the saved. For these Evangelicals, still the majority, redemption is thus a personal matter and the focus of action in the world should be only to save souls so that they too get to participate in the ultimate redemption. Trying to improve life in the world, from the dispensationalist perspective, is both pointless and futile. Integral mission thus offers a radically different perspective.

In the late 1990s the leading Evangelical development NGOs tried to work out how to put this theology into practice in their overseas development work. World Vision led a series of meetings with practitioners to share ideas and experiences and chose to adopt the language of 'transformational development'. A few years later Bryant Myers, a member of Fuller Theological Seminary and a World Vision development practitioner, published Walking with the Poor (1999), a book about transformational development for the development worker from the perspective of World Vision. Around the same time Tearfund established a team of theologians and development professionals to develop a clear theological understanding of what would constitute a truly Christian development work (Freeman 2019). In 1996 this group launched Tearfund's 'Operating Principles' (Tearfund 1996), which set out its understanding of a distinctively Christian understanding of poverty and development, and in 1998, following the appointment of Rene Padilla as Tearfund's International President, they decided to adopt the language of integral mission.

In 2001 Tearfund was instrumental in establishing an international network of Evangelical relief and development NGOs with the express aim of promoting the vision and practice of integral mission. This network was named the Micah Network, taking its inspiration from the biblical passage Micah 6:8, which says, 'And what does the Lord require of you? To act justly, to love mercy and to walk humbly with your God'. It now has well over 500 members organisations and national networks in over 80 countries, all working to spread the idea of integral mission and to make it more mainstream. This has led to the concept of integral mission becoming widely accepted amongst Evangelical development NGOs and for the most part it now guides their approach to engaging in development work.

The shift to integral mission or transformational development had two major impacts on the development work of Evangelical NGOs. Firstly, it brought around a re-framing of this work from being a purely material matter to being a form of religious practice (see Freeman 2018, 2019). And secondly, in many cases it shifted their focus from large-scale projects to small-scale community development, in most cases in partnership with the local church. The new approach stressed that moving towards God's Kingdom required bringing about transformation at all levels - individual and social, spiritual and material. Thus transforming communities and 'restoring relationships' was seen to be central. Since local churches were seen as the basic unit of Christian society, and they were located 
within communities, it followed to integral mission thinkers that the local church that should be the agent of holistic community transformation:

[Integral mission] is fundamentally about restoring relationships - with oneself, with others, with God and with creation. Indeed, broken relationships are at the root of poverty, for poverty is the result of a social and structural legacy of broken relationships with God, damaged understanding of self, unjust relationships between people and exploitative relationships with the environment. The local church is at the heart of transforming these relationships.

(Raistrick 2010, p. 138)

And in this worldview evangelism and social action, or in more traditional Evangelical language, proclamation and demonstration, should not simply be combined, but it should be realized that they are actually part and parcel of the same thing. The Micah Declaration on Integral Mission states it thus:

Integral mission or holistic transformation is the proclamation and demonstration of the gospel. It is not simply that evangelism and social involvement are to be done alongside each other. Rather, in integral mission our proclamation has social consequences as we call people to love and repentance in all areas of life. And our social involvement has evangelistic consequences as we bear witness to the transforming grace of Jesus Christ.

(Micah Network 2001)

As the theology of integral mission has become more widely accepted in some sections of the Evangelical church, particularly in the UK and Australia, during the second half of the 20th century it has also become commonplace to see Evangelical churches engaging with their surrounding poorer communities and giving money to Evangelical development NGOs. Most UK evangelicals would now agree that engagement with issues of poverty is important. A recent survey by the UK's Evangelical Alliance found that the majority of UK Evangelicals now believe that evangelism and social action are equally important and that $85 \%$ say that their Church is currently engaged in social action with the local community (Alliance 2011; Green and Hewitt 2011, pp. 5-12). The Director of the Churches Team at Tearfund ${ }^{4}$ described the situation to me like this:

The UK church has been on a journey . . . about 15 years ago we were still having a lively debate about whether our faith was proclamation or works. We were still having that argument in the Evangelical church . . . people were still arguing amongst themselves about what the whole gospel was, about what the holistic gospel was. But I think that we have moved away from that debate now. There are really only a few people who would say 'no, no, no, it's only about proclamation'... I think the church has come to a settled place where they are saying it's both/and. . . . Now people are in that place where they believe that proclamation and works should go hand in hand. 
And the Head of Micah Australia described a very similar situation there:

At the start a theology of justice was not well developed amongst Evangeli-
cals at all. You had mainstream and liberal Protestant Christians and Catholics
really grappling to understand and engaging with links between justice and
faith. ... But you had the majority of the Evangelical church defining itself in
absolute opposition to that, because anything other than personal evangelism
is some sort of second order priority. . . But that has really shifted. I think
part of the shift has been some really intentional investments by particular
leaders in moving their congregations. For example Baptist World Aid has
played a really pivotal role inside the Baptist movement ... to help really
deepen that sense of justice at the heart of people's faith expressions. Early
on Tear were distinctive by saying 'we're the Evangelicals that care about
justice' and they were a small and beleaguered sect within their church com-
munities. But increasingly it's a mainstream concept.

Even in America there is an increasing trend for Evangelicals to get involved in social action with local poor communities and to give money to Evangelical relief and development NGOs working to alleviate poverty overseas (Reynolds and Offut 2014; Steensland and Goff 2014).

\section{Integral mission, advocacy and Jubilee 2000}

Once the theology of integral mission had become quite widely accepted in the Evangelical church in the UK and Australia, and to varying degrees in Evangelical churches in other countries, some Evangelical development NGOs started in the late 1990s to push for a deeper understanding of justice and for an extension of integral mission to focus not just on transforming communities, but to also look at transforming unfair global structures. They began to suggest that Evangelical development NGOs should also engage in political advocacy about the global and national structural issues that often underlie local instantiations of poverty. World Vision adopted a policy statement on advocacy in 1991 and now has an advocacy budget of around $\$ 7$ million. Other American Evangelical development NGOs, including Food for the Hungry, International Justice Commission and the Mennonite Central Committee now have offices in Washington and have also started to engage in political advocacy (Reynolds and Offut 2014, p. 247). In the UK Tearfund started advocacy and campaigning work in 1997 and currently has an annual advocacy budget of around $£ 4.4$ million, representing some $8 \%$ of their total budget (Tearfund 2015). Since then other members of the Tear family have developed advocacy programmes to greater or lesser extents. This move towards advocacy was partly a result of developments in Evangelical social thought and partly something that was influenced by the general shift of large secular international development NGOs towards an increased focus on advocacy around the structural issues affecting poverty and the beginning of their involvement in transnational advocacy coalitions to address global 
issues (Bryer and Magrath 1999; Fowler 1999; Hudson 2002; Rugendyke 2007; Yanacopulos 2015).

For the most part the advocacy carried out by Evangelical development NGOs since the late 1990s has been professional lobbying of politicians carried out by trained experts. ${ }^{5}$ However this changed in the UK and Australia when Evangelicals became swept up in the massive Jubilee 2000 campaign to cancel poor countries' debt that ran from 1996 to 2000. This campaign was initiated in the UK, with the support of both Christian and secular development NGOs and soon spread to over 60 countries. Its centre point was a petition calling for the cancelling of debts of the world's poorest countries, which was signed by 24 million people in 166 countries and was presented to UN Secretary General Kofi Annan at the UN Millennium Summit in 2000 (Pettifor 2006, p. 305). A key symbol of the campaign was the human chain, formed around various G8 summits and also around the World Bank, the IMF and several other sites of the global economy in the years leading up to the millennium.

The campaign was unusual because of its religious framing and the leading role of the churches. The Vatican, various national councils of Catholic Bishops, the Bishops of the Anglican Communion, the World Council of Churches and Evangelical churches associated with Tearfund were all involved. They utilized their extensive institutional networks of parishes, relief agencies, universities and lobbying organisations to support the campaign and call for debt relief for poor countries (Donnelly n.d., p. 20). The frame was rooted in the Judeo-Christian Book of Leviticus' prescription that at certain points in time economic relations should be re-set by freeing slaves, returning or redistributing land and wealth, and canceling debts. The centrality of the religious frame drew faith-based organisations to the forefront of the campaign and motivated and inspired a fairly establishment group of people to join with more radical activists to call for debt relief for poor countries.

In the UK the first key supporters of the campaign were Evangelical groups connected to Tearfund. Whilst the idea of a global campaign on debt seemed quite radical to them, and was certainly more radical than any of the issues on which they had campaigned before, if they had campaigned at all, they were fired up and excited by the Christian framing (Pettifor 2006, p. 299). Stephen Rand, then Prayer and Campaigns Director for Tearfund and one of the people who a few years later would be foundational in the inception of the Micah Challenge, explained to me:

[The Jubilee framing] was enormously significant for the Tearfund constituency because they bought into the biblical argument quite strongly. That was the rolling tide that bought the Evangelical constituency into that movement.

Tearfund was the first major British NGO to send out a circular to its supporters asking them to donate to the Jubilee 2000 campaign, and a few years later Tear Australia led the formation of Jubilee 2000 Australia. In other countries Protestant and Catholic groups were more central in organizing Jubilee 2000 coalitions and 
Evangelicals played a far smaller role, if they were involved at all (Donnelly n.d., p. 15; Friesen 2012, pp. 58, 65; Pettifor 2006, p. 300).

In the UK churches hired buses to take their congregations to the demonstrations around the G8 in Birmingham, and church-goers that I interviewed spoke of the wonderful excitement of heading up to Birmingham together, singing hymns on the way. A senior Tearfund staff member told me:

People from my own church turned up at the demonstration in Birmingham. And they'd never been to a demonstration before in their lives. We didn't call it a demonstration, of course, it was human chain.

Across the UK Jubilee 2000 activities became part of churches' celebration of the millennium, along with parish parties and fireworks (Reitan 2007, p. 77). For many Evangelicals campaigning for debt reduction became a deeply meaningful religious experience. Stephen Rand describes a prayer vigil that was held in his Baptist church during the 2000 G8 meeting in Okinawa, Japan:

The G8 leaders were in Okinawa. A small group of us were in a West London church. As we followed the Summit Watch vigil guide I realized that this was not just a routine ceremony. It was another step of faith; on a path that for many had included Birmingham and Cologne, the petition clipboard on the village green and outside the polling booth, the postcards and letters sent to [Prime Ministers] Tony [Blair] and Gordon [Brown] and the Japanese Embassy. As the vigil ended we were invited to light a candle, and place it at the front of the church. At first no-one moved. Then, in deep silence, one and another solemnly took their candles forward. The silent movement spoke eloquently of commitment, of determination, of faith, of hope. The candle flames flickered, as the highest aspirations of the human spirit were fueled again by God's compassion and justice. The spirituality at the heart of Jubilee 2000 had never felt so powerful.

(Stephen Rand, quoted in Barrett 2000, p. 19)

As well as bringing about a certain amount of debt cancellation, Jubilee 2000 had a profound effect on the Evangelical church in the UK. It educated a large number of Evangelicals about one of the most fundamental structural issues underlying global poverty and it made campaigning and advocacy something that was acceptable, and indeed important. A survey in 2011 found that 94\% of the UK's Evangelicals now thought that Christians should engage with government (Alliance 2011; Green and Hewitt 2011, pp. 5-12). Stephen Rand explained the sea change to me like this:

From Jubilee 2000, from say 1997 to 2005, and I think because of Jubilee 2000 largely, the Evangelical constituency broadly moved into acceptance of political campaigning. That's a whole load of individual journeys, but it's also about the tone and it's about what church leaders are saying. And I think 
more and more church leaders, the ministers in the pulpit, would be positive about signing petitions and all of those things. . . I'd like to think that Tearfund itself, and the involvement in Jubilee 2000, significantly shifted the Evangelical constituency towards an understanding of concern for the poor ... including campaigning for change.

Evangelicals in Australia went through a similar transition and also came to accept campaigning and advocacy. In other countries, however, where Evangelicals had been far less engaged with the Jubilee 2000 campaign, this transition did not take place. One of the aims of the Micah Challenge, which was being discussed in the UK already in the early 2000s, was to spread this new Evangelical engagement with advocacy for the poor to the rest of the global Evangelical church. Stephen Rand, who as pivotal in those early discussions, explained to me:

The context was very different [in other countries], because once you've got that sea change in the UK where the predominant wave is that this campaigning stuff for third world poverty is acceptable, in a sense you don't have to make the argument any more. . . . I think the challenge for Micah Challenge was that in many countries that battle hadn't been fought.

Joel Edwards, another one of the initiators of the Micah Challenge and later its Director, echoes the same sentiment:

Globally was a very different picture from the UK. In a way we were trying to take the UK context and spread it globally. We were trying to use the muscle of the experience [of Jubilee 2000] . . . and that's why the UK, and to some extent Australia, were real engine rooms for what Micah Challenge was seeking to do globally. . . . Europe and other parts of the world were way behind in advocacy, way behind.

\section{The Micah Challenge}

As the Jubilee 2000 campaign was beginning to wind down, Joel Edwards, then Director of the Evangelical Association UK, and Stephen Rand, then Campaigns and Prayer Coordinator at Tearfund, started to talk about the idea of a global Evangelical advocacy campaign for the poor. They wanted to build on the Jubilee 2000 experience and make advocating for justice a core part of the work of the global Evangelical church. When they heard about the new Millennium Development Goals (MDGs), ratified by most countries at the UN Millennium Summit in September 2000, they thought this would be a good basis for their campaign. Joel Edwards explained:

When we heard of the MDGs we thought 'Incredible! These eight promises are historic. They reflect the promises of the prophets about justice'. And if 
governments are holding themselves accountable to the poor, why should we not as the church get behind such promises and seek to mobilise Christians globally, particularly Evangelicals.

In May 2001, as a way of testing these ideas within the wider global Evangelical community, Stephen Rand crafted a resolution on global poverty and the MDGs and presented it at the World Evangelical Alliance (WEA) in Kuala Lumpur, Malaysia. ${ }^{6}$ It started with the words:

As a global Christian community seeking to live in obedience to Scripture, we recognise the challenge of poverty across God's world. We welcome the international initiative to halve world poverty by 2015 , and pledge ourselves to do all we can, through our organisations and churches, to back this with prayerful, practical action in our nations and communities.

The resolution was the first of its kind at the WEA and Rand and his colleagues were delighted when it passed. It marked a new openness from the WEA to actively engage in worldly matters, including political advocacy for the poor. From 2001-2003, discussions continued between the UK's Evangelical Alliance, the World Evangelical Alliance, Tearfund and the Micah Network about the possibility of organizing a global Evangelical campaign against poverty. After long discussions, it was eventually decided that the campaign should be a collaboration between the Micah Network and the World Evangelical Alliance, that local Evangelical churches should be mobilized to advocate to their governments, and that the MDGs should form the central framework. According to Joel Edwards:

Micah Challenge was perceived as the campaigning bit of the Micah Network family, so that Micah Network would do integral mission and be a term of reference for emerging NGOs. Micah Challenge would be a specific campaigning arm, which had never happened before. And it would be a global campaigning arm which would draw on the intellectual property and the expertise of the NGO world and blend that with church, which is why at the very beginning Micah Challenge became the child of Micah Network and the WEA.

From the very beginning the aim was to fit advocacy work into the overall approach of integral mission. One of the key elements of this was that it would be the local churches that would carry out the advocacy and campaigning, and that it would become part of their religious practice. ${ }^{7}$ The Director of the Micah Network, who was also on the Board of the Micah Challenge, explained it to me like this:

They said this was a tremendous achievement, for the world to agree on these eight goals, let's use that momentum and see how we can, through our integral mission lens, try to mobilise churches to take their responsibility. 
Thus the aim was never to establish an expert-led advocacy department where professionals met with politicians and lobbied them about various issues. The aim was always to transform the church and to get it and its members to engage in popular advocacy and campaigning as part of the living out of their faith. Joel Edwards explained:

A very important part of our work was raising the consciousness .... and mobilising a section of civil society called the Evangelical church. . . Changing the churches was the key part of it. Sensitising the churches. Sustainable long term engagement and paradigm shift was the idea . . . [We wanted to take] advocacy and build it in as integral to our Christian witness.

The Micah Challenge campaign was officially launched at the UN on 15 October 2004 and ran until 2015, when the deadline for the accomplishment of the MDGs was reached. It had two stated objectives: (1) to provide the global Evangelical community with a means of influencing national and international policies affecting key areas, and (2) to significantly increase the involvement/ action of Evangelicals in favour of the poor (Edwards 2008, p. 7). In 2004 it issued the Micah Call, a statement of the vision and values of the campaign, and which it asked individuals and church leaders to sign to show their support. The call set out the prophetic vision of the church, made mention of holistic transformation and referred to the key biblical passage from Micah 6:8. It also called on Christians to play their own part in working for the poor, as well as asking them to hold their national leaders to account for achieving the MDGs.

This is a moment in history of unique potential when the stated intentions of world leaders echo something of the mind of the Biblical prophets and the teachings of Jesus concerning the poor, and when we have the means to dramatically reduce poverty.

We commit ourselves, as followers of Jesus, to work together for the holistic transformation of our communities, to pursue justice, be passionate about kindness and to walk humbly with God.

We call on international and national decision-makers of both rich and poor nations, to fulfil their public promise to achieve the Millennium Development Goals and so halve absolute global poverty by 2015 .

We call on Christians everywhere to be agents of hope for and with the poor, and to work with others to hold our national and global leaders accountable in securing a more just and merciful world 
The basic structure of the campaign was an international secretariat of three to four people, based in London, and then national campaigns based in other countries in both the North and the South. Each national campaign had a coordinator, and occasionally a few other staff or interns. The global secretariat was overseen by a board, whose members came from both the Micah Network and the WEA. A similar structure was set up for each of the national campaigns, where a steering committee was set up with both NGO staff and people from the local Evangelical Alliance or the local Evangelical churches.

Initial conversations were held in 63 countries regarding getting involved in Micah Challenge and national campaigns of varying capacities were set up in 41 countries (Winter and Woodhead 2014, pp. 26-28). In some countries the coordinator was based in the office of a local Evangelical development NGO, often Tearfund, while in other countries they would be based in the office of the local Evangelical Association. The idea was that each national campaign would look at the situation regarding the MDGs in their country and would decide what specific issues to lobby their governments on to ensure that the MDGs were reached. It was hoped that the NGOs would bring expertise in development matters and policy issues and would develop specific policy asks which church leaders and members of the local churches could then campaign on. The international secretariat would support the national campaigns by providing resources, training and inspiration and would also organise a number of 'global moments'. These included Micah Sunday, which would take place on the Sunday closest to the International Day of Poverty in October, and three global campaigns in which all of the national campaigns would be invited to participate as the global church.

Mobilising the national campaigns, however, proved to be extremely difficult. There were a number of challenges. In many cases the national coordinators were young and inexperienced and there was often a lack of adequate funding. In other cases the local Evangelical Alliance was poorly organized and did not represent many of the Evangelical churches in the country. And in many countries in the global South it was difficult to do national level policy advocacy with undemocratic governments. Notwithstanding these practical challenges, the most serious challenge proved to be one of theology. While the Micah Network had already been working for a few years to promote Evangelical social engagement through the theology of integral mission, and was seeing some shifts in attitude, by far the majority of global Evangelicals still followed the premillennial dispensationalist theology and thus did not believe that they should engage with worldly matters, let alone politics, and instead should focus on saving souls. This challenge was found in virtually every country in which the Micah Challenge worked. To give but two examples, the Coordinator of Micah Challenge Switzerland explained it to me like this:

It was difficult to create a movement inside of the Church. . . . They look at me and say 'but that's how it is. Jesus says that the world will go down and he will create a new earth, so why should we bother about the earth?' ... This theology in the head of people is one of the biggest problems. 
And the coordinator of Micah Challenge India relayed similar issues:

Lots of people were not convinced and raised questions. They said we would be diverting our attention and energies towards helping the poor but we are going to leave this world and have permanent abode of heaven, so we don't need to be worried about this. The government has the responsibility, if the government doesn't do it, why should we be worried about it? It will be unnecessarily diverting out attention from preaching the gospel to other things.... I had a lot of arguments like this.

A member of the international board summed up the global situation like this:

$90 \%$ of [the Director's] work was trying to win the argument with the churches. So he did a lot of raising awareness, but he had very few lobbyists. To move them to the actual lobby-campaign mindset was very hard. He first had to win a theological argument, in the church, that the church should be in politics. And that is a very hard one.

The rest of this chapter looks at the way that the Micah Challenge sought to win this theological argument to convince Evangelicals around the world that advocacy for the poor was biblical and Godly, and thus to mobilise them to get involved.

\section{Mobilising Evangelicals for development advocacy}

Whereas integral mission, or transformational development, provides a theology of development to guide the development work of Evangelical NGOs, Reynolds and Offutt have argued that Evangelical engagement with advocacy around poverty issues has been hampered by the lack of a coherent underlying theology (Reynolds and Offut 2014, p. 249). Evangelical scholars have made similar claims (e.g. Davis 2009; Thacker 2015). ${ }^{8}$ It is thus significant that the Micah Challenge tried to take the first steps towards developing such a theology.

\section{Justice is Biblical}

The first step in developing an Evangelical theology of justice was to persuade Evangelicals that justice was biblical and central to God's plan for the world. So the Micah Challenge team produced a lot of materials discussing the sections of the bible that deal with justice and showing its centrality in the bible, including the books Micah's Challenge (Tresser 2009) Just Mercy (Edwards 2010) and Live Just.ly (Fileta 2014), the Jesus Agenda DVD and study guide (McLachlin and Edwards 2012), and a number of shorter booklets, articles and blogposts. These publications mainly dwelt on the teachings of the Old Testament prophets and on Jesus's ministry in the New Testament. The Micah Challenge team sought to show the centrality of justice in the bible and to highlight the fact that many churches 
were avoiding large sections of the bible in their sermons and teachings. The Director of Micah Challenge wrote in Just Mercy:

After idolatry, God says more in the Bible about injustice than any other subject. But, even so, many of us who have attended church for decades can still count on our fingers and toes the number of Sunday sermons we have heard on justice.

(Edwards 2010, p. 10)

In many churches round the world pastors would preach about the personal attributes of righteousness and holiness, but would ignore the more systemic issue of justice. The Micah Challenge team sought to connect these three elements and thus bring justice back into the picture. As Stephen Rand explained to me:

Right wing Americans tend to be quite strong on righteousness. ... When I preached, it would be that justice and righteousness is about doing the right thing. The bit about justice tends to be the public sphere, and doing the right thing in your family or in your street tends to be regarded as righteousness and morality.

In Just Mercy (2010), the International Director defines justice as 'righteousness responding to wrong' and tries to make the theological argument that righteousness, holiness and justice must be considered together. Building on the integral mission approach, which seeks to open out people's focus from the personal to the social, he argues that righteousness, holiness and justice are all fundamentally social, rather than personal, attributes:

The Bible makes no distinction between God's justice, which redeems us at the cross, his holiness, which we share, or his Righteousness, which we display. Justice is the river that flows from the heart of God, responding to our sin and sinfulness in all its private and public manifestation. A theology that puts a wedge between personal holiness and prophetic advocacy uses the Bible to build a dam in that river.

(Edwards 2010, p. 11)

And again in the study guide accompanying the Jesus Agenda DVD:

In much of our teaching holiness is typically moralized or privatized, but there is nothing more central to the Scriptures that describes everything from our relationship to God, our communal behavior and justice. Biblical holiness is far bigger than human sexuality, piety or personal morality. It empowers us to tackle two giants of oppression to humanity: materialism and corruption. This study encourages us to consider holiness, righteousness and justice in an integrated way. 
In the integral mission approach biblical justice is seen as being restorative - it is about restoring the world to the way that God created it, restoring it to a state of 'shalom'. In a piece called The Message of Micah, a member of the steering committee of Micah Challenge Australia (who was also on the International Board) writes:

Biblical justice is incredibly comprehensive in its requirements and consequences. Biblical justice is a restorative function - affirmative action on behalf of the powerless to restore their proper (meaning God-ordained) position in human society. It is concerned with fair wages and fair trading, with equality under the law so that there is not one law for the rich and wellconnected, and another for the poor and marginalized. Biblical justice is about ensuring that the weak have access to all that which is needed to play a full and dignified role in human society, to experience life as God intended it to be. Biblical justice is a consequence of the fact that all men and woman are created in the image of God, and equally loved by him. Along with love justice is absolutely fundamental to biblical ethics.

(Bradbury 2011)

The International Campaigns Manager explained to me how she would apply this biblical concept of restorative justice to the MDGs, about which they were campaigning:

When we talk about poverty, the MDGs, which was the underpinning of the campaign, there was a sense that poverty wasn't just a personal choice or an accident, but it was the result of structures in the global economic and social system that kept people away from opportunity, from equity, and that these things made God angry, that God had always been angry about injustice. And that justice was about access to that sense of wellbeing and restoration and peace that is summed up by tzedek, I suppose, in the Old Testament. And justice was much more than 'this is right, or wrong', it was the sense of restoration, equity and opportunity and hope to those people, for various reasons, didn't have those things.

Furthermore, the Micah Challenge team felt that it was important to emphasise that justice was something quite different from charity. Whilst giving help or money to those in need was all well and good, they tried to communicate that there were systemic problems that were causing many people to live in poverty, despite their own choices and actions, and that therefore it was important to also lobby governments to change these bigger systemic problems in order to bring about justice and restoration, and ultimately, the Kingdom of God. The International Campaigns Manager explained it to me like this:

[The framing] was very much justice. We were working with lots of supporters who would start from a charity perspective, 'I am blessed so I should 
bless others', or 'there is so much unhappiness in the world, I should be contributing to make the world a better place'. These are very valid places to start, but we would say it was also a matter a justice, that God was a God of justice, ... tell them how people stood up against injustice, how they acted. And we would use those examples - Esther, Nehemia, daughters of Zelophehad, you know, the whole thing to show that this was a Biblical concept. And that it wasn't just charity and sympathy, but that I guess God wanted us to bring in the Kingdom of God more on Earth, and the Kingdom of God was the Kingdom of Justice.

\section{Advocacy is not politics}

The team had to walk a fine line between talking about biblical justice and the Kingdom of God and then translating this into the practical action which they were seeking, namely advocacy to governments about the MDGs. If it sounded too political then people would pull away. The Coordinator of Micah Challenge Australia explained to me:

When you try to invite people to look at the systems that bind people and constrain choices and options ... it's not something we are in the habit of doing and it can be threatening because it feels like an alien political agenda being imposed on a church group or an organisation.

Similarly, if things began to sound too political many Evangelicals would get worried that they were losing their focus on what was actually the most important thing - saving souls. This issue would come up again and again, in pretty much every country where the Micah Challenge worked. The Coordinator of Micah Challenge USA gave me this example:

There was a guy who spoke at one of our events, and he was like 'the Millennium Development Goals are great, but they won't get you into heaven. So let's not lose sight of proclaiming the gospel of Jesus Christ'. He wasn't actually responding to anything we said, he was more responding to what he knew people were afraid of, which was that we would lose sight of the Gospel.

And thus the team had to put a lot of effort into convincing people that engaging with justice and advocacy was not 'politics', but that it was religious action. They sought to convince people that advocating on behalf of the poor was part of their living out their faith. Thus the Coordinator of Micah Challenge USA continued:

Part of that was that he didn't understand that for us this was part of the Gospel. So we weren't losing sight of the Gospel, we were preaching a more inclusive and encompassing Gospel that actually had ramifications for this life, not just the next. 
This theme is a clear extension of the integral mission theology to include justice and advocacy and it permeated most of the Micah Challenge publications and communications. It can be seen very clearly in the Just Mercy book, where the International Director writes:

Justice isn't politics. It's far more than that. Justice is righteousness responding to wrong. And this means that doing justice is central to the Christian faith. ... God's justice is more than a message. It's God's mission to a broken world.

(Edwards 2010, pp. 11-12)

However, in order to convince Evangelicals to take the step from caring about justice to actually engaging in advocacy it was also necessary to develop a theology of advocacy. Again, the starting point was the bible, and much of Micah Challenge's early writings on advocacy focus on biblical examples of advocacy. Many of the publications focus on the Old Testament prophets, particularly on Micah, Isaiah, Hosea who pointed out the injustice and corruption in the Israelite kingdoms, or on Esther, who is hailed as a biblical character who did advocacy with King Ahashverosh, or on Moses who is said to have done advocacy with Pharoah. In all these texts, advocacy is presented as something that is solidly biblical and profoundly Godly.

Esther's story, told in the biblical book that takes her name, is a vivid reminder that advocacy is one of the most powerful tools God has given us to combat oppression and injustice.

(Micah Challenge Australia 2011)

It was emphasized again and again that advocacy was not political, but rather a way of living out faith. It was seen as a profoundly religious action, partnering with God in his work of redemption.

Christian witness is growing increasingly to encompass not only practical action but also prophetic advocacy for the poor. Advocacy - speaking up for the poor - takes us a step beyond practical action to prophetic engagement. Quite frankly, it's not something we are always comfortable in doing. It looks on the face of it to be nothing more than political activism. However, there is a world of difference between political activism for ideological reasons and speaking to the powerful with and on behalf of the poor in the name of Christ. When Moses stood before Pharaoh and said 'Let my people go!' this was advocacy. . . . It does not come from political conviction but is the overflow behavior of people who walk in biblical humility and who love mercy. . . . Our advocacy is neither the easy nor the political option, but it is what righteousness demands.

(Edwards 2010, pp. 50-51) 


\section{Advocacy as religious action}

Across the Micah Challenge it was felt that in order to convince Evangelicals to do advocacy it was necessary to turn advocacy into a personal religious action. A new type of 'lifestyle advocacy' was developed across the Micah world. It was formulated most explicitly in the USA, under the name of 'transformational advocacy', but the general ideas and approach were used across the movement. The International Director also developed a charismatic theology of advocacy inspired by the Holy Spirit to reach out to Pentecostals and Charismatics. Both approaches sought to shift advocacy from being purely a dry matter of dealing with impersonal structural factors into a more personal activity that linked also with lifestyle, holiness and religious experience.

Activists in some parts of the movement worried that traditional advocacy felt very secular and disconnected from their other religious activity. The coordinator of Micah Challenge USA explained it to me like this:

We felt like traditional advocacy wasn't working as far as it didn't really connect with the church. ... We realised that there wasn't any personal aspect to it. So I'd go to these churches and these college campuses and try to inspire people and get them to change their whole way of thinking about their lives. And then to say, 'just keep living the same way you always lived but write a letter to Congress' and so on, that just felt really empty to me.

And so, in collaboration with some other Evangelical development NGOs, they developed the concept of 'transformational advocacy'. As transformational development was to regular development, so transformational advocacy would be to regular advocacy. Transformational advocacy would be holistic religious action. It was something done by Christians, as Christians, and in a deeply Christian way. One of the main ways that transformational advocacy differs from traditional advocacy is that it has a personal morality and holiness lifestyle element to it and it includes a focus on the person doing the advocacy. Thus transformational advocacy widens out the concept of advocacy to include not just policy change, but also the behaviour change of individuals. The goal of transformational advocacy is 'changing attitudes, policy and behaviours that perpetuate injustice'. With this formulation it becomes important that the person advocating must also be working on their own personal righteousness and living justly themselves. In an interview on an Evangelical website the coordinator of Micah Challenge USA put it like this:

Transformational advocacy is the process of challenging ourselves and our leaders to change attitudes, behaviors, and policies that perpetuate injustice and deny God's will for all creation to flourish. . . . Transformational advocacy recognizes that there are systemic injustices that must be challenged in order to see God's intention for all creation to flourish, but also recognizes 
that we can't ask our leaders to do something we ourselves aren't willing to do. We can't ask for integrity, generosity, justice, and compassion from our leaders if we too don't embrace them in our hearts and actions. This differs from traditional advocacy which focuses on changing policy without recognizing the logs in our own eyes so to speak. Traditional advocacy also tends to create an 'us vs. them' mentality when engaging people of power - transformational advocacy recognizes that we are all guilty before God for the sins of injustice, and we are all invited to be a part of God's solution to bring healing in the world (Fast. Forward. The End of Poverty).

Furthermore, transformational advocacy could also provide a new route through which Evangelicals could proclaim the glory of God to new groups of people. Transformational advocacy is holistic and it therefore has a spiritual component to it. As religious action transformational advocacy could be both a form of worship and a form of proclamation. The coordinator of Micah Challenge USA explained it like this in an educational video on the Micah Challenge USA website:

This is the beautiful work of advocacy. And we do it as worship, we do it to glorify God. God takes joy when His people stand up and speak out against unjust policies . . . and hold their leaders to account to a higher standard. ... When we do that we don't take off our Christian faith, we don't take off our identity as followers of Jesus. We bring that with us, into these places which are often secular, into these places where conversations about faith are uncomfortable. We bring who we are into these places, we bring Jesus into the room. . . . Advocacy is a way that we tell the world about who our God is. We proclaim that God is a God of justice, that his concern for the vulnerable, for the oppressed, for the marginalized is so great that we, his followers, can't help but speak out. When the world hears of our God who is deeply concerned about the lives of people who are marginalized, who is deeply concerned about how policies impact the poor, they'll take notice. . . Advocacy is a chance for us to tell the world about who our God is.

The International Director further built on these ideas and sought to reach out to Pentecostal and Charismatic Evangelicals, who very much focus on the role of the Holy Spirit in their lives, and who constitute a substantial proportion of the global Evangelical church, particularly in the global South (Anderson 2004; Freeman 2012; Martin 2002). As a British black Pentecostal, with roots in the Caribbean, he himself was motivated by the experience of the Holy Spirit in his life. And thus he sought to develop a theology of advocacy that made a direct connection between the intense spirituality that Pentecostals and Charismatics experience in their ecstatic worship and the act of political advocacy. He based this theology on the story of Moses who, according to the bible, was persuaded to advocate to Pharaoh on behalf of the Israelites during an intense episode at the burning 
bush where God appeared to him and directly commissioned him for the task. He explained to me:

Advocacy is what the Holy Spirit does on our behalf. This appeal to God on our behalf. So the notion of advocacy is already there. We used Moses quite a lot, we like Moses as a paradigm for advocacy - God meets him at the burning bush, at the place of worship, and it's at the place of worship that he is commissioned to go to Pharaoh. That's high grade, it doesn't get any higher than that in advocacy. And so what we tried to do, especially when talking to the church, was to build a theological line of continuity from worship at the burning bush to commissioning to go to Pharaoh's house. Our argument was based on ... [the idea that] you cannot start off at the burning bush and not find your way to Pharaoh's house.

This theology was developed in the Jesus Agenda DVD, which 'asks how the liberating power of the Spirit should lead 21st century Christians to become advocates of the poor' (McLachlin and Edwards 2012, p. 3), and again in the Use by 2015 booklet that was brought out in the same year. The key theme was that spiritual experiences of the divine should lead people to activism on behalf of the poor. The call to advocacy is framed as a deeply personal and intense religious experience. And if you have such an experience, then you must play your part in response and let the Holy Spirit drive you to engage in advocacy for the poor. Framed this way, advocacy for the poor is not simply political activism, it is something that is driven by spiritual forces and the experience of God. It is deeply religious action. Use by 2015 puts it like this:

Moses' journey which began at the burning bush ended up in Pharaoh's palace where he found himself advocating for the freedom of the Hebrew slaves. ... What fuelled Moses' passion was neither egotism nor a political philosophy: it was the mandate of the burning bush. That's where it began. For God who called him to draw near without his sandals and sent him striding into the palace. Afraid and on a steep learning curve Moses became God's first biblical advocate for justice. .. Those of us who hunger for a Moses experience at the burning bush should walk with him to Pharaoh's house.

(Micah Challenge International 2012, p. 10)

\section{From theology to mobilisation}

Taken together, the theological writings of the Micah Challenge go some way to developing an Evangelical theology of justice and advocacy. But it would be fair to say that this task is still to be completed. In their effort to make advocacy palatable to Evangelicals, Micah Challenge found it necessary to emphasise personal morality and spiritual experience and in doing so they tended to lose sight of the larger structural issues that they were trying to address. In all the writings of Micah Challenge there are very few references to global political and economic 
issues such as trade or debt or structural adjustment programmes, and there was no analysis of how systemic global factors lead to poverty for many people in the world. While much effort was spent trying to convince Evangelicals that it was appropriate and biblically sanctioned for them to engage in justice advocacy for the poor, much less energy was invested in analysing the causes of contemporary global poverty and thus in suggesting precisely for which policies and practices they should actually be advocating.

This may be part of the reason why the Micah Challenge did not really succeed in carrying out very much advocacy. While the Micah Challenge campaigns in the Northern countries did a small amount of lobbying and campaigning, mainly focused on asking for an increase in their country's aid budget, the campaigns in the South chose mainly to focus on educating Evangelicals about poverty and advocacy and in some cases carrying out direct practical action on behalf of the poor. The global campaigns motivated millions of Evangelicals to pray for the poor, but only a few thousand went further to talk to parliamentarians, to write letters to their MP or to march in the streets.

Australia was the exception. ${ }^{9}$ There Evangelicals had already been persuaded about the acceptability of advocacy through their experience in the Jubilee 2000 campaign. With the theological battle already won, Micah Challenge Australia succeeded in bringing Evangelicals to Canberra each year to talk with their parliamentarians about global poverty. They campaigned on a variety of issues connected to the MDGs, including maternal health, child health, water, sanitation and hygiene, climate change and environmental sustainability. They also did a number of creative public engagements. For example they organised a Giant Toilet tour, where they toured around the country with a huge $2 \mathrm{~m}$ high toilet and then parked it outside Parliament House, in a campaign about water and sanitation. And they organised 'Survive Past Five' birthday parties, which were held in churches to celebrate increases in rates of childhood survival, and after which congregants were encouraged to write to a member of parliament about the issue.

But in most countries there was very little policy analysis and very little political mobilisation. Evangelicals began to think about justice and poverty, and many started to pray for the poor. But very few actually took the step to engage in political advocacy. This is still an ongoing process, and things may change in the coming years. At the end of 2015 the Micah Network and the Micah Challenge merged to form Micah Global. National Micahs continue to operate in many countries, bringing together Evangelical development NGOs and local churches. As well as working to spread the idea of integral mission they plan to continue working on mobilising the local churches to engage in justice advocacy for the poor. So whilst the Micah Challenge has now come to an end, the process of shifting the Evangelical churches into an engaged justice mindset is still very much ongoing.

\section{Conclusion}

This chapter has looked at recent developments in Evangelical thought and action regarding social engagement, and particularly regarding engagement 
in political advocacy around issues of justice and poverty. It has shown how the Micah Challenge, the first transnational Evangelical advocacy campaign for the poor, has been working to try to bring about a major change in Evangelicalism, to open it out into a form of religion which holistically unites the personal and the social, the spiritual and the material, the moral and the political. Whilst this process is far from complete and is often met with resistance in many quarters of the global Evangelical world, it is slowly and gradually having an impact and bringing about a shift in Evangelical theology and religious practice.

In particular this chapter has shown how certain sections of the Evangelical world, particularly those engaged in international development work, are deepening their interest and involvement in global social issues and are working to develop an Evangelical theology of justice and advocacy. Whilst many of the concepts in this theology bear resemblance to those developed in the mainline ecumenical world many decades earlier, they are being translated into a 'lifestyle' practice that is quite distinctive. This study has shown how the Micah Challenge was instrumental in developing much of this new theology, and in spreading it to Evangelicals in many countries in both the global North and South. As such, it is possible to see the Micah Challenge as a development entrepreneur.

There have been many tensions in this attempt to engage global Evangelicals in social action and political advocacy on behalf of the poor, and in this chapter I have shown how the Micah Challenge sought to mediate between different discursive fields in order to create a nexus between its evangelical constituency and the field of international development (Koehrsen and Heuser 2019 this volume). It did this by seeking to overcome the divide between the personal and the social, the inner-worldly and the outer-worldly, and the religious and the secular. I have argued that it was not completely successful in overcoming these divides and that ultimately it faced a paradox which it could not overcome - that to make justice and advocacy palatable to Evangelicals it had to emphasise personal morality and spirituality, and yet in doing so it lost focus on the global political and economic issues that it wished to raise.

Nonetheless the Micah Challenge, and all the churches and NGOs that supported it, represent a major sea change in Evangelical thought and action around social justice, and it seems likely that this change will continue developing in the Evangelical world in the coming years.

\section{Notes}

1 Research for this chapter was carried about between September 2015 and November 2016 and consisted of interviews with present and former members of staff of the Micah Challenge and Tearfund and brief periods of ethnography at Micah meetings in London. UK interviews were carried out face-to-face, while interviews with staff in other countries were carried out over Skype. This was supplemented by an analysis of internal and publically available documents, writings on Evangelical websites, and a review of the relevant academic literature. 
2 The word 'transformation' was also chosen in contrast to the word 'liberation', which Catholic and ecumenical Protestants had chosen instead of 'development' (Tizon 2011, p. 69).

3 Many of these theological ideas are similar to those in mainline Protestant ecumenical circles.

4 All interviewees are referred to by their job title at the time of the interview. To respect privacy, personal names are not mentioned, with the exception of public figures who are widely known to have held a particular role.

5 Tearfund is the notable exception here and it has been trying to educate and mobilise Evangelicals in the UK to engage in popular advocacy and campaigning since the late 1990s. For a detailed study see Freeman 2019.

$6 \mathrm{Up}$ to this point it was called the World Evangelical Fellowship, but from this meeting onwards it changed its name to the World Evangelical Alliance (WEA).

7 This is very different to the approach of the World Council of Churches, which has a strong advocacy department, but where advocacy is carried out by expert professionals and not by local churches.

8 But see Gordon (2002) for Tearfund's approach to advocacy.

9 Micah Challenge UK had different problems. There Evangelicals were already doing advocacy through Tearfund and many also supported the ecumenical Christian development NGO, Christian Aid, and even the large secular NGOs such as Oxfam and ActionAid. The field was therefore already rather full and there was some competition between the various organisations. Thus Micah Challenge UK was only active from 2006-2010 and never managed to become significant in the UK Evangelical scene.

\section{References}

Anderson, A.H., 2004. An Introduction to Pentecostalism. Global Charismatic Christianity. 1st ed. Cambridge: Cambridge University Press.

Barrett, M., 2000. The World Will Never Be the Same Again. London: Jubilee.

Bebbington, D.W., 1993. Evangelicalism in Modern Britain. A History from the 1730 s to the 1980s. London: Routledge.

Bialecki, J., 2008. Between Stewardship and Sacrifice: Agency and Economy in a Southern California Charismatic Church. Journal of the Royal Anthropological Institute, 14 (2), 372-390.

Bialecki, J., 2009. Disjuncture, Continental Philosophy's New "Political Paul," and the Question of Progressive Christianity in a Southern California Third Wave Church. American Ethnologist, 36 (1), 110-123.

Bielo, J.S., 2011. Emerging Evangelicals: Faith, Modernity, and the Desire for Authenticity. New York, NY: New York University Press.

Bielo, J.S., 2014. 'Formed': Emerging Evangelicals Navigative Two Transformations. In: B. Steensland and P. Goff, eds. The New Evangelical Social Engagement. New York, NY: Oxford University Press, 31-49.

Bradbury, S., 2011. The Message of Micah [online]. Available from: http://d3n8a8p ro7vhmx.cloudfront.net/micahaustralia/legacy_url/188/The_Message_of_Micah_-_ Steve_Bradbury.pdf?1444111417 [Accessed 25 July 2017].

Bryer, D., and Magrath, J., 1999. New Dimensions of Global Advocacy. Nonprofit and Voluntary Sector Quarterly, 28 (1), 168-177.

Carpenter, J., 2014. What's New about the New Evangelical Social Engagement? In: B. Steensland and P. Goff, eds. The New Evangelical Social Engagement. New York, NY: Oxford University Press, 265-279. 
Clarke, G., 2008. Faith-Based Organizations and International Development: An Overview. In: G. Clarke and M. Jennings, eds. Development, Civil Society and Faith-Based Organizations. Bridging the Sacred and the Secular. Basingstoke, New York, NY: Palgrave Macmillan, 17-45.

Clawson, M., 2012. Misión Integral and Progressive Evangelicalism: The Latin American Influence on the North American Emerging Church. Religions, 3 (3), 790-807.

Davis, R., 2009. What about Justice? Toward an Evangelical Perspective on Advocacy in Development. Transformation, 26 (2), 89-103.

Ditchfield, G.M., 1998. The Evangelical Revival. London: Routledge.

Donnelly, E.A., n.d. Proclaiming the Jubilee: The Debt and Structural Adjustment Network. Case Study for the UN Vision Project on Global Public Policy Networks [online]. Available from: www.worldhunger.org/articles/hn/debtcrisisnet.pdf [Accessed 30 April 2018].

Dreher, S., and Smith, P.J., eds., 2016. Religious Activism in the Global Economy. Promoting, Reforming, or Resisting Neoliberal Globalization? London, New York, NY: Rowman \& Littlefield International.

Edwards, J., 2008. The Story So Far. In: J. Thacker and M. Hoek, eds. Micah's Challenge: The Church's Responsibility to the Global Poor. Milton Keynes: Paternoster.

Edwards, J., 2010. Just Mercy. Surrey: CWR and Micah Challenge International.

Elisha, O., 2008. Moral Ambitions of Grace: The Paradox of Compassion and Accountability in Evangelical Faith-Based Activism. Cultural Anthropology, 23 (1), 154-189.

Elisha, O., 2011. Moral Ambition: Mobilization and Social Outreach in Evangelical Megachurches. Berkeley, CA: University of California Press.

Evangelical Alliance, 2011. 21st Century Evangelicals: A Snapshot of the Beliefs and Habits of Evangelical Christians in the UK. Retrieved 16 January 2013.

Fast Forward. The End of Poverty. The Strategic Framework of Poverty Eradication [online]. Available from: http://live58.org/pdf/read_the_strategy.pdf [Accessed 4 May 2018].

Fileta, J., 2014. Live Just.ly. Portland, OR: Micah Challenge USA.

Finlayson, G.B.A.M., 1981. The Seventh Earl of Shaftesbury, 1801-1885. Vancouver: Regent College Publishing.

Fowler, A., 1999. Advocacy and Third Sector Organizations: A Composite Perspective. International Perspectives on Voluntary Action: Reshaping the Third Sector, London: Earthscan, 18, 242-257.

Freeman, D., ed., 2012. Pentecostalism and Development. Churches, NGOs and Social Change in Africa. Basingstoke: Palgrave Macmillan.

Freeman, D., 2018. From 'Christians Doing Development' to 'Doing Christian Development': The Changing Role of Religion in the International Work of Tearfund. Development in Practice, 28 (2), 280-291.

Freeman, D., 2019. Tearfund and the Quest for Faith-Based Development. London: Routledge.

Freston, P., 2001. Evangelicals and Politics in Africa, Asia, and Latin America. 1st ed. Cambridge: Cambridge University Press.

Friesen, E., 2012. Challenging Global Finance. Civil Society and Transnational Networks. Basingstoke: Palgrave Macmillan.

Gasaway, B.W., 2014. Progressive Evangelicals and the Pursuit of Social Justice. 1st ed. Chapel Hill, NC: University of North Carolina Press.

Gordon, G. 2002. Advocacy Toolkit. Teddington: Tearfund.

Green, P., and Hewitt, B., 2011. 21st Century Evangelicals: A Snapshot of the Beliefs and Habits of Evangelical Christians in the UK. London: Evangelical Alliance. 
Haynes, J., 2014. Faith-Based Organizations at the United Nations. New York, NY: Palgrave Macmillan.

Heasman, K., 1962. Evangelicals in Action: An Appraisal of their Social Work in the Victorian Era. London: G. Bles.

Hudson, A., 2002. Advocacy by UK-Based Development NGOs. Nonprofit and Voluntary Sector Quarterly, 31 (3), 402-418.

Hutchinson, M., and Wolffe, J., 2012. A Short History of Global Evangelicalism. 1st ed. Cambridge: Cambridge University Press.

Jones, B., and Petersen, M.J., 2011. Instrumental, Narrow, Normative? Reviewing Recent Work on Religion and Development. Third World Quarterly, 32 (7), 1291-1306.

Koehrsen, J., and Heuser, A., 2019. Beyond Established Boundaries: FBOs as Developmental Entrepreneurs. In: J. Koehrsen and A. Heuser, eds. Faith Based Organisations in Development Discourses and Practice. London: Routledge.

Ladd, G.E., 1959. The Gospel of the Kingdom: Scriptural Studies in the Kingdom of God. Grand Rapids, MI: Eerdmans.

Martin, D., 2002. Pentecostalism: The World their Parish. 1st ed. Oxford: Blackwell Oxford.

McLachlin, V., and Edwards, J., 2012. The Jesus Agenda: Study Guide [online]. Available from: www.christianaid.org.uk/Images/the-jesus-agenda-study-guide.pdf [Accessed 25 July 2017].

Micah Challenge Australia, 2011. Bible Study: Introducing Advocacy [online]. Available from: http://d3n8a8pro7vhmx.cloudfront.net/micahaustralia/legacy_url/189/BibleS tudy_edited_FINAL.pdf?1444111417 [Accessed 25 July 2017].

Micah Challenge International, 2012. Use by 2015: A Scrapbook of Great Ideas for Halving Poverty. London: Micah Challenge.

Micah Network, 2001. Micah Declaration on Integral Mission [online]. Available from: www.micahnetwork.org/sites/default/files/doc/page/mn_integral_mission_declaration_ en.pdf [Accessed 25 July 2017].

Moberg, D.O., 1972. The Great Reversal: Evangelism versus Social Concern. 1st ed. Philadelphia, PA: Lippincott.

Padilla, R., 2002. Integral Mission and Its Historical Development. In: T. Chester, ed. Justice, Mercy \& Humility: Integral Mission and the Poor. Carlisle: Paternoster Press, $42-58$.

Pally, M., 2011. The New Evangelicals: Expanding the Vision of the Common Good. Grand Rapids, MI: Edermans.

Pettifor, A., 2006. The Jubilee 2000 Campaign: A Brief Overview. In: C. Jochnick and F.A. Preston, eds. Sovereign Debt at the Crossroads: Challenges and Proposals for Resolving the Third World Debt Crisis. New York, NY: Oxford University Press, 297-318.

Raistrick, T., 2010. The Local Church: Transforming Community. In: B.E. Woolnough and W. Ma, eds. Regnum Edinburgh 2010 Series. Holistic Mission: God's Plan for God's People. Oxford: Regnum Books, 137-159.

Ranger, T.O., ed., 2008. Evangelical Christianity and Democracy in the Global South, Evangelical Christianity and Democracy in Africa. Oxford: Oxford University Press.

Reitan, R., 2007. Global Activism. London: Routledge.

Reynolds, A., and Offut, S., 2014. Global Poverty and Evangelical Action. In: B. Steensland and P. Goff, eds. The New Evangelical Social Engagement. New York, NY: Oxford University Press, 242-263.

Rugendyke, B., ed., 2007. NGOs as Advocates for Development in a Globalising World. London: Routledge. 
Sider, R., 1977. Rich Christians in an Age of Hunger: A Biblical Study. Westmont, IL: Intervarsity Press.

Sloane, A., 2011. Justifying Advocacy: A Biblical and Theological Rationale for Speaking the Truth to Power on Behalf of the Vulnerable. The John Saunders Lecture [online]. Available from: http://d3n8a8pro7vhmx.cloudfront.net/micahaustralia/legacy_url/190/ Sloane_Andrew - Justifying_advocacy_(John_Saunders_Lecture_19_Oct_2011). pdf? 1444111418.

Steensland, B., and Goff, P., eds., 2014. The New Evangelical Social Engagement. New York, NY: Oxford University Press.

Swartz, D.R., 2012a. Embodying the Global Soul: Internationalism and the American Evangelical Left. Religions, 3 (4), 887-901.

Swartz, D.R., 2012b. Moral Minority: The Evangelical Left in an Age of Conservatism. Philadelphia, PA: University of Pennsylvania Press.

Tearfund, 1996. Mission, Beliefs, Values. Teddington: Tearfund.

Tearfund, 2015. Annual Report and Financial Statements 2014/15 [online]. Available from: www.tearfund.org/ /media/files/main_site/about_us/financial_reports_2015.pdf [Accessed 17 May 2018].

Ter Haar, G., and Ellis, S., 2006. The Role of Religion in Development: Towards a New Relationship Between the European Union and Africa: The Winner of the EJDR Prize 2006. The European Journal of Development Research, 18 (3), 351-367.

Thacker, J., 2015. From Charity to Justice: Revisited. Transformation: International Journal of Holistic Mission Studies, 32 (2), 112-127.

Tinker, M., 1999. Reversal or Betrayal? Evangelicals and Socio-Political Involvement in the Twentieth Century. Churchman, 33 (3). Available from: http://archive.churchsociety. org/churchman/documents/CMan_113_3_Tinker.pdf [Accessed 30 April 2018].

Tizon, A., 2011. Precursors and Tensions in Holistic Mission: An Historical Overview. In: B. Woolnough and W. Ma, eds. Holistic Mission: God's Plan for God's People. Oxford: Wipf and Stock Publishers, 61-75.

Tomalin, E., ed., 2015. The Routledge Handbook of Religions and Global Development. London: Routledge.

Tresser, J.R., 2009. Micah's Challenge: The Church's Responsibility to the Global Poor Edited by Marjike Hoek and Justin Thacker. Religious Studies Review, 35 (3), 173.

Winter, E., and Woodhead, L., 2014. Micah Challenge: An Evangelical Experiment in Development Advocacy: Evaluation Report [online]. Available from: www.micah challenge.org/upload/resources/media_items/MC_report_030414.pdf [Accessed 17 May 2018].

World Evangelical Fellowship, 1983. Transformation: The Church in Response to Human Need. Statement of the Wheaton Consultation [online]. Available from: www.laus anne.org/content/statement/transformation-the-church-in-response-to-human-need [Accessed 17 May 2018].

Yanacopulos, H., 2015. International NGO Engagement, Advocacy, Activism: The Faces and Spaces of Change. London: Palgrave Macmillan.

Young, M.P., 2006. Bearing Witness against Sin: The Evangelical Birth of the American Social Movement. Chicago, IL: University of Chicago Press. 


\title{
4 World Vision and 'Christian values' at the United Nations
}

\author{
Jeffrey Haynes
}

World Vision is a 'Christian relief, development and advocacy organisation dedicated to working with children, families and communities to overcome poverty and injustice' (World Vision International 2016c). Founded in the US soon after the end of World War II, World Vision is today one of the largest developmentfocused faith-based organisations (FBOs), with an annual income of \$826.9 million in 2013, rising to $\$ 1,002$ billion in 2015 (Heist and Cnaan 2016, p. 8). World Vision not only receives very substantial sums each year from individuals but also gets significant funds from the British, Canadian, German, US and other governments. World Vision also receives substantial amounts of money from the European Union and major state-funded development agencies such as AusAid and USAid. In addition, World Vision has a significant presence at the United Nations (UN). The UN is a key focus and environment of World Vision's advocacy, where it works closely with a network of governments, UN agencies, FBOs and international non-governmental organisations (INGOs) to pursue child-focused development campaigns.

In sum, World Vision has evolved over time into a globally focused, development FBO working to improve outcomes especially for children, particularly in the Global South. World Vision began its work explicitly as a Christianorientated, child-protection entity, openly drawing on 'Christian values' to pursue and justify its work. Today, World Vision works with an array of state and nonstate actors in various contexts, including at the UN. The key issue examined in this chapter is: to what extent does World Vision wear its Christian values 'on its sleeve' when undertaking development work at the UN with an array of state and non-state, faith-based and secular, actors, working to overcome development shortfalls affecting children in the Global South?

The wider aim of the chapter is to examine World Vision in the context of FBOs and their attempts to seek to influence debate and decision-making at the UN. Seeking to shape international development work, World Vision becomes a development entrepreneur (Koehrsen and Heuser 2019 in this volume). Increasing attention on FBOs in this context has followed what is widely understood as a widespread, post - Cold War 'religious resurgence', which characterises a novel 'postsecular' international environment. One aspect of the new postsecular environment is increasing focus on global public policy at the UN, from FBOs 
from various religious traditions. The UN is particularly important in this regard because: (1) it is the largest intergovernmental organisation, with 193 member states; (2) it is the most important global public policy focus; and (3) hundreds of FBOs have an institutionalised presence at the UN, via official status with the Economic and Social Council (ECOSOC). Overall, the UN regularly engages with more than 3,000 non-governmental organisations afforded 'official' UN status. Around $10 \%$ are classified as FBOs, implying that their activities and goals are significantly moulded by religious orientations and principles. This does not necessarily imply, however, that FBOs at the UN are 'religiously pure', that is, unwilling to work with non-religious entities, including both states and non-state actors. In fact, many FBOs, including World Vision, are willing to interact at the UN with both state and non-state entities which share ideological although not necessarily religious proclivities. Interacting with actors from divergent discursive fields and flexibly adapting to their logics, World Vision constitutes a boundary organisation (Koehrsen and Heuser 2019 in this volume).

The chapter is structured as follows. The first section examines World Vision's development from its origins as a Christian-focused child protection entity to become one of the world's largest international FBOs. The second section focuses on World Vision's activities at the UN, explaining how it seeks to pursue its objective of global advocacy for children's development. In this section, I examine World Vision's central involvement in two important projects: (1) the Global Strategy for Women's and Children's Health, and (2) the Global Partnership to End Violence Against Children. The third section investigates how World Vision pursues its goals at the UN, via what are known as 'side events', which involve interaction between both state and non-state actors in order to publicise and pursue specific issues.

\section{Motivations and approach of World Vision's development work}

This section examines World Vision's development from its origins as a Christianfocused child protection entity to become one of the world's largest international FBOs. Today, World Vison regularly works in partnership with both state and nonstate actors, including UN agencies and FBOs and INGOs, in pursuit of childorientated, development-focused goals throughout the Global South.

World Vision's origins date from 1947. In that year, an American Baptist minister on a trip to China, Robert Pierce (1914-1978), met a teacher, Tena Hoelkedoer. At the time, China was enduring the aftermath of Japanese military occupation and civil war. Ms. Hoelkedoer introduced to Reverend Pierce a deprived, helpless and abandoned young child named White Jade. While Ms. Hoelkedoer was unable to care for the child herself, she was concerned about White Jade's future. Ms. Hoelkedoer asked Reverend Pierce if he could help the child financially. In response, Robert Pierce gave Ms. Hoelkedoer US $\$ 5^{1}$ for the child, and also committed himself to sending the same sum each month for the child's benefit. Returning to the US, Pierce was motivated to found an organisation dedicated to disadvantaged 
children's wellbeing, and World Vision was created in 1950. World Vision's first child sponsorship programme began in 1953, in direct 'response to the needs of hundreds of thousands of orphans at the end of the Korean War'. World Vision's work expanded over the next two decades, and by the mid-1970s the organisation was working in Asia, Latin America, Africa, the Middle East and Eastern Europe. By the 1980s, World Vision 'embraced a broader community development model and established an emergency relief division'. Later, its burgeoning activities expanded further, focusing on addressing 'the causes of poverty by focusing on community needs such as water, sanitation, education, health, leadership training and income generation'. As a consequence, over time, World Vision 'became more active in working with governments, businesses and other organisations in addressing issues such as child labour, children in armed conflict and the sexual exploitation of women and children' (World Vision International 2016b).

World Vision's concerns about how to bring together both Christian and 'secular' approaches to development is reflected in recent scholarly coverage of potential faith bias of development-focused FBOs, such as World Vision and Islamic Relief (Ware et al. 2016). The issue is controversial because explicitly expressed faith orientation of a development-orientated FBO may significantly affect not only how and with whom such an organisation works but also who will benefit from its development work. On the other hand, recent studies have found that several faith-based development entities, such as World Vision, Oxfam and Save the Children, although 'founded by religious leaders' became 'more secular over time' (Ware et al. 2016, p. 330).

We can see this in relation to several of the FBOs/INGOs that World Vision works closely with at the UN. We have already noted that World Vision is a child-focused, development organisation, founded in 1950, with a Christian ethos and a rights-based approach to its humanitarian and development work. FBOs/ INGOs that World Vision works closely with at the UN include others which have their roots and values in Christian beliefs. For example, Save the Children, founded in 1919, is today secular in orientation but when founded was overtly Christian in ethos and focus (Save the Children 2016). ChildFund International, established in 1938, is much like World Vision: a 'global network of childcentered development organizations working in the poorest countries around the world to create opportunities for disadvantaged children'. Like World Vision, ChildFund International's mission is to create long-term, sustainable, communitybased solutions to development problems affecting children and their families. Also like World Vision, ChildFund International shifted over time from an overtly Christian-focused outlook to one informed by a rights-based approach to its work. In fact, this affected the organisation quite significantly. Ministry Watch, which describes itself as an 'independent evangelical Christian' organisation, monitors and rates FBOs for the 'seriousness of their Christian commitment' and issues 'donor alerts' if they suspect an FBO lacks 'real commitment' (Hopgood and Vinjamuri 2012, p. 46). ${ }^{2}$ In 2004, MinistryWatch.com issued an 'alert' about the 'Christian Children's Fund' (CCF), as it then was, claiming it was not 'Christian enough'. Although it is not clear that it was related to the MinistryWatch.com 
charge, a few years later, in 2009, CCF dropped the 'Christian' nomenclature and became ChildFund International, 'simultaneously opening itself up to new, nonfaith-based funding while cutting itself off from the marketing advantages of wider religious branding' (Hopgood and Vinjamuri 2012).

World Vision also works closely at the UN with avowedly secular childfocused development agencies, for example Plan International. ${ }^{3}$ Plan International was founded in 1937 as a secular child-protection agency 'with a mission to promote and protect the rights of children'. Its founders were a British journalist, John Langdon-Davies, and a refugee worker, Eric Muggeridge. Their original aim was 'to provide food, accommodation and education to children whose lives had been disrupted by the Spanish Civil War' (Plan International 2016). Finally, SOS Children's Villages was founded by Hermann Gmeiner in 1949 in Imst, Austria, to give 'long-term care to children who had lost their homes or families in the Second World War'. Unlike World Vision and ChildFund International, SOS Children's Villages was and is 'non-denominational', an apolitical charity which 'respects the religions and cultures of the local community' (SOS Children's Villages).

The scholarly literature on FBOs was recently comprehensively surveyed by Heist and Cnaan (2016) and Ware et al. (2016). Heist and Cnaan (2016) report that some scholars believe that there is a generic 'faith-based' sector involved in international development, distinct and separate from a 'secular' sector. Ware et al.'s comprehensive survey of how 'faith' is perceived to shape development-focused FBOs, such as World Vision, shows however that 'faith' is actually a rather flexible notion, employed to a lesser or greater extent depending on the context one is referring to, including the UN. Hopgood and Vinjamuri (2012, p. 45) contend that '[b]y controlling resources, defining access requirements and monitoring ongoing operations, the United Nations . . . exert[s] a dramatic effect on the organizational structures and branding choices' that FBOs, such as World Vision, make. Many FBOs, including World Vision, are somewhat dependent on public donors, such as governments and aid agencies. As Table 4.1 shows, in 2015 World Vision received just over half of its income (56.9\%) from 'private cash donations', \$255 million from 'gifts-in-kind', \$172 million (17.2\%) from 'public grants' and \$4 million from 'other income'. This indicates that while more than $80 \%$ of World Vision's

Table 4.1 World Vision operating revenue, 2013-2015

\begin{tabular}{lrrr}
\hline Operating Revenue (in \$ millions) & 2013 & 2014 & 2015 \\
\hline Private cash contributions & 599 & 600 & 571 \\
Public grants (food and cash) & 179 & 195 & 172 \\
Gifts-in-kind & 196 & 232 & 255 \\
Other income, net & 7 & 8 & 4 \\
Total operating revenue & $\mathbf{9 8 1}$ & $\mathbf{1 , 0 3 5}$ & $\mathbf{1 , 0 0 2}$ \\
\hline
\end{tabular}

Source: World Vision 2013-2015. 
income comes from non-governmental sources, the amount received annually from public sources is significant for its overall income.

Indeed, as Hopgood and Vinjamuri note, 'the size of their global operations would be unsustainable without this [public] funding'. In the US, for example, World Vision receives 'substantial sums of USAID money' (Hopgood and Vinjamuri 2012). What this implies is that while drawing on both public funds and private donations is strategically and financially wise, it also suggests that to continue to receive funding from both sources it is essential to be 'secular' enough to receive funding from public bodies, such as USAID, while also being sufficiently 'Christian' to continue to receive donations from individual Christians who support World Vision with hundreds of millions of dollars a year annually because of its Christian values. Barnett (2012, p. 207) reports that 'one long-time staff member' of World Vision put it in the following way: World Vision 'is "constantly taking its temperature", by which he meant the [World Vision] staff were always wondering about the relationship between their religious values and their mandates'.

In the early 2000s, World Vision addressed this issue head on, undertaking a wide-ranging review to ascertain what, if anything, is 'Christian' about development. Justin Byworth - at the time Coordinator of Development Programming, Development Resources Team, World Vision - argued that World Vision's development work should be consistently characterised by 'transformational development' (Byworth 2003). The notion of 'transformational development' brings together both 'objective' developmental 'best practice' and World Vision's foundational Christian values and beliefs. In other words, 'transformational development' is conceived of by World Vision 'in terms of both developmental "best practice" and the Christian values and beliefs taken to frame the work of the organisation' (Wet 2011, p. 10; also see Wet 2013). For a useful general discussion of 'transformational development', see (Meyers 2011 and cf. Freeman in this volume).

The evidence in this chapter bears out (Whaites 1999) assessment that World Vision's transformation at the UN - from tiny, humanitarian assistance entity 70 years ago to large, global development agency today - was characterised by pragmatic development of a 'fusion of mainstream Christianity and the pursuit of the concept of partnership', with various secular and faith-based, state and nonstate, entities. Hopgood and Vinjamuri (2012, p. 37), contend that World Vision 'has thrived because of, not despite, its religious credentials. Its field operations are in line with secular humanitarian norms, but it raises much of its cash and motivates its work and staff on a religious basis' (emphasis added).

How does World Vision manage to square their faith principles with the secular principles of the UN and work sustainably in partnerships and networks featuring UN agencies, governments and civil society actors, many of which are secular? (Mueller 2016). Many FBOs are interested in development in the Global South, as it is an issue intimately tied to many theological interpretations of the world and how to improve it. It may well be that such faith characteristics are conducive to intra-faith responses to humanitarian crisis and more generally to 
development issues. Kevin Jenkins, World Vision President and Chief Executive Officer (CEO), points to,

Common threads that run through all major belief systems. . . [and] draw us together. Important foundations like the 'Golden Rule of reciprocity and respect' offer a practical basis for how to engage with others: (1) to do good to the widow and orphan, (2) to welcome the homeless stranger, and (3) to treat the sick, and feed the hungry.

(Jenkins 25 September 2015)

Peter Howard, a senior employee of a Christian FBO, Emergency Response, argues that six characteristics strengthen what he calls 'faith-driven humanitarianism': (1) sacredness of life, 'Faith inherently understands the sacredness, dignity and transcendence of each person'; (2) presence, 'Faith brings to bear one of the strongest and most sustainable local and global networks'; (3) conscience: 'Faith communities are advocates for the poor and most vulnerable in humanitarian response'; (4) hope, 'Faith has a redemptive narrative of hope in the midst of suffering'; (5) mercy, 'Faith brings a theology of Forgiveness and Mercy which can stop cycles of violence'; and (6) charity, 'Faith brings values based sustainable giving vs tax based (or forced giving)'. At the same time, Howard acknowledges that many donor governments as well as UN agencies - and more generally what he calls 'the secular international community' - distrust or are suspicious of 'people of faith in the humanitarian community' (Howard 2015, p. 2). Howard argues that to counter 'the international community's fear of proselytism and the challenge of our own constituencies who may engage in humanitarian work for the purpose of conversion', faith actors must 'speak the language of the international community' (Howard 2015, p. 3). In this respect, (Howard 2015, p. 3) points to the Code of Conduct for the International Red Cross and Red Crescent Movement and NGOs in Disaster Relief, as an example of such language, a code which World Vision explicitly adheres to in its humanitarian and development work in the Global South. The Code specifies that aid must be 'given regardless of the race, creed or nationality of the recipients and without adverse distinction of any kind. Aid priorities are calculated on the basis of need alone'. This obviously implies that aid will not be used to further a particular political or religious standpoint. However, Benthall (2012, p. 67) contends that 'whereas some Christian NGOs such as Christian Aid and CAFOD (the British arm of Caritas Internationalis) explicitly avoid any proselytism, there is some ambiguity in the case of the more Evangelically inspired Christian NGOS such as Tearfund and World Vision'. However, despite Benthall's claim, both Tearfund and World Vision are members of the Disasters Emergency Committee in London which means that they necessarily adhere to the Red Cross/Red Crescent Code of Conduct. A key principle of this Code is non-discrimination and provision of services on the sole basis of need. At the same time, it may well be that in the field some World Vision employees, who are very often committed Christians, may take the opportunity to talk up the virtues of Christianity in the course of their work. ${ }^{4}$ 
On the other hand, evidence indicates that in its work at community level, World Vision does not discriminate in favour of Christians to the detriment of those of other faiths. For example, World Vision works in many environments where Christians are in a decided minority, including Palestine, Niger and South Sudan. For example, World Vision is active among Palestinians in the Gaza Strip, where only about $6 \%$ of Palestinians are Christian and the great majority - around 93\% - are Sunni Muslims. However, World Vision's presence and work in Palestine is controversial. This is not because it disproportionately aids minority Christian Palestinians to the detriment of the Muslim majority. Rather, World Vision's presence is controversial because, it is claimed by conservative, right-wing evangelical Christians from the US and elsewhere, that it is anti-Israel. In addition, World Vision is heavily involved in current efforts to rebuild Syria after the civil war, a country with a tiny and declining Christian community (BBC News 2015).

However, this does not imply that World Vision condones employees' unofficial, grassroots-level Christian proselytisation. Officially, World Vision adopts rightsbased, not theologically orientated, language in the context of its work in international development, including at the UN. Recently, World Vision outlined its 'human rights-based approach to the implementation of policies and programmes to reduce and eliminate preventable mortality and morbidity of children under 5 years of age' (World Vision International 2016c, p. 1; see also: UNICEF 2012). Working closely with the UN Office of the High Commissioner for Human Rights, the World Health Organisation, as well as various governments, non-state actors and civil society, World Vision explicitly expressed its strategies and goals in the language of rights, not theology, to provide 'input and consultation on best practices and programming in reducing and eliminating mortality and morbidity of children under 5 years of age' (UNICEF 2012).

In a recent 'Background Paper', written for the World Vision Institute of Friedrichsdorf, Germany, Laura Schelenz points to the desirability of including all members of a community - not only those who adhere to a certain religious faith in order to reduce 'discontent and frustration' and lead 'to more harmonious and healthy community life. A rights-based approach to development as supported by World Vision and many other NGOs is therefore important for the development of communities, countries, and regions' (Schelenz 2016, p. 11). Typically, in the context of the MDGs and SDGs, UN initiatives bring together both faith-based and secular actors in pursuit of shared goals, related to improved wellbeing for women and children in the Global South. What motivates the partners in such development initiatives is shared commitment to improving health of children and women in the Global South, while reducing men's violence against them. Perhaps the only language which is possible to combine activities of both faith-based and secular actors in this endeavour is rights-based. According to Schelenz (2016, p. 6), World Vision draws its inspiration from the UN Convention on the Rights of the Child, promulgated in 1989. Overall, World Vision explicitly acknowledges both the necessity and value of a human rights - based approach 'to reducing preventable child illness and deaths. World Vision claims to be "fully committed to addressing determinants of child health and nutrition by focusing on health programming, 
advocacy, accountability and by empowering children's participation in decisionmaking' (World Vision 2016, p. 2). Finally, World Vision claims that '[c]onsistent with our policies, programmes and principles as a Christian organisation, we will continue to invest more smartly, to foster and share information and knowledge, and to grow partnerships with anyone who believes in ensuring the most vulnerable stay healthy' (World Vision International 2016a).

In sum, while World Vision undoubtedly began as an explicitly Christianfocused agency seven decades ago, over time it has significantly widened the focus of its work, both in scope and territorially, including at the UN; today, World Vision seeks to assist children - as well as women and adolescents - of any faith or none. World Vision appears to work via a rights-based approach to advocate for the interests of children and women in the Global South. The faith of recipients of its assistance does not appear to be an important issue when assisting those in need.

In the next section, we assess the development work of World Vision at the UN and see how it manages to work with an array of faith-based and secular partners in pursuit of development goals. Given its foundational Christian philosophy and values, how does World Vision manage to work with such a range of such actors, some of which do not identify with World Vision's Christian values, including UN agencies and a Muslim FBO, Islamic Relief, which in recent years has become an important partner with World Vision in several parts of the world? In short, how does World Vision resolve the issue of working with non-Christian entities at the UN? Whaites (1999) suggests that, first, World Vision is primarily results orientated, necessarily pragmatic and practically orientated when seeking to achieve its development-focused goals. Second, he avers that World Vision is aware that when working in partnerships with various state and non-state actors at the UN, that it is not realistic or sensible or good policy to seek to adhere openly or rigidly to Christian-focused and Christian-informed goals. This is because the UN is a very secular entity, where faith is customarily treated with suspicion or hostility (Haynes 2014).

\section{World Vision at the UN: global advocacy for children's development}

The development of secularism at the UN followed a long process of secularisation which was once almost universally understood to be 'irreversible, equated with modernization and progress. Religious institutions seemed to have lost much of their influence. Religion had little or no visible role in international relations', including in relation to development (ACT Alliance 2015, p. 1). While this might accurately describe the position at the UN in the first decades of its existence, in recent years both UN agencies and governments, in seeking to address pressing issues such as 'poverty, development, crisis, and conflict' increasingly rely on 'non-governmental', including faith-based, 'humanitarian relief and development organizations as partners and primary actors in meeting humanitarian needs worldwide' (ACT Alliance 2015, p. 2). 
Recent years have seen significant involvement of various FBOs - including, World Vision, Religions for Peace, Caritas Internationalis and Islamic Relief - in international humanitarian and development work, including in the context of the MDGs and SDGs (Haynes 2007, 2013; Barnett and Stein 2012). FBOs at the UN work on specific issues, including: reducing infant and maternal mortality, providing universal primary education, reducing adult illiteracy and arresting the spread of HIV/AIDS (Haynes 2014). The UN is a favoured environment to pursue these concerns because of its role as a focal point of global public policy and its unique environment, one where governments, UN agencies, NGOs and FBOs can get together, consult and work with each other both informally and formally. ${ }^{5}$ In this section, we examine and account for World Vision's strategy and activities at the UN. Second, we survey World Vision's partnerships with both FBOs and INGOs to highlight common ground when it comes to pursuing shared objectives, including child-protection and the advancement of children's rights.

The UN's focus on international development was given both emphasis and momentum by the Millennium Development Goals (MDGs), which ran from 2000 to 2015. During that time, the UN became a key focus of the international community's efforts to improve development outcomes in impoverished countries in the Global South, especially for the most vulnerable people - including, women and children. Like many other NGOs and FBOs, during the MDGs, World Vision focused much attention on its eight core goals of the MDGs. ${ }^{6}$ When the MDGs came to an end in 2015, the UN adopted new, ambitious and wide-ranging objectives - the Sustainable Development Goals (SDGs) - to be achieved during 2015-2030. ${ }^{7}$ The SDGs build on the MDGs - yet they are notably more comprehensive and wide-ranging, with a global focus and emphasis on environmentally sustainable development, centred on building partnerships between governments, UN agencies and civil society, including FBOs and NGOs as well as business actors (2015). World Vision 'believes that sustainable development starts and ends with healthy, nourished and well-educated children free from all forms of violence - and the SDGs represent an unprecedented opportunity to get us there within a generation' (World Vision 2016, p. 1).

In the 2000s, the MDGs and SDGs followed economically liberal structural adjustment programmes (SAPs). SAPs were ubiquitous in the Global South in the 1980s and 1990s, championed by several UN agencies, including the World Bank and International Monetary Fund (IMF). Yet, despite huge ideological and financial commitment from both the World Bank and the IMF, SAPs were a widespread and egregious failure, which led to strong critiques from secular development INGOs and FBOs, including World Vision (Haynes 2007). The WCC, an ecumenical body of Protestant and Orthodox churches, accused the World Bank and the IMF of promoting and supporting an ideologically driven and narrowly economistic conception of development via SAPs, which crucially lacked a holistic focus on human and spiritual development (Joshi et al. 2013). Some FBOs, and single bodies of churches, including the WCC and World Vision, wanted to see a shift away from state and market-led approaches to a broader, more holistic, conception of human and spiritual development, to build improved outcomes through 
close working with a variety of partners, not only governments. The FBOs wanted to see more involvement from civil society and, more generally, increased grassroots participation with the goal to qualitatively enhance the lives of the poorest and most vulnerable, especially women and children. To pursue this radically different vision of development, some development-orientated FBOs, including World Vision, became 'legitimate actors in the field of development and humanitarian aid' (Jones and Petersen 2011, p. 2). In pursuit of this goal, the World Bank had a change of emphasis. The World Bank's authoritative study, Voices of the Poor (World Bank 2000), highlighted the importance of enhanced engagement of FBOs in development. The World Bank's approach in this regard was built upon the understanding that many people in the countries of the Global South have more trust and confidence in their religious leaders than in secular leaders, including elected politicians.

To sum up this section so far: development of the MDGs from the late 1990s/ early 2000s, followed by the SDGs from 2015, together highlighted a new global public policy focus on civil society involvement in development, including that of FBOs. This followed widespread failure of SAPs in the Global South in the 1980s and 1990s. The aim henceforward was to develop government and non-state partnerships to devise ways to try to achieve better international development outcomes. We shall see in the next section of the chapter how World Vision engages with a changed development focus via its advocacy work for deprived children at the UN in partnership with other agencies.

World Vision has a significant and active presence at the UN, working closely with UN agencies, including the United Nations Population Fund (UNFPA), the UN Children's Fund (UNICEF), UN Women and the World Health Organisation. It also works closely with a network of NGOs, including Save the Children, Child Fund Alliance, Pan International and SOS Children's Villages, and FBOs, including a Muslim FBO, Islamic Relief. In early 2016, Arelys Bellorini, World Vision Senior Advisor on Advocacy and Partnerships, commented that,

Here in New York, we have a very strong partnership with other child-focused organisations. ... We work with Save the Children, we work with ChildFund Alliance [sic], Plan International, SOS Children's Villages. We work with them because they have an office [in New York]. So, if there were other childfocused organisations who have offices, we would also work with them. But they have a representation here. So these groups were working together on the post-2015 [SDGs]. And every time there are major children's issues that we want to raise, we come together. ${ }^{8}$

World Vision's significant current involvement in development issues at the UN is framed and contextualised by the MDGs and SDGs (Boehle 2010). This is manifested, first, in growing involvement in UN-related development programmes and, second, in participation in international networks of state and various nonstate actors, both faith-based and secular, in pursuit of development goals, especially those related to the improved well being of women and children. Third, 
the growth in concern with child-focused development outcomes was captured in the SDGs, which sought to expand and extend goals of international development outcomes as key components of international activities to reduce conflict and improve outcomes related to peace, co-operation and prosperity, especially in the Global South. In summary, World Vision's current activities at the UN focus on 6 of the 17 SDGs, as noted in Table 4.2.

World Vision employs four main strategies at international fora, including the UN: 'Partnerships, alliances and coalitions', 'Lobbying and direct engagement with decision makers', 'Media and communications for public influence' and 'Children's and youth participation'. Next, we examine World Vision's strategies in these respects by focusing on two current UN-coordinated campaigns: Global Strategy for Women's and Children's Health and The Global Partnership to End Violence against Children. The overall aim is to identify the tactics and approaches World Vision utilises in order to pursue its activities at the UN, as it engages with governments, UN agencies and INGOs/FBOs in the context of the SDG-related goals. World Vision works from the premise that it is important to ensure that the voices of children are regularly and prominently heard in debates about development and the best ways to achieve improved outcomes for children, as shown in Table 4.3.

\section{The Global Strategy for Women's and Children's Health}

The UN Secretary-General, Ban Ki-moon, established a major new initiative, Global Strategy for Women's and Children's Health, in September 2010 during the United Nations Millennium Development Goals Summit. Following the transition to SDGs in 2015-2016, the initiative was relaunched in order to pursue objectives with renewed vigour and commitment, as well as new commitments, new partnerships, new money and new impetus.

The Global Strategy for Women's and Children's Health brings together governments, UN agencies and INGOs/FBOs to pursue improved development outcomes for women and children in the Global South. World Vision and several other INGOs/FBOs are centrally involved in the Global Strategy. In addition, several UN agencies have leading roles in the network: the UN Children's Fund (UNICEF), UN Population Fund (UNFPA), UN Development Programme (UNDP) and UN Women. By 2016, the Global Strategy had attracted over ' $\$ 25$ billion in initial commitments from over 120 organisations and over 40 governments'. It sought to achieve two main outcomes: (1) to create 'a roadmap to end all preventable deaths for women, children and adolescents, and [to] ensure that they not only survive, but also thrive and transform the world', and (2) to 'present an accountability framework and mechanism that will align and help track progress of the related Sustainable Development Goals, highlight the benefits of innovation while stressing that countries are in the driver's seat and young people, at the heart of the Sustainable Development Goals' (Every Woman Every Child 20 January 2016, pp. 1-2). 
Table 4.2 Sustainable Development Goals: improved outcomes for children

\section{Sustainable Development Specific area to be improved}

Goal

'Good health and well-being': ensure healthy lives and
promote well-being for all
promote well-being for all

Good health and wellbeing (SDG 3)

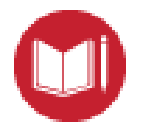

Quality education (SDG 4)

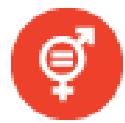

4.7 - By 2030, ensure that all learners acquire the knowledge and skills needed to promote sustainable development, including, among others, through education for sustainable development and sustainable lifestyles, human rights, gender equality, promotion of a culture of peace and nonviolence, global citizenship and appreciation of cultural diversity and of culture's contribution to sustainable development

4.a - Build and upgrade education facilities that are child, disability and gender sensitive and provide safe, non-violent, inclusive and effective learning environments for all

5.2 - Eliminate all forms of violence against all women and girls in the public and private spheres, including trafficking and sexual and other types of exploitation

5.3 - Eliminate all harmful practices, such as child, early and forced marriage and female genital mutilation

Gender equality (SDG 5)

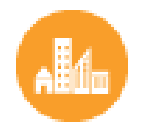

'Make cities inclusive, safe, resilient and sustainable'

Sustainable cities and communities (SDG 11)

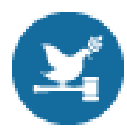

Peace and justice, strong institutions (SDG 16)

16.1 - Significantly reduce all forms of violence and related death rates everywhere

16.2 - End abuse, exploitation, trafficking and all forms of violence against and torture of children

16.3 - Promote the rule of law at the national and international levels and ensure equal access to justice for all 16.9 - By 2030, provide legal identity for all, including birth registration

16.a - Strengthen relevant national institutions, including through international cooperation, for building capacity at all levels, in particular in developing countries, to prevent violence and combat terrorism and crime

17 - Strengthen 'the means of implementation and revitalization of the global partnership for sustainable development'. Emphasises that SDGs 'can only be realized with a strong commitment to global partnership and cooperation.'

Partnerships for the goals (SDG 17) 
Table 4.3 World Vision's advocacy at the UN and at the country level in pursuit of childand women-focused goals

\begin{tabular}{|c|c|c|}
\hline Strategy and tactics & Where focused & Examples \\
\hline $\begin{array}{l}\text { Partnerships, alliances } \\
\text { and coalitions }\end{array}$ & $\begin{array}{l}\text { International fora, } \\
\text { notably the United } \\
\text { Nations }\end{array}$ & $\begin{array}{l}\text { 'Global Strategy for Women's } \\
\text { and Children's Health' and } \\
\text { 'Global Partnership to End } \\
\text { Violence against Children'. }\end{array}$ \\
\hline $\begin{array}{l}\text { Lobbying and direct } \\
\text { engagement with } \\
\text { decision makers }\end{array}$ & $\begin{array}{l}\text { International fora, } \\
\text { notably the United } \\
\text { Nations }\end{array}$ & $\begin{array}{l}\text { 'Global Strategy for Women's } \\
\text { and Children's Health' and } \\
\text { 'Global Partnership to End } \\
\text { Violence against Children'. }\end{array}$ \\
\hline $\begin{array}{l}\text { Community } \\
\text { empowerment and } \\
\text { local-level advocacy }\end{array}$ & Within countries & $\begin{array}{l}\text { 'Citizen Voice and Action' } \\
\text { approach and the 'Citizens' } \\
\text { Hearings' model, related to } \\
\text { women's and children's issues. }\end{array}$ \\
\hline Popular mobilisation & Within countries & $\begin{array}{l}\text { World Vision's annual 'Global } \\
\text { Week of Action', which takes } \\
\text { place in over } 70 \text { countries. } \\
\text { Its purpose is to demonstrate } \\
\text { public commitment to } \\
\text { reducing preventable child } \\
\text { deaths. }\end{array}$ \\
\hline $\begin{array}{l}\text { Media and } \\
\text { communications for } \\
\text { public influence }\end{array}$ & $\begin{array}{l}\text { International fora, } \\
\text { notably the United } \\
\text { Nations }\end{array}$ & $\begin{array}{l}\text { ‘Global Strategy for Women’s } \\
\text { and Children's Health' and } \\
\text { 'Global Partnership to End } \\
\text { Violence against Children'. }\end{array}$ \\
\hline $\begin{array}{l}\text { Children's and youth } \\
\text { participation }\end{array}$ & $\begin{array}{l}\text { International fora, } \\
\text { notably the United } \\
\text { Nations }\end{array}$ & $\begin{array}{l}\text { 'Global Strategy for Women's } \\
\text { and Children's Health' and } \\
\text { 'Global Partnership to End } \\
\text { Violence against Children'. }\end{array}$ \\
\hline
\end{tabular}

Source: World Vision International (2016c).

In 2010, World Vision committed $\$ 1.5$ billion over the next five years to the Global Strategy to support 'a family and community model of health care delivery' (World Vision International 2016a). In 2016, World Vision announced a further major financial pledge to support the Global Strategy: '\$3 billion between 2016 and 2020' - that is, an average of $\$ 600$ million a year - to improve 'sustainable health programming, humanitarian emergency responses, operational research and advocacy at all levels' (World Vision International 2016c). World Vision's 2016 financial investment was especially focused on pursuing its policy of 'community empowerment and local-level advocacy' (World Vision International 2016c, p. 1). In addition to these major financial commitments, World Vision also worked in pursuit of the Global Strategy at the community level in many countries in the Global South. By 2016, World Vision claimed to have 'inspired 20 million people in 70 countries to join us in speaking on behalf of women's and children's health through [their] Child Health Now campaign', which saw many national 
policies and practices improved as a result. In addition, World Vision is in the process of training ' 100,000 community health workers', and strengthening its 'citizen engagement', inter alia, by establishing a 'BabyWASH multi-stakeholder partnership" ${ }^{\prime 9}$ and by mobilising 'around 300,000 faith leaders . . . in 50 countries' (World Vision International 2016a, p. 1).

World Vision's work in pursuit of improved outcomes for women and children in the context of the MDGs was explicitly recognised by the UN SecretaryGeneral, Ban Ki-moon in 2010. Ban praised World Vision 'as a partner of the United Nations' emphasising that

in many countries, World Vision has worked tirelessly to save lives, and bring hope through development assistance and emergency relief. . . . You have made significant contributions towards reducing child mortality, improving maternal health, and combating AIDS, malaria, and other diseases.

(Secretary General 2010)

Later, in January 2016 during the introduction of the SDGs, Ban Ki-moon announced the Global Strategy's 15-member High Level Advisory group, which was tasked by the UN Secretary-General to provide leadership and to help inspire action for women's, children's and adolescents' health during the transition from the MDGs to the universal SDGs agenda. Ban Ki-moon averred that,

Women, children and adolescents are at the heart of the 2030 Agenda. Continued commitment, leadership and action will be critical to achieving our goal of ending all preventable deaths of women, children and adolescents by 2030 and enabling them to reach their full potential.

(Every Woman Every Child 20 January 2016, p. 1)

Chief Executive Officer and President of World Vision, Kevin Jenkins, was named among the High Level Advisory Group's members. Jenkins had previously 'served on the Commission on Information and Accountability for Women's and Children's Health in 2011'. Other members of the High Level Advisory Group included serving and former government ministers, heads of international organisations and business figures. Jenkins was the only member of the High Level Advisory Group from an FBO. In addition to Jenkins, the High Level Advisory Group included the 'Head of the Agency Chair of the H6 (formerly known as $\mathrm{H} 4+$ )', a joint effort comprising several UN agencies (that is, UNFPA, UNAIDS, UNICEF, UN Women, WHO, and the World Bank) to address reproductive, maternal, newborn, child and adolescent health. The H6 serves as the lead technical partners for the Global Strategy for Women's, Children's and Adolescents' Health (Every Woman Every Child 20 January 2016, p. 2).

Initial appointments to the High Level Advisory Group were for a year, during which its members were scheduled to meet twice to report on progress, key challenges and provide recommendations on issues such as financing, accountability and implementation of the Global Strategy. In addition, the High Level Advisory 
Group was to advise the UN Secretary-General in relation to the Global Strategy and link its work to that of other relevant advocacy and advisory groups to encourage collaboration and integration within the relevant areas of the 2030 Agenda for Sustainable Development (see Table 4.2).

In conclusion, a key goal of the Global Strategy for Women's, Children's and Adolescents' Health is to improve wellbeing of these vulnerable groups in the Global South. In 2016, the SDGs provide a focus and opportunity to develop the Global Strategy via a network of state and non-state groups, focused on the UN. In addition to the Global Strategy, the SDGs also helped stimulate a similar campaign and network devoted to reducing violence against children, widely recognised as a key factor in undermining children's health in the Global South. This initiative, the Global Partnership to End Violence Against Children, is another good example of a partnership between various state and non-state actors which use the UN as the focal point of their activities, in order to deal with developmental shortfalls affecting millions of children in the Global South. It indicates that World Vision does not feel the need to wear its Christian values 'on its sleeve' when undertaking development work at the UN with an array of state and nonstate, faith-based and secular actors, working to overcome development shortfalls affecting children in the Global South.

\section{The Global Partnership to End Violence Against Children}

The world's governments set ambitious targets to end violence against children by 2030 as part of the Sustainable Development Goals. The Global Partnership to End Violence Against Children was founded to 'provide a platform for leaders from all sectors who are prepared to stand up for children's rights to live a life free from fear of violence'. Working through the Global Partnership, governments and non-state organisations can pool their resources and expertise to accelerate progress toward the stated goal.

As part of the new sustainable development agenda, governments will make a commitment to ensuring that all people live in peaceful, just and inclusive societies. They will set ambitious targets to be delivered by 2030, in order to deliver the vision of a world where every child grows up free from violence and exploitation. The Global Partnership to End Violence Against Children will help deliver this vision.

(World Vision International 2016d)

Like the Global Strategy for Women's, Children's and Adolescents' Health, the Global Partnership to End Violence Against Children is an initiative that brings together various governments, UN agencies, international organisations, INGOs and FBOs, the private sector and children themselves. The key partners in the initiative from the UN are: UNICEF, WHO, UN Women, UNFPA and the United Nations High Commissioner for Refugees (UNHCR). The INGO/FBO participants are: ChildFund Alliance, Plan International, Save the Children, SOS 
Children's Villages, World Vision and Elevate Children Fund, plus 'various foundations, private sector, leaders of faith, children and young people' (Partnerships for the SDGs 2016).

Referring to the Global Partnership to End Violence Against Children, Cathy Turner, World Vision UK's Child Rights Policy Manager, stated that: 'The scourge of child abuse destroys children's lives in every corner of the world [and] protecting children has long been a core part [of the work of World Vision]'. Turner promised that World Vision would continue to play a leading role in 'the drive to end violence against children. The UK Government has set the right example with a new fund to tackle transnational internet child abuse' (World Vision International $2016 \mathrm{~d}$ and interview with Cathy Turner). ${ }^{10}$

Government ministers from Sweden, Mexico, Indonesia and Tanzania committed their governments to developing explicit and detailed plans to combat violence against children in their countries. The aim was to tackle and deal with behaviours and traditions that further violence, as well as seeking to make schools and state institutions safe for all children, while strengthening and improving data collection about violence and children. The four governments were identified to be among a small group of 'pathfinders'. 'Pathfinders' are governments that seek to be in the vanguard of the design and implementation of novel approaches, such as the Global Partnership, which are developed in the context of the SDGs, and in this case designed to prevent and respond to violence against children. Pathfinder governments aim to be leaders in efforts to respond to and set the lead in dealing with violence against children, in order to try to make their country's children safe. In addition, pathfinder governments also seek to ensure that child victims of violence are no longer marginalised by the global development agenda. To do this, they will 'confront the many factors that leave children vulnerable to violence, assess evidence for what works, and bring together the partners and investment needed to make their societies safer'. Finally, pathfinders are representative of a broad spectrum of countries which would over time aim to take the lead in building 'the political will, plans, and partnerships necessary to play a leadership role as a "champion for children". We are convinced, however, that strong country ownership and a focus on results and evidence will create a virtuous cycle where success breeds further success' (Partnerships for the SDGs 2016).

During the first five years of the initiative (2016-2020), efforts are to be devoted to 'generating sufficient data to establish trends in pathfinder countries, and addressing gaps in the evidence for the violence prevention building blocks' (Partnerships for the SDGs 2016). During 2016, the Global Partnership examined the potential for launching several global initiatives in order to demonstrate the potential for introducing and spreading pioneering approaches to the prevention of violence against children. The aim was to share relevant knowledge via a 'Solutions Summit', to be held in 2017, which would also be the starting point of a regular forum for both state and non-state actors, including UN agencies, FBOs and INGOs, working to end violence against children in the context of the SDGs. In short, the Global Partnership aimed to produce a coordination mechanism and governance structure which would offer an opportunity for both state and non-state 


\section{2}

actors engaged in efforts to end violence against children to come together, link up their efforts and seek as a result to maximise individual impacts via collective actions. The Global Partnership aimed specifically to bring together states and non-state actors in the understanding that various entities working together could make a stronger and more focused collective endeavour with the potential to have more clout and influence than if working separately. While each of these stakeholders could make a valuable individual contribution, and while it is recognised that many entities, both state and non-state, are already working to eliminate violence against children, the Global Partnership works on the premise that such efforts have not in the past been well coordinated and supported, while few if any were universal in scope. In addition, it is envisaged that the Global Partnership's national and global added-value would emanate from its multi-sectoral convening and coordinating role, providing a space at both national and global levels where different actors from different sectors, state and non-state, faith-based and secular, can combine efforts to achieve common goals focused on ending violence against children in the context of the SDGs. The emphasis is on developing, assessing and sharing solutions, to seek to ensure that preventing violence against children becomes a global policy priority during the SDGs period.

In conclusion, the Global Partnership to End Violence Against Children is likely to succeed only if participants, state and non-state, faith-based and secular, are able to work together to rise above current sectoral and disciplinary boundaries which historically have tended to reduce the impact and potency of such endeavours. Participants in the Global Partnership agreed that the SDGs provided an excellent opportunity to pool efforts for greater effectiveness while also concurring that solutions to violence against children can only be delivered at scale if the energies, skills and resources of all parts of society are harnessed. This implies a necessity of reaching out to all those who work for children, either professionally or on a voluntary basis, whether from government, civil society, or the private sector. In addition, it is crucial to build and strengthen networks involving all participants working to end violence against children, to include those working to reduce conflict and strengthen fragile societies and those whose efforts seek to strengthen justice systems and other institutions. Overall, the work of all interested parties, secular and faith-based, state and non-state, needs to be well coordinated and focused to achieve its objectives.

In this section, we have seen the importance of World Vision's engagement with governments, UN agencies and INGOs/FBOs in pursuit of objectives linked to the SDGs. But how does World Vision work at the UN? What strategies and tactics does it employ there in order to pursue campaigns in which it is significantly involved, such as the Global Strategy for Women's, Children's and Adolescents' Health and the Global Partnership to End Violence Against Children? The next section examines what World Vision does at the UN to pursue its objectives in relation to these two campaigns. We will see that, on the one hand, this involves 'partnerships, alliances and coalitions' and 'lobbying and direct engagement with decision makers'. On the other hand, in order to express 'children's and youth participation' and 'media and communications for public influence', it also 
involves World Vision explicitly adopting tactics to achieve maximum impact in these respects.

\section{'Side events' at the United Nations: children's development and the SDGs}

What approaches does World Vision employ at the UN to pursue its goal of improved development outcomes for children in the Global South? ${ }^{11}$ A key role of the World Vision staff in New York, housed in a building a few hundred metres from the UN, is to organise what are known as 'side events', in order to pursue improved development outcomes for children in the context of the MDGs and SDGs. Below, we look briefly at three of these recent events, in order to see how World Vision facilitates 'children's and youth participation' and 'media and communications for public influence'.

The main focal point of World Vision's public and media-related activities at the UN are 'side events'. Side events are 'activities organized outside the formal programme of the session of the Commission, [providing] an excellent opportunity for Member States, UN entities and NGOs to discuss themes of common interest the Commission and other critical gender equality issues' (Side Events 2016). There are two kinds of side events. First, Permanent Missions to the UN and UN entities, such as UN agencies, are permitted to hold side events on UN premises. Second, INGO/FBOs may also organise side events, although they must be held outside United Nations premises, often taking place in the Church Center (located at the intersection of 44th Street and First Avenue, across from the UN Secretariat building). Subject to space availability, any INGO/FBO, including World Vision alone or in partnership with others, may organise and attend these events. Because side events taking place within the UN itself are probably more likely to attract much media attention compared to those which take place outside the UN building, INGOs/FBOs will often seek co-organisers among Permanent Missions and UN entities, so that the event can take place within the UN itself.

The first side event we shall note was entitled: 'Amplifying the voices of children'. World Vision and Plan International co-organised the event to provide a forum for children to call for the inclusion of young people's voices in post-2015 development decisions. It took place during the afternoon of 24 September 2013 at the Instituto Cervantes New York, a building close to UN headquarters. The event took place within the context of a wider initiative at the UN, when 'children from around the world' had gathered in New York to 'demand leaders at the United Nations General Assembly take seriously their views on what should follow the Millennium Development Goals.' The event brought together delegations of children from nine countries from the Global South, who claimed to be representative of children demanding a voice in decision-making, including at the UN. ${ }^{12}$ As World Vision noted, 'Children and young people represent $43 \%$ of the world's population, but their voices are regularly excluded from decisions that affect them' (World Vision International 2013). World Vision's Executive Advisor on Child Rights, Corina Villacorta added that: 'One in every three people in the 


\section{4}

world is under age 18. In many countries, children and young people make up half of the population. And it is children who are more vulnerable and less able to cope with the damaging effects of poverty' (World Vision International 2013).

The World Vision/Plan International side event aimed to build on the momentum of the youth takeover at the UN in July 2013 led by Malala Yousafzai, and subsequent participation of youth delegations at the High-Level Panel on Post2015 events held in the United Kingdom, Liberia and Indonesia. The success of these events led two High-Level Panel members to call on the UN Secretary General to support a Youth High-Level Panel on Post-2015, a proposal that will be discussed at the General Assembly.

The second side event was held on 5 February 2014 and entitled 'A World without Violence against Children'. It took place at UN headquarters in New York and was organised in the context of the eighth session of the inter-governmental Open Working Group on Sustainable Development Goals. It was co-hosted by the governments of Canada and Paraguay, co-organised with six 'child-focused agencies' - ChildFund Alliance, Plan International, Save the Children, SOS Children's Villages International, UNICEF and World Vision International - and endorsed by the Secretary-General's Special Representative on Violence against Children, the African Child Policy Forum, Child Protection in Crisis, End Child Prostitution in Asian Tourism, the Global Initiative to End All Corporal Punishment of Children, Global Movement for Children and Terre des Hommes International Federation. The six child-focused agencies involved in the side event were already working together to advocate for child-focused issues in the post-2015 development agenda. They worked collectively in pursuit of the following goals: (1) eradicating all forms of extreme poverty, (2) tackling inequalities, (3) stopping all forms of violence against children and (4) ensuring locally led and transparent mechanisms for monitoring progress and ensuring accountability (MacDonald 2014).

The aim of the side event was to focus media attention and serve as a communication medium for public influence in order to proclaim and highlight that: 'Every child has the right to live and thrive in a safe and caring family environment, free from all forms of violence' (MacDonald 2014). It was billed as 'an important opportunity to bring the prevention and response to violence against children to the debate around the next generation of development goals, and ensure focus, investment, commitment and results for children in every country - because nowhere in the world are they free from abuse, neglect, exploitation and violence' (MacDonald 2014).

The event was co-chaired by Guillermo Rishchynski, Permanent Representative of Canada to the United Nations, and by José Antonio Dos Santos, Permanent Representative of Paraguay to the United Nations. The meeting was opened by the representative of the six child-focused agencies, Jim Emerson, Secretary General of ChildFund Alliance. After welcoming the government co-hosts, the participating children and the speakers, Emerson highlighted the pervasive presence of violence against children, and the importance of the post-2015 development agenda addressing this issue. Emerson emphasised that 'it's not just our organizations saying this. Most importantly, this is a call from children all over the world. 
Children are asking for an end to physical and humiliating punishment; sexual violence and abuse; harmful child work and child marriage; trafficking and other harmful practices'. Both Ambassador Rishchynski and Ambassador Dos Santos then spoke, responding to Jim Emerson's concerns and proclaiming their governments' continued commitment to the child-focused goals of the SDGs (2014).

Following Jim Emerson and the Permanent Representatives, the next speaker was Migena, who joined the meeting via Skype. Migena is a young girl who participated in post-2015 consultation in Albania, organised by SOS Children's Villages International. Migena stressed the importance of children's engagement in the post-2015 process, and highlighted the need for the next generation of development goals to address the different forms of violence, exploitation and abuse against children. She pointed out the need to take measures for the protection of children from violence, including more awareness-raising about this issue, and more periodical control on the part of state agencies in the areas where violence occurs. 'Please use the information we are giving you, to make the change we want to see for a better future world', Migena concluded (2014).

The side event then proceeded via an 'interactive panel', moderated by an Al Jazeera journalist, Ms. Femi Oke. The panel took place in front of an audience of more than 80 people, which included representatives from UN member states, UN entities and civil society organisations, including INGOs and FBOs. The panellists answered questions from the audience in New York and online, who engaged in the event via Twitter. After the panel, Ms. Diah Saminarsih, from the Office of the President's Special Envoy on Millennium Development Goals, Republic of Indonesia, closed the side event. Ms. Saminarsih took the opportunity to reaffirm Indonesia's commitment to women, youth and children's protection, and to the inclusion of children's protection from violence as a global priority. 'Let us proceed for development without violence', she concluded (World Vision International 2014).

This side event highlights several aspects of the child-focused agenda of the SDGs. First, it was an event which brought together members of partnerships, alliances and coalitions in order to lobby and enter into direct engagement with decision makers both in governments and at the UN. Second, the side event featured input from children while also being concerned to have a high level of media and communications for public influence, via both the audience in New York and online via Twitter, as well as by the involvement of Al Jazeera.

Our third example is a side event which took place in March 2015 and its follow up a few months later, in June 2015. The aim was to exemplify World Vision's commitment to try to ensure that children's voices were heard in the run up to the SDGs and to highlight the issue for media attention via widespread communication with interested parties. Prior to the March 2015 event, World Vision had helped organise two children's consultation processes, in order publicly to consult with vulnerable children on the draft SDGs. The Global Movement for Children in Latin America and the Caribbean, of which World Vision is a member (along with UNICEF, SOS Children's Villages, Child Fund, Plan International and Save the Children), developed a child-friendly version of the Open Working 
Group proposal for the SDGs and specific targets. The child-friendly version was designed to help children and young people better to understand the 17 proposed SDG goals and to enable them to express their views on them. More than 1,000 children and young people took part in a consultation process on the SDGs in 10 countries in Latin America, using the child-friendly version, and supported by the Global Movement for Children member organisations (World Vision Side Event 25 March 2015).

Following the consultation process, World Vision organised a side event: 'Children speak out on the Sustainable Development Goals' (World Vision Side Event 25 March 2015), which took place on the afternoon of 25 March, 2015, in the UN headquarters. The event was moderated by New York - based, Ms. Arelys Bellorini, Senior Advisor-Advocacy and Partnerships, World Vision. ${ }^{13}$ Attending the event were representatives from two Permanent Missions to the UN, those of Brazil and Chile. The side event featured particular inputs from two teenagers, Maria Antonio from Brazil and Rodrigo from Chile. Both Maria Antonio and Rodrigo spoke about the importance of child-focused goals being pursued with energy and vigour in the SDGs. The representatives of the Permanent Missions responded by reaffirming their commitment for the inclusion of children in the Post-2015 Development Agenda. Two INGOs, Save the Children and ATD Fourth Vision, also stated their importance for child-focused goals in the SDGs, including in relation to poverty alleviation and societal inclusion in the SDGs process. Finally, the Office of the Special Representative of the Secretary-General on Violence against Children spoke, urging 'everyone to hold governments and themselves accountable for the achievement of the SDGs'.

The March 2015 side event was followed up a few months later, in June 2015, when World Vision was involved in facilitating consultation with more than 900 children and young people on the draft SDG Declaration. This was part of a global online consultation organised in 2014-2015 by UNICEF and the 'World We Want' initiative, which sought to facilitate 'Dialogues on the implementation of the post2015 development agenda' (United Nations Development Group n.d.). The multistakeholder the 'World We Want' children's consultation was conducted online which limited the participation opportunities for the most vulnerable children that the SDGs aimed to reach. Within that limiting context, the World Vision consultations were nevertheless recognised as valuable 'since they were among the few offline consultations with children from rural communities, including from fragile, emergency and conflict settings. World Vision's consultation is highlighted in the final report which was shared with UN Member States before the final SDG negotiations'. World Vision's consultations were done in rural locations in seven countries - Central African Republic (CAR), Ghana, Mauritania, Niger, Senegal, Sierra Leone and Zambia. More than 300 internally displaced children were consulted on the SDGs in child-friendly spaces in CAR (World Vision International 2016c; United Nations Human Rights 2016).

The overall importance of the consultation process and the two related side events was to highlight and affirm the importance attached to child-focused goals in the SDGs by governments, FBOs, INGOs and a UN entity, thus underlining 
again the importance of partnerships in the pursuit of child-focused goals in the SDGs.

This section looked at three side events held at or near the UN in New York in 2014-2015. World Vision was centrally involved in each of them. Each of the side events took place in the lead up to the SDGs, during the transition from the MDGs. Their collective purpose was to hear the voices of ordinary children in order to inform government policies in relation to the SDGs and to highlight the importance of INGOs and FBOs in that process.

These side events collectively highlight how World Vision works at the UN, in order both to focus on its campaigns in relation to children and also, most importantly, to try to reduce the distance from what is sometimes referred to as the "UN bubble' ${ }^{14}$ to the concerns and travails of ordinary people, including children, struggling to do the best for themselves often in very difficult circumstances. We saw that World Vision and its partners employ four strategies in the overall context of the SDGs and in particular in relation to the Global Strategy for Women's, Children's and Adolescents' Health and the Global Partnership to End Violence Against Children. On the one hand, this involves side events at the UN aiming to emphasise and build 'partnerships, alliances and coalitions', while also allowing 'lobbying and direct engagement with decision makers'. In addition, the importance of allowing to express their concerns is not only for the benefit of decision makers but also to enable the media to highlight their concerns for increased public influence.

\section{Conclusion}

The UN's liberal-secular focus compels all actors at the UN, including World Vision and other FBOs which wish to influence debates and discussions, to adopt 'appropriate' UN-sanctioned language in their engagements with UN actors. FBOs, such as World Vision, which seek to maximise their influence at the UN typically seek to link up with allies - including, other FBOs, secular NGOs and friendly governments - which share their ideological but not necessarily theological norms, values and beliefs. Some FBOs active at the UN, such as World Vision, manage to achieve persistent influence, via regularised and/or institutionalised access to opinion formers and decision makers located in friendly governments and intergovernmental organisations (for further discussion of these issues, see Barnett and Stein 2012; Boehle 2010; Haynes 2014; Schelenz 2016). By feeding its development priorities and notions into the discursive fields of international development at the UN, World Vision acts as a development entrepreneur (Koehrsen and Heuser 2019 in this volume).

The aim of this chapter was to examine the role of a Christian-orientated development agency, World Vision at the United Nations, in relation both to its Christian foundations and its wider partnerships with other development entities, both secular and faith-based. The chapter sought to determine the extent to which World Vision's general Christian values encourage the organisation to pursue faith-based development goals at the UN, or whether its wider development concerns are for 
the needy, more generally, irrespective of their faith. To do this, we looked at its partnerships and networks with various state and non-state organisations at the UN, including governments, UN agencies, secular INGOs and FBOs.

The chapter evinced World Vision's history and development over the last seven decades, since its starting point in 1947. Over time, it has progressed from being a very small, explicitly Christian, humanitarian organisation with an interest in children in China alone, to becoming a global development agency with an annual income of more than US \$1 billion and employing 46,000 people around the world. World Vision especially targets individual Christians via its appeals, mainly from its website, while also engaging with state and other institutional agencies, to seek funding for its child-orientated development activities. Different language is used in each context, with notably more 'Christian-focused' language in its financial appeals to individual donors, compared to the language it employs in relation to state and other institutional entities (Tedham 2012). The flexible adaptation of its language enable World Vision to successfully moving in different discursive fields. The organisation has become an efficient boundary agent that bridges diverse discursive fields (Koehrsen and Heuser 2019 in this volume).

A second key concern of the chapter was to examine why, how and with what outcomes World Vision engages with the secular and faith-based, state and nonstate, development community at the UN. We saw that World Vision focuses much effort on activities at the UN, using the UN as a focal point of its partnerships, alliances and coalitions, as well as a key environment for lobbying and direct engagement with decision makers. During the last two decades, in the context of the MDGs and the recent transition to the SDGs, World Vision has been centrally involved in organising side events at the UN. We saw that such side events are a significant way not only to include children's and youth participation in its activities but also to seek to influence media and communications for public influence.

Evidence presented in the chapter suggests that World Vision spends much time, energy and significant financial resources at the UN on short-, medium- and long-term development needs of the most vulnerable and needy constituencies in the Global South: poor women and children. A key outcome of World Vision's financial, organisational and territorial focus over time at the UN is that it appears to have the capacity to positively influence development outcomes. While World Vision's Christian roots continue to influence its thinking, it focuses resources at the UN where they are most needed rather than in the direction of Christians and to the detriment of those of other faiths.

\section{Notes}

1 US $\$ 5$ in 1950 was worth the equivalent of c.US\$50 today.

2 'MinistryWatch.com profiles Public Charities, church and parachurch ministries. It is also a place to learn about how to be a responsible giver. MinistryWatch.com is an independent donor advocate facilitating the information needs of donors. It provides information on organizations alleging to be charitable and its key leadership in order to identify materially misleading behavior, or wasteful spending practices, 
as well as identifying those operations that are above board and running efficiently' (MinistryWatch).

3 Interview with Sarah Pickwick, World Vision UK Senior Conflict Adviser, London, 3 March 2015.

4 Interview with Mae Elise Cannon, Senior Director of Advocacy and Outreach, World Vision, Washington, DC, 27 January 2012.

5 Interviews with Daanish Masood, 27 January 2016, Politics Affairs Officer at the United Nations, and Azza Karam, Senior Advisor on Culture at the United Nations Population Fund, New York, 28 January 2016.

6 MDGs are listed at End Poverty.

7 SDGs are listed at Sustainable Development Knowledge Platform.

8 Interview with Arelys Bellorini, World Vision Senior Advisor on Advocacy and Partnerships, New York, 26 January 2016.

9 'The BabyWASH Coalition is a group of organisations focused on increasing integration between water sanitation and hygiene (WASH), early childhood development (ECD), nutrition, and maternal newborn and child health $(\mathrm{MNCH})$ programming, policy-making and funding to improve child well-being in the first 1000 days' (BabyWASH Coalition).

10 Interview with Cathy Turner, World Vision UK's Child Rights Policy Manager, London, 14 February 2016.

11 World Vision's main advocacy efforts take place at the UN in New York. In addition, the organisation has an office in Geneva, home to several UN and other specialised agencies, including: International Committee of the Red Cross, Office for the Coordination of Humanitarian Affairs, UN Human Rights Council, UN Refugee Agency, World Health Organization and World Trade Organization. 'World Vision's Geneva office works to influence United Nations programmes and specialized agencies, as well as other decision-makers based in the city, in order to connect policy with practice to achieve the fulfilment of the rights of the most vulnerable children of this world' (World Vision International).

12 The countries were: Albania, Brazil, Bangladesh, Malawi, Mexico, Pakistan, Sierra Leone, Somalia and Uganda. No information is available regarding who the children were or from which communities they came.

13 Interview with Arelys Bellorini, World Vision Senior Advisor on Advocacy and Partnerships, New York, 26 January 2016.

14 Interviews with Katherine Marshall, former senior World Bank official and author of Marshall (2013), Oslo, 20 December 2015, and Azza Karam, Senior Advisor on Culture at the United Nations Population Fund, New York, 28 January 2016.

\section{References}

ACT Alliance, 2015. The Role of Faith-Based Organizations in Humanitarian Response. A Reflection on the Unique Role of FBOs in Humanitarian Crises [online]. Available from: http://programme.christianaid.org.uk/programme-policy-practice/sites/default/ files/2016-03/role-of-faith-based-organizations-in-humanitarian-response-reflection.pdf [Accessed 25 August 2016].

BabyWASH Coalition [online]. Available from: http://babywashcoalition.org/ [Accessed 5 May 2018].

Barnett, M., 2012. Faith in the Machine? Humanitarianism in the Age of Bureaucratization. In: M. Barnett and J. Gross Stein, eds. Sacred Aid: Faith and Humanitarianism. Oxford: Oxford University Press, 188-220.

Barnett, M., and Stein, J., eds., 2012. Sacred Aid: Faith and Humanitarianism. Oxford: Oxford University Press. 


\section{Jeffrey Haynes}

BBC News, 2015. Syria's Beleaguered Christians [online]. Available from: www.bbc. co.uk/news/world-middle-east-22270455 [Accessed 25 August 2016].

Benthall, J., 2012. "Cultural Proximity" and the Conjuncture of Islam with Modern Humanitarianism. In: M. Barnett and J. Stein, eds. Sacred Aid: Faith and Humanitarianism. Oxford: Oxford University Press, 65-89.

Boehle, J., 2010. The UN System and Religious Actors in the Context of Global Change. CrossCurrents, 60 (3), 383-401.

Byworth, J., 2003. World Vision's Approach to Transformational Development: Frame, Policy and Indicators. Transformation, 20 (2), 99-111.

End Poverty. News on Millennium Development Goals [online]. Available from: www. un.org/millenniumgoals/ [Accessed 5 May 2018].

Every Woman Every Child, 2016. UN Secretary-General Announces Members of the HighLevel Advisory Group for Every Woman Every Child. Davos, Switzerland.

Haynes, J., 2007. Religion and Development: Conflict or Cooperation? Houndmills, Hampshire: Palgrave Macmillan.

Haynes, J., 2013. Introduction to International Relations and Religion. London: Pearson.

Haynes, J., 2014. Faith-Based Organizations at the United Nations. New York, NY: Palgrave Macmillan.

Heist, D., and Cnaan, R.A., 2016. Faith-Based International Development Work: A Review. Religion, 7 (19), 1-17.

Hopgood, S., and Vinjamuri, L., 2012. Faith in Markets. In: M. Barnett and J. Stein, eds. Sacred Aid: Faith and Humanitarianism. Oxford: Oxford University Press, 37-64.

Howard, P. "Humanitarian aid organizations and sustainable development." Paper presented at the G20 Interfaith Summit Meeting, Istanbul, Turkey, 18-20 November 2015.

Jenkins, K., 2015. Talking About Faith at the UN Assembly [online]. Available from: http:// www/wvi.org/presidents-page/article/talking-about-faith-un-assemply [Accessed 18 August 2016].

Jones, B., and Petersen, M.J., 2011. Instrumental, Narrow, Normative? Reviewing Recent Work on Religion and Development. Third World Quarterly, 32 (7), 1291-1306.

Joshi, D., Kay O'Dell, R., and Kay, R., 2013. Global Governance and Development Ideology: The United Nations and the World Bank on the Left-Right Spectrum. Global Governance: A Review of Multilateralism and International Organizations, 19 (2), 249-275.

Koehrsen, J., and Heuser, A., 2019. Beyond Established Boundaries: FBOs as Developmental Entrepreneurs. In: J. Koehrsen and A. Heuser, eds. Faith Based Organisations in Development Discourses and Practice. London: Routledge.

MacDonald, A., 2014. A World Without Violence Against Children [online]. Available from: http://childfundalliance.org/a-world-without-violence-against-children-2/ [Accessed 25 August 2016].

Marshall, K., 2013. Global Institutions of Religion: Ancient Movers, Modern Shakers. London, New York, NY: Routledge.

Meyers, B.L., 2011. Walking with the Poor: Principles and Practices of Transformational Development. Maryknoll, NY: Orbis Books.

MinistryWatch. About MinistryWatch [online]. Available from: https://ministrywatch.com/ about.php [Accessed 16 May 2018].

Mueller, J., 2016. Reforming the United Nations. A Chronology. Leiden, Boston: BRILL.

Partnerships for the SDGs, 2016. Global Partnership to End Violence against Children [online]. Available from: https://sustainabledevelopment.un.org/partnership/?p=9061 [Accessed 25 August 2016]. 
Plan International, 2016. Our History [online]. Available from: https://plan-international. org/organisation/history [Accessed 24 July 2016].

Save the Children, 2016. Our History [online]. Available from: www.savethechildren.org. uk/about-us/history [Accessed 24 August 2016].

Schelenz, L., 2016. How Meaningful Participation of Children and Youth Can Lead to Peace: Building a Theory and Developing Practical Suggestions. Background Paper. Friedrichsdorf, Germany: World Vision Institute.

Secretary General, 2010. Secretary-General's Video Message to World Vision Korea on Its 60th Anniversary [online]. Available from: www.un.org/sg/en/content $/ \mathrm{sg} / \mathrm{state}$ ment/2010-10-11/secretary-generals-video-message-world-vision-korea-its-60th [Accessed 25 August 2016].

Side Event on A World Without Violence Against Children, 2014 [online]. Available from: https://sustainabledevelopment.un.org/content/documents/3218Joint\%20Side-event.pdf [Accessed 25 August 2016].

Side Events, 2016. UN Women [online]. Available from: www.unwomen.org/en/csw/ csw58-2014/side-events\#sthash.nrEmc3gM.dpuf [Accessed 25 August 2016].

SOS Children's Villages. History [online]. Available from: www.sos-childrensvillages.org/ who-we-are/about-sos/history [Accessed 24 August 2016].

Sustainable Development Goals, 2015 [online]. Available from: https://sustainabledevel opment.un.org/?menu=1300 [Accessed 25 August 2016].

Sustainable Development Knowledge Platform. Sustainable Development Goals [online]. Available from: https://sustainabledevelopment.un.org/index.php?menu=1565 [Accessed 5 May 2018].

Tedham, A., 2012. Charitable Giving, Fundraising, and Faith-Based Organizations: Islamic Relief World Wide and World Vision International-A Comparison. Working Papers in International History. Graduate Institute of International and Development Studies, 20 (11), 2013.

UNICEF, 2012. Partnering with Religious Communities for Children. New York, NY: UNICEF.

United Nations Development Group, n.d. The World We Want. Dialogues on the Implementation of the Post 2015 Development Agenda [online]. Available from: www.un.org/ millenniumgoals/pdf/UNDG\%202nd\%20dialogues.pdf [Accessed 25 August 2016].

United Nations Human Rights, 2016. Office of the High Commissioner. A Human Rights Approach to Reducing Child Deaths [online]. Available from: www.ohchr.org/Documents/ Issues/Women/WRGS/Health/TGApplicationHumanRights.pdf [Accessed 17 May 2018].

Ware, V.-A., Ware, A., and Clarke, M., 2016. Domains of Faith Impact: How "Faith" Is Perceived to Shape Faith-Based International Development Organisations. Development in Practice, 26 (3), 321-333.

Wet, H.L. de, 2011. Understanding Transformational Development in World Vision South Africa: Conceptualisation and Operationalisation. The Hague, The Netherlands: Erasmus University.

Wet, H.L. de, 2013. Transformational Development: World Vision South Africa's Response to Poverty. International Development Policy: Religion and Development, 4, 95-111.

Whaites, A., 1999. Pursuing Partnership: World Vision and the Ideology of DevelopmentA Case Study. Development in Practice, 9 (4), 410-423.

World Bank, 2000. Voices of the Poor. Washington, DC: World Bank.

World Vision. World Vision Financial Highlights [online]. Available from: www.worldvi sion.org/about-us/financial-accountability\#1468438460787-19569590-8c21 [Accessed 4 May 2018]. 


\section{Jeffrey Haynes}

World Vision, 2016. A Human Rights-Based Approach to Reducing Child Mortality and Morbidity. A Snapshot of World Vision's Contribution [online]. Available from: www. ohchr.org/Documents/Issues/Children/. . .WorldVision.doc [Accessed 25 August 2016].

World Vision International. Geneva [online]. Available from: www.wvi.org/world-visionun/geneva [Accessed 5 May 2018].

World Vision International, 2013. Children Weigh in on the World they Want Post-2015 [online]. Available from: www.wvi.org/united-nations-and-global-engagement/pressre lease/children-weigh-world-they-want-post-2015 [Accessed 25 August 2016].

World Vision International, 2014. Report: A World Without Violence Against Children [online]. Available from: www.wvi.org/united-nations-and-global-engagement/article/ report-world-without-violence-against-children [Accessed 25 August 2016].

World Vision International, 2016a. All Commitments [online]. Available from: www. everywomaneverychild.org/commitments/world-vision-international [Accessed 24 August 2016].

World Vision International, 2016b. Our History [online]. Available from: www.wvi.org/ our-history [Accessed 24 August 2016].

World Vision International, 2016c. Our Values [online]. Available from: www.wvi.org/ vision-and-values-0) [Accessed 24 August 2016].

World Vision International, 2016d. Where We Work [online]. Available from: www.wvi. org/where-we-work [Accessed 24 August 2016].

World Vision Side Event, 2015. Children Speak Out on the Sustainable Development Goals [online]. Available from: https://sustainabledevelopment.un.org/content/ documents/6861 summary1.pdf [Accessed 17 May 2018]. 


\title{
5 Giving and development \\ Ethno-religious identities and 'holistic development' in Guyana
}

\author{
Sinah Theres Klo $\beta^{1}$
}

\section{Looking for FBOs}

When I first contacted Prakash ${ }^{2}$ in September 2012, I had just seen his advertisement of a clothing drive that he was organizing and which he was announcing on Facebook. In this post, he explained that he was collecting used and new garments in the surroundings of his New York - based home, to then ship them to Guyana, where he would hand them out to the 'poor' and 'needy'. Prakash is a young Guyanese Indian man in his thirties, who migrated from the Guyanese countryside to Queens in New York with his family in the 1990s. Having been educated in the USA and having graduated from a local college, he was able to 'make something good' of his skills and therefore started to organize charitable projects and to volunteer for various humanitarian and development organisations in Guyana. Among these organisations was the Save Abee Foundation (SAF), which I refer to in detail later in this chapter. As I was seeking to understand the shifting power dynamics between Christian and Hindu social actors in Guyana, and particularly how power relations are negotiated through clothing (re-)distributions, I had contacted him to learn about his motivation for conducting a clothing drive (Kloß 2017). He replied to my enquiry via email, explaining that his motivation is based on the fact that he is a Hindu, and that it is his dharma to 'serve humanity' and 'keep up' his traditions to ensure that future generations will maintain them and not 'stray away from our such rich culture' (personal communication 3 Sep 2012). Dharma is a central concept in Hindu philosophy that has manifold meanings, from " "truth" and "order" (both cosmic and social), to "law" (both universal and particular), "teaching", "duty", "virtuous behaviour", and "religion"' (Johnson 2010, p. 102). According to Prakash and many other Hindu informants, clothing (re-)distributions were necessary as organisations - which he labelled as Christian - used charitable distributions of food and clothing as a means to convert Hindus to Christianity, a discourse I return to later. Although charitable distributions, labelled as Christian, seem to have largely diminished in the coastal areas of Berbice, they continue to exist in the imagination of my informants, are frequently interpreted as 'conversion strategy', and have become part of their collective memory of Hindu inferiorization in Guyana (Kloß 2017). 


\section{Sinah Theres Klo $\beta$}

Having described his volunteer work in terms of challenging Christianity - particularly Christian mission work - and by specifically declaring his perspective and practices as those of a Hindu, I immediately considered him as a potential informant for my most recent anthropological research on concepts of development in faith-based organisations (FBOs). In this new research project - part of which appears as this chapter - I analyzed how religious identities and processes of ethno-politicization influence concepts of 'development' in Guyana. For this purpose, I conducted anthropological fieldwork on the East Coast Demerara and in Georgetown, Guyana, for four months in 2015 engaging in participant observation and ethnographic interviews. Throughout this period and also drawing from my previous research experience in Guyana, I was able to spend time in various rural and urban Christian communities - particularly with Seventh Day Adventists - as well as within rural Hindu communities. I accompanied and interviewed employees and volunteers of several faith-based and non-governmental organisations. Having made his acquaintance only virtually through email and Facebook, I was fortunate to meet Prakash in August 2015 at a medical outreach programme, which SAF co-hosted with the Nirvana Humanitarian Society (NHS) in the village Meten-Meer-Zorg. When I arrived in the buzzing community centre, a few hundred people - NHS and SAF volunteers, medical doctors, and patients with their families - had already gathered, offering or receiving medical checkups. Particularly high in demand were tests of blood sugar and blood pressure. Deservedly proud, Prakash showed me the arrangements for the one-day clinic and introduced me to other volunteers. After he had handed me a T-shirt with the Save Abee logo, marking me as an official volunteer, he provided me with some general information about the foundation and event. When I asked him almost randomly if he defined the organisation as a faith-based organisation, he immediately negated. Save Abee, like Nirvana, he commented, were not 'religious organisations', but instead were 'open to all' and not specifically Hindu or directed towards Hindus. Being somewhat surprised at his seemingly sudden distancing from religion, only later did I realize that I had spoken, classified, and interpreted his motives and ongoing actions of the organisations from my Western European background and on the basis of current academic discussions about classifications concerning FBOs and NGOs (Clarke 2006, 2008; Occhipinti 2015). Questions of definition in mind, I had approached my field and informants 'looking for' FBOs - expecting to find some - but was reminded that possibly no such thing may be found in the Guyanese context, where classifications of organisations are not necessarily based on a faith-based/secular distinction.

To the great majority of my informants, both Hindu and Christian, a person cannot be irreligious, and as organisations are constituted, maintained, funded, and brought into action by people who necessarily belong to one of the many religious traditions, organisations must be faith-based in one way or the other. My informants usually reject the differentiation of secular and religious/spiritual spheres of life. To them, there exists nothing outside of the spiritual or the religious, and even science is no secular sphere in which deities and/or spirits are restricted from exerting influence. To them, there exists only an overall religious/spiritual 
sphere that is life and creation. Spirituality is expressed in specific daily routines, such as following dietary rules, sexual restrictions, or adhering to specific sartorial practices. To follow these necessary modes of behavior, a person has to adapt his or her entire lifestyle and cannot compartmentalize or differentiate religious and secular spheres of life. Particularly Hinduism is considered to be immanent to and inseparable from the everyday. Not only do Hindus emphasize this as a characteristic of their traditions, but Christians also sometimes admiringly speak about this 'spiritual' side of Hinduism and describe it as 'virtuous'. Additionally, in informal conversations political activists and scholars comment that Hinduism is all-encompassing for Hindus. Thus, one scholar points out that

[o]ne of the differences between African religions and religious practices and Hindu . . . is that . . f for Hindus, Hinduism is all of them. There is no separation between the church and them. Among Christians, you go to church on Sundays, and on the rest of the week you are secular. . . But for Hindus is a 24/7 thing.

(Daniel, personal interview)

Hinduism is thus often portrayed as 'more worldly' than Christian religion. Certainly, this is viewed differently among members of the various Christian denominations and for example Pentecostals or Seventh Day Adventists would disagree and emphasize their spiritual lifestyles in which religion is a '24/7 thing' (Jacob, personal interview). The emphasis on diet and nutrition among Seventh Day Adventists is frequently pronounced in conversation with Adventists, in which vegetarianism and abstinence from alcohol is most commonly referenced. The relevance of nutrition for Seventh Day Adventists is also discussed in brochures available for purchase in the local SDA bookstore in Georgetown, such as 'A Call to Medical Evangelism and Health Education' (White 2010), in which the preparation of 'healthful' and 'wholesome' food is promoted. For example, my informant Michael, who converted to Seventh Day Adventism 'a few years ago', is in his thirties, lives on the outskirts of Georgetown, and works in an administrative position in the agricultural sector, frequently explained his dietary plans and his ideas of healthy living to me. His emphases on nutrition certainly contained educational messages, but he also applied them as expressions of his belief in Seventh Day Adventism and as proof for the genuineness of his faith, as it influences his everyday life and routines. In this sense, no clear line may be drawn between Hindu and SDA perceptions concerning their views on their faiths' impact on daily life. However, they both strongly differentiate between themselves and orthodox Christian traditions, such as Catholicism and Anglicanism, whose members, according to them, distinguish between secular and religious spheres of life.

Hindu and Adventist perspectives on spirituality challenge the distinction between the secular and the religious that is also part of (Western) definitions of FBOs. To apply a differentiation of FBO and NGO may be a misleading approach in contexts, in which the majority of social actors do not differentiate between secular and religious spheres of life. This is opposed to Western European contexts, 


\section{Sinah Theres Kloß}

in which more people define themselves as secular. Therefore, for my further research, I found it necessary to refuse an 'a priori distinction between secularism and religion' (Fountain 2013, p. 26), in order to provide a context-sensitive study of religion and development, as has been called for in recent publications (Tomalin 2012). Social actors may strategically apply the categories FBO and NGO in varying contexts, for example if donors prefer to build relationships with organisations that promote a specific secular or faith-based identity. On the other hand, concerning development and humanitarian work, social actors frequently play down religious identities or reject the label 'FBO' altogether. This may be the case when organisations are mistrusted on the basis of alleged proselytization motives or, in general, when religion is considered a 'sensitive issue' (Tomalin 2012, p. 694). In the tense and contested ethnic environment of Guyana, Prakash's variable labelling of SAF reveals that classifications of development organisations have to be considered as contextual and strategic.

This chapter is based on the case study of two 'development organisations' operating in Guyana: the Save Abee Foundation (SAF) and the Adventist Development and Relief Agency (ADRA). These organisations were selected after an assessment of the various organisations active in Guyana, and for their willingness to engage in the research project. SAF is a non-profit organisation, which was registered in the USA in 2010 and operates in rural areas of Guyana. It was founded by a Guyanese migrant, who today resides in Florida with his family but who frequently travels to Guyana to conduct SAF projects together with his wife. Initially, SAF opened a centre for children in Cotton Tree Village, West Coast Berbice, in order to provide computer education classes. While its official mission, as stated on the website, continues to focus on children, ${ }^{3}$ SAF projects have diversified over the past years and now include, for instance, charitable distributions of clothes or toys and medical outreach programmes. SAF has expanded these programmes to various other villages in the coastal areas of Guyana (Save Abee Foundation 2016, August 13, 2015). The foundation conducts fundraising shows and parties, usually in the Guyanese diaspora in the USA and Canada through the sales of tickets, supported by popular Indo-Guyanese artists.

ADRA is a transnational organisation with headquarters in the USA and is an agency of the Seventh Day Adventist Church (SDA). According to the SDA Guyana Conference, a sea captain was asked to distribute SDA pamphlets at the docks of Georgetown as early as 1883, founding the basis for the SDA Church in Guyana. ${ }^{4}$ Various missions and the continued dissemination of literature followed and led to the opening of the first churches in the late 19th century. In 1906, the British Guiana Conference was established, comprising 12 churches and 350 members. In 2016, the SDA Guyana Conference counted approximately 60,000 members, divided into 209 congregations and 27 pastoral districts (Guyanaadventists). SDA Guyana defines itself as a multi-cultural and multi-ethnic organisation (Kaieteur News 2015a). The self-reliant Guyanese section of ADRA is currently setting up its programmes from the head office in the capital Georgetown. Ideas for projects were collected in SDA churches and community centres by SDA representatives. Current and future projects include the building of 
physical infrastructure - such as water wells, mobile sawmills, water tankers, bridges, or a cassava industrial factory - as well as training programmes for farmers, a youth centre, or counselling services. These projects are located both in the so-called 'interior' (Guyanese hinterland) as well as the coastal areas of Guyana, here mostly in rural areas.

Both organisations do their own fundraising and are transnational in character, as head offices are located in the USA and employees and/or volunteers frequently travel between Guyana and North America (see Koehrsen and Heuser 2019 in this volume). As discussed later, they import specific know-how, organisational structures, concepts of governance and leadership, and consequently concepts of development that are adapted locally. Both SAF and ADRA described their objectives and programmes in terms of improving and building physical infrastructure, education and schooling, as well as health facilities and health education.

Describing no specific differences in their programmes and objectives, it would seem obvious to consider the organisations as doing 'the same'. But when paying attention to the specific context of Guyana and when reflecting the situation of religious competition and the seemingly insurmountable link between ethnic and religious identities that extends not only to people and parties but also organisations - as discussed later - one may start to wonder whether these practices are indeed the same. Therefore, this chapter raises questions such as: If different organisations, each labelled as belonging to a different ethno-religious tradition, claim to say or do the same thing, is this really the case? If one takes their different social positioning, the historical background, and past and present power relations into consideration, do they perhaps instead challenge established power structures and socio-religious hierarchy? What is the relevance of giving and the notion of holistic development in this context? To understand the significance of doing and giving development in the context of challenging the established social hierarchy, I first discuss the notion of holistic development according to my informants, provide a socio-historical background by describing Guyanese ethno-religious identities and groups, highlight how these different groups compete in local systems of power, in nation-building and in processes of ethno-politicization, and discuss the notion of leadership.

\section{The notion of holistic development}

Definitions and interpretations of what is understood as development change and transform over time. Certainly, there are also different views and opinions on what is development among the various social actors and organisations. Numerous Guyanese apply the term development in terms of transformation and growth at present. The majority of my informants explained that development is a process which becomes manifest and materializes in physical infrastructure such as roads, houses, shopping malls, or airports. This does not imply that they consider spiritual enhancement and development as less significant. When directly enquiring what development means, they usually listed growth and the increasing availability of material goods first. For example, Premwattie, who is an 80-year-old 


\section{Sinah Theres Klo $\beta$}

Guyanese Indian Hindu widow living with one of her daughters and son-in-law in a small wooden house in rural Berbice, picked up a plate from the table, held it up in the air, and answered my question stating: 'Development mean: like you get this plate, and you nuh get more than this plate, but if you get more than this plate . . . is development' (personal interview). She further interpreted development in terms of status enhancement and the transformation of living conditions and social hierarchy, stating that, 'Development mean you ah get up in life' (Development means you rise in/enhance your status).

Although at first statements like Premwattie's seem to indicate material expansion only, my informants further indicated the intricate link between development and spirituality or religion. In this way, and although economic development is still frequently referenced as an indicator of national development, my informants pronounced broader definitions of, and more holistic approaches to development. For instance, following her explanation of material expansion and growth, Premwattie added that material and personal enhancements are processes which are directly linked to 'god and prayers'. She elaborated that you 'get up in life by devotion to god' (you raise your status while alive/you raise your status in society by devotion to god) and that, 'god nuh mek beggarmen, you put yuhself suh' (god does not make beggars, you put yourself into that position/condition). As Premwattie is a Hindu and has expressed her belief in karma before, her statement also indicated the influence of reincarnation on personal development, as she referred to the consequences of spiritual behavior for past, present, or future lives.

Seventh Day Adventist Jacob - who holds a leading position at ADRA, a 55-year-old 'Indian'5 man, lives with his family in the countryside, travels to the SDA head office in the capital every day, and expressed different concepts of life - highlighted the need to consider development as 'holistic'. This, according to him, includes a spiritual dimension. Commenting on concepts of development, he emphasized that he prefers 'holistic approaches' that require looking not only at the material aspects of development. According to him, spiritual development is an 'integral part' of development, as 'not all aspects of life that are of relevance are visible' (personal interview). His statement is indicative of the international discourse on holistic development, which developed in order to divert the attention from solely economic and material development to additionally containing cultural aspects and subjective understandings of wellbeing. The notion of holistic development includes

macroeconomic management, global democratization and planetary ethics. Identifying with the whole means that development can no longer be simply geared to material aims and achievements but includes non-material dimensions, as in cultural development. It means that development can no longer be anthropocentric but encompasses the planetary ecology. Stretching the meaning of development to its fullest, it may be summed up as a collective learning process of human self-management according to the most comprehensive standards conceivable and practicable. 
Such understandings of development, which include human wellbeing and environmental sustainability, has broadened particularly since the 1980s (Freeman 2012).

Both my Christian and Hindu informants commented that a sole focus on material aspects would be short-sighted, as upon death a person has to leave all material goods behind and may only 'take along' his or her spiritual achievements such as merit. For example, Premwattie highlighted that 'reincarnation is an eternal thing', that a person is 'just passing through this one [life]' but that, when 'you have to die, you leave all of that'. According to her, material objects are like a cage or a spider web that create 'material ties'. People should instead prefer 'more simple ways' of living and turn away from an orientation on things. Jacob, although as a Christian not referring to reincarnation, similarly discussed that spiritual wealth is the only good a person keeps or that will be of benefit to him or her when he or she dies. The higher a person develops spiritually, the purer will be his or her thoughts and intentions, and the more he or she will be in line with his social and natural environment. According to the interviews conducted, to the majority of Guyanese, regardless of their religious affiliation, holistic development thus requires and refers to a 'change of mindset' (spiritual development) that ultimately leads to material expansion, for instance the expansion of physical infrastructure, which is combined with the growth of social, cultural, and economic capital. ${ }^{6}$

The notion of spiritual development as part of 'holistic development' is not particular to devout Christians, Hindus, or Muslims in Guyana. Besides religious groups, another group of social actors applies the notion of spiritual development. Social actors who actively engage in nation-building processes or (postcolonial) scholars often discard 'Western' imperialist tendencies by emphasizing and prioritizing the notion of spiritual development, opposing spirituality to religion. For instance, Kwesi, a Guyanese postcolonial and Africanist scholar who today lives in the UK and whom I met during the lecture series 'Restoration of African Pride in Guyana', where he also presented, commented that the

spiritual development of a people is extremely important. . . . If you don't have spiritual development, you only have material expansion. . . . Spiritual development is the development of the totality of the human being, their relations with themselves, other people, and the environment. Their whole understanding of cosmos.

(Personal interview)

Highlighting that development has to be understood as holistic, a combination of spiritual and material, he emphasized that it must occur in accordance with the environment. According to Kwesi, development cannot happen 'away from nature', but needs to be in line with it. While in Europe, material and cultural development may be noticed, spiritual development does not exist to the extent it would be necessary to achieve sustainable, holistic development. Spiritual development, accordingly, is what makes material development sustainable and thus 
effective in the long run. Material development, he continued, forms a prerequisite to or basis for spiritual development; it provides a specific level of comfort that is necessary to develop spiritually. The 'West' threatens its development process by destroying the environment and ignoring the fact that humanity is part of it. Similar views were expressed by my Hindu and Christian informants, including the employees and volunteers of SAF and ADRA.

In Guyana, the emphasis on spirituality and spiritual development furthermore has to be understood as part of anti-imperial and anti-colonial discourse and practice. It is further linked to anti-religious discourse. Social actors often interpret religion as an orthodox structure and as an imposition of former colonizers on colonized people. They discuss how colonized people were stripped of their spirituality and 'original' spiritual traditions, proposing that former colonial governments and populations lacked spirituality. Some argue that this imposition continues today and that particularly Christianity has always been a means of Western nations to maintain their dominant status positions in global power relations. While regarding religion as something that is imposed on people and that is linked to discipline, institutions, and division, they define spirituality as a process of self-realization, (individual) transformation, and as something that is linked to unity, individuality, and human equality.

While this discourse is particularly prominent among Guyanese African Christians, Guyanese Hindus also refer to this opposition of religion and spirituality. A large proportion of my Hindu informants reflected on religion as something hypocritical in opposition to spirituality. For instance, they often stress that their beliefs are 'no religion' but instead have to be understood as 'ways of life'. Such statements are usually embedded in the discourse of the 'invention' of Hinduism as a religion. Frequently, Guyanese pandits (Hindu priests) point out the history of how the term Hinduism had been invented by colonizers during the various phases of Mughal and British invasions of India. They often explain that 'Hindu' originally translates to 'a person who lives beyond the river Indus', and highlight that the various Hindu traditions were labelled in opposition to non-Hindu beliefs and systems of classification (Fuller 2004; Michaels 2004). Even within the heterogeneous Guyanese Hindu population, the different Hindu traditions contest their validity and legitimacy on the basis of degrading other traditions as 'religion' and claim that their own traditions are 'ways of life'. They point out the other traditions' syncretism and supposed lack of authenticity. For example, Seeram, a 62-year-old cane worker and convinced follower of the local 'Madras tradition'a marginalized shaktistic tradition that combines elements of healing, manifestation of deities, and animal sacrifice (Kloß 2016) - commonly emphasized that as a Madrassi, he has to adapt his daily habits and his 'way of life' in order to fulfill the requests of the deities. In contrast to this and according to him, adherents of the mainstream, orthodox Sanatan tradition supposedly compartmentalize their lives by only adapting their lifestyles on Sundays or even only on Sunday mornings. According to him, such practice is superficial and inauthentic, more 'like religion'. As addressed earlier, Seeram thus claimed superior status on the basis of living a spiritual instead of a religious life, which would imply notions of 
secularism. He differentiated the various Hindu traditions similar how Adventists oppose themselves to orthodox Christians. These internal negotiations, intricate to all denominations, challenge the established socio-religious hierarchy, as for instance Seeram claimed higher morality and authenticity on the basis of living a spiritual - not a religious - life.

\section{Ethno-religious identities and competition}

In light of these critical perspectives on 'religion', it is not surprising that in Guyana there exist ambivalent perspectives about whether and to what extent religion may support national development and nation-building. Some Guyanese highlight religion's particular capacity to unite people, as it promotes morality, respectability, and familial and communal values, which they claim to be the core of all religions. For example, Jacob of ADRA emphasized that religion should not be regarded as a barrier, but a bridge, and that 'religion is a key ingredient to bring people together' (personal interview). Others, however, remained sceptical or openly questioned the unifying character of religion, stressing that religion more often creates tensions, borders, and rupture. Regardless of their perspectives, they usually agreed that inter-ethnic tensions and a lack of social cohesion hinder Guyana's development (Nascimento 2000). Although they listed various factors that restrict the development - for example the extensive outward migration and the related brain drain, the remoteness of some hinterland communities, corruption, the lack of industrial production, deficient health care and educational systems they emphasized that social cohesion among the ethnic groups is a key aspect for local socio-economic development.

When engaging in conversations on opportunities for and challenges to development, informants - including SAF and ADRA representatives - usually described the lack of national unity and the incomplete nation-building process that fails due to a lack of 'good governance'. They highlighted that whichever government is in charge, it has to invest in specific domains and industries that are no longer economically feasible but remain of crucial relevance in the construction of ethno-religious identities. Despite the often-proclaimed slogan 'Sugar is dead', any action 'against' the sugar or rice industry, such as cutting state subsidies, is considered an affront against the Indian ethnic group, as the agricultural sector is significant to the construction of Indian ethnic identity. 'Ethnically, you cannot let it down', Daniel explained and continued his elaboration by stating that 'sugar is now a prisoner of our ethnic politics' (personal interview). Similar observations were pronounced in an informal conversation with a prominent figure of the Guyanese rice sector, who wishes not to be named. The significance of social cohesion for national development was furthermore highlighted by the first actions of the newly elected government, which included the renaming and restructuring of ministries, such as the Ministry of Social Cohesion, created to foster a 'more positive' inter-ethnic environment in May 2015 (Kaieteur News 2016; Kaieteur News 2015b). For instance, President David Granger explained the government's structural changes as a way to emphasize a turn towards involving the community in 
plans of development: 'We hope to infuse the feeling of community solidarity and provide not only physical facilities but social and cultural facilities to transform the communities' (Kaieteur News 2015b). Highlighting that both physical and socio-cultural facilities are required to transform the nation and its communities, he indicates the locally adapted notion of 'holistic development'.

Indeed, ethnic identities fundamentally impact all aspects of Guyanese life. They consolidate in different ethnic groups, which in contemporary Guyanese society are: Indian, African, Chinee (Chinese), Potogee (Portuguese), Amerindian (indigenous), and European/White. According to the 2012 census, 'Indians' and 'Africans' form the two biggest groups with $39.8 \%$ of the population categorized as 'Indian' and an 'African' percentage of 29.3 (Bureau of Statistics 2012). ' Guyanese ethnic groups construct their ethnic identities mostly on the idea of shared common descent. ${ }^{8}$ For example, Indians - sometimes also referred to as East Indians - define themselves as descendants of Indian indentured laborers, who were shipped from British India to the Caribbean between 1838 and 1917 to work on sugar plantations after the abolition of slavery in the British Empire. Africans, on the other hand, define enslaved Africans as their ancestors, who had been forced to the Caribbean prior to the system of indentureship. These ethnic groups as well as concepts of 'Indianness' and 'Africanness' have to be considered as social constructions, as they are defined and continuously reconstructed by social actors, cultural practices, and discourse (Williams 1991; Kloß 2016). They are based on othering processes and in relation to each other (Hall 2000), with the African and Indian ethnic groups forming constitutive others (Premdas 1992; Ramey 2011). This ethnic division extends to religious groups and denominations as well. Hinduism and Islam are perceived as Indian religions in Guyana, hence serve to consolidate Indian ethnic identity and have to be considered as 'ethnic religions' (van der Veer and Vertovec 1991). Christianity, on the other hand, is predominantly associated with 'African,' 'Mixed,' and 'Portuguese' groups. According to the latest published national census, $64 \%$ of the Guyanese population is Christian, $24.8 \%$ is Hindu, and 6.8\% is Muslim (Bureau of Statistics 2012). In such a diverse religious context, struggles for authority and community leadership take place and result in contestations as well as the hierarchization of religious beliefs and practices. For example, the history and development of Hinduism in Guyana has been influenced by syncretistic exchange with Christianity and Islam but also by inferiorization processes, proselytization, and stigmatization (Younger 2009).

Religious and ethnic identities are related and cannot be considered distinct in this multi-religious and multi-ethnic society. Although the ethnic division in congregations and along denominational lines has diminished over time, it has not totally been erased. 'Why is it that the 11 Sunday morning service is the most [racially] segregated hour in Guyana?', asked a social commentator in a local newspaper in December 2014, indicating and criticizing that congregations are usually dominated by a particular ethnic group (Pantlitz 2014). While Hindu and Muslim congregations consist almost exclusively of Indians, Christian denominations are more diverse. In the Elim Pentecostal and Wesleyan churches that I visited near and in Georgetown, the congregations consisted of mostly Africans and 
Indians. Officiating priests were both African and Indian, although predominantly African. Preferences for specific Christian denominations are prevalent among the different ethnic groups today as they have been in the past, although these preferences change over time. For instance, Africans used to be predominantly Anglican or Methodist before the rise of Pentecostalism, while the majority of Potogee were Roman Catholic. Guyanese Indians predominantly converted to the Presbyterian denomination as a result of the Canadian Presbyterian Mission's work in then British Guiana. At present, according to Guyanese scholars to whom I talked in person, 'most' Indian Christians are Catholic and 'some' are Pentecostal (Daniel and Ram, personal interviews). These observations are in line with my own impressions gathered in the various religious institutions as well as through my involvement in the local communities since 2011. For example, in my Indian host family, three of my host mother's nine siblings have converted from Hinduism to Christianity, two of them joining the Catholic Church and one of them the Seventh Day Adventist Church. Interestingly, in conversation about the various religious traditions, my Hindu informants highlighted that there are similarities between Hinduism and Catholicism. They frequently commented that Catholics would do 'the same', for example they would also worship 'idols' - pictures and statues of Jesus. ${ }^{9}$ These practices, which reminded them of the veneration of Hindu deities, continue to be degraded as 'idol worship' by proselytizing Christian groups. The Seventh Day Adventists have started to attract Hindu converts in rural regions of the country, for example the Indian-dominated eastern region of Berbice. As discussed earlier, my informants listed the holistic approach of SDA theology including its emphasis on, for example, nutrition and dietary rules as particularly adaptive to Hindu understandings of life and dharma.

More recently established churches and religious traditions such as Pentecostal churches or the Hindu Madras tradition attract members of different ethnic/religious groups. These are charismatic and ecstatic religious traditions, which are continuously growing and have to be contextualized within the general transformation of the Guyanese religious environment and national neoliberal restructuring from the 1980s. Table 5.1 demonstrates the significant increase of Pentecostals from $7.5 \%$ in 1991 to $16.9 \%$ in 2002 and 5.2\% in 2012, as well as a decline of particularly the traditional denominations such as Anglicans (from 13.8\% (1991) to 6.9\% (2002) and 22.8\% (2012)) and Roman Catholics (from 10\% (1991) to 8.1\% (2002) and 7.1\% (2012)). ${ }^{10}$ Drawing from my interviews and personal observations, this trend continues at present. The significant decline of Hindus from $35 \%$ to $24.8 \%$ between 1991 and 2012, although at first seeming to indicate high rates of conversion to Christianity, has to be relativized by taking the large scale of migration to North America into account, numbers of which were particularly high among the Guyanese Indian population during the 1990s. Ecstatic traditions are on the rise, although they often continue to be frowned upon and dismissively called 'clap-hand churches'.

The ethnic composition of congregations is influenced by residential segregation among Indians and Africans, which has been influenced by categorizations of villages and space as 'Indian' or 'African'. While traditionally the urban centres 
Table 5.1 Religious affiliations in Guyana, National Census 2012

\begin{tabular}{llc}
\hline Religious Group & & $2012(2002) \%$ \\
\hline Christian & Total & $64(57.7)$ \\
& Other Christians & $20.8(17.7)$ \\
& Pentecostal & $22.8(16.9)$ \\
& Roman Catholic & $7.1(8.1)$ \\
& Anglican & $5.2(6.9)$ \\
& Seventh Day Adventist & $5.4(5.0)$ \\
& Methodist & $1.4(1.7)$ \\
Hindu & Jehovah's Witness & $1.3(1.1)$ \\
Muslim & & $24.8(28.4)$ \\
None & & $6.8(7.2)$ \\
Other & & $3.1(4.3)$ \\
Not Stated & & $0.9(1.3)$ \\
Rastafarian & $\mathrm{n} / \mathrm{a}(0.9)$ \\
Bahai & $0.5(0.5)$ \\
\hline
\end{tabular}

Source: Bureau of Statistics 2012.

of Georgetown, New Amsterdam, and Linden were associated with the African population, the countryside was considered Indian. This segregation intensified in the course of inter-ethnic conflicts in the 1960s (Horowitz 1985; Misir 2006; Spencer 2007; Garner 2008). Generally, residential areas are defined as either African or Indian, a categorization that extends to villages today. This does not mean, however, that no Indians can be found in African villages and vice versa. The places where development organisations conduct projects are hence inevitably linked to Indian or African identities, or, in case of the interior, with the Indigenous groups.

\section{Nation-building and ethno-politicization}

Struggles for political power in Guyana were and are usually regarded as struggles for resources and ethnic domination. As religious and ethnic identities are inextricably related, these struggles extend to the various religious traditions. Particularly during national elections, inter-communal violence between Africans and Indians has been frequent. The most severe inter-ethnic tensions and instances of violence occurred in the period of 1961 to 1964 and in the aftermaths of the 1997, 2001, and 2006 elections. This development is linked to the process of ethno-politicization, due to which voting is primarily based on ethnic affiliation rather than for political objectives (Hinds 2004, 2011a; 2011b; Hyles 2014). Ethnic voting is influenced by the ascribed ethnic identity of the Indian or African party rather than the ethnic identity of individual candidates (Horowitz 1985; Bissessar and La Guerre 2013).

Ever since the independence movement in the 1950s, politicians and ethnic entrepreneurs on both sides have fostered and institutionalized anti-African or 
anti-Indian sentiments in order to maintain or challenge power (Karran 2000, 2004; Allahar 2004). Election campaigns are often echoed in local temples and churches (Alexander 2000). For example, I witnessed how some Hindu priests called for the congregations' support of the 'Indian' PPP/C during both campaigns of 2011 and 2015, highlighting the need to consolidate and to support those politicians who do not marginalize Hindu traditions. This occurred not only within their sermons, but also on social media such as Facebook, where much political campaigning takes place at present. Similarly, Christian faith was applied to vow for votes, the most popular catch-phrase in this regard suggesting that 'Jesus would vote [party X]'. Such discourse and the link between religion and politics have historical continuity and are not new phenomena in Guyana.

This background information is particularly relevant to provide a contextsensitive study, as my fieldwork for this research took place at a particular time: the campaigning for and the aftermath of the 2015 national elections. During this time, ethnic identities are more clearly accentuated and otherwise hidden processes and dynamics are revealed. Having witnessed the campaigns and national elections of 2011 and 2015, like my informants, I observed increased expressions and proclamations of ethnic identities during these periods. Commenting on this 'rise' of ethnic identities during election time, Jacob of ADRA explained in a conversation on development in Guyana: 'Election time come, suddenly their antennas are up. . . . Suddenly they know, “I'm a Indian”, “I'm a Portuguese", (personal interview). He further stated that after elections, everything goes 'back to normal'. Indeed, most Guyanese, particularly those who live in the countryside, described friendly inter-racial relations with neighbours and within their communities. Although sometimes stereotypes of other ethnic groups were brought up, in general there was a consensus that aside from the 'big' people in politics, 'we nuh living the racial' (We don't live 'the racial'; we are not racist). Yet, Premwattie, an 80-year-old Indian woman from the Guyanese countryside, anxiously explained to me a few months before the 2015 elections, like many others, that she is seriously concerned and even scared about the possibility that for the first time in 23 years - since 1992 - the 'Indian' PPP/C may lose elections. She commented that 'if Blackman rule, abee dead' (If the Black people rule, we [Indians] are dead), and ultimately added: 'me friken' (I am scared; personal interview). Similarly, Guyanese Africans proposed the alleged clannishness of Indians and the PPP/C government, who supposedly only worked towards the progress of Indian people and discriminated against other ethnic groups, particularly Africans. Until my fieldwork in 2015, the year that marked the first change of government since 1992, Guyanese Africans frequently pointed out that the government was only working towards economically developing Indians. They were fast to point out that most of the 'big houses', which are currently built all over the country, are owned by Indian families. Guyanese African political activists openly discussed the government's favouritism towards Indian companies, and one of the most common examples referred to was physical infrastructure which, according to them, was built specifically in Indian communities and villages. 
Daniel, who is a political scientist, scholar of African and African American Studies in North America, and a political activist in Guyana, where he was born and to where he frequently travels, explained such stereotypes and ethnopoliticization by highlighting that both ethnic groups 'view being out of governance as an assault on their dignity, their ethnic dignity' (personal interview). According to him and many other informants, who were hesitant to comment on these issues in formal interviews, in Guyana there exists a 'winner-take-all-system' and that so far, all governments have sought domination over the other groups instead of attempting to serve all people equally (Seecoomar 2000; Hintzen 2008; Singh and Narine 2000). Guyanese scholar Clive Thomas similarly comments that, '[f]rom slavery to the present, domination and authoritarianism have characterized state rule in Guyana' (Thomas 2000, p. 25). Political and economic domination is often justified through 'narratives of suffering' (Daniel, personal interview) that are told by the various ethnic groups. These narratives often revolve around the notion of contribution. 'Contribution' is a central concept in the Guyanese context which significantly impacts local development practices.

Discussions on which ethnic group has served or contributed 'more' to society and the Guyanese nation have become a ground for negotiations of ethnic hierarchy (Williams 1991). Guyanese frequently assert that their own ethnic group's contribution to the development of Guyana, for example in the agricultural sector, is of higher value than the contribution of 'other' groups. Based on these assumptions, each group claims superiority and their right to economic advantages and political dominance. Claims for national resources are often based on the evaluation of the groups' contributions and Guyanese often declare that they expect to receive as much as they 'deserve' for having contributed to this extent in the past and at present. They thus call for reciprocity that is not based on the equal redistribution of national resources among all ethnic groups, but a redistribution that instead rewards groups based on their 'greater' efforts at and 'higher' outcomes of giving.

Giving and taking consequently have become highly charged topics in Guyanese society and ethnic groups are defined as either 'essential' givers or takers (Williams 1991, p. 160). At present, my informants often referred to and stressed the practices of contributing, giving, and taking in informal conversations about inter-ethnic relations and social relations in general. For instance, Guyanese Africans frequently described themselves to be the 'quintessential giving' group, as their enslaved ancestors had built the plantation system through hard and manual labour (Williams 1991). They highlighted that they have suffered the longest and hardest from economic and political repressions in the colony. Indians, on the other hand, often claimed that the emancipated Africans had almost ruined the colony in the 19th century because of their refusal to work regularly and their demands for high(er) wages. From their perspective, it "was the labor of the East Indian immigrants that not only brought it back from the brink of ruin but also made possible the expansion of the plantation system and economy' (Williams 1991, p. 163).

In this tense ethnic context, it is not surprising that my informants found it more necessary to classify the various development and humanitarian organisations and 
their work on the basis of ethnic identities than to define them as either religious or secular. For development work and policy-making, this background illustrates that local actors do not consider organisations as neutral. Ethnic identification extends not only to political parties, groups of people, villages, or religions, but also to development and humanitarian organisations, NGOs and FBOs. Although organisations such as the Guyana Red Cross Society do not define themselves as faith-based, Guyanese commonly identify it as Christian, pointing out that they use a cross as their symbol. This circumstance necessarily influences the organisations' work, outreach, and impact. This leads to the question: how does this specific context influence local concepts and practices of development? How does the notion of contribution influence development work on the ground?

\section{Development and leadership}

What is understood as development is transformed over time and may also vary according to different socio-cultural contexts. Today's understanding of development in Guyana, as much as it differs among the different social actors, has been changing in light of the local and international development paradigms. International development discourse has been particularly influenced by European and North American discourse. In the 1950s and 1960s, the notion of development was considered in light of modernization theory and was conceptualized in terms of a basic needs strategy (see introduction in this volume). From the 1980s, neoliberal thinking dominated development discourse, according to which the role and influence of local governments had to be reduced or at least diminished in order to enhance the development process. Local governments increasingly came to be regarded as incapable of 'developing' due to (alleged) incompetence and high levels of corruption. In this period, European development discourse shifted from a focus on responsibility to efficiency, leading, in practice, to a move away from providing for the basic needs of the 'less developed', for example through giving material goods, to providing knowledge and advice in order to 'help people to help themselves' (Karagiannis 2004, p. 108). Development theory and practice were consequently transformed into a 'new orthodoxy in development praxis' (Stirrat and Henkel 1997, p. 67), consisting of 'a stress on participation, on empowerment, on bottom-up as opposed to top-down approaches to development, a stress on process rather than blueprint projects, on indigenous rather than on expert knowledge' (Stirrat and Henkel 1997, p. 67). Various levels and kinds of NGOs developed that started to create networks and co-operations. Commonly today international NGOs collaborate with local NGOs, who are often said to be more 'efficient' in grassroots development practice due to their knowledge and involvement in the communities. Such co-operations are usually framed in terms of 'partnership', a term that often leads to the blinding out of the hierarchical relationships of the different NGOs involved, a point that I return to later (Stirrat and Henkel 1997, p. 75).

Guyanese development discourse has been influenced by these international ideas and concepts. However, the highly specific contexts of post-independent 


\section{8}

Sinah Theres Kloß

Guyana have also affected what has been defined as 'development'. Particularly noteworthy were the 1980s, a period in which the country experienced a severe economic crisis and increased poverty under the authoritarian rule of Forbes Burnham. In an attempt to make Guyana an autarkic nation and the food basket of the Caribbean, the socialist Burnham government applied a national development plan that focussed on feeding, clothing, and housing the nation (Garner 2008). During my fieldwork - almost 30 years later - I was frequently told that during the early 1980s, locally also referred to as the 'Burnham Years', Guyana 'ranked' only slightly higher than Haiti in terms of development. Negative statements such as 'the World Bank had Guyana rated just above Haiti' (Jacob, personal interview) are intricate to narratives of national history and narratives of suffering. With the liberalization of the economy towards the end of the 1980s and the implementation of the Economic Recovery Programme under Desmond Hoyte in 1988, Guyanese development discourse was influenced by the international, increasingly neoliberal development discourse. Today, government officials and employees of development organisations often explain the process of development in terms of (what they describe to be) World Bank categorizations. Jacob of ADRA, for example, highlighted the transition of Guyana from 'less developed' to 'more developed' in our conversation on Seventh Day Adventist development work. Working-class Guyanese frequently explained and elaborated that Guyana is a 'Third World country' while nations such as the USA, according to them, are 'developed' countries.

In conversation with volunteers and employees of ADRA and SAF, they usually referred to development in terms of providing both material goods and advice to help the 'poor', thus combining basic needs and self-help approaches, as discussed earlier. They often named the lack of leadership and good governance as the main criteria that hinder the development of Guyana. According to them, Guyanese politicians have lost the population's faith and trust due to corruption, favouritism, and immoral behaviour. They explained that the state does not work for the people, but instead acts like a company that only seeks to maximize profit for itself. Terms like 'politricks' - a blend of politics and tricks - have become prominent in public discourse, indicating the level of how politics are considered to be characterized by self-interest and corruption. Good governance is hence regarded as a key factor in developing the nation and society, and representatives of both ADRA and SAF addressed the lack of 'good' leaders. For example, Vijay of SAF, who has migrated to the USA and frequently returns to Guyana to conduct charitable events and 'spiritual development' programmes (such as music classes and theatre workshops), explained that the 'mindset' of the Guyanese in Guyana 'needs to change', and that for this 'they need the leadership'. Opposing Guyanese in Guyana to Guyanese who live elsewhere, particularly in the 'developed' North, he indicated that 'leadership' is brought along by Guyanese-American volunteers, including himself. He commented that 'our [Guyanese-American] mentality is go-go-go, and their mentality is like, I go when I want', implying a lack of discipline, motivation, or ideas. He further highlighted that 'you physically have to be here' to achieve something, as 'you [may] get the volunteers, but you 
have to lead'. He finally added that most Guyanese in Guyana 'don't know how to execute' (personal interview). This conversation was framed by him telling his wife to show me the two-week schedule they had prepared for their current trip to the Guyanese countryside from New York - a truly impressive and neat list of meetings, events, and organisational tasks prepared on two sheets of paper. They further emphasized that they were 'giving' and 'sacrificing' their annual leave from their jobs in the USA to be even busier and loaded with work on their so-called holiday. A similar statement was taken as a quote for the foundation's Facebook profile, highlighting the relevance of the notion of giving, to which I will return later: 'The greatest gift you can give someone is your time, because when you are giving someone your time you are giving them a portion of your life that you will never get back' (Facebook, September 2016). The discourse on (the lack of) good governance extends to other organisations and lay people. In particular, religious organisations highlighted the need for better leadership in order to 'move forward'. Representatives and leaders of the Catholic Church in Guyana, for instance, similarly addressed the lack of good leaders, stressing their programmes for stewardship, as stewardship 'has a development side to it' (interview with a representative of the Roman Catholic Church of Guyana). ${ }^{11}$

Jacob and Vijay's discussion on good leadership and governance exemplifies how they consider themselves as providers of advice and better knowledge due to their involvement in international organisations and for having moved and having been exposed to work processes in a 'developed' country. They thus claim to have the know-how to develop, although this does not prevent them from engaging in 'partnerships' with local actors. Development, in this context, is thus viewed as only possible with 'Western' influence, know-how, advice, and funding, which highlights an influence of modernization theory. My informants either affirmed this perception and evaluated this influence as positive, as enabling 'modernity', or they rejected this idea and regarded this influence as negative, for example people who conceive development as a kind of 'Western' imposition and mode of subordination. Such discussion on 'good governance' and 'good leadership' is intricately linked to the discourse of efficiency and the 'knowing how to do better' (Karagiannis 2004, p. 110).

In order to provide knowledge and to contribute to development and nationbuilding, a person has to 'give' something - in the case of SAF this is understood to include various aspects, for example the giving of a person's time. As this discourse on gifts and contributions is prominent in Guyanese conversations on development, this analysis has to consider local notions of gift-giving.

\section{Doing and giving development}

The Guyanese discourse of development is linked to the notions of giving, taking, and receiving, and hence to the concept of gift exchange. This holds true when looking at the significance of contributions in the local construction of ethnic groups and for the discourse on nation-building, as discussed earlier. Practices of contributing are ultimately related to reciprocity and hierarchical relations that 


\section{0}

Sinah Theres Kloß

develop or transform through practices of giving or sharing. The relevance of gift exchange theory in development discourse and practice must not be considered as an exception for the Guyanese context. Commonly, gift exchange and reciprocity are linked to pre-modern or archaic societies. However, the differentiation of reciprocal gifts and contractual commodities of market exchange has to be considered as artificial (Widlok 2017). As discussed by Frank Adloff and Steffen Mau, ' $[\mathrm{m}]$ odern social relationships seem too complex, too strongly institutionally or systemically mediated to be capable of being traced back to arrangements of reciprocity' (Adloff and Mau 2006, p. 95). However, reciprocal relationships exist in all kinds of social interaction, not only within families and other close relationships, but also macro-processes organized by states or the market (Adloff and Mau 2006). Similarly, R. Kowalski argues that in the context of International Development Aid, concepts of exchange are based on market approaches that stress the need to formalize exchange. As International Development Aid is 'embedded in the modernity project', Kowalski states, 'donors both act from a position in which The Gift system is downplayed and which seeks to annihilate its existence whilst illogically being entirely dependent upon relationships at both state and personal levels that only the system of The Gift can provide' (Kowalski 2011, p. 196). Relationships between givers and receivers of development funding are usually presented as partnerships 'between organisations bringing different but equal resources and skills' (Stirrat and Henkel 1997, p. 75) and are masked by chains of intermediaries that conceal the unequal relationship of giver and receiver.

According to classical gift exchange theory, the giver or provider of a gift, alms, or aid, claims a higher status in relation to the receiver. Although not always directly pronounced, negotiations of hierarchy are always intricate in such practices and (re-)distributions. By being able to give and provide, a person claims and creates the status of giver and donor, generates symbolic capital, high social status, and prestige. The giver's status rises in relation to the receiver of the gift, who has to return the gift to recreate his or her status. According to Marcel Mauss, the '[f]ailure to give or receive, like failure to make return gifts, means a loss of dignity' (Marcel 1966, p. 41). Only when the receiver reciprocates the gift is his or her status reconstituted. Displaying the capacity to provide, initiate, or facilitate the process of development, social actors may point out others who are needier, may challenge their developed status, and may enhance their own status in society. It has been widely discussed among anthropologists whether 'pure' or 'free' gifts exist or whether gifts can ever be disinterested. For example, Jonathan Parry claims that the Indian/Hindu concept of the gift is not based on the expectation that a gift has to be returned and that Indian gifts are non-reciprocal (Parry 1986). Similarly, Narmala Halstead describes how in the Guyanese context, Indians 'exchange gifts as part of an ideology of giving without receiving' (Halstead 2011, p. 278) and give to express their love, duty, and devotion. However, as I have discussed elsewhere, although my informants indeed confirmed this ideal of altruistic giving, numerous times, they also expressed that they would certainly 'hope for' something in return, and that giving will benefit them by receiving blessings, higher status, and/or good karma in return (Kloß 2016). 
In the context of development practice, beneficiaries and receivers of development work are usually perceived as a 'generalized impoverished other' (Stirrat and Henkel 1997, p. 72) by those who provide and fund the development activities and programmes. In this context, being labelled as receivers of charity or beneficiaries of development work, one's social status is inevitably lowered in relation to the providers and facilitators. This view is especially pertinent in the multi-ethnic context of Guyana. During my fieldwork, when enquiring for instance whether an informant had ever gone to a charitable distribution, this was usually immediately negated and it was stressed that 'only the poor does go' (Kloß 2017). Similarly, the director of the Guyana Red Cross Society described several instances and operations during its disaster relief programme in which villages, labelled by Red Cross volunteers as severely affected by flooding, rejected their support by pointing out that other village communities were in much greater need of support. The director described that some of the village councils had explained: 'We can manage, but there is a different group further down [the river], can you go to them?' (personal interview). She explained and concluded that nobody wants to be marked as 'receiving'.

While SAF and ADRA do not pronounce significant differences in their projects and objectives, there is a difference in who should be the receivers and beneficiaries of their work. SAF only focusses its work among the rural communities along the coast, the stretch of the country where $90 \%$ of the Guyanese population lives. Although they did not confirm this aspect, from personal observations it has to be remarked that the villages in which they conduct their projects are usually identified with the Guyanese Indian population. In addition to this, the organisation's name 'Save Abee' is Guyanese Creole and translates to 'Save Us'. The term 'abee' is connoted with rural Indo-Guyanese Creole at present, and hence with the 'Indian' ethnic group. Contrary to this, ADRA includes the Amerindian communities in the so-called interior (Guyanese hinterland) into their work, communities that are also heavily influenced by SDA missionary activities.

These aspects reflect the organisations' concepts as to who needs but also who deserves development and who is considered poor from their perspectives. As SAF's volunteers are usually 'overseas Guyanese' or members of the local upper class, they consider all rural communities along the coast and in the interior as poor and needy, but have to prioritize their work on specific communities. I suggest that SAF may also consider Amerindians and other rural groups as poor, but may prioritize their work especially among the Indian group due to restricted time and funding, and to empower the Indian/Hindu group, which they perceive to have been inferiorized and maltreated. They are, without exception, members of the Indian ethnic group, thus are perceived as 'Indian' or even 'Hindu' by most Guyanese. On the other hand, ADRA employees usually live in Guyana and consider Indigenous people as needier than 'other' Guyanese, of which they are a part, and therefore include them in demonstrating good and inclusive leadership and possibly also to support SDA missionary 'outreach' programmes. My informants consider ADRA as Christian, and thus in moments of ethnic tension members of opposing groups will necessarily label their work as 'religious' and 'proselytizing.' 


\section{Sinah Theres Kloß}

\section{Challenging power structures}

In this context acts of giving and 'doing development' become missions to challenge local power structures. Both organisations compete for status and negotiate power relations in the Guyanese community through practices of giving, taking, or rejecting. This competition not only reflects individual endeavours, but implies and extends to status negotiations of specific ethno-religious groups, who development organisations (are said to) represent. The work of specific development organisations hence influences ethnic group and identity formation in present-day Guyana. For example, Guyanese Hindus regularly link the practice of conducting charitable distributions - as part of their combined development-charity-humanitarian approach - to Christian churches and pejoratively comment on these practices. They describe that Christian missions, now and in the past, have actively tried to convert Hindus to Christianity by such distributions, including organisations such as the Red Cross. ${ }^{12}$ Indeed, Guyanese Hindus have converted to Christianity in order to achieve upward social mobility in the past. Being Christian was regarded as a prerequisite to claiming and creating 'respectability' in the predominantly Christian society in which Hinduism was denoted as 'idol worship' and 'backward' ${ }^{13}$ Those Indians who converted to Christianity were frequently dismissed as 'belly-Christians' within the Hindu and Muslim communities, meaning that they were regarded to have converted only for food, schooling, and the comfort of specific material goods (Jayawardena 1966; Kloß 2017). Even today and although, in general, numbers of inter-faith conversion are not exceedingly high, the 'threat of conversion' is a common topic in conversations and Hindu sermons. Missionary work should not be considered as a historical practice, but today the number of missionaries is the highest in historical comparison, US Protestant missions forming the dominant force (Hearn 2002). This force is visible in contemporary Guyana, for example at popular 'expat' meeting spots in the capital, where (White) Christian groups often meet. Vijay, who is a volunteer at SAF and the Nirvana Humanitarian Society, thus commented during the medical outreach programme in August 2015 that Christian organisations are still very active in proselytization. According to him, they offer Hindus material goods such as clothing or educational services such as sewing classes. He commented that Christians are 'converting them wholesale' (personal interview), indicating not only the large amounts of people they (seek to) convert, but furthermore the material and economic implications of this process.

Similarly, Prakash, whom I introduced at the beginning of this article, explained his motivation for his voluntary work with SAF as a way to contest Christian mission work and dominance. Similar to many Hindus in Guyana, he emphasized Christian mission work as a direct threat to and assault on local Hindu traditions. He described:

I cant stand to see my people living in poverty when i know i can do something to help them. Christian missionaries go to guyana and tell the people them if they become christians that their life will become better and how they will get food and clothing from them . . . and i tell $u$ this alot of people give in to it ... i cant stop that from happing but $\mathrm{i}$ can aid my people them to become 
stronger, believe in our way of life. . . . Hinduism may not be perfect in all aspects of life in everyones point of view. . . I have nothing against no one religions but for some one to tell my people that my religion is not real and the only way to god is through christ, that $\mathrm{i}$ have a problem with.

(Email, 3 September 2012)

In this context, Prakash regarded his volunteer work as a possibility not only to support those people whom he defined as poor and needy, but furthermore to demonstrate the capacity of Hindus to organize charitable and developmental work.

Gift exchange consists of three stages - the acts of giving, accepting, and returning a gift. The non-acceptance of a gift, of support, or of specific services may thus be regarded as transforming and challenging social hierarchy. The rejecting person denies lower status and hence directly or indirectly challenges the giver. When rejecting a gift, a person or group has the capacity to counteract the label of 'taker' and to reject a lower status position. By not only rejecting Christian charitable gifts, hence denying a lower status of Hindus, Prakash implemented his distributions as a practice of resistance - and development - that enabled him and Hindus in general to take on the societal position of giver and to (re)define who is 'poor' and 'needy'. He consequently dismantled the (colonial) idea that Hinduism is an obstacle to development, highlighting that Hinduism indeed is no source of under-development and does not lack social concern (Renders 2002; Nadkarni 2007).

Asking himself, "why is it that there are only Christian missionaries that travel the worlds to convert to Christianity? Why [do] they target third world countries? Why do they feed off the poor and uneducated to their standards? What makes them think that their way of life is the only way of life?' he pronounced his general resentment towards practices of cultural imposition and conversion. Emphasizing that SAF's intentions are not to convert people to Hinduism by offering development support and humanitarian services, he also pointed out his and the foundation's greater morality in relation to Christian organisations. Although he admitted that among his intentions is the warding off of Hindu conversion to Christianity, he claimed to be acting based on more genuine and humanitarian principles compared to Christians, claiming a higher status of Hinduism at the inter-religious level and thus contesting Guyanese socio-religious hierarchy and the dominance of Christian churches. In a similar way, ADRA challenges the socio-religious hierarchy; it challenges the more established Christian churches - Anglicans, Methodists, Catholics - and their positioning in the local hierarchy. Thus, both organisations claim to be, and create, better leaders, who are 'more moral' and 'more spiritual'. These claims accentuate the perceived relevance of morality and spirituality for good leadership and governance, hence for holistic development.

\section{Conclusion}

Holistic development is a concept used to contest hierarchy in Guyana. It supports claims for more efficient development, to achieve better living conditions on the 


\section{Sinah Theres Kloß}

one hand, but on the other hand intricately serves as a means to claim or maintain powerful positions in social relations as well as local socio-religious hierarchies. To most of my informants in Guyana, holistic development consists of both material and spiritual dimensions, which have to be combined in order to achieve sustainability. Disseminating an alternative notion of development, the studied organisations may be regarded as development entrepreneurs, as discussed in the introduction of this volume (Koehrsen and Heuser 2019). Claims of conducting holistic and hence more effective development enable and support specific development organisations' acquisition of funding and status. Such claims imply concepts of 'good' or 'better' ways of doing development. Furthermore, social actors, ethnic groups, and development organisations claim and negotiate status on the basis of claiming societal positions of giver, or of being a 'better' (more moral) giver. Giving as a social act between people requires a taking, receiving, or rejecting; hence the capacity to provide for oneself and to define others as needier contests established power structures in society. Development organisations must hence take on a view of development that does not mask the continuing and intricate relations of power. They have to acknowledge that although they may claim a secular identity and a multi-religious, multi-ethnic approach, local actors and 'beneficiaries' may have different perspectives on how the identity and work of an organisation is constituted, focussing for instance more on the aspects of where and with whom an organisation works. As the relation between power dynamics and faith-based development work is under-researched at present, this seems to be a promising topic for further research, particularly in multi-religious societies and inter-religious co-operations.

\section{Notes}

1 The author would like to thank the members of the fellow group 'Religion and Development in the Global South' of the Center for Religion, Economy and Politics (University of Basel) for their helpful comments and suggestions throughout the research and writing process. For sharing their knowledge and providing support, the author also thanks many other contributors, including Rishee Thakur, David Hinds, Kemani Nehusi, members of Save Abee, Nirvana and ADRA in Guyana, Karen and Glenda Obermuller, Simmone La Rose, Priya Singh, Rollingston 'Sam' Robinson, Shanya Cordis, Oveanne Manswell Austin, Anto Bhowandin and family, the Walker family and the staff at Oasis Café, Scheherazade Khan and family, Hans Neher and family, the Outram family, Wanita Huburn, Sunil, Hugh Todd, Elizabeth Persaud, and Mark Anthony Benschop.

2 All names have been changed to ensure my informants' anonymity.

3 The mission statement is: 'Providing education and quality of life to the children of tomorrow living in poverty around the world' (capitalized in original, Save Abee Foundation, 2016, np).

4 The Seventh Day Adventist Church was formally established in 1863 in the USA.

5 Indian denotes an ethnic group in Guyana, which is socially constructed through othering processes particularly in relation to Guyanese 'Africans'.

6 Here I refer to Pierre Bourdieu's notion of capital (Bourdieu 1984/2010).

7 Mixed: 19.9\%; Amerindian: 10.5\%; Chinese: 0.2\%; Portuguese: $0.3 \%$; White: $0.1 \%$ (Bureau of Statistics 2012, p. 4). 
8 Both 'African' and 'Indian' are emic terms used among my informants.

9 In this context, my interest in Guyanese Hinduism as focus for my doctoral dissertation was explained as well: having explained that I used to be a (nominal) Catholic, most of my informants confirmed that they 'now understand' my interest in Hinduism, as both denominations are 'essentially the same'.

10 The category 'Other Christian' consists of 'Baptists, Moravians, Brethren, Methodists among others' (Benjamin 2002, p. 31). Note the double-mention of the category 'Methodist.'

11 Catholics define stewardship as a kind of leadership that exceeds the function of sharing resources, stewardship theory advocating that 'the duty of an organisation leader was to maximize long-term wealth creation to benefit society and all stakeholders' (Caldwell and Hayes 2010, p. 501).

12 As mentioned earlier, the Guyana Red Cross Society does not label itself as a Christian organisation.

13 Respectability is a specific value system in Guyana and other parts of the Anglophone Caribbean on the basis of which social status is ranked (Wilson 1969, 1973; Stoler 1989). While initially the 'mores advocated by the church, including especially monogamous marriage, [were] the ultimate referent for respectability' (Wilson 1973, p. 100), standards of respectability were adapted, challenged, and promoted especially in the post-independence era since Guyana's independence from Great Britain in 1966.

\section{References}

Adloff, F., and Mau, S., 2006. Giving Social Ties, Reciprocity in Modern Society. European Journal of Sociology/Archives Européennes de Sociologie, 47 (1), 93-123.

Alexander, V., 2000. Race and Politics in Guyana: An Historical Overview. In: K. Karran, ed. Race and Ethnicity in Guyana. Introductory Readings. Georgetown: Offerings Publication, 67-72.

Allahar, A., 2004. Ethnic Entrepreneurship and Nationalism in Trinidad: Afrocentrism and Hindutva. Social and Economic Studies, 53 (2), 117-154.

Benjamin, L., 2002. Guyana Population and Housing Census [online]. Available from: www.statisticsguyana.gov.gy/census.html.

Bissessar, A.M., and La Guerre, J.G., 2013. Trinidad and Tobago and Guyana: Race and Politics in Two Plural Societies. Lanham, MD: Lexington Books.

Bourdieu, P., 1984/2010. Distinction: A Social Critique of the Judgement of Taste. London: Routledge.

Bureau of Statistics, 2012 [online]. Available from: www.statisticsguyana.gov.gy/census. html [Accessed June 2018].

Caldwell, C., and Hayes, L.A., 2010. Leadership, Trustworthiness, and Ethical Stewardship. Journal of Business Ethics, 96 (4), 497-512.

Clarke, G., 2006. Faith Matters: Faith-Based Organisations, Civil Society and International Development. Journal of International Development, 18 (6), 835-848.

Clarke, G., 2008. Faith-Based Organizations and International Development: An Overview. In: G. Clarke and M. Jennings, eds. Development, Civil Society and Faith-Based Organizations. Bridging the Sacred and the Secular. Basingstoke, New York, NY: Palgrave Macmillan, 17-45.

Fountain, P., 2013. The Myth of Religious NGOs: Development Studies and the Return of Religion. In: G. Carbonnier, ed. International Development Policy. Religion and Development. Basingstoke: Palgrave Macmillan, 9-30. 
Freeman, D., 2012. The Pentecostal Ethic and the Spirit of Development. In: D. Freeman, ed. Pentecostalism and Development. Churches, NGOs and Social Change in Africa. Basingstoke: Palgrave Macmillan, 1-38.

Fuller, C.J., 2004. The Camphor Flame: Popular Hinduism and Society in India. Princeton, NJ: Princeton University Press.

Garner, S., 2008. Guyana, 1838-1985: Ethnicity, Class and Gender. Kingston, Jamaica: Ian Randle Publishers.

Guyanaadventists [online]. Available from: http:/guyanaadventists.org [Accessed 10 October 2016].

Hall, S., 2000. Cultural Identity and Diaspora. In: N. Mirzoeff, ed. Diaspora and Visual Culture: Representing Africans and Jews. London, New York, NY: Routledge, 21-33.

Halstead, N., 2011. Gift Practices in Guyanese East Indian Diaspora: Belonging, Loss, and Status. The Journal of Latin American and Caribbean Anthropology, 16 (2), 278-295.

Hearn, J., 2002. The 'Invisible' NGO: US Evangelical Missions in Kenya. Journal of Religion in Africa, 32 (1), 32-60.

Hinds, D., 2004. Race and Democratic Transition in Guyana: The Consequences of the 1992 Election. In: K. Karran, ed. Racial Conflict Resolution and Power Sharing in Guyana: Selected Readings. Georgetown: Offerings Publication, 86-101.

Hinds, D., 2011a. Ethno-Politics and Power Sharing in Guyana: History and Discourse. Washington, DC: New Academia Publishing.

Hinds, D., 2011b. Janet Jagan and the Politics of Ethnicity in Guyana. In: C. Barrow-Giles, ed. Women in Caribbean Politics. Kingston, Jamaica, Miami, FL: Ian Randle Publishers, 195-208.

Hintzen, P.C., 2008. The Costs of Regime Survival: Racial Mobilization, Elite Domination and Control of the State in Guyana and Trinidad. Cambridge: Cambridge University Press.

Horowitz, D.L., 1985. Ethnic Groups in Conflict. Berkeley, CA: University of California Press.

Hyles, J.R., 2014. Guiana and the Shadows of Empire: Colonial and Cultural Negotiations at the Edge of the World. Lanham, MD: Lexington Books.

Jayawardena, C., 1966. Religious Belief and Social Change: Aspects of the Development of Hinduism in British Guiana. Comparative Studies in Society and History, 8 (2), 211-240.

Johnson, W.J., 2010. Dictionary of Hinduism. New York, NY: Oxford University Press (Oxford paperback reference).

Kaieteur News, 2015a. Guyana Seventh Day Adventists to Convene Quadrennial Conference [online]. Available from: www.kaieteurnewsonline.com/2015/04/18/guyana-sev enth-day-adventists-to-convene-quadrennial-conference/ [Accessed 23 August 2016].

Kaieteur News, 2015b. Ministries Renamed to Emphasize Functions - President David Granger [online]. Available from: www.kaieteurnewsonline.com/2015/05/25/ministriesrenamed-to-emphasize-functions-president-david-granger/ [Accessed 21 March 2016].

Kaieteur News, 2016. Minister Ally Emphasises the Importance of Social Cohesion to Nation Building [online]. Available from: www.kaieteurnewsonline.com/2016/03/07/ minister-ally-emphasises-the-importance-of-social-cohesion-to-nation-building/ [Accessed 20 July 2016].

Karagiannis, N., 2004. Avoiding Responsibility. The Politics and Discourse of European Development Policy. London, Ann Arbor, MI: Pluto Press.

Karran, K., ed., 2000. Race and Ethnicity in Guyana. Introductory Readings. Georgetown: Offerings Publication. 
Karran, K., ed., 2004. Racial Conflict Resolution and Power Sharing in Guyana: Selected Readings. Georgetown: Offerings Publication.

Kloß, S.T., 2016. Fabrics of Indianness: The Exchange and Consumption of Clothing in Transnational Guyanese Hindu Communities. London, New York, NY: Palgrave Macmillan.

Kloß, S.T., 2017. Contesting "Gifts from Jesus": Conversion, Charity, and the Distribution of Used Clothing in Guyana. Social Sciences and Missions, 30 (3), 346-365.

Koehrsen, J., and Heuser, A., 2019. Beyond Established Boundaries: FBOs as Developmental Entrepreneurs. In: J. Koehrsen and A. Heuser, eds. Faith Based Organisations in Development Discourses and Practice. London: Routledge.

Kowalski, R., 2011. The Gift. Marcel Mauss and International Aid [online]. Available from: www.journaldumauss.net/. Available online at www.journaldumauss.net/IMG/ pdf/TheGift_Kolwalski.pdf [Accessed 4 July 2016].

Mauss, M., 1966. The Gift: Forms and Functions of Exchange in Archaic Societies. London: Cohen \& West.

Michaels, A., 2004. Hinduism: Past and Present. Princeton, NJ: Princeton University Press.

Misir, P., 2006. The Social Construction of Race-Ethnic Conflict in Guyana. In: P. Misir, ed. Cultural Identity and Creolization in National Unity: The Multiethnic Caribbean. Lanham, MD: University Press of America, 121-140.

Nadkarni, M.V., 2007. Does Hinduism Lack Social Concern? Economic and Political Weekly, 42 (20), 1844-1849.

Nascimento, C.A., 2000. Race and Politics in Guyana. In: K. Karran, ed. Race and Ethnicity in Guyana. Introductory Readings. Georgetown: Offerings Publication, 73-77.

Nederveen, P.J., 2010. Development Theory: Deconstructions/Reconstructions. 2nd ed. Los Angeles, CA: SAGE (Theory, Culture \& Society).

Occhipinti, L., 2015. Faith-Based Organizations and Development. In: E. Tomalin, ed. The Routledge Handbook of Religions and Global Development. London: Routledge, 331-345.

Pantlitz, A., 2014. Why Are the Churches So Racially Segregated? [online]. Available from: www.stabroeknews.com/2014/opinion/letters/12/27/churches-raciallysegregated/ [Accessed 3 June 2015].

Parry, J., 1986. The Gift, the Indian Gift and the 'Indian Gift'. Man, 21 (3), 453-473.

Premdas, R.R., 1992. Ethnic Conflict and Development: The Case of Guyana. Geneva: United Nations Research Institute for Social Development.

Ramey, S., 2011. Hindu Minorities and the Limits of Hindu Inclusiveness: Sindhi and Indo-Caribbean Hindu Communities in Atlanta. International Journal of Hindu Studies, 15 (2), 209-239.

Renders, M., 2002. An Ambiguous Adventure: Muslim Organisations and the Discourse of 'Development' in Senegal. Journal of Religion in Africa, 32 (1), 61-82.

Save Abee Foundation, 2016. Welcome to Save Abee [online]. Available from: http://savea bee.org/home/ [Accessed 23 August 2016].

Seecoomar, J., 2000. Institutional Change and Social Harmony. Undoing Our Colonial Inheritance. In: K. Karran, ed. Race and Ethnicity in Guyana. Introductory Readings. Georgetown: Offerings Publication, 42-53.

Singh, T., and Narine, D., 2000. Power Sharing in a Plural Society: The Case of Guyana. In: K. Karran, ed. Race and Ethnicity in Guyana. Introductory Readings. Georgetown: Offerings Publication, 118-140.

Spencer, S., 2007. A Dream Deferred: Guyanese Identity and the Shadow of Colonialism. 1st ed. London: Hansib. 


\section{Sinah Theres Klo $\beta$}

Stirrat, R.L., and Henkel, H., 1997. The Development Gift: The Problem of Reciprocity in the NGO World. The Annals of the American Academy of Political and Social Science, 554 (1), 66-80.

Stoler, A.L., 1989. Making Empire Respectable: The Politics of Race and Sexual Morality in 20th-Century Colonial Cultures. American Ethnologist, 16 (4), 634-660.

Thomas, C.Y., 2000. Revisiting Theories of Race and Class in the Caribbean. In: K. Karran, ed. Race and Ethnicity in Guyana. Introductory Readings. Georgetown: Offerings Publication, 14-30.

Tomalin, E., 2012. Thinking About Faith-Based Organisations in Development: Where Have We Got to and What Next? Development in Practice, 22 (5-6), 689-703.

van der Veer, P., and Vertovec, S., 1991. Brahmanism Abroad: On Caribbean Hinduism as an Ethnic Religion. Ethnology, 30 (2), 149-166.

White, E.G.H., 2010. A Call to Medical Evangelism and Health Education. Selections from the Writings of Ellen G. White. Hagerstown, MD: Review and Herald Pub. Association.

Widlok, T., 2017. Anthropology and the Economy of Sharing. Abingdon and New York, NY: Routledge.

Williams, B.F., 1991. Stains on My Name, War in My Veins. Guyana and the Politics of Cultural Struggle. Durham, NC: Duke University Press.

Wilson, P.J., 1969. Reputation and Respectability: A Suggestion for Caribbean Ethnology. Man, 4 (1), 70-84.

Wilson, P.J., 1973. Crab Antics: The Social Anthropology of English-Speaking Negro Societies of the Caribbean. New Haven, CT: Yale University Press.

Younger, P., 2009. New Homelands: Hindu Communities in Mauritius, Guyana, Trinidad, South Africa, Fiji, and East Africa. New York, NY, Oxford: Oxford University Press. 


\title{
6 Contextualized development in post-genocide Rwanda
}

\author{
Exploring the roles of Christian \\ churches in development and \\ reconciliation
}

\author{
Christine Schliesser ${ }^{1}$
}

\section{Introduction}

In 1994, violence exploded in the small country of Rwanda in Central Africa. Within 100 days, up to 1,000,000 children, women and men were slaughtered before the eyes of a world that silently stood by (Dallaire 2004). ${ }^{2}$ Most of the victims were members of the Tutsi-minority (accounting for about $15 \%$ of the Rwandan population), yet countless moderate Hutu that refused to participate in the bloodshed were murdered as well. For the survivors, the prospects were bleak. The country had been turned into debris and ashes. Even before the civil war, starting in 1990 and culminating in the devastating genocide of 1994, Rwanda had been a country of "Low Human Development" according to the Human Development Index (HDI). After the end of the genocide, the country's Human Development Index Value (HDIV) had dropped from 0.291 in 1980 to 0.238 in 1990 (cf. United Nations Development Programme).

Yet recent years have witnessed a remarkable change. Rwanda's HDI value has steadily increased to 0.524 in 2018. Credit Suisse, one of Switzerland's most renowned banks, has recently praised Rwanda's "economic miracle" and "irrepressible entrepreneurial spirit" (Amman 2015, p. 31). Indeed, banks and business around the world have started to pay attention to Rwanda. As "foreign investors are coming in droves, net direct investments have increased more than 20 -fold" (Amman 2015, p. 40). At the same time, concerns regarding a political climate that tends to stifle basic human rights such as freedom of opinion, of press and of political opposition continue to be voiced (Thomson 2015; Bouka 2018). ${ }^{3}$

This chapter is an attempt to follow Rwanda's quest for political stability and development by looking at some of the factors that are transforming a country devastated by bloody conflict into a thriving community and expanding economic force. Of the many factors that influence Rwanda's development in key areas such as education, infrastructure and the health system, we will examine two in particular, the role of Rwanda's religious actors, especially Christian churches, and the role of the Rwandan government's emphasis on reconciliation. With over $90 \%$ of Rwanda's population adhering to the Christian faith, the questions guiding my research include: What roles do Christian churches play in reconciliation and 
development efforts? How is the relationship between reconciliation and development being perceived? And are there any differences between the developmental and conflict resolution activities undertaken by these religious actors and those exerted by secular actors such as the government?

After an introduction into the specific context of post-genocide Rwanda, three main parts will serve to explore the questions above. The first two parts are devoted to the roles of Christian churches, in the context of development as well as in the context of conflict resolution. In order to include different voices from the Christian faith, I will look at Rwanda's Anglican, Presbyterian and Pentecostal churches. A third part then seeks to compare and contrast the role of religious actors in development and reconciliation with the role of the Rwandan government. In the end, we will see a contextualized understanding of development emerge that links development inextricably to conflict resolution and reconciliation. In the context of post-genocide Rwanda, developmental endeavours cannot be viewed separately to efforts for reconciliation. Hence, Christian churches as specific types of FBOs in Rwanda have to adapt to the national field of development discourses where reconciliation is the key issue.

In my methodology, I make use of a combination of approaches. A hermeneutical perspective aimed at the analysis of scholarly literature is utilized together with a modest empirical investigation based on material available online as well as the evaluation of qualitative semi-structured interviews conducted with central actors within Rwanda's development and reconciliation context in February 2016.

\section{The context: country, culture, genocide}

In 1994, this small country - which is about half the size of Switzerland - leapt into the consciousness of the world community by being ravaged by one of the fastest and shortest genocides in human history. This eruption of violence that cost about 1,000,000 people their lives was preceded by decades of violent hatred between the Hutu and the Tutsi. Here, it is pertinent that Hutu ( $84 \%$ of the population), Tutsi (15\%) and Twa (a minority of about $1 \%$ ) are not considered conventional ethnic descriptions. Rather, they refer to social groups sharing one and the same language and culture. The social ascriptions Tutsi, Hutu and Twa depend on wealth and occupation. Whoever had more than ten heads of cattle was considered a livestock farmer and thus a Tutsi. Whoever had less was a tiller and Hutu. It was the colonial powers - first Germany, then Belgium after the First World War - that encouraged the rivalry among these groups by their strategies of divide et impera. Religious sociologist Richard Friedli thus rightly speaks of a "historical responsibility of Europe" (Friedli 2000, pp. 138-139) with regards to Africa's ethno-political conflicts, including Rwanda. After Rwanda's independence in 1962, these rivalries intensified, resulting in massacres with hundreds of thousands killed.

At the time of the genocide in 1994, Rwanda was one of Africa's most "Christian" countries. Still today, over $90 \%$ claim adherence to the Christian faith (National Institute of Statistics of Rwanda 2014). Even though the Christian 
churches, in particular the Roman Catholic church, have lost a lot of credibility due the complicity of some of their clergy and members in the genocide, the Christian faith is still deeply ingrained in Rwanda's sense of self-identity. This accords for the fact that the Christian churches hold a paramount position as significant players in Rwanda's civil society. Rwanda thus presents a social and religious makeup quite different from the Western secularized countries with its strict separations between public/secular and private/religious spheres.

Being among the smallest African countries with about 12 million inhabitants, Rwanda is at the same time Africa's most densely populated country. It is therefore impossible for perpetrators and victims to permanently avoid each other. Here, we face a situation entirely different from, for instance, Germany and its former European enemies after World War II with Europe's clear-cut borders. After they are released from prison, perpetrators usually go back to their families and their home villages which are not uncommonly also the place of their atrocities and the home of the survivors. Furthermore, it is important to keep in mind that for many people, everyday life in Rwanda cannot be managed by the individual. Harvest, building houses, even daily tasks such as fetching water depend on the interaction and mutual support of family and village structures.

The Rwandan genocide distinguishes itself not only by preventability, its systematic preparation, its brevity and its intensity, but also by its cruelty. Most people were killed with machetes, which were used to cut the victims into pieces, men, women, children. Due to the violent sexual excesses in the Rwandan genocide, sexual violence and mutilation has since become considered and punishable as a genocidal crime (cf. the so-called "Akayesu ruling" of 1998). Another characteristic of this genocide is the fact that many of the victims and the perpetrators knew each other, they were friends, or even family. While any genocide is directed at the total annihilation of the opponent, in Rwanda, it was directed in particular against the next generation, the children. A UNICEF study of 1998 found that $96 \%$ of children had been affected actively or passively by the massacres (Gupta 1998). $84 \%$ of the children, who had lost their parents, siblings or other relatives, had been direct witnesses of their brutal murder. $27 \%$ had witnessed rapes and $22 \%$ of the children managed to save their lives by hiding underneath human corpses. These children, having survived the slaughter, are now the generation that is faced with the task to rebuild their country.

According to the most recent UN Income Index of 2018 (cf. United Nations Development Programme 2018), Rwanda is considered a poor country, ranking 158 of 189 . Yet since 2005 , Rwanda's GDP per capita has steadily and consistently increased, as has its HDI value. Indeed, recent years have seen a remarkable economic progress. I have already mentioned Credit Suisse's enthusiastic praise of Rwanda's current economic miracle (Amman 2015). Indeed, banks and business around the world have started to pay attention to Rwanda; Rwanda's capital Kigali has become a buzz centre for commerce, banks and business. The economy has grown by $7 \%$ to $8 \%$ each year over the past decade, benefitting large segments of the population. Compared to 20 years ago, life expectancy has doubled to 67 years, child mortality has dropped by $80 \%$ and $98 \%$ of children, including 
girls, attend primary school. There is a nationwide health insurance plan, a quite remarkable achievement for a developing country. In the World Bank's "ease of doing business" index, Rwanda ranks 46th, thereby outperforming Italy, Greece and Luxembourg (Amman 2015, p. 34). With these comments on the context serving as a background to the following deliberations, we will now take a closer look at the roles of Rwanda's religious actors in the country's developmental process.

\section{"Holistic development"4: Rwandan churches and development}

The religio-scape of Rwanda shows remarkable differences between pre- and post-genocide times. ${ }^{5}$ The most significant difference is a sharp decline of membership within the Catholic church, which dropped from $65 \%$ in 1990 to $44 \%$ postgenocide. In contrast to this, there is a noticeable increase within the Protestant denominations that almost doubled in membership and are now at 38\%. The membership of the Church of the Seventh-Day Advents increased after the genocide, progressing from $8 \%$ to $12 \%$ (National Institute of Statistics of Rwanda 2014, p. xv). With over $90 \%$ of the population adhering to the Christian faith, the Christian churches function as significant actors in Rwanda's civil society. As such, they assume a crucial role in all processes affecting Rwandan society, including development and reconciliation.

Below, I explore the concepts of development as displayed by three different FBOs in Rwanda, the Presbyterian Church, the Anglican Church and the Pentecostal Church. In the following, I employ the term FBO according to Susan Dicklitch and Heather Rice's proposal that "FBNs [Faith-based NGOs] $]^{6}$ can be defined as non-state actors that have a central religious or faith core to their philosophy, membership, or programmatic approach, although they are not simply missionaries" (p. 662). As such, churches can be viewed as a specific kind of FBO. Part of this specificity surfaces when regarding the issue of evangelism or proselytization. As Heist and Cnaan note, FBOs are often suspected of using development as a means for converting locals and adding new members (Heist and Cnaan 2016, p. 11). Many Christian churches, however, view evangelization as part of their DNA. Development is thus not employed as a disguise for evangelization. Rather, a concern for development often arises from their understanding of Christian responsibility and love of their neighbour. ${ }^{7}$ Regarding the issue of FBOs and proselytization, Heist and Cnaan also point to the fact that not only FBOs, but "all organizations aim to transform the way people in developing countries think and operate" (Heist and Cnaan 2016, p. 12). Nevertheless, they add that the majority of FBOs focus on providing developmental services rather than on proselytization. A comprehensive overview of the academic literature on FBOs has recently been presented by Ware et al. (2016) and Heist and Cnaan (2016). Neither of them, however, discuss local churches within developing countries and their role in development, which is the focus of this chapter. ${ }^{8}$ In a first step, we will look at similarities and differences between these three different Christian players with regards to their understanding of development. Special attention will be 
given to the way they relate to developmental norms as presented by the Sustainable Development Goals (SDGs).

We will begin by taking a closer look at the developmental endeavours of the Église presbytérienne au Rwanda (EPR). The EPR's beginnings date back to 1907, when German missionaries from the Bethel Mission came to Rwanda. In 1959, the church became independent and took on its current name. Today, the EPR has about 300,000 members. With 50,000 new members in the past five years alone, the EPR belongs to the fastest-growing Christian denominations in Rwanda. The steady increase in membership is not least due to its current focus on evangelism and church growth. The EPR's vision is to "build a strong church whose Christians are spiritually mature, able to testify God's kingdom in the world and whose social environment is fully bloomed" (Église presbytérienne au Rwanda (EPR)). In order to achieve this vision, it views itself under a twofold mission, evangelization and development: "firstly to evangelize by proclaiming the love and salvation offered by God through his son Jesus Christ . . . and secondly to manifest the love of God through the concrete actions of human and social development" (Église presbytérienne au Rwanda (EPR)).

To the current President of the EPR, Pascal Bataringaya, the mission of "social development" is church oriented and based on the development of families. "We can develop the families. For if the families can develop, we can develop the church". ${ }^{9}$ This is elaborated in more detail by Odile Nagahire, the director of development of EPR's Gitarama Presbytery under the perspective of "holistic development". "The developmental concept of the Presbyterian Church in Rwanda which stipulates that the process of Development has to be holistic in terms of addressing all dimensions of life (spiritual, social, economic, intellectual, cultural and ecological) at all levels of the church (individuals, families, grassroots churches, chapels, parishes, presbyteries and the national level of EPR) in a bottom-up approach (from the grassroots to the top level) as it is believed that if individuals and families are strong, the church will also be strong" (Église presbytérienne au Rwanda (EPR) 2016).

With the long-term goal of developing the church in mind, the Presbyterian Church engages in a variety of developmental projects that take up different developmental norms put forward by the SDGs as the following examples show. ${ }^{10}$ SDG 3 ("Good health and well-being") and SDG 4 ("Quality education") are taken up by the church's engagement in a number of co-operations with both other religious as well as secular partners. In a specific kind of public - private partnership with the Rwandan state, the Presbyterian Church manages more than 100 schools, 2 hospitals and 7 health centres. While the church is responsible for the buildings, the infrastructure and materials necessary, the government pays for the teachers and the medical staff. Furthermore, in co-operation with an international religious NGO, the Presbyterian Church has built a care centre for more than 100 homeless boys in Kigali, providing food, care and education. This can be linked to SDG 1 ("No poverty"), SDG 2 ("Zero hunger") in addition to SDG 3 and 4. Through their training of women to become pastors, the Presbyterian Church promotes gender equality (SDG 5) in a predominantly patriarchal culture as they also teach 
care of the environment as God's creation (SDG 6 "Clean water and sanitation" and SDG 13 "Climate action"). The EPR, we can sum up, is engaged in a wide variety of developmental efforts that link to different SDGs. Their faith dimension is clearly visible in their concept of holistic development, which is characterized by an ecclesiological dimension. The ultimate goal of developmental endeavours is thus the development of the church of Jesus Christ.

Next to the EPR, we will take a closer look at the Anglican Church's understanding of development. With about 1 million members, the Anglican Church has become a significant player in Rwanda's civil society. The Anglican Church has its roots in the former Rwanda Mission that established is first station in 1925 (cf. Anglican Communion Rwanda). The Anglican Church - as well as the EPR - exemplifies a specific type of FBO: While it is an FBO in its own right, it is at the same time part of a larger international network of churches and mission organisations, the German-based FBO United Evangelical Mission (UEM). ${ }^{11}$ As a member of the larger FBO body UEM, the EPR and the Anglican Church thus profit from personnel exchanges and financial aid through UEM partner churches. Heist and Cnaan point to this specificity as a strength unique to FBOs. "[M]any faith-based international NGOs have the advantage of local congregations that they can mobilize in their development and welfare services. Having supporting allies on the ground is a strategic advantage that many secular NGOs lack" (Heist and Cnaan 2016, p. 7).

Developmental endeavours by the Anglican Church have been channelled in the Rural Development Interdiocesan Service (RDIS) with its vision of " "a holy soul in a healthy body' with a focus on the person as a whole" (Kabango 2003). The aim is, according to RDIS's former leader John Wesley Kabango, ${ }^{12}$ to work for the "development of the poorest of the poor" (Kabango 2003) through projects that aim at building livelihoods in poor areas, through occupational training in areas such as animal husbandry, food production, micro-enterprise development, fisheries, beekeeping and tree nurseries. Similar to the EPR, development for the Anglican Church is set in a church context: "It is our conviction that the church holds the key to the real development of life in Rwanda and that God is longing to use its ministry to transform the physical, spiritual and social lives of ordinary people and the environment in which they live" (Kabango 2003). By referring to the physical, spiritual and social dimensions, the Anglican Church displays a holistic understanding of development. Yet the Anglican Church clearly distinguishes "Christian development" from other kinds of development: "Christian development does not mean organizations, buildings or projects, but building up mature Christians and teaching them skills to improve the quality of their lives and communities" (Kabango 2003). This concern, according to Kabango, takes different shapes, including building homes for the homeless, contributions for medical bills, food for the vulnerable and sharing of seeds as well as increased participation in church activities. With its Christian outlook clearly perceptible in its holistic understanding of development, the RDIS displays a wide variety of projects aimed at the "development of the poorest of the poor". Within this variety, however, a strong focus on the alleviation of poverty and hunger (SDG 1 and 2) is noticeable. 
Our third focal point, the Pentecostal Church of Rwanda (ADEPR), presents again a somewhat different picture. Representative of the fast-growing Pentecostal movement in Rwanda, the ADEPR started in 1940 by the Swedish Free Mission. Today, it claims to have about two million members ${ }^{13}$ and describes itself as a "religious organization with the vision consisting of quantitative and qualitative transformation of the Rwandan Community by Jesus Christ Integral Gospel” (ADEPR Education Ministry). In addition, ADEPR “aims at helping the community to its holistic development" (ADEPR Education Ministry). Development in particular is viewed in terms of education (SDG 4), for which the ADEPR presents itself as "government partner" (ADEPR Education Ministry). By aiming for "education for development" (ADEPR Education Ministry), its concept of development focusses specifically on education issues as a "fundamental human right" (ADEPR Education Ministry) and "a way to achieve development and poverty reduction in Rwanda" (ADEPR Education Ministry). As such, ADEPR is responsible for 80 nursery schools, 158 primary schools, 58 secondary schools, 6 vocational and technical schools and 4 biblical schools. In addition, ADEPR has literacy programmes throughout the country through its chapels $(3,108$ centres). Their literacy programmes PANA (Programme National d'Alphabétisation) was awarded two prizes by the UNESCO in 2001 and 2012. In marked difference to the EPR with its variety of different developmental activities, the ADEPR's focus on development is conceptualized primarily in terms of education (SDG 4), with some developmental concerns relating to health (SDG 3) and empowerment of women (SDG 6). Even though the ADEPR describes itself as a religious organisation, it distinguishes itself from both the EPR and the Anglican Church by using human rights language, which is not found so overtly in the other two FBOs.

The overview of the developmental engagements of three different churches in Rwanda, the EPR, the Anglican Church and the ADEPR, has yielded a mixed picture. While the EPR displays a wide variety of development projects linked to a number of SDGs, the Anglican Church focusses on rural development, in particular on the alleviation of hunger and poverty (SDG 1 and 2). The ADEPR in turn conceives of development primarily in educational terms (SDG 4). All FBOs, however, are united by their focus on holistic development and their perception of development in terms of the church. In contrast to the EPR and the Anglican Church, the ADEPR additionally employs human rights language.

What, then, can be said in terms of these FBOs' relationship to the SDGs? At first glance, the churches' developmental activities by the churches do not seem to differ much from developmental activities by non-faith-based actors. These similarities are also noted by Ware et al. who detect "little observable difference between FBO and NGO activity" (Ware et al. 2016, p. 328), for instance, in the sector of education and health services. Correspondingly, FBO activities directed at "building livelihoods in poor communities" as displayed particularly in the Anglican Church's engagement for the poorest of the poor constitutes "another area of similarity" between FBOs and NGOs (Ware et al. 2016, p. 328). However, despite these similarities, it would be too hasty to conclude that the religious 
actors in Rwanda simply reiterate the developmental norms proclaimed by the SDGs. The relationship is more complex. Rather than merely echoing secular developmental norms, the churches take them up and creatively adapt or transform them. This leads to certain characteristic features of the Rwandan churches with regards to developmental norms that are not necessarily shared by their secular counterparts.

First, the churches tend to view development not as an end in itself, but rather as a means to an end. Bataringaya, for instance, points to church development as the main goal. In a similar way, Kabango believes that "the church holds the key to the real development of life in Rwanda" (Kabango 2003). Development thus becomes a tool in aiming for the implementation of Christian values such as love, hope and peace. This observation is in line with Josephine Sundqvist's assessment of the Pentecostal movement. "The Pentecostal movement has been active in this field [i.e. development] but is has not been their focus" (Sundqvist 2011, p. 170). This must not be misinterpreted, however, as though religious actors considered development to be irrelevant. The contrary is the case as, as evidenced by the different development activities of the religious actors outlined so far in this section.

Second, the religious actors' concern for development is characterized by their holistic perspective. Churches like the Presbyterian Church care for both the individual and their family. They care for both their spiritual and their material needs. The ADEPR phrases this engagement in the terms of "holistic development", echoed by Kabango's "focus on the person as a whole". This difference to nonFBOs is also noted by Ware et al. "FBOs have often been established with holistic emphases embracing both physical and spiritual well-being" (Ware et al. 2016, p. 327). With their emphasis on individual transformation and changed relationships, the churches succeed in engaging their members on a deep and existential level, thereby "build[ing] trust" (Kabango 2003). Heist and Cnaan also consider trust a specific strength of FBOs in comparison with secular NGOs (Heist and Cnaan 2016, p. 5).

We can thus summarize our findings so far by stating that many of the developmental norms as proposed by the SDGs are being taken up by the Christian churches in Rwanda, yet in a way that adapts them creatively and dynamically. As development entrepreneurs, the churches effectively participate in and shape prevalent development concepts (Koehrsen and Heuser 2019 in this volume). By viewing development not as a goal in itself, but in relationship to the church and to their Christian values, Christian churches such as the Anglican, Presbyterian and Pentecostal manage to engage their members in programmes on poverty alleviation, education or health care on a deep, holistic and existential level that government programmes have a hard time attaining. Furthermore, through their focus on transforming behaviour and lasting relationships, they manage to build trust and thereby achieve a high degree of sustainability.

These findings are in line with evidence yielded by other studies exploring the relationship between religious actors and development. With regards to Pentecostal churches, anthropologist Dena Freeman argues that "Pentecostal 
churches are often rather more effective change agents than are development NGOs" (Freeman 2012, p. 3). She gives four reasons for this claim (Freeman 2012, pp. 24-26). (1) Pentecostal churches, contrary to many secular NGOs, are usually self-funded and self-sustainable. The mutual dependency of congregation and church leadership results in a high degree of both accountability and identification of the members with "their" church. (2) "Pentecostal churches focus on transforming individual subjectivities" (Freeman 2012, p. 25). By emphasizing the necessity to be "born again" and to "break with the past", new behavioural patterns are encouraged that are often prerequisite in order to achieve sustainable economic improvement. (3) Not least through numerous weekly activities, Pentecostal churches are rather successful in cultivating participation. Church members are meant to feel "at home" in the "church family", thus regarding the church as an integral part of their identity. Secular NGOs, on the other hand, often remain on the periphery of individual and communal identity. (4) While many secular NGOs ignore the religious fabric of much of African reality, Pentecostalism has found a meaningful way to "relate to the past and to traditional African religions and cultural practices" (Freeman 2012, p. 26). Not only does Pentecostalism incorporate traditional social and cultural forms, it also offers ways to transform them. ${ }^{14}$

Observing the developmental impact of both a church and a secular NGO in a Ugandan village, anthropologist Ben Jones summarizes the differences between faith-based developmental work and that of secular NGOs as follows: In the end, the "work of community development has mostly technical functions and represents an ideological agenda - of rights, empowerment or participation - that had little purchase. In a fundamental way the work of NGOs lacked meaning" (Jones 2012, p. 200). Rather than playing off religious and secular developmental work against each other, it seems that the chances for sustainable development are greatest when both are joining forces, balancing each other's weaknesses by their own respective strengths. It is in their mutual co-operation that "the overall potential for change is phenomenal" (Freeman 2012, p. 26).

So far, we have looked at developmental activities of three different religious actors that can be linked to different SDGs, such as alleviating poverty and hunger or focussing on health and education issues. As such, the projects described need not necessarily be situated in Rwanda, but could be found in any other country undergoing processes of development. The specific history of Rwanda, howeverwith a civil war starting in 1990, culminating in the excess of blood and violence of the 1994 genocide - demands a more contextualized understanding of development. Development in post-genocide Rwanda is inextricably linked to the country's ongoing quest for stability and sustainable peace. Faced with this challenge only one generation after the genocide, when mutual distrust, hate and fear is still prevalent, the quest for stability and security has been turned into a quest for conflict resolution and reconciliation. Again, the significance of Christian churches as major players in Rwanda's civil society and their part in the national reconciliation process, cannot be overestimated. 


\section{"Development and reconciliation go together": 15 Rwandan churches and reconciliation}

In this section, I will explore the churches' roles in Rwanda's process of reconciliation. My key research questions will include how the churches engage in the process and how their efforts in reconciliation is linked to their developmental efforts described above. Again, my approach will be inductive, starting from the analysis of the three different church players, that is, the EPR, the Anglican Church and the ADEPR. Prior to entering into the analysis of the churches, I will give a brief introduction into the concept of reconciliation.

The formerly religiously connoted term reconciliation, has long since become established in historical and political discourse. Linked to the idea of a "new beginning", of stability, safety and (economic) growth after a violent past, the term has been frequently employed by societies in transition. South Africa and the South African Truth and Reconciliation Commission (TRC) is the most wellknown example of this quest (Braun 1999). Yet what exactly is "reconciliation"? While both academics as well as practitioners have pointed to the term's complexity (Leiner and Schliesser 2018), I would like to draw attention to some of its fundamental features that are of particular relevance to the specific context of post-genocide Rwanda. In alignment with theologian Stefanie van de Loo I understand reconciliation as a relational term that refers both to a procedure and a result. It is a "reciprocal process between at least two parties, who in immediate or mediated contact with each other reflect on their mutual relationship, and who aim to design this relationship in a positive and new way by mutual acceptance, as well as the result of this process" (van de Loo 2009, p. 16). ${ }^{16}$ The process of reconciliation may include "different elements such as the confession of guilt, atonement, asking and granting of forgiveness ... up to a newly ordered relationship" (Enns 2013, p. 24).

The relationship aspect as displayed in reconciliation is fundamental to the Rwandan context, which views itself under the perspective of ubuntu, the African concept of community. According to Desmond Tutu, ubuntu "presupposes that we are all connected to one another. Nobody can be a human being by him or herself" (Tutu 2008, p. 12). This means, "my personality is bound up into yours. If I destroy your personality, mine will eventually be destroyed as well" (Tutu 2008, p. 144). Bataringaya summarizes it like this: "To us, social harmony is the 'summum bonum'” (Bataringaya 2012, p. 174).

While the EPR's first mission is to evangelize, its second mission is to "manifest the love of God through the concrete actions of human and social development" (Église presbytérienne au Rwanda (EPR)). These "concrete actions", as represented in the developmental projects described above, are characterized by a common factor, namely reconciliation. As Bataringaya puts it, "development and reconciliation go together. We care for reconciliation. And when reconciliation is an option, people can develop. They can work together, they can, for instance, found a cooperative". ${ }^{17}$ Bataringaya employs the following example to explain the unique situation of Rwanda, "Imagine there is a project in our village and 
everybody should help. We must rebuild parts of a street that the rain had washed away. I come to the place to help. Now I see that Innocence, who is my enemy, is there as well. I cannot bear seeing Innocence. I cannot bear working together with him. I turn around and go. See: No reconciliation, no development". ${ }^{18}$

The close link between development and reconciliation is displayed on several levels within the EPR. I will now turn to addressing the following two levels, pastoral training as well as the individual parishes. In order to equip current and future pastors to lead development and reconciliation programmes in their parishes, the EPR founded the "Centre de formation et de documentation" (CFD) in 1996, shortly after the genocide. The objectives of this centre are, "on one hand, to contribute to the reconstruction of the vitality of religious denominations after the 1994 Genocide tragedy, and, on the other hand, to serve as a cornerstone to the unity and reconciliation process for the people of Rwanda" (cf. Église presbytérienne au Rwanda (EPR)).

As one paradigmatic example on the parish level, we will take a look at the village of Remera. Through the guidance of the local EPR pastor, a trained mediator, a mediation team called the "lights" was assembled that aims at building relationships with perpetrators and with victims. Once these relationships are established, the "lights" aim at fostering links between the perpetrators and victims themselves. While they meet regularly in a group setting to discuss, the "lights" also encourage perpetrators and victims to bond directly by visiting each other. Again, we encounter the developmental aspect as well: perpetrators and victims are supported in establishing small businesses. In the case of the "lights", they have founded a micro loan system that assists perpetrators and victims in growing and selling tree saplings.

A very similar picture emerges when we look at the Anglican Church's engagement in development, which cannot be separated from efforts in reconciliation. In the programme description of the previously discussed Rural Development Interdiocesan Service (RDIS), the following issues are mentioned: "Mobilizing the church, rural development, reconciliation, integral mission" (Kabango 2003). As with the EPR, the church comes first, followed by development and reconciliation. The final point, integral mission seems to sum up the three preceding terms. The inherent connectedness of the three endeavours is exemplified by the list of activities describing the RDIS. "Activities include evangelism, teaching on forgiveness and reconciliation, animal husbandry, food production, micro-enterprise development, fisheries, beekeeping and tree nurseries" (Kabango 2003). This catalogue thus includes evangelistic efforts, conflict resolution endeavours as well as a variety of rural development enterprises. The undifferentiated mixture of these activities demonstrates how all of them are, in the view of the Anglican Church, tied together.

During an interview, Nathan Gasatura, Bishop of the Anglican Church in Butare diocese, situates these efforts of his church into the historical context of the genocide by utilizing the metaphor of a building that had been completely destroyed, with its foundations damaged badly. "Rwanda was like 'Ground Zero'. . . . Morally, spiritually, socially, economically broken to the core. To be able to get a 
nation like Rwanda back on track, you need to re-strengthen the foundation. Peoples' hearts were broken, peoples' trust was betrayed, and to bring a child to ever trust another family again was out of the question" ${ }^{19}$ He then refers to the government's politics of reconciliation, while emphasizing that this policy is not an option to the people, but is rather enforced from above. ${ }^{20}$ "Now the government forces people to live together . . . so this country has had its foundation rebuilt and that is reconciliation" (Kabango 2003). Still within the metaphor of the building, Gasatura then draws the connection between reconciliation and development, "Now the building gets back on its stand; because now reconciliation has happened, development can go. ... Reconciliation and development are inseparable, inextricably connected" (Kabango 2003). With 1 million of Rwanda's total population of 12 million people being members of the Anglican Church, the church's activities in both reconciliation and development work has a substantial impact on people's lives. As one example, Gasatura points to International Prison Ministries, a church-led programme that focusses on bringing victims and perpetrators and their respective families together. There, the aim is to

not only reconcile, but to do projects together, they give them cows together, to feed together, milk the cow together, share the milk together, sell what remains of the milk together, divide the cash together. They would get medical insurances together, build their homes together ... get into cooperatives together, maybe it is rice, maybe it is bee hives, maybe about credit and savings. They also go to church together, celebrate together.

(Kabango 2003)

With both the EPR and the Anglican Church drawing an innate connection between their developmental activities and their efforts in reconciliation, it comes to no surprise that the interdependence of development and reconciliation is found in the work of the ADEPR as well. Consistent with their focus on development as education, they engage in a variety of projects aimed to sensitize and to instruct the population on alternative approaches to conflict resolution, on healing and on reconciliation. "Education has played a great role during the reconciliation process since it has been used to sensitize the Rwandese society to build the skill of living with diversity" (Sundqvist 2011, p. 183). One of the vehicles employed in this endeavour is the radio. While few households in Rwanda own a television, radios are widely popular. During the genocide, the radio had been instrumentalized as a conduit of hate and abuse, serving to incite and radicalize genocidal attitudes and behaviour. RadioTélévision Libre des Mille Collines (RTLM) became synonymous with hate radio. ADEPR now makes use of the popularity of radios for its own purposes that prioritize evangelism, but also emphasize development and reconciliation. By "becoming an important radio announcer by broadcasting a weekly show on the governmental radio" the ADEPR "has also contributed to peace" (Sundqvist 2011, p. 183).

One example of their efforts in facilitating reconciliation, is ADEPR's initiation of a "healing and reconciliation ministry" in 2010 (ADEPR Healing and Reconciliation Ministry). Under the heading of "ADEPR has built unity in Rwandans" 
(ADEPR Healing and Reconciliation Ministry), three different kinds of contributions are meant to help achieve this goal, all based on the Word of God: giving space to share one's feelings, opening room for questions and discussions and arranging for practical help such as "provid[ing] them with shelter, cows and basic materials which they need" (ADEPR Healing and Reconciliation Ministry).Other efforts that display the ADEPR's joint interest in development and reconciliation include reconciliation villages in the Southern parts of Rwanda. In these villages, former perpetrators who had sought refuge in Tanzania live together with survivors affiliated with the ADEPR. Emphasis is placed on communal life as displayed in common projects, similar to the ones described by the EPR and the Anglican Church. Another significant aspect that is found in all three churches is the combination of reconciliation and remembrance activities. Again, we recognize the ADEPR's typical focus on education, even within their reconciliation efforts. "Genocide remembering activities within ADEPR have enabled Christians who have survived the genocide to regain hope and confidence. This has driven those who had dropped out of school to resume schooling" (ADEPR Healing and Reconciliation Ministry).

From this section, focusing on the contributions of religious actors to the country's reconciliation process, a very specific understanding of development has emerged: Development in Rwanda, as it is viewed by the churches, cannot be separated from reconciliation. The churches' emphasis on reconciliation thus takes up a developmental norm as it is displayed by SDG 16, namely to promote peace, justice and strong institutions. The religious actors portrayed here, however, add their own emphasis by focusing on sustainable peace as achieved through reconciliation. As such, the churches both embrace SDG 16 as well as modifying it according to the specific needs of their own context. In more general terms, we might say that the Rwandan churches illustrate how FBOs function as development entrepreneurs, moving as boundary agents between different discursive fields while adapting and conceptualizing development according to their own specific socio-geographical context (Koehrsen and Heuser 2019 in this volume). We will now compare and contrast the specific contributions of the churches to development and reconciliation with those of the Rwandan government.

\section{The Rwandan government and the churches: complementary partners in development and reconciliation?}

A 2005 UN Development Programme report accorded Rwanda the status of "special case" (United Nations Development Programme Report 2015) with regards to achieving the MDGs due to the devastating material and psychological havoc wrecked by the genocide. The trauma of 1994 significantly worsened the complex social and economic problems that had already existed pre-genocide as all MDG indicators were dramatically declining during the genocide, going significantly below the levels achieved in 1990. According to the UNDP report, while many other countries were already quite on track to implement the MDGs during the 1990s, "Rwanda is beginning from behind the 'starting line' in trying to achieve the MDGs" (United Nations Development Programme Report 2015). 


\section{2}

The report furthermore points to the "main challenge for Rwanda", namely, "to stabilize the country through unity and reconciliation" (United Nations Development Programme Report 2015), thus emphasizing the crucial significance of conflict resolution and reconciliation in order to achieve stability in a country uprooted by crime and violence. For without political stability, all developmental activity is doomed to either fail from the beginning or to remain short-lived.

This perception is shared by the current Rwandan government who are well aware that conflict resolution, unity and reconciliation are indispensable prerequisites for effective and sustainable development and socio-economic growth. Businesses will only come to places that are safe and stable. With its ambitious aim to turn Rwanda into Africa's Singapore, the government has turned reconciliation into a political target. By implementing a "National Politics of Reconciliation", it pushes reconciliation on several different levels. On the judicial level, Rwanda revived her traditional judicial courts, gacaca (Friese 2010). ${ }^{21}$ Their far-reaching impact for the societal process of reconciliation and development necessitates a closer look. After the genocide, Rwanda's judicial system broke down. Most judges had been killed; prisons were overcrowded with up to 120,000 people. The International Criminal Tribunal for Rwanda (ICTR) had only limited capacities, so in search for alternatives, Rwanda turned to the gacaca, its traditional courts of alternative justice. From 2001 until their official termination in 2012, there were about 11,000 gacaca courts throughout the country, with respected people serving as lay-judges to preside and to deliver judgments. The establishment of these gacaca courts pursued a number of goals: accelerating the trials, bringing to trial most every person who had participated in the genocide, assigning individual guilt and responsibility, finding the truth, and encouraging a large proportion of the population to participate. The overall goal was less to achieve retributive justice, but rather transformative justice in the sense of reconciliation. The implementation of the gacaca courts was also meant to end a culture of impunity, which had been prevailing in Rwanda for decades, particularly for ethnically motivated crimes. Though not without contestation, when "compared to its alternatives, gacaca should still be judged in a positive light. It is the only feasible and, therefore, the best solution to Rwanda's problems and the legacy of the genocide" (Molenaar 2005, p. 165).

On a national level, Rwanda's "National Unity and Reconciliation Commission" (NURC) was founded, which offers a number of unity and reconciliation projects throughout the country. The ethnic descriptions "Tutsi," "Hutu" and "Twa" were banned by law. Rather, Rwandan unity is now proclaimed by the official motto "We are all Rwandan". Different projects on the communal and individual level were initiated, such as education and sensitization projects and organized encounters between perpetrators and victims.

With a past of division, hatred and terror, unity and reconciliation are being perceived as fundamental to Rwanda's future. They are the "cornerstone to healing and restoring social cohesion among Rwandans," as Fidele Ndayisaba, the Executive Secretary of the NURC emphasizes in a contribution called "Ndi Umunyarwanda ['We are all Rwandan']. Key to healing and human development" 
(Ndayisaba 2016). Ndayisaba believes that "When people trust each other, they feel safe and work together for their better future" (Ndayisaba 2016). This ties in with Bataringaya's picture of people building a street together: people will only work together when there is reconciliation. In a similar vein, Ndayisaba continues: "More specifically, Ndi Umunyarwanda ['We are all Rwandan'] spirit . . has become a bridge to healing and human development" (Ndayisaba 2016). In an analogous manner, John Rucyahana, president of the NURC and a former Anglican bishop, points out during an interview that reconciliation is not only an end in itself, but also a means to an end: "We reconcile for a purpose: for unity, for development, to recreate our dignity, our desire to make a nation, a living hope for this nation". 22 The common quest for development depends on the united efforts of all: "If we unite for development, if we unite for the best of this nation, this does not exclude anybody" (Ndayisaba 2016).

The data so far suggests that the government and the churches are close partners in their common quest for development and reconciliation. The churches emphasize their collaboration with the government in their joint efforts of nationbuilding, unity and stability. "We can say that ADEPR has played a very significant role in building Rwandan society" (ADEPR Healing and Reconciliation Ministry). When asked if there are any differences between government-led and church-led development and reconciliation work, EPR's president Bataringaya emphasizes their similarities. ${ }^{23}$ He points to different health projects to illustrate the close partnership between the churches and the government. Both hospitals of the EPR, for instance, are run jointly by the church and the government. While the church provides the infrastructure and the material, the medical and administrative staff are paid for by the government. Another example of the collaboration of the church with the government is, according to Bataringaya, the co-operation between the government-led NURC and numerous "Unity and Reconciliation Commissions" (URCs) on the local level throughout the country and also within the churches. In the case of the Presbyterian Church, there is a local URC within each of its 7 presbyteries as well as in each of its 162 congregations. This tight net of URCs accounts for the fact that the strategies employed and the emphases set are nearly identical throughout the country. On a regular basis, the NURC meets with URCs on a semi-local and local level to ensure the quality of their cooperation. As one example of the close collaboration between the churches and the government, Bataringaya points to the country's annual "Week of Commemoration", held each year in April in to commemorate the genocide. The preparation for this week is done jointly by the NURC and the different URCs throughout the country.

The close collaboration then begs the question whether there are any differences at all between the government and religious actors with regard to the different reconciliation projects. And the answer is, yes, indeed, there are. While there are similarities on the strategical and pragmatic level, a look at the content reveals significant differences between government-led and church-led initiatives. After stating their similarities, Bataringaya continues: "It [i.e. reconciliation] is not easier when you are a Christian. But: Christians have the word of God. This is 
a big help. The pastor and the church can play a great role in healing. It is better if you have the word of God to find the way for bringing people together and help them for reconciliation. This is hope and the way to healing, to reconciliation and to life". This is hope". ${ }^{24}$ Bataringaya also points to other helpful options of secular conflict transformation work such as psycho-social therapy or trauma counselling, yet highlights the main differences between secular and religious reconciliation work: "The power by the word of God that the church possesses. This is missed by the state. The churches have something special. They walk with the people, with the perpetrators, with the victims. People feel that they are not alone. This is lacking in the government. But they complement each other". ${ }^{25}$ With the government employing a political and target-oriented conception of reconciliation, that is, aiming towards national unity and development, the churches add a more personal dimension that stresses relationship building. As they "walk with" the people, they impart a sense of community, support, trust and hope.

A closer look at the example of Remera, mentioned above, helps to illuminate further the difference between religious actors and government actors. In the village of Remera, we recall, the EPR has established a group of trained mediators, the "lights", that work together with perpetrators and victims. In Remera, reconciliation activities go hand in hand with developmental projects such as micro loans and small farm projects. What at first glance might look like one of the government organized victim - perpetrator villages, shows some distinct features that underline its Christian nature. In particular, three aspects serve to highlight the specificities of this Christian reconciliation and developmental project.

First, the Christian message of individual transformation, of breaking with the past, of healing and of forgiveness provides helpful resources. The normative implications following from this message are relayed through weekly sermons, group activities such as youth groups, bible study groups or women's groups as well as through worship. Connected to sermons, group activities and worship is a second valuable aspect: while public expressions of pain and suffering are not acceptable in society in general, the sphere of religion is an exception to this rule. In church services, for instance, through the medium of song and dance, traumatized victims have a chance to express their emotions, a first step towards healing. Third, there are additional church activities and services such as Christian-based seminars offered on healing and trauma counselling or trained mediators. Mixed strategies are employed that combine the insights of non-faith-based mediation with the resources of the Christian faith, set in the familiar context of the church setting in the home village.

To sum up, we have seen that on the one hand the churches view themselves as close partners of the government in terms of joint developmental and reconciliation efforts. Not least due to their close collaboration and regular planning meetings, the churches' and the government's activities display strong similarities in terms of strategy and pragmatic implementation. For instance, the joint care of a cow as a means to facilitate encounters between perpetrators and victims is a common project of both the government and different churches. On the other hand, to view the churches as simply echoing the government would entail a reductive perspective, 
as the churches supplement the government in important ways. With its tight net and its top-down strategies, the government manages to reach into every corner of the country. At the same time, some criticism of this kind of enforced reconciliation "from above" has been voiced as it tends to achieve mere "outer", "formal" reconciliation as opposed to "inner", "authentic" reconciliation. Complementing the government's top-down strategies, the churches provide bottom-up reconciliation strategies from within civil society, including grassroots activities, needed to achieve sustainable peace (Abu-Nimer 2001) through healing and forgiveness what Jacques Derrida calls the "exceptional and extraordinary, standing the test of the impossible" (Derrida 2000, p. 12). From this analysis thus emerges a clearer picture of how churches as FBOs act as boundary agents, moving effectively between the established lines of secular and religious organisations and in different development contexts and discourses (Koehrsen and Heuser 2019 in this volume).

In order to better understand the distinct contribution of religious actors such as churches, Marc Granovetter's differentiation between strong-tie and weak-tie communities continues to be helpful (Granovetter 1973). Strong-tie groups refer to communities that are rather closed. Examples of strong-tie groups are found in devoutly religious groups, a small village or members of a specialized academic discipline. Weak-tie communities, on the other hand, are made up of people that are loosely connected, for instance, through social media networks. While strongtie groups offer emotional support and meaning to their members, they tend to be resistant to change and new ideas. Weak-tie groups may offer less support, yet they allow for greater mobility and access in terms of ideas and influence. Religious communities are often considered strong-tie communities. This makes them resistant to new ideas. On the other hand, once new ideas have entered the group, for instance, through trusted and influential individuals such as pastors, the potential for change throughout the group is substantial. In a post-genocidal context such as Rwanda, conflict resolution and reconciliation processes are nothing less than paradigm shifts in thinking and behaviour. For these to occur, the strength and coherence of strong-tie communities such as churches is needed (Gopin 2009, p. 78). ${ }^{26}$ For the "transformation of human relationships can only be achieved by actors outside the government and therefore a multilevel peace process always must include social movements on the local scene" (Sundqvist 2011, p. 164). For ground-shifting societal processes - such as development and reconciliation after a genocide - to occur, the collaboration of weak-tie governmental actors and strong-tie religious actors is needed.

\section{Conclusion}

We began this chapter by looking at the specific context of Rwanda. Literally burnt to ashes in a devastating civil war that culminated in the 1994 genocide, Rwanda lay in ruins; its survivors traumatized. Development in Rwanda, according to the UN, had been set back by years. Yet recent years have seen a remarkable change as an economic miracle has started to take hold of the country, with positive sideeffects for most of the population. Many developmentally relevant figures testify 
to a change for the better: life expectancy is increasing, children and mother mortality is declining nationwide health insurance was installed, primary school education was made mandatory. In many respects, Rwanda is clearly thriving although the human rights situation in this country has not been improving in an equal manner. Nevertheless, Rwanda's progress is all the more remarkable considering that neighbouring countries such as Burundi or the DR Congo with similarly violent histories had started off better on the Human Development Index in 1990 than Rwanda, yet had already been overtaken by Rwanda in the year 2000.

Of the many factors contributing to Rwanda's development, this chapter looked at two in particular: the roles of Rwanda's religious actors, especially churches, and the role of Rwanda's emphasis on reconciliation. Due to Rwanda being a largely Christian nation, we looked at three different Christian denominations, the Presbyterians, Anglicans and Pentecostals and their conception of development and reconciliation. Finally, we compared the churches' understanding and approaches to development and reconciliation with those of the Rwandan government. The results can be summarized under the following three aspects.

\section{"Holistic development"}

For all three churches, development is of crucial significance. All three churches are actively engaged in a variety of development activities, with church-specific emphases. As such, the churches' developmental activities tie in with a number of developmental norms as put forward by the SDGs. The EPR was seen to display the broadest range of activities, linking to a number of SDGs. The Anglican Church's development programme Rural Development Interdiocesan Service (RDIS) focusses on the development of the poorest of the poor (SDG 1 and SDG 2 ), while the ADEPR views development through the particular lens of education (SDG 4). Despite the variety of developmental activities displayed by the churches, two characteristics serve to unite them. First, the religious actors analysed do not view development as an end in itself to be pursued, but rather as a means to an end. Secondary goals such as contributing to the development and unity of the country are subordinated to the prime goal: "to build a strong church" (EPR). Second, all three churches are united in their quest for "holistic development". Holistic development understands development as going beyond mere material progress and to include the spiritual and the material, the individual and the communal dimensions.

\section{"Development and reconciliation go together"}

From my analysis, a very specific contextualized understanding of development has emerged. In a national discursive field that stresses reconciliation, development becomes a question of reconciliation. FBOs that engage in Rwanda relate to these discourses by combining development and reconciliation. All three churches point to reconciliation as the sister of development. Given Rwanda's excessively violent history on the one hand and its cultural emphasis on ubuntu, that is, on 
community, on the other hand, development acquires here a strong social dimension. Any long-term developmental success will depend on the sustainability of peace as brought about by reconciliation. The analytical distinction between reconciliation and development thus seems to be on the verge of collapsing in this particular context, especially when it comes to the level of practical application. Whether the joint care for a cow in a certain instance is in theory primarily for reconciliation purposes or for developmental purposes, appears in practice to be of secondary significance.

\section{Churches and government as "complementary partners"}

My analysis has shown the churches to view themselves as partners of the Rwandan government's national politics of reconciliation as well as of the national quest for development. Churches continuously emphasise their role as supporters of the government through references on their official websites praising their credit in contributing to the nation's unity (ADEPR Education Ministry) and, not least, through direct collaboration with the government itself. Churches co-operate with the government in developmental and reconciliation activities such as the joint management of hospitals or the collaborative design of the nation's annual week of commemoration of the genocide. Despite their joint activities, however, the churches do not simply echo the government. Rather, FBOs have their own approach to reconciliation work. They act as development entrepreneurs by focussing on bottom-up projects and new reconciliation techniques by bringing in the religious dimension of reconciliation (e.g. the Christian message of love and forgiveness) (Koehrsen and Heuser 2019 in this volume). While the churches thereby show themselves to be competent boundary agents, frequently crossing the lines between secular and religious spheres and connecting different discursive fields, this rarely includes any criticism of the government. Critical utterances against the government are remarkably absent in the churches' discourses. Rather than as outspoken critics, the churches act in way of supplementation. Where the NURC's president Rucyahana emphasizes, "We reconcile for a purpose: for unity, for development, to recreate our dignity, our desire to make a nation". ${ }^{27}$ the churches add, they develop and reconcile "to build a strong church whose Christians are spiritually mature, able to testify God's kingdom in the world and whose social environment is fully bloomed". ${ }^{28}$

\section{Notes}

1 I thank Jens Koehrsen for his helpful suggestions in the final draft of this contribution.

2 Roméo Dallaire, commander of the UNAMIR-forces stationed in Rwanda during the genocide, recounts in this book his experiences during the genocide and points to the failure of the world community, which could have stopped the killings (Dallaire 2004).

3 Even the overall positive Credit Suisse report points to the current challenges to democratic values in Rwanda, while at the same time highlighting the government's achievements: "The Rwandan government offers its citizens peace, safety, a relatively high level of economic freedom and a steadily improving quality of life. The price is 
strict political control and a taboo surrounding discussion of sensitive topics like ethnicity" (Amman 2015, p. 43).

4 While this term is here taken from the Pentecostal Church of Rwanda (ADEPR) homepage, the Presbyterian Church of Rwanda (EPR) and the Anglican Church employ it as well (cf.).

5 For a detailed treatment of religio-scapes in the specific context of the prosperity gospel cf. Heuser (2015).

6 In recent scholarship, the term FBO (faith-based organisation) has been more frequently used than the term FBN (faith-based non-governmental organisation).

7 Some churches, however, seem to focus exclusively on proselytization with no or little concern for development as Narayan et al. (1999). These are often found in small highly evangelical circles.

8 While Ware et al. do not even mention local churches as FBOs engaged in development work, Heist and Cnaan acknowledge their relevance yet state that "we do not cover in-country organizations that strive for social and economic development such as local churches or local denominations" (Heist and Cnaan 2016, p. 2).

On a side note, Heist and Cnaan draw a comparison between FBOs and welfare services provided by churches in their native USA. "Our findings, so far, suggest that faith-based international social and economic development is similar to welfare services provided by congregations in the USA" (Heist and Cnaan 2016, p. 14). This paper can be viewed as the attempt to draw out to the comparison in order to include local churches in developing countries as agents of development.

9 Interview with Pascal Bataringaya. President of the Presbyterian Church of Rwanda. Kigali, 21 February 2016

10 The following details are based on an interview with the President of the EPR, Pascal Bataringaya. Cf. the homepage of the EPR.

11 The United Evangelical Mission (UEM) is rooted in three different mission organisations: the Rhenish Mission (since 1828), the Bethel Mission (since 1886) and the Zaire Mission. In 1996, it became an international communion of churches, with all its partner churches enjoying equal status. While UEM headquarters are in Wuppertal, Germany, there are regional offices in Africa (Dar es Salaam, Tanzania) and Asia (Medan, Indonesia). UEM employs about 120 co-workers. UEM places particular significance on diaconia, HIV and AIDS, the rights of women and children, scholarships, development cooperation, intercultural meetings and project support. (Vereinte Evangelische Mission).

12 John Wesley Kabango is now the head of the office for African affairs at the UEM.

13 Manooks, Kwizera, administrative staff member of the ADEPR (1 October 2016).

14 Much of what Freeman points out with regards to Pentecostal churches can be applied to other Christian denominations as well. For an assessment of the specific strengths of FBOs in development work cf. Heist and Cnaan (2016). They point to the trust in faithbased organisations by the addressees, FBOs' helpful networks, religious volunteers, funding and the share of the faith community. At the same time, they indicate some weaknesses such as FBOs' inclination to proselytize, their tendency to work alone and avoid co-operation and religion's role in contributing to religious violence (Heist and Cnaan 2016, p. 4).

15 Interview with Pascal Bataringaya.

16 My emphasis.

17 Interview with Pascal Bataringaya.

18 Interview with Pascal Bataringaya.

19 Interview with Nathan Gasatura. Bishop of the Anglican Church. Butare Diocese. Butare (Rwanda), 23 February 2016.

20 Gasatura hints at the restrictive political climate of his country. These restrictions are noticeable throughout civil society, for instance, regarding freedom of the press 
and freedom of political opposition. In 2014, the World Press Freedom 2014 Index of Reporters Without Borders ranked Rwanda 162nd of 180 countries. As Susan Thomson points out, "international and domestic human rights organizations regularly accused the RPF government of harassment and intimidation of its political opponents and journalists" (Thomson 2015, p. 325).

21 [ga'tfatfa]. The Kinyarwanda term means "grass" and refers to the place in the village where the traditional gacaca courts take place. For a detailed treatment of the gacaca courts cf. Friese (2010, pp. 59-72).

22 Interview with John Rucyahana, President of the National Unity and Reconciliation Commission (NURC), Kigali/Rwanda, 26 February 2016.

23 Interview with Pascal Bataringaya.

24 Interview with Pascal Bataringaya.

25 Interview with Pascal Bataringaya.

26 At the same time, strong ties serve as boundary markers and can thus serve to create and enhance already existing or newly formed boundaries, in this case, centered around religious identities.

27 Interview with John Rucyahana.

28 Église presbytérienne au Rwanda (EPR).

\section{References}

Abu-Nimer, M., 2001. Reconciliation, Justice, and Coexistence: Theory and Practice. Oxford: Lexington Books.

ADEPR Education Ministry [online]. Available from: http://en.adepr.rw/spip.php?article61 [Accessed 1 February 2019].

ADEPR Healing and Reconciliation Ministry [online]. Available from: http://en.adepr.rw/ spip.php?article59 [Accessed 1 February 2019].

ADEPR Home [online]. Available from: http://en.adepr.rw [Accessed 1 February 2019].

Amman, D., 2015. A Country of Hope. Africa. Rise of a Continent. Credit Suisse Bulletin, 3, 30-45.

Anglican Communion Rwanda [online]. Available from: www.anglicancommunion. org/structures/member-churches/member-church.aspx?church=rwanda [Accessed 1 February 2019].

Bataringaya, P., 2012. Versöhnung nach dem Genozid: Impulse der Friedensethik Dietrich Bonhoeffers für Kirche und Gesellschaft in Ruanda. Kamen: Spenner.

Bouka, Y., 2018. Rwanda. In: A. Mehler, et al., eds. Africa Yearbook. Leiden: BRILL.

Braun, J., 1999. Versöhnung braucht Wahrheit. Der Bericht der südafrikanischen Wahrheitskommission. Gütersloh: Chr. Kaiser Gütersloher Verlagshaus.

Dallaire, R., 2004. Shake Hands with the Devil. The Failure of Humanity in Rwanda. London: Arrow.

Derrida, J., 2000. Jahrhundert der Vergebung. Verzeihen ohne Macht - unbedingt und jenseits der Souveränität. Lettre International, 48, 10-18.

Dicklitch, S., and Rice, H., 2004. The Mennonite Central Committee (MCC) and FaithBased NGO Aid to Africa. Development in Practice, 14 (5), 660-672.

Église presbytérienne au Rwanda (EPRa). Historical Background [online]. Available from: http://cfd.epr.rw/index.php/en/cfdhome/historical-background [Accessed 1 February 2019].

Église presbytérienne au Rwanda (EPRb). Vision and Mission [online]. Available from: www.epr.rw/index.php/en/about-us/vision-and-mission [Accessed 1 February 2019]. 
Église presbytérienne au Rwanda (EPR), 2016. Gitarama Newsletter [online]. Available from: http://cfd.epr.rw/index.php/en/cfdhome/historical-background [Accessed 1 February 2019].

Enns, F., 2013. Transformative Gerechtigkeit als Möglichkeitsraum zur Versöhnung. Kirchliche Zeitgeschichte, 26 (1), 23-35.

Freeman, D., 2012. The Pentecostal Ethic and the Spirit of Development. In: D. Freeman, ed. Pentecostalism and Development. Churches, NGOs and Social Change in Africa. Basingstoke: Palgrave Macmillan, 1-38.

Friedli, R., 2000. Der ethnopolitische Konflikt in Rwanda. In: R. Moser, ed. Die Bedeutung des Ethnischen im Zeitalter der Globalisierung. Einbindungen. Ausgrenzungen. Säuberungen. Bern: Paul Haupt, 133-149.

Friese, S., 2010. Politik der gesellschaftlichen Versöhnung. Eine theologisch-ethische Untersuchung am Beispiel der Gacaca-Gerichte in Ruanda. Stuttgart: Kohlhammer.

Gopin, M., 2009. To Make the Earth Whole. The Art of Citizen Diplomacy in an Age of Religious Militancy. New York, NY: Rowman \& Littlefield Publishers.

Granovetter, M., 1973. The Strength of Weak Ties. American Journal of Sociology, 78 (1), $1360-1380$.

Gupta, L., 1998. Follow Up Survey of Rwandan Children's Reaction to War Related Violence from 1994 Genocide. New York, NY: United Nations Press.

Heist, D., and Cnaan, R.A., 2016. Faith-Based International Development Work: A Review. Religion, 7 (19), 1-17.

Heuser, A., ed., 2015. Pastures of Plenty. Tracing Religio-Scapes of Prosperity Gospel in Africa and Beyond. Frankfurt am Main: Peter Lang.

Jones, B., 2012. Pentecostalism, Development NGOs and Meaning in Eastern Uganda. In: D. Freeman, ed. Pentecostalism and Development. Churches, NGOs and Social Change in Africa. Basingstoke: Palgrave Macmillan, 181-202.

Kabango, J.W., 2003. Church Based Rural Development [online]. Available from: www. micahnetwork.org/library/church/church-based-rural-development-rdis-rwanda-johnwesley-kabango [Accessed 1 February 2019].

Koehrsen, J., and Heuser, A., 2019. Beyond Established Boundaries: FBOs as Developmental Entrepreneurs. In: J. Koehrsen and A. Heuser, eds. Faith Based Organisations in Development Discourses and Practice. London: Routledge.

Leiner, M., and Schliesser, C., 2018. Alternative Approaches in Conflict Resolution. London: Palgrave Macmillan.

Molenaar, A., 2005. Gacaca, Grassroots Justice After Genocide. The Key to Reconciliation in Rwanda? Leiden: African Studies Centre.

Narayan, D., et al., 1999. Voices of the Poor: Can Anyone Hear Us? Washington, DC: World Bank Publications.

National Institute of Statistics of Rwanda, 2014. Socio-Cultural Characteristics of the Population [online]. Available from: www.statistics.gov.rw/publication/rphc4-thematicreport-socio-cultural-characteristics-population [Accessed 1 February 2019].

Ndayisaba, F., 2016. Ndi Umunyarwanda. Key to Healing and Human Development [online]. Available from: www.nurc.gov.rw/index.php?id=75\&tx_ttnews[tt_news] $=143$ $\& \mathrm{cHash}=678 \mathrm{e} 51 \mathrm{ca} 5784 \mathrm{e} 3 \mathrm{~d} 3 \mathrm{~b} 1 \mathrm{e} 7440 \mathrm{bfcf5b} 725$ [Accessed 1 February 2019].

Sundqvist, J., 2011. Reconciliation as a Societal Process. A Case Study on the Role of the Pentecostal Movement (ADEPR) as an Actor in the Reconciliation Process in PostGenocide Rwanda. Svensk Missionstidsskrift, 99 (2), 157-195.

Thomson, S., 2015. Rwanda. In: S. Elischer, et al., eds. Africa Yearbook. Politics, Economy and Society South of the Sahara in 2014. Leiden, Boston: BRILL, 323-334. 
Tutu, D., 2008. Versöhnung: Sei wahr und werde frei. Freiburg: Herder.

United Nations Development Programme. Trends in the Human Development Index: 1990 2014 [online]. Available from: http://hdr.undp.org/en/composite/trends\#a [Accessed 1 February 2019].

United Nations Development Programme, 2018. Human Development Indices and Indicators 2018 Statistical Update [online]. Available from: http://hdr.undp.org/sites/default/ files/2018_human_development_statistical_update.pdf [Accessed 1 February 2019].

United Nations Development Programme Report, 2015. Human Development Report 2015 [online]. Available from: www.unrwanda.org/undp/mdg.htm [Accessed 1 February 2019].

van de Loo, S., 2009. Versöhnungsarbeit. Kriterien - theologischer Rahmen-Praxisperspektiven. Stuttgart: W. Kohlhammer Verlag.

Vereinte Evangelische Mission. Who We Are [online]. Available from: www.vemission.org/ en/about-uem/who-we-areuem-film.html [Accessed 1 February 2019].

Ware, V.-A., Ware, A., and Clarke, M., 2016. Domains of Faith Impact: How "Faith" Is Perceived to Shape Faith-Based International Development Organisations. Development in Practice, 26 (3), 321-333. 


\section{Index}

Adloff, Frank 130

Adventist Development and Relief Agency

(ADRA) 3, 9, 22, 116, 117, 118, 120, $121,128,131$

advocacy $12,22,25,38,57,58,65$;

for children's development $93-96$;

Evangelical development NGOs 65 -66; and justice $72-75$; Micah Challenge 16, $68-72$; non-political 75-76; as religious action $77-79$; transformational 77-78

'Amplifying the voices of children' $103-104$

Anglican Church: development work 144; role in Rwanda's reconciliation $149-150$

Annan, Kofi 66

Australia: and integral mission $64-65$; Jubilee 2000 campaign 68,80

Ban Ki-moon 96, 99

Baptist World Aid 65

Basel Mission 30, 31, 39, 49; Farming

Centre $40-46$; history $33,34,35$;

individual conversions $33-34$; volunteer work 33; see also Mission 21

Bataringaya, Pascal 143, 146, 148

Berger, Julia 11, 15

Birch, Charles 35

Birim, Isom 41

Blumhardt, Christoph Gottlieb 50

boundary agents $3,7-8,17$; Mission 21 as 51; World Vision 87

Bretton Woods 5

Byworth, Justin 90

Carey, George 5

Carey, William 59

Carrette, Jeremy 16

categorising FBOs $11-12,13$
Catholic Church: of Guyana 129; in Rwanda 142

Centre for Religion, Economy and Politics, "Religion and Development in the Global South" 3

challenging power structures $132-133$

"chameleon politics" 16

charismatic theology of advocacy $77-79$

charitable work 23, 49; clothing (re-)

distributions 113; in the Hindu

religion 132

child-focused SDGs 104-107

ChildFund International 88

children's development, World Vision's advocacy at the UN 93-96

'Children speak out on the Sustainable Development Goals' 106

Christian Children's Fund (CCF) 88-89

Christian FBOs 2, 6, 25; and gender conservatism 10; proselytism 9-10; see also faith-based development organisations (FBOs); missionary organisations; Protestant FBOs

Christianity $38,42,51$; evangelical 57 , 142 ; in Guyana $122-123,132$; and Hinduism 115; in Rwanda 139-140, $140-141,147,154-155$; spirituality 120

churches 11, 12, 30, 38-39; Anglican $145,149-150$; denominations 12 ; Église presbytérienne au Rwanda (EPR) 14, 23, 143, 143 -144, 148-149, 154; Evangelical Church of Kalimantan 41; as FBOs 142; in Guyana 123, 124; in Indonesia 40, $46-47$; partnerships with government 151-155, 157; Pentecostal Church of Rwanda (ADEPR) 145, 150-151, 153; in Rwanda 140, $154-155$; 
Seventh Day Adventist 22, 114, 115; as stakeholders of social development 48-49; World Council of Churches (WCC) 35-37; see also Anglican Church; Église presbytérienne au Rwanda (EPR); faith-based development organisations (FBOs); missionary organisations; Pentecostal Church of Rwanda (ADEPR)

Clarke, G. 17

climate change 8

clothing (re-)distributions 113

Cnaan, R. A. 89, 142, 144

community-based development 32,63 , 121 -122; ubuntu 148, 156-157

comparison: of FBOs and NGOs 8-9; of

Protestant and non-Protestant FBOs 25 conversion 51

Cooperation of Evangelical Missions (KEM) 34

critical reflection on development 18

\section{denominations 12}

Derrida, Jacques 155

development 10, 12, 22, 25, 31, 45, 114, $117,140,142,151$; and charitable work 49; church 146; communitybased 32, 63, 121-122; critical reflection 18; ecumenical approaches 35-37; and FBOs 6-7; gift exchange theory 129-131; in the Global South 90-91; Global Strategy for Women's, Children's and Adolescents' Health 96, 98-100; and good governance 129; holistic 17, 23, 48-49, 117, 117-121, 133-134, 143, 144, 156; human 36, 48-49, 94-95; human dimension 18, 19; international 94; in Kalimantan 44; and leadership 127-129; materialistic 33, 36, 42, 118 ; and missionary work 33 ; nationbuilding 124-127; and reconciliation 140, 156-157; and religion 58, 116; in Rwanda 23; social 143; spiritual 9, 38, 42, 94-95, 119, 120; and spirituality $5,18,32$; state-organised 4; stewardship 129; transformational $20,21,90$

developmental entrepreneurship 1, 3, $17-18,31,50,58$ development studies, religious turn 2 dharma 113

diaconia $31,33,50$

Dicklitch, Susan 142 discourses 7, 13-14; and "chameleon politics" 16; religious discursive fields of FBOs $15-16,17$

dispensationalism 59, $62-63$

diversity: of FBOs 11; of Protestant FBOs 2

Economic and Social Council (ECOSOC) 4,87

ecumenical movement 12, 30, 48, 60; and development 35 -37; Missio Dei 37

education 48; Farming Centre 45; theological 39

Edwards, Joel 68, 69; Just Mercy 72-73, 76

Église presbytérienne au Rwanda (EPR) 143, 154, 156; development work 143-144; role in Rwanda's reconciliation $148-149$

embeddedness, of FBOs 4, 8-9, 15, 16, $17-18,22,25$

Emerson, Jim 104, 105

"Empowerment of Basic Groups" 31, 37, $46,47,48$

Escobar, Samuel 19, 60, 61

ethnic identification in Guyana 126-127

ethno-politicization 114, 117, $124-127$

ethno-religious identities $121-123,124$

evangelical FBOs 9, 12, 13, 20; and gender conservatism 10; integral mission 57; Micah Challenge 2, 12 , 15, 16, 18, 19, 57, 58; Mission 21 12, 19, 20; proselytism 9-10; stakeholders 9-10; World Vision 2; see also Micah Challenge

Evangelicalism 58; advocacy $65-66$; advocacy as religious action $77-79$; in the Global South 60; integral mission 60, 61, 62 -63, 64; Jubilee 2000 campaign 66,67 ; justice $72-75$; Lausanne Covenant 61; Micah Challenge 68-72; non-governmental organisations (NGOs) 61; progressive 60; relief and development NGOs 61; 'social gospel' 59-60; theology 61; transformational development 63; in the United States 59, 65; Wheaton statement 61-62; William Wilberforce 59; see also Micah Challenge

evangelical Protestantism 2, 142

evangelisation 50

Evidence Summit 1

faith-based development organisations (FBOs) 1, 2, 5, 6, 10, 12, 19, 21, 25, 51, 87, 88, 94, 106, 114, 142, 151; Adventist 
Development and Relief Agency (ADRA) 3, 9, 22, 116, 117; as boundary agents 7-8, 17; categorising $11-12,13$; challenging power structures $132-133$; "chameleon politics" 16; Christian FBOs 6; churches as 142; comparison with NGOs 8--9, 10; defining 7-8, 10, 11; denominations 12; and development $6-7$; development agendas 14 ; developmental entrepreneurship 3, $17-18,31$; discourses $7,13,15,19$; diversity of 11 ; embeddedness $4,8-9$, $15,16,17-18,22,25$; evangelical 13; flexibility of 14 ; and gender conservatism 10; Global Partnership to End Violence Against Children 100-103; Global Strategy for Women's, Children's and Adolescents' Health 96, 98 -100; in Guyana 23; holistic development $117-121$; Micah Challenge 2; Mission 218 -9; Muslim 6, 9; and non-governmental organisations 115-116, 147; proselytism 9, 10, 22, 32, 116, 132; Protestant 2, 12; public funding 89 -90; reconciliation work 23-24; relationship to SDGs 145 -146; religious discursive fields 15-16, 17; Save Abee Foundation (SAF) 16, 22, 113, 114, 116, 120, 128; spiritual development 94 -95; stewardship 129; United Evangelical Mission (UEM) 144; work in SDGs 14; World Vision 2, 8, 14, 16, 18, 21, 22, 63, 86; see also churches; missionary organisations; Protestant FBOs

faith-driven humanitarianism, characteristics of 91

Farming Centre 31, 37, 38 -39, 48, 49; boarding school 43; and development 45; Sekolah Penyambung Lidah 43, 44; Training Centre 42, 43

Finney, Charles 59

Flach, Gustav 41, 42, 43

flexibility of FBOs 14

Freeman, Dena 19, 21, 146

Friedli, Richard 140

gacaca 152

Gasatura, Nathan 149 - 150

gender conservatism 10

gift exchange theory $129-131$; rejecting a gift 133

Global Movement for Children in Latin America and the Caribbean 105-106

Global Partnership to End Violence Against Children 100-103
Global South: development 90 -91; Evangelicalism in 60; Global Strategy for Women's, Children's and Adolescents' Health 96, 98-100

Global Strategy for Women's and Children's Health 21

Global Strategy for Women's, Children's and Adolescents' Health 98-100

good governance 121, 129

Granger, David $121-122$

Granovetter, Mark 155

Guyana 17, 113, 116; Adventist Development and Relief Agency (ADRA) 22, 116-117; Africans 125 -126; Catholic Church 129; Christianity in $122-123,132$; churches 123, 124; communitybased development $121-122$; development in 127-129; Economic Recovery Programme 128; ethnopoliticization 114, $124-127$; ethnoreligious identities $121-123,124$; FBOs 23; and holistic development $118-121,133-134$; Ministry of Social Cohesion 121; nation-building 124-127; 'politricks' 128; religion's role in development 121; Save Abee Foundation (SAF) 16, 22, 116, 128, 131; see also Adventist Development and Relief Agency (ADRA); Save Abee Foundation (SAF)

Halstead, Narmala 130

Haynes, Jeffrey 21

Heist, D. 89, 142, 144

Henry, Carl, The Uneasy Conscience of Fundamentalism 60

Hinduism 22, 114, 115, 125, 132, 133; and charitable work 132; dharma 113; karma 118, 130; pandits 120 ; reincarnation 119

history: of Basel Mission 33, 34, 35; of World Vision 87-88

Hoelkedoer, Tena 87

Hoffman, Claudia 11, 19, 21

holistic development 17, 23, 48-49, 117, $133-134,143,144,156$

Hopgood, S. 90

Howard, Peter 91

Hoyte, Desmond 128

human development 18, 19, 36, 94 -95; churches as stakeholders of $48-49$

Human Development Index (HDI) 139,156

Hutu 140 
identity-forming organisations $46-47$

Indonesia 51; churches 40, 46 -47; Dayak people 45; Farming Centre 40-46, 48; identity-forming organisations $46-47$; and Islam 40; Jokowi 40; Kalimantan 40; Pancasila 40; Tumbang Lahang 41 integral mission 20, 57, 60, 61, 64; community-based development 63 ; and redemption 62, 63; Wheaton statement 61-62; World Vision 63

integrity of Creation 37

International Monetary Fund (IMF) 5, 94 international non-governmental organisations (INGOs) 86, 87, 94, 106; Global Partnership to End Violence Against Children 100-103; Global Strategy for Women's, Children's and Adolescents' Health 96, 98-100

invisible NGOs 31 ; missionary organisations as $31-33$

Islam, in Indonesia 40

Islamic Relief 8, 88, 93

Jenkins, Kevin 91, 99

Jokowi 40

Jones, Ben 147

Jubilee 2000 campaign 66, 66 -67, 80; in Australia 68; in the United Kingdom $66-67$

justice $35,37,57,58,72-75$, 76; see also social justice

Justice, Peace, Integrity of Creation (JPIC) $35-36$

Kabango, J. W. 144

Kalimantan 31, 39, 40, 49, 50, 51; Dayak people 45; development in 44; Farming Centre 40-46, 49; see also Farming Centre

karma 118, 130

Ketuhanan Yang Maha Esa 40

Kirsch, Jochen 39

Kloß, Sinah 7, 22, 24

Kowalski, R. 130

Ladd, George Eldon 62

Lausanne Covenant 20, 61

leadership, and development 127-129

liberation theology 20,36, 60

Mahin, Marko 48

mainline Protestant FBOs 12

Mao Zedong 31

materialistic development 33, 36, 42, 118,119
Mau, Steffan 130

Mauss, Marcel 130

Micah Challenge 2, 12, 15, 16, 18, 19 , $57,58,66,68-72,81$; advocacy as religious action 77-79; in Australia 80; Jesus Agenda DVD 79; justice 72-75; mobilisation $79-80$; non-political advocacy $75-76$; publications 72,74

Micah Declaration on Integral Mission 64 Micah Network 20, 63, 80

Millennium Development Goals (MDGs) 4, 5, 7, 8, 14, 20, 21, 30, 57, 68, 92, 94, 95; Micah Challenge 68-72; Rwanda as "special case" $151-152$

MinistryWatch.com 88-89, 108-109n2 Missio Dei 33, 37

Mission 21 2, 8-9, 12, 19, 20, 30, 33, 34, 50 ; advocacy work 38 ; as boundary agents 51; and development $48-49$; as developmental entrepreneurs 50; development work $38-39,51$; "Empowerment of Basic Groups" 31, 37, 46, 47, 48; Farming Centre 31, $37,38-39,40-46,48-49$; grants 39 ; principles of development work $37-39$; theology 50

missionary organisations $11,12,30$, 31, 50, 132; Basel Mission 31, 33, 34, 35; Cooperation of Evangelical Missions (KEM) 34; and development 33; development work 32; as invisible NGOs $31-33$; and spirituality 51 ; volunteering 32, 51

Muggeridge, Eric 89

Muslim FBOs 6, 9; Islamic Relief 93; proselytism $9-10$

Myers, Bryant, Walking with the Poor 63

Nagahire, Odile 143

National Association of Evangelicals 61 nation-building $124-127$

Ndayisaba, Fidele 152 - 153

Nirvana Humanitarian Society (NHS) 114,132

non-governmental organisations (NGOs) 4, 21, 32, 39, 57, 65-66, 80, 87, 94, 114, 127; Christian 90 -92; comparison with FBOs 8 -9, 10; and faith-based organisations 115-116, 147; as "givers" 23; Global Partnership to End Violence Against Children 100-103; Global Strategy for Women's, Children's and Adolescents' Health 96, 98-100; invisible $31,31-33$ non-orthodox Protestantism 3 


\section{Index}

non-political advocacy $75-76$

nutrition: and holistic development

118 -121; and Seventh Day

Adventism 115

Oke, Femi 105

othering 9, 122

Ott, Craig 31

Padilla, René 19, 60, 61, 63

Palestine, World Vision's development work in 92

Pancasila 40

pandits 120

Parry, Jonathan 130

'pathfinders' 101

peace 35,37

Pelkmans, M. 9

Pentecostal Church of Rwanda (ADEPR) $145,147,153$; development work 145 ; role in Rwanda's reconciliation $150-151$

Pierce, Robert 87

pietism 33,34

'politricks' 128

postsecular environment $86-87$

pre-millennial dispensationalism $62-63$

Presbyterian Church of Rwanda 14, 17, 23

proselytism 9, 10, 22, 32, 42, 91, 116, 132,142

Protestant FBOs 2, 12; comparison with other FBOs 25; discourses 13 -14; Mission 21 2; see also evangelical FBOs

Protestantism 2; evangelical 2; nonorthodox 3; pietism 33, 34; 'social gospel' 59-60

quasi-secular organisations 15

Rand, Stephen 66, 69, 73

reciprocal relationships 129

reconciliation $23-24,140,147,152$; and development 156 - 157; in Rwanda, role of the church in $148-151$

redemption 62,63

reincarnation 119

religion: and development 116; role in development 121

religious agency 1

religious discursive fields of FBOs 17; and "chameleon politics" 16; Save Abee

Foundation 16

religious NGOs (RNGOs) 11, 12 "rice Christians" 9

Rice, Heather 142

Rucyahana, John 153

Rural Development Interdiocesan Service (RDIS) $144-145,149$

Rwanda 23, 156; ADEPR 145, 146, 147 , 150-151, 153; Anglican Church 144, 149 -150; Catholic Church in 142; Christian churches 140, $140-141$; Église presbytérienne au Rwanda (EPR) 143, 144, 148 -149, 154; gacaca 152; genocide 141, 147; government partnerships with churches $151-155$, 157; Human Development Index Value (HDIV) 139, 141; implementation of MDGs 151 - 152; National Unity and Reconciliation Commission (NURC) 152-153; reconciliation 24; reconciliation process, role of the church in $148-151,152-153$; Seventh Day Adventist Church 142; social groups 140; Unity and Reconciliation Commissions (URCs) 153

Saminarsih, Diah 105

Save Abee Foundation (SAF) 16, 22, 113, $114,116,120,128,131$

Save the Children 88

Schärer, Hans 43

Schliesser, Christine 7, 11, 23, 24

Sekolah Penyambung Lidah 43, 44

Seventh Day Adventist Church 9, 22, 114, $115,118,123,128$; and nutrition 115 ; in Rwanda 142

Shelenz, Laura 92

side events 87, 103 -107; 'Amplifying the voices of children' 103-104;

'Children speak out on the Sustainable Development Goals' 106; 'A World without Violence against Children' $104-105$

Sider, R. J. 13, 15

social development 143; churches as stakeholders of $48-49$

'social gospel' 59-60

social justice 60

social transformation $49-50$

spiritual development 5, 38, 42, 94 -95, 119,120

spirituality $32,51,115,120$

stakeholders: of evangelical FBOs 9-10; in social development $48-49$

stewardship 129 
Strauss, Stephen 31

strong-tie communities 155

structural adjustment programmes (SAPs)

94, 95; see also development

Sundqvist, Josephine 146

sustainable development 1, 35

Sustainable Development Goals (SDGs)

$5-6,8,14,23,31,51,92,94,100$,

$106,143,151,156$; child-focused

goals $104-107$; relationship to FBOs

$145-146$

Swiss Agency for Development and Cooperation (SDC) 19, 39

Tearfund 63, $64-65,65,66,67,69$

theological education 39

theology: of advocacy $77-79$;

dispensationalism $59,62-63$; of integral mission $61-65$; of justice $72-75$; see also Evangelicalism

Thomas, Clive 126

Training Centre 42, 43

transformational advocacy $77-78$

transformational development 20,21, 57, $61-62,63,90$; see also integral mission

Trust and Reconciliation Commission (TRC) 148

Tumbang Lahang: Farming Centre 31, 38, $40-45$

Turner, Cathy 101

Tutsi 140

Tutu, Desmond 148

Twa 140

ubuntu 148, 156-157

UN Convention on the Rights of the Child 92

United Evangelical Mission (UEM) 144

United Kingdom: Evangelical relief and development NGOs 61; and integral mission 64; Jubilee 2000 campaign 66-67; Tearfund 65, 66

United Nations (UN) 2, 21, 86, 96; Agenda 2030 1, 5, 6; Economic and Social Council (ECOSOC) 4; FBOs 94; Global Partnership to End Violence Against Children 100 -103; Global Strategy for Women's and Children's Health 18, 21; Global Strategy for Women's, Children's and Adolescents' Health 98 -100; Millennium Development Goals (MDGs) 4, 5, 7, 8, 14, 20, 21, $30,57,68,92,151-152$; and the postsecular environment 87; "Religion and Sustainable Development: Building Partnerships to End Extreme Poverty" 1; religious NGOs (RNGOs) 11; side events $87,103-107$; structural adjustment programmes (SAPs) 94, 95; Sustainable Development Goals (SDGs) 4, 5-6, 8, 14, 21, 23, 31, 92, 100, 143, 151, 156; World Vision 22; see also World Vision

United States: Evangelicalism in 59; Evangelical relief and development NGOs 61

Unity and Reconciliation Commissions (URCs) 153

Unruh, H. R. 13, 15

U.S. Agency for International Development 1

van de Loo, Stefanie 148

Ver Beek, Kurt Allen 32

Vineyard Movement 60

Vinjamuri, L. 90

Vischer-Mylius, Mattheus 49

volunteering 32, 33, 51, 128, 131, 133; clothing (re-)distributions 113, 114

Ware, V.-A. 17

weak-tie communities 155

welfare services $11-12$

Wesley, John 59

Wheaton statement $61-62$

White, Jade $87-88$

Widodo, Joko see Jokowi

Wolfensohn, James D. 5

World Bank 1, 5, 94

World Council of Churches (WCC) 5, 9, 18, 19, 35, 94; Climate Change Programme 35 -36; development policy $36-37$; globalisation programme 36 ; Justice, Peace, Integrity of Creation (JPIC) $35-36$

World Evangelical Alliance (WEA) 69, 71

World Faiths Development Dialogue (WFDD) 5

World Vision 2, 8, 14, 16, 18, 21, 22, 63, $86,108,109$ n11; advocacy for children's development 93 -96; 'Children speak out on the Sustainable Development Goals' 106; commitment to the Global Strategy for Women's, Children's and Adolescents' Health 96, 98-100; history $87-88$; motivations and approach for 


\section{Index}

development work 87-89, 90-93; policy statement on advocacy 65 ; public funding $89-90$; side events at the United Nations $103-107$; strategies at international fora 96; Voices of the Poor 95; work in Palestine 92; work in SDGs 14; work with child-focused agencies $88-89$
'World We Want' initiative 106

'World without Violence against Children, A' 104-105

Yousafzai, Malala 104

Zimmermann, Christoph 43 